\title{
OPORTUNIDADES Y RETOS EN LA FORMACIÓN, INVESTIGACIÓN Y APLICACIÓN DEL CONOCIMIENTO BIBLIOTECOLÓGICO
}

COORDINADORES:

Jaime Ríos Ortega

César Augusto Ramírez Velázquez 


\section{La presente obra está bajo una licencia de:}

\section{http://creativecommons.org/licenses/by-nc-sa/3.0/deed.es MX}

\section{Atribución-No Comercial-Licenciamiento Reciproco 3.0 Unported}

Eres libre de:

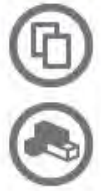

copiar, distribuir y comunicar públicamente la obra

hacer obras derivadas

Bajo las condiciones siguientes:

Atribución - Debes reconocer la autoría de la obra en los términos

especificados por el propio autor o licenciante.

No comercial - No puedes utilizar esta obra para fines comerciales.

Licenciamiento Recíproco - Si alteras, transformas o creas una obra a

partir de esta obra, solo podrás distribuir la obra resultante bajo una licencia

igual a ésta.

\section{Esto es un resumen fácilmente legible del: texto legal (de la licencia completa)}

En los casos que sea usada la presente obra, deben respetarse los términos especificados en esta licencia.
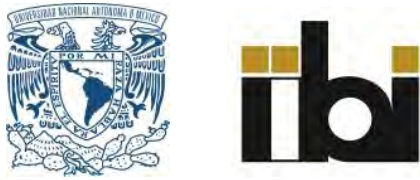
Oportunidades y retos en la formación, investigación y aplicación del conocimiento bibliotecológico 


\section{COLECCIÓN}

Sistemas Bibliotecarios de Información y Sociedad

Instituto de Investigaciones Bibliotecológicas y de la Información 
Oportunidades y retos en la formación, investigación $y$ aplicación del conocimiento bibliotecológico

\author{
Coordinadores \\ Jaime Ríos Ortega \\ César Augusto Ramírez Velázquez
}

Universidad Nacional Autónoma de México 2012 
Z669.7

O66 Oportunidades y retos en la formación, investigación y aplicación del conocimiento bibliotecológico / compiladores, Jaime Ríos Ortega, César Augusto Ramírez Velázquez. - México : unam, Instituto de Investigaciones Bibliotecológicas y de la Información, 2012.

209 p. - (Sistemas bibliotecarios de información y sociedad)

ISBN: 978-607-02-3703-4

1. Investigación Bibliotecológica - Tendencias - Conferencias

2. Enseñanza de la Bibliotecología - Tendencias - Conferencias

I. Ríos Ortega, Jaime, compilador II. Ramírez Velázquez, César Augusto, compilador III. ser.

Diseño de portada: Mario Ocampo Chávez

Imagen de portada: Salvador Mendoza López

Primera edición 2012

D.R. (C) Universidad NaCional Autónoma de MÉxico

Ciudad Universitaria, 04510, México, D.F.

Impreso y hecho en México

ISBN: 978-607-02-3703-4 


\section{Contenido}

SOCIEDADES BASADAS EN EL CONOCIMIENTO Y EN

LOS PROCESOS DE FORMACIÓN DE REDES . . . . . . . . . . . . . . . . . . .

Rosalba Casas-Guerrero

El Diplomado en Administración y Preservación

de Archivos Digitales del CUIB . . . . . . . . . . . . . . . . . .

Juan Voutssas

Perspectivas del patrimonio artístico en México . . . . . . . . . . . . 45

Renato González Mello

RETOS DE LA FORMACiÓN BIBLIOTECOLÓGICA EN LA SOCIEDAD RED . . . . . . . 59 Hugo Alberto Figueroa Alcántara

LA EXPERIENCIA EN LA FORMACIÓN DE POSGRADO

en ARChivística en Colombia . . . . . . . . . . . . . . . . . . . . .

Ruth Helena Vallejo

LA INVESTIGACIÓN BIBLIOTECOLÓGICA SOBRE COMUNIDADES INDÍGENAS . . . .

César Augusto Ramírez Velázquez

Metodología PARA la ENSEÑANZa Y EL APRENDiZAJE EN MATERIA DE ESTUdiOS DE USUARIOS DE INFORMACIÓN . . . . . . . . . . . Isabel Villaseñor Rodríguez

OBJETIVOS E PERSPECTIVAS DA INVESTIGAÇÃO BIBLIOTECÁRIA

NA SOCIEDADE DA INFORMAÇÃO . . . . . . . . . . . . . . . . . . . . . 111

Emir José Suaiden

RETOS EN LA INVESTIGACIÓN DE LA PRODUCCIÓN EDITORIAL EN El MEDIO DIGITAL . . . . . . . . . . . . . . . . . . . . . 117 Georgina Araceli Torres Vargas 
Bibliografía: la RAigambre humanista de la Bibliotecología . . . . . . . 129 Héctor Guillermo Alfaro López

Contribución del Centro de Investigación y Desarrollo en Tecnologías del Conocimiento (CIDTEC) a la formación E INVESTIGACIÓN BIBLIOTECOLÓGICA . . . . . . . . . . . . . . . . . . . 143 Johann Pirela Morillo

EL CINE COMO DOCUMENTO INFORMATIVO PARA LA DOCENCIA Y LA INVESTIGACIÓN (CON ESPECIAL REFERENCIA A LOS ESTUDIOS DE DERECHO Y CINE). . . . . . . . 155 Juan Antonio Gómez García

LAS COMPETENCIAS EN EDUCACIÓN BIBLIOTECOLÓGICA: MITOS Y REALIDADES . . . 173 Rosa María Martínez Rider

Fomentar LA LECTURA A TRAVÉS DE LA PUBLICIDAD EN LIBRERÍAS Y EDITORIALES: EL MODELO GANDHI . . . . . . . . . . . . . . . 187 Juan Carlos Marcos Recio

LAS DIMENSIONES DE LOS DATOS: UNA COMBINACIÓN DE TRADICIONES BIBLIOGRÁFICAS Y OPORTUNIDADES DE CAMBIO . . . . . . . . . . . . . . . 209 Ariel Alejandro Rodríguez García 


\title{
Sociedades basadas en el conocimiento y en los procesos de formación de redes
}

\author{
Rosalba Casas-Guerrero \\ Instituto de Investigaciones Sociales, UNAM
}

\section{INTRODUCCIÓN}

$\checkmark$ e ha difundido ampliamente la idea de que el conocimiento $\longrightarrow$ es factor estratégico para el crecimiento integral y el bienes- tar social de los países, así como para favorecer el desarrollo sustentable, proteger y mejorar el medio ambiente y fomentar la competitividad. Sin embargo, esta idea ha sido difundida por muy diversas organizaciones y se utiliza actualmente prácticamente en todos los discursos políticos. La idea de sociedades basadas en el conocimiento está perdiendo ímpetu en la esfera académica, al menos entre algunos sectores, que son sumamente críticos de este concepto. Lo anterior implica un reto para los académicos dedicados a esta reflexión y consiste en darle sustento y significado a ésta más allá de los discursos oficiales.

Por lo tanto es necesario discutir ¿cuál debe ser la racionalidad sobre la que se construya lo que se ha denominado sociedades basadas en el conocimiento para lograr los objetivos estratégicos antes mencionados?

Este ejercicio de reflexión implica varios aspectos que ameritan discusión: 
a) El primero se refiere a la diferenciación entre sociedades de la información y sociedades del conocimiento, términos que actualmente se utilizan indistintamente. Esto implica diferenciar entre información y conocimiento, asunto que no es sencillo. En términos generales podemos argumentar que la sociedad de la información sería aquélla que tiene la capacidad de prestar servicios de telecomunicaciones a bajo costo y acceso generalizado a todos los usuarios, la infraestructura computacional y su accesibilidad para poner a disposición de la población la información que circula en la red de redes. Aquí estamos hablando específicamente de acceso a la tecnología y a la información, lo que no implica la apropiación ni el uso del conocimiento.

b) Otro aspecto a destacar en esta reflexión es que en la mayor parte de los documentos producidos en el marco de organismos internacionales y también en estudios sobre procesos de innovación tecnológica, se ha puesto el énfasis en el concepto de una "economía del conocimiento", más que en la idea de sociedades basadas en el conocimiento. Esto se debe al énfasis en el tema del impacto del conocimiento relacionado con la competitividad de los países, como un indicador central en la evaluación del grado de desarrollo económico alcanzado. El conocimiento se expresa más nítidamente en repercusiones en cuanto a la productividad y la competitividad de los países, asunto que es innegable y del cual tenemos innumerables ejemplos en los países del norte, así como en los denominados países de industrialización reciente. No obstante, como se ha argumentado ampliamente, el crecimiento no genera automáticamente desarrollo social, ni bienestar. Las repercusiones de esas actividades se aprecian de forma tangible e intangible en el corto y mediano plazos en indicadores de tipo económico. En tanto que los beneficios sociales, tales como una más adecuada provisión de bienes públicos, una mejor calidad del aire y del agua, mayor atención educacional, mejoras en la salud y la nutrición y una expansión del acceso a infraestructura esencial, tanto para los grupos más pobres como para otros grupos sociales, parecerían ser más bien efectos indirectos y observables en el largo plazo, y además ser fuertemente depen- 
dientes del sistema educativo, del grado de equidad de éste y de las características de la política social. Tal como lo ha planteado el Club de Roma: "Por lo anterior, un segundo argumento en esta exposición es que el desarrollo tecnológico, por sí mismo, no es un factor equivalente a sociedades basadas en conocimiento, en la acepción que queremos defender".

c) Un tercer argumento de importancia para esta reflexión y que amerita una nueva comprensión es que el conocimiento es valioso no solamente en términos económicos, sino porque genera bienestar para los grupos sociales que se han apropiado de éste y contribuye a la solución de necesidades básicas. Es así como uno de los retos en la construcción de sociedades basadas en conocimiento es poner este recurso al servicio del desarrollo social, y garantizar que se genere una apropiación social. Se requiere pensar de manera prioritaria en el conocimiento, no como un bien económico sino como una forma de abordar la solución de problemas básicos, de contribuir a la integración de los grupos marginados y de preservar la multiculturalidad que caracteriza a nuestra población.

d) Un cuarto argumento para definir la concepción de sociedades basadas en el conocimiento es que la solución de los problemas de orden socioeconómico prioritario para mejorar la calidad de vida de la población, requiere un mayor acceso al conocimiento y una mejor distribución social del mismo. En un país con altos niveles de pobreza, como México, el conocimiento, la ciencia, la tecnología y la innovación deben contribuir al mejoramiento de las necesidades básicas de alimentación, salud, vivienda, educación, empleo, medio ambiente y energía reutilizable, entre otros aspectos. Por lo tanto una sociedad basada en el conocimiento se caracterizará por la producción y el uso del conocimiento equitativamente distribuido.

e) Un quinto aspecto sustantivo sobre la naturaleza de estas sociedades es un proceso social más participativo acerca de las decisiones relativas al conocimiento; es decir, procesos deliberativos y la posibilidad de que los distintos sectores que participan en la toma de decisiones y en los procesos deliberativos, lo hagan con 
conocimiento del tema o problema que se afronta y sean capaces de hacer valer sus posiciones.

Como lo ha afirmado López Cerezo (2007),

En el mundo contemporáneo, especialmente en los países desarrollados, la sociedad civil ha cobrado un protagonismo que no tenía en el pasado, ya sea a través del activismo espontáneo o estructurado mediante grupos de interés (organizaciones ecologistas, asociaciones de consumidores, grupos afectados, etc.). Hoy encontramos una diversidad de actores que pugnan en la arena política de la distribución de bienes, impactos negativos y riesgos, incluido el recurso del conocimiento y los efectos adversos de la innovación. Por lo tanto, la sociedad del conocimiento será algo real cuando la sociedad civil y los distintos grupos sociales tengan la capacidad para tomar decisiones, construir argumentos o generar propuestas sustentados en conocimiento.

Sin embargo el optimismo inicial acerca de las potencialidades democráticas del conocimiento se ha ido diluyendo. Se pensaba inicialmente que el conocimiento era infinitamente ampliable. Su uso no lo desgasta sino que, al contrario, puede producir más conocimiento. No obstante, como lo ha sostenido Toffler (1990:13), para que esta situación sea así, en el caso de los países en desarrollo se necesita formar a la población para que use el conocimiento disponible, situación que entra en debate con el argumento que sostiene que para construir una sociedad basada en el conocimiento es necesario formar a la población para producir conocimiento. Algunos estudios en este campo han puesto de relieve que formar para el uso del conocimiento podría ser más equitativo que formar para la producción de conocimiento.

¿EN QUÉ TIPOS DE CONOCIMIENTO SE ESTÁ PENSANDO AL HABLAR DE SOCIEDADES BASADAS EN EL CONOCIMIENTO?

Éste no se reduce solamente al científico, tecnológico e intelectual. El concepto de conocimiento es muy amplio, y en la concepción 
sobre sociedades basadas en el conocimiento es importante tener esto en cuenta, porque hasta muy recientemente se pensó que únicamente la ciencia podría hacer contribuciones originales a esta forma de sociedad. Sin embargo, se requiere rescatar y revalorar otros tipos de conocimiento que son sustantivos para construir una sociedad basada en el conocimiento, sobre todo para el caso de nuestros países:

a) Cabe también mencionar el conocimiento tradicional o basado en la experiencia y generado y acumulado por diversos grupos sociales. Es fundamental considerar los saberes y prácticas tradicionales para pensar en la solución de problemas básicos en el país, y para evitar destruir valores y patrones culturales que pudieran ser afectados con la introducción de nuevo conocimiento, tecnologías o innovaciones. Con una concepción de este tipo se estaría orientando la construcción de una sociedad basada en conocimiento, que considerara la diversidad cultural que es tan importante para nuestro país.

b) Asimismo es importante rescatar y revalorar el conocimiento generado y usado por las organizaciones, que ha mostrado ser esencial para los procesos productivos. Tal conocimiento tiene un carácter colectivo (que no resulta de la simple suma de piezas de conocimiento), que ha requerido de la comunicación e interacción así como del aprendizaje entre distintos agentes para su generación y transmisión.

A pesar de que el conocimiento puede ser clasificado típicamente en conocimiento popular y conocimiento erudito, diversos autores hacen referencia a que el conocimiento que importa para la construcción de sociedades basadas en el conocimiento (SBC) es el erudito, y que éste es producido tradicional y generalmente en las universidades, instituciones de investigación y otros lugares académicos, incluyendo bibliotecas, laboratorios, seminarios y conferencias, todo lo cual puede también ser descrito como "conocimiento basado en la investigación”. No obstante, la perspectiva de conocimiento en los países en desarrollo parecería ser distinta e incluiría también el conocimiento denominado popular. Por lo que 
Oportunidades y retos en la formación, investigación y aplicación...

tendríamos al menos tres tipos de conocimiento indispensables para la construcción de sociedades sustentadas en este recurso: el científico y tecnológico, el tradicional y el que se genera en las organizaciones.

\section{¿QUÉ OTROS RECURSOS SON NECESARIOS PARA TRANSITAR}

A SOCIEDADES BASADAS EN EL CONOCIMIENTO?

La Unesco (2003) y otros autores consideran varias características que desde mi perspectiva son muy sugerentes, sobre todo para países de Iberoamérica, y que se refieren a tres tipos de capacidades que es importante generar a la par del conocimiento:

a) la capacidad creativa para generar conocimiento nuevo;

b) la capacidad para usar el conocimiento que ya existe o el nuevo, y

c) la capacidad para determinar la relevancia del conocimiento para necesidades específicas que varían de acuerdo al tipo de la sociedad de que se trate.

En el caso de México, pese a ser éste un país que tiene capacidad creativa y que ha generado conocimiento científico, tecnológico, tradicional y organizacional, no nos hemos caracterizado por desarrollar capacidades para usar el conocimiento que ya existe, ni para determinar su relevancia para atender necesidades específicas. Es decir, nuestras capacidades de conocimiento, en general, se encuentran subutilizadas o almacenadas y no han sido socialmente movilizadas.

Lo anterior nos lleva a argumentar que la sola existencia de conocimiento no garantizará su impacto en la sociedad, a menos que los distintos agentes involucrados en su generación y uso tengan la capacidad para movilizarlo y definir su relevancia social y económica con base en la concreción de objetivos y acciones, priorizando los sectores de actuación de acuerdo con objetivos de desarrollo.

También hay otros aspectos que definen las posibilidades de construcción de sociedades basadas en conocimiento y que son 
esenciales: la equidad educativa, el acceso público a la información, los derechos culturales y humanos, la diversidad cultural y lingüística, y la libertad de expresión.

En esta misma línea de argumentación, Chaparro (2001) sostiene que hay cuatro aspectos o procesos fundamentales que caracterizan a este tipo de sociedades (sBc):

a) El primero es la educación como un proceso más crítico que asegure el desarrollo de sociedades dinámicas, y que tenga la capacidad de responder al nuevo entorno y de construir su futuro. Aquí el autor hace referencia a una educación con capacidad para desarrollar creatividad en el personal y en la sociedad a través de la maduración de la capacidad analítica y de comprensión en el niño, futuro ciudadano y profesional. Es decir, se estaría planteando la idea de una educación orientada a "aprender a aprender";

b) el segundo aspecto sería el desarrollo de procesos de apropiación social del conocimiento, por actores o sectores específicos de la sociedad. Esta apropiación se tendría que dar por parte de individuos, de organizaciones (como es el caso de las empresas), o de la comunidad y de las instituciones básicas de la sociedad. Sólo a través de dicho proceso el conocimiento se convierte en "bien público" que al acumularse e interrelacionarse pasa a formar parte del capital social con el que cuenta una organización, una comunidad, una institución social, una empresa, o la sociedad misma;

c) un tercer factor importante, que constituiría una de las principales dimensiones de las sociedades del conocimiento, serían los procesos de aprendizaje social, por medio de los cuales el conocimiento crea o fortalece capacidades y habilidades en las personas, comunidades y organizaciones que se lo apropian. Entendido de esta forma, el aprendizaje es el proceso fundamental que lleva del conocimiento a su uso, la transformación, la innovación y el cambio social. El aprendizaje puede ser visto como un proceso de educación continua que crea, a su vez, el nuevo conocimiento. La capacidad de generar procesos dinámicos de aprendizaje social a nivel de una organización, de la comunidad, 
Oportunidades y retos en la formación, investigación y aplicación...

o de instituciones sociales básicas, es el elemento más crítico para pensar en sociedades del conocimiento, y

d) el último rasgo importante de las sociedades y de las organizaciones del conocimiento, sugerido por Chaparro, es el desarrollo de un pensamiento estratégico y prospectivo, necesario para comprender los cambios que se están produciendo en el entorno, proyectar tendencias dinámicas, e identificar aspectos críticos o estratégicos que permitan orientar los esfuerzos que se realizan en el proceso de generación de conocimiento y de cambio social o desarrollo organizacional, en una dirección adecuada. Este último factor facilita el uso del conocimiento como motor de desarrollo y como instrumento crítico en el proceso de "construcción de sociedad", (Chaparro, 2001: 22).

Considerando los cuatro elementos sugeridos por Chaparro y el énfasis que pone en lo que otros han llamado sociedades del aprendizaje, pensando en el caso de México lo podríamos caracterizar de la siguiente forma:

a) Como un sistema educativo nacional que no ha logrado generar un acceso universal, además de que no ha estado enfocado a la construcción de capacidades para responder al entorno, ni para construir nuevas estrategias sociales. Este factor es una fuerte limitante de las capacidades de creatividad y análisis por parte de todos los grupos sociales, e impide la apropiación social del conocimiento y por ende dificulta el cambio social;

b) como una sociedad capaz de generar conocimiento pero que no basa su desarrollo en este recurso. Tenemos capacidades de conocimiento científico y tecnológico acumuladas principalmente en las universidades y centros públicos de investigación; y comunidades y grupos culturales locales que poseen una riqueza sustantiva basada en sus conocimientos tradicionales, pero que no han rescatado sus procesos de aprendizaje social a lo largo del tiempo; empresas que han logrado la generación de conocimiento internamente y acumulado procesos de aprendizaje, pero que no lo han empleado como elemento sustantivo en la construcción de sus capacidades organizacionales y tecnológicas y, 
c) como un país que no ha construido un pensamiento estratégico para aprovechar sus capacidades y sus procesos de aprendizaje en beneficio del desarrollo social.

De acuerdo con las ideas anteriormente expresadas referidas a la definición de lo que deberían ser las sociedades basadas en el conocimiento y a las capacidades y recursos que se necesitan para construirlas, hay muchos retos que vencer, por lo que se podría argumentar que en cierta forma este concepto es una especie de tipo ideal de sociedad o, como lo diría Vaccarezza (2007), un proyecto a futuro, en donde los efectos sociales del conocimiento no son directos, ni automáticos, ni lineales.

\section{Una Visión del CONOCimiento desde América Latina}

La idea de que el conocimiento, la ciencia, la tecnología y la innovación son factores clave para el desarrollo echa sus raíces en América Latina durante los años sesenta y setenta, en una etapa en la que se consolidaba la teoría de la dependencia como explicación del subdesarrollo y se transitaba por un modelo económico basado en la sustitución de importaciones. El pensamiento y las concepciones que se generaron en esa época han sido denominadas por diversos autores como el Pensamiento Latinoamericano en Ciencia, Tecnología y Sociedad (PLACTS), cuyos exponentes principales, entre otros, fueron: en Argentina Amílcar Herrera; ${ }^{1}$ Jorge Sábato, ${ }^{2}$

1 Entre sus principales publicaciones relevantes en este campo, cabe mencionar: Ciencia y Politica en América Latina, Siglo XXI, México, 1971; "Social determinants of science policy in Latin America: explicit science policy and implicit science policy", The Journal of Development Studies, v. 9, núm. 1, 1972, pp. 19-37; Catastrophe or New Society?: A Latin American World Model, IDRC, Ottawa, 1976; La Larga Jornada: la crisis nuclear y el destino biológico del hombre, Siglo XXI, México, 1981; Las Nuevas Tecnologías y el Futuro de América Latina, Siglo XXI, México, 1994.

2 Entre sus principales publicaciones: El pensamiento latinoamericano en ciencia, tecnología y desarrollo-dependencia, Paidós, Buenos Aires, 1975, y junto con Michael Mackenzie, La producción de tecnología: autónoma o transnacional, ILET/ Nueva Imagen, México, 1982. 
y Oscar Varsavsky; ${ }^{3}$ José Leite Lópes en Brasil; Miguel Wionsczek, ${ }^{4}$ en México; Osvaldo Sunkel, en Chile; Francisco Sagasti, en Perú; 5 Máximo Halty Carrere, en Uruguay y Marcel Roche, en Venezuela. Este pensamiento se sustentó en el interés por explicar el atraso de la ciencia y la tecnología, que fue interpretado en un ámbito histórico-cultural sobre el desarrollo. En los años sesenta la preocupación sobre cómo acoplar la infraestructura científico-tecnológica a la estructura productiva de la sociedad constituyó una de las expresiones más claras de esta corriente de pensamiento (Dagnino et al., 1996: 21); se desechó la versión dominante en esa época sobre el proceso lineal y acumulativo del desarrollo, es decir que el subdesarrollo no era una etapa previa del desarrollo; la ciencia fue considerada como una expresión relevante de la dependencia cultural; se sostenía que la solución de los problemas de la ciencia y la tecnología no se lograba con la transferencia de modelos institucionales ni con los recursos de los países desarrollados, como lo postulaban en la época los organismos internacionales y como lo aceptaban los gobiernos locales.

3 Entre sus principales publicaciones cabe mencionar: Ciencia, política y cientificismo, Centro Editor de América Latina, Buenos Aires, 1969; Proyectos Nacionales: planteo y estudios de viabilidad, Ediciones Periferia, Buenos Aires, 1971; Hacia una Política Científica Nacional, Ediciones Periferia, Buenos Aires, 1972; Estilos Tecnológicos: propuestas para la selección de tecnologías bajo racionalidad socialista, Ediciones Periferia, Buenos Aires, 1974; Marco histórico constructivo para los estilos sociales, proyectos nacionales y sus estrategias, Centro Editor, Buenos Aires, 1975.

4 Son de mencionarse las siguientes publicaciones: "La transferencia internacional de tecnología: El caso de México", en F.C.E., 1974; "La planeación de la ciencia y la tecnología en México”, en Comercio Exterior (México), vol. 26, núm. 11, noviembre, 1976, pp. 1272-1276; “¿Es viable una política de ciencia y tecnología para México?”, Foro Internacional, vol. XX, núm 81, julio-septiembre, México.

5 Entre sus principales publicaciones pueden mencionarse las siguientes: $E l$ desarrollo científico y tecnológico en América Latina, BID/ INTAL, Buenos Aires, 1974; Tecnología, Planificación y Desarrollo autónomo, Instituto de Estudios Peruanos, Lima, 1974; Ciencia, Tecnología y Desarrollo Latinoamericano, F.C.E., México, 1980; La Política Científica y Tecnológica en América Latina: Un estudio del Enfoque de Sistemas, El Colegio de México, México, 1983; Crisis, Knowledge and Development, GRADE, Lima, 1985. 
En su versión más radical este pensamiento llamaba al cambio revolucionario. Sin embargo en su versión menos contestataria se exigía la adopción por parte del Estado de políticas que impulsaran "las interrelaciones dinámicas entre los distintos actores pertenecientes a la sociedad, marco en el cual se formuló la idea del Triángulo de Sábato". ${ }^{6}$ El PLACTS criticó el modelo lineal de generación de conocimiento e innovación, mucho antes que éste fuera cuestionado en los países desarrollados. La importancia de este pensamiento radicó en que fue una visión autónoma de la región que tenía un fuerte contenido social en los planteamientos para el desarrollo de ciencia y tecnología, y por tanto centraba la discusión en la relación ciencia, tecnología y sociedad, y no solamente con los sectores productivos.

Una de las ideas planteadas por Amílcar Herrera en el marco de PLACTS y que resulta muy sugerente para la discusión en esta mesa se refiere a la diferencia que él planteaba entre la capacidad de innovación tecnológica y la capacidad social de innovación. La primera "es la capacidad de crear una solución para un problema técnico específico del aparato productivo"; en tanto que la segunda se refiere a la "capacidad global de una sociedad para incorporar el progreso tecnológico en función de su propia concepción de desarrollo", (Herrera, 1983). Esta idea que desde mi perspectiva sigue siendo vigente en el contexto actual nos llama a pensar en dos aspectos cruciales: uno es el de la concepción de desarrollo en el marco de un proceso de globalización, y el otro es cómo orientar las capacidades de conocimiento, de tecnología y de innovación

6 La idea expresada por Sábato y Botana (1968) en el concepto conocido como el "Triángulo de Sábato" tenía como objetivo alertar a América Latina sobre el papel crucial de la ciencia y la tecnología para el desarrollo y la armonía que tendría que haber entre los tres actores, las universidades, los sectores productivos y el gobierno, que constituían los tres ápices del triángulo. La concepción del "Triángulo de Sábato" estaba orientada a la promoción del desarrollo tecnológico en América Latina para salir de nuestra situación de dependencia. Esta idea antecedió por varias décadas a la ahora en boga de la "Triple Hélice", generada por académicos de países del Norte, (ver Etzkowitz, 1994). 
acumuladas, hacia objetivos que hagan compatible el desarrollo económico con el social.

Con la fuerte crisis que en los años ochenta afectó a las sociedades latinoamericanas y con el agotamiento del modelo de sustitución de importaciones y la inestabilidad política en varios países de la región, las ideas generadas como parte de PLACTS perdieron vigencia.

No obstante, como lo han documentado varios estudios, durante y después de la crisis, en los años ochenta y noventa, algunas empresas de la región latinoamericana y de México lograron generar importantes procesos de aprendizaje tecnológico, (Katz, 1986, 1987; Vera-Cruz, 2003). Es decir, a pesar de la situación de subdesarrollo y dependencia de nuestros países, se ha documentado el desarrollo de procesos de aprendizaje, acumulación de capacidades tecnológicas y procesos de innovación en algunos sectores productivos. ${ }^{7}$ Como se ha sostenido más arriba los procesos de aprendizaje son fundamentales en la construcción de sociedades basadas en el conocimiento y estos se dan de manera permanente en distintos tipos de organizaciones, por lo que hay un proceso continuo de generación y uso del conocimiento.

Estos hallazgos marcaron una ruptura con la idea de que el atraso tecnológico y la transferencia tecnológica del exterior habían hecho imposible la generación de acumulación de capacidades de conocimiento propias. Diversos estudios han mostrado que los cambios en el contexto económico y político, nacional e internacional, y el proceso de globalización en el que se sitúan los países latinoamericanos, y México en particular, han tenido una influencia positiva en la construcción de capacidades de conocimiento en las

7 Se hace referencia a estudios realizados en el marco del programa BID-CEPALPNUD (Katz, 1986 y 1987, entre otros), y por el proyecto financiado por el Banco Mundial sobre estos procesos en empresas de países en desarrollo (particularmente en India, Corea, Brasil y México). "Ambos proyectos, como lo afirma Vera-Cruz, han documentado procesos de aprendizaje tecnológico, mediante actividades tales como la negociación de tecnología, la asimilación de tecnología, la adaptación de maquinaria o la búsqueda de alternativas tecnológicas", (Vera-Cruz, 2003). 
propias empresas (Vera-Cruz, 2003), así como en otro tipo de organizaciones. Por lo que otro argumento a plantear en torno a la idea de sociedades basadas en el conocimiento es que los contextos externos e internacionales no siempre ni necesariamente limitan la posibilidad de generar conocimiento endógeno, sino que también pueden servir como detonantes de la construcción de capacidades internas, si se genera una capacidad creativa, se usa el conocimiento existente y se desarrolla un pensamiento estratégico para que el conocimiento sea motor de desarrollo.

ELEMENTOS PARA UNA CONCEPCIÓN DE POLÍTICA PARA EL CONOCIMIENTO Y LA INNOVACIÓN, CON UN ENFOQUE DE DESARROLLO SOCIAL SOSTENIBLE

Ante los enormes retos de avanzar en la construcción de sociedades basadas en el conocimiento, en un contexto de grandes inequidades sociales y de situación de pobreza de un gran espectro de la población, es fundamental repensar la concepción de política que impulsa el conocimiento y la innovación en nuestros países para lograr el desarrollo sostenible. Entre otros cabe hacer referencia a los siguientes elementos que es urgente modificar:

Definición de las estrategias y políticas para el conocimiento y la innovación, en el marco más amplio de las estrategias de desarrollo para nuestro país

La erradicación de la pobreza y la inequidad social debe ser la mayor prioridad de las políticas del conocimiento y la innovación. No es aceptable que nuestra población se vea aún privada de alimentos y agua potable, vivienda y atención sanitaria básica, cuando a nivel mundial y en nuestro país existe el conocimiento necesario para atender estos problemas.

En este marco los problemas de pobreza y cohesión social, crecimiento y empleo, alimentación, salud, ambiente y sustentabilidad 
deberán ser los ejes centrales que orienten el desarrollo del conocimiento y la innovación. Por lo tanto el conocimiento y la innovación son elementos sustantivos que deben considerar todas las políticas de desarrollo y no equivocadamente, como se ha hecho hasta ahora, como un sector independiente de políticas públicas. En cuanto a políticas de ciencia y tecnología, la concurrencia o convergencia de distintas disciplinas científicas, el abordaje transdisciplinario de los problemas, la interacción entre las ciencias naturales, exactas, sociales y las ingenierías, y el diálogo entre el conocimiento tradicional y el de frontera, deberán ser el esquema a seguir. Garantizar que se use el conocimiento existente y también el generado, así como estimular la generación de nuevo conocimiento para abordar problemas sociales urgentes, permitirá construir una nueva concepción de políticas públicas para el conocimiento y la innovación, y así incorporar de manera horizontal este recurso en todas las políticas sociales. Los procesos formativos y de educación de la población deberán incorporar la enseñanza sobre el valor social del conocimiento y la innovación, y el papel central que éstos tienen en un proyecto de desarrollo equitativo y sostenible.

\section{La diversidad cultural}

Las políticas para el conocimiento y la innovación deberán considerar que nuestro país es multicultural y que el aporte del conocimiento habrá de contemplar el mejoramiento de las condiciones de vida de los distintos grupos sociales en el marco de sus prácticas productivas, sus formas de organización y participación social, y sus patrones culturales y sus tradiciones. Las políticas de desarrollo social basadas en conocimiento no romperán las bases culturales de la población, sino que las revalorarán y mejorarán a partir de la apropiación de un conocimiento que garantice la sostenibilidad. Un ejemplo de esto sería la introducción de la computadora e Internet en comunidades indígenas, pero respetando los usos sociales que ellos determinen a partir de la asimilación de estas tecnologías. Hay evidencia en México acerca del uso social que distintos pueblos in- 
dígenas le están dando a Internet como una herramienta para preservar su cultura y sus lenguas, así como para comercializar sus productos y comunicarse con otros grupos sociales y culturales. Estas evidencias cuestionan ciertas posiciones respecto a la ampliación de la brecha digital entre pobres y ricos, como se ha venido difundiendo ampliamente (ver Gómez Mont, 2005). Sin embargo, el uso social que se haga de estas tecnologías dependerá de la forma en que éstas sean introducidas en los distintos grupos sociales.

\section{La sostenibilidad social}

La incorporación de conocimiento, tecnologías e innovaciones deberá contar con una previa evaluación de los impactos que éstas tendrían sobre las prácticas productivas, el medio ambiente y las condiciones de vida que se proponen modificar. En este sentido se hace necesario que en la definición de políticas de conocimiento e innovación, se genere una práctica de análisis de impactos ex ante. Esta actividad es un campo de trabajo muy amplio para los especialistas en Ciencias Sociales, quienes tendrían un papel central que jugar en la observancia del diseño y la aplicación de políticas que garanticen que el conocimiento y la innovación trabajen para el desarrollo humano y no en contra de éste.

Por lo tanto la construcción de sociedades basadas en el conocimiento requerirá de analistas de la dinámica social que sean capaces de reflexionar sobre las características específicas de los grupos sociales y que intervengan como agentes de reflexividad (Vaccarezza, 2007), y como agentes que apoyen el diseño de políticas del conocimiento socialmente relevantes.

En este eje de políticas deberá considerarse que los grupos sociales locales (no especialistas) adquieran las capacidades para intervenir en decisiones relacionadas con el uso del conocimiento. Grupos que sean capaces de discutir con los tomadores de decisiones sobre la pertinencia social de las decisiones basadas en el conocimiento. 
El crecimiento económico y la competitividad, con objetivos sociales y que contengan un enfoque global/local

El impulso al desarrollo productivo basado en el conocimiento deberá contemplar la dimensión regional y local en sectores estratégicos sociales, como la energía, el agua y el petróleo, así como en los sectores de tecnologías que mejoren la calidad de vida y la sostenibilidad. Asimismo el impulso al desarrollo productivo deberá orientarse a mejorar en particular la competitividad de las pequeñas y medianas empresas (PYMES) y las empresas sociales y contribuir así al desarrollo regional. Para ello se requiere conocer el desarrollo de estos sectores a nivel nacional e internacional, e integrar el conocimiento y la innovación que resulten socialmente relevantes. Sin embargo el crecimiento económico y la competitividad deberán tomar en cuenta las necesidades de desarrollo regional dentro del país, así como las especificidades y características locales en la generación de conocimiento, estimulando la iniciativa empresarial local. Hay que considerar que una de las características de la globalización que ha sido ampliamente documentada en diversos países es que lo global también le da oportunidades al desarrollo local, por lo que nuestro país deberá poner atención en estos espacios para orientar el desarrollo equitativo y sostenible de acuerdo con las capacidades y características de sus conformaciones regionales.

Las redes de investigación y de conocimiento

La construcción de procesos interactivos, la conformación de alianzas entre actores y el aprendizaje cotidiano en la formación de redes, son característicos de la ciencia, la tecnología y la innovación actuales. La idea de redes de conocimiento ha sido muy sugerente para analizar y conceptualizar los procesos de generación, distribución y apropiación o uso social del conocimiento. Lo que se denomina comúnmente redes de conocimiento constituye un caso particular de los enfoques de redes, que en combinaciones varia- 
bles han retomado elementos de los distintos enfoques, según se atienda a la morfología de la red, a su dinámica, al tipo de recursos o tipos de conocimiento que se ponen en juego, y según se ponga el acento en la red como un contexto de aprendizaje, o como un mecanismo de integración.

La idea básica es que los individuos son actores intencionales que tienen motivaciones sociales y económicas, cuyas acciones están influenciadas por una red de relaciones en las cuales están insertos, (Granovetter, 1973). Estos procesos son fundamentales para pensar en la construcción de sociedades basadas en el conocimiento, ya que mediante la interacción entre actores que realizan investigación y aquellos otros que producen conocimiento en otros contextos se logrará construir: procesos interactivos entre actores individuales, colectivos e institucionales (aprendizaje, deliberación); redes de conocimiento; cultura y lenguaje compartidos; confianza; normas y valores, e intercambio y apropiación de conocimiento. Estos procesos son fundamentales para la construcción de capital social basado en el conocimiento, que es un recurso sustantivo en la construcción de sociedades basadas en el propio conocimiento (Casas, 2001; Casas, 2005; Casas y Luna, 2011).

\section{La cohesión social y la gobernanza}

La estrategia de generación y uso del conocimiento, la ciencia, la tecnología y la innovación debe estar orientada a solucionar problemas de coordinación entre los agentes o actores que intervienen en estos procesos, y a dinamizar la generación de conocimiento. El incremento de financiamientos que no tienen estrategias de coordinación social no garantiza la sostenibilidad. En la medida en que se integren agentes, instituciones y procesos, las políticas y los instrumentos deberán formularse y diseñarse tomando en cuenta la evolución de las relaciones entre los agentes, el desempeño de las instituciones y la transformación de los procesos. Deberá concebirse dinámicamente el proceso y considerarse la situación actual de escasa interacción entre los agentes. 
Ello plantea desplegar los sistemas de generación y uso del conocimiento e innovación a nivel nacional, estatal y municipal, sobre las dinámicas que surjan del aprendizaje individual y colectivo de los agentes, los cuales conducirán hacia el logro de los objetivos. En las políticas públicas de conocimiento e innovación de largo plazo, cobran relevancia los mecanismos de coordinación y gobernanza que hacen posible la participación conjunta de las distintas organizaciones, instituciones y agentes involucrados. Esta estrategia se debe poner en práctica mediante la participación de los agentes de los sectores educativo y académico, del productivo y el empresarial, y también del gubernamental a los niveles federal, estatal y municipal del sector social y la sociedad civil. Este modelo de política de conocimiento e innovación debe definir formas de gobernanza que aseguren un equilibrio entre los niveles nacional, regional y local, y una firme coordinación intersectorial en cada uno de ellos.

\section{El nuevo papel del gobierno}

En este aspecto hay que considerar los cambios en el papel del gobierno no sólo en México sino también en el conjunto de América Latina y del mundo desarrollado. El papel evolutivo del gobierno, que ha ido de su gran poder político en la definición de políticas de ciencia, tecnología e innovación hasta un papel de articulador de los actores implicados en estas actividades, debe ser discutido. La importancia que están adquiriendo las procesos de aprendizaje y la definición de políticas de abajo hacia arriba mediante la interacción entre distintos agentes en el nivel local y regional debe ser considerada. Por tanto la discusión de un modelo de coordinación en la definición de políticas y el papel del gobierno en este proceso merecen una gran atención.

En esta discusión del nuevo papel del gobierno y del Estado hay algunos aspectos importantes del PLACTS en la década de los setenta en América Latina, que resurgen ahora bajo nuevas perspectivas. La idea de que las interacciones o los vínculos entre el gobierno, la academia y las empresas son fundamentales para de- 
tonar procesos de desarrollo ya habían sido planteadas en los años setenta y acuñadas en el concepto del "Triángulo de Sábato", (Sábato y Botana, 1968). En el marco de sociedades basadas en el conocimiento estas ideas han adquirido un carácter novedoso a nivel internacional. A fines de la década de los años sesenta, Sábato y Botana utilizaron la metáfora del triángulo con base en la cual se esperaba que el gobierno formulara políticas para integrar la infraestructura en ciencia y tecnología con el sector productivo. De acuerdo con estos autores "las políticas gubernamentales tienen una mejor oportunidad de ser implementadas en casos particulares en donde puedan controlar, si no totalmente, cuando menos parcialmente, los otros vértices del triángulo, como en los casos de las empresas del sector público y la infraestructura pública en ciencia y tecnología”. Este planteamiento fue hecho en una etapa en la que los tres actores estaban localizados en la esfera pública. También fue esto concebido por Sábato y Botana para los casos en que el Estado pudiera articular la infraestructura científica y tecnológica pública con el sector privado de las empresas.

Sin embargo el papel del Estado ha cambiado y los tres vértices del triángulo ya no están ubicados en la esfera pública; y asimismo han surgido nuevos actores y la sociedad civil ha adquirido un papel nodal. Esta es la razón por la que las políticas anteriormente denominadas gubernamentales deben evolucionar hacia políticas públicas que apoyen los intereses compartidos por un conjunto de actores.

En otros trabajos hemos planteado que a mediados de los años noventa se perfila un nuevo patrón de integración organizacional que involucra una intervención gubernamental de nuevo tipo, en la cual se busca una estabilización o normalización de las relaciones entre el gobierno, la academia, y el sector privado y el social, "a través de un nuevo esquema de relaciones institucionales y de valores compatibles, en donde la tensión entre la competencia y la cooperación tiene un papel central", (Luna, 1997; Casas y Luna, 1997). Este nuevo modelo de política de coordinación social destaca la participación de diversos actores en la formulación de políticas, así como el surgimiento de nuevos actores y la necesidad de generar consensos para atender los intereses comunes. 
En este nuevo escenario se han empezado a tejer fuertes vasos comunicantes con otros actores: comunidad científica, empresarios, sociedad civil, poder legislativo y los gobiernos estatales y locales. Estas nuevas formas organizacionales que se aprecian en el plano del diseño de políticas orientadas al desarrollo del conocimiento y la innovación, y que no han sido planteadas explícitamente desde arriba, están dando lugar a nuevas formas de configuración de relaciones para el desarrollo e intercambio del conocimiento. No obstante lo anterior, los temas de la sostenibilidad y la equidad no están en el centro de estas experiencias de coordinación entre los actores. Un ejemplo de ello podría ser un sector que hemos analizado en nuestras investigaciones en el noroeste del país: el acuícola, en el cual, a pesar de existir un conjunto amplio de actores participando en la generación, uso e intercambio de conocimiento, aspectos tales como la conservación de los recursos, la sustentabilidad ambiental, la relevancia social de los cultivos y el conocimiento tradicional no son considerados en las estrategias ni en las políticas públicas planteadas.

\section{A manera De CONCLUSIONES}

Necesitamos actualizar la idea de que el conocimiento, la ciencia, la tecnología y la innovación son factores clave para el desarrollo de América Latina. Concepción pionera en AL durante los años sesenta y setenta (PLACTS). Es preciso internalizarla ahora socialmente.

Hay mucho trabajo por hacer en cuanto al diseño de políticas a fin de que los actores sociales implicados en algún campo o problema urgente interactúen, pongan en el centro la importancia del conocimiento y formen consensos sobre cómo proceder.

La idea de las sociedades basadas en el conocimiento debe asignarles una gran importancia a los contextos externos e internacionales, en tanto éstos no limitan la posibilidad de generar conocimiento endógeno, sino que son necesarios como detonantes en la construcción de capacidades internas si se genera una capacidad 


\section{Sociedades basadas en el conocimiento y en los procesos de...}

creativa, se usa el conocimiento existente y se desarrolla un pensamiento estratégico para que el conocimiento sea motor de desarrollo.

Para concluir y volviendo a las preguntas formuladas al inicio de la exposición, quisiera sintetizar algunas de las argumentaciones desarrolladas.

En primer lugar quisiera regresar a cómo pensar en la construcción de sociedades basadas en el conocimiento; lo que se ha argumentado es que se trata de un tipo ideal de sociedad en donde el conocimiento debe estar en el centro de las relaciones sociales. $\mathrm{Y}$ aunque muchos autores afirman que todas las sociedades han estado basadas en el conocimiento, lo nuevo es que aspectos tales como la equidad en la distribución y uso, o la apropiación social, el aprendizaje social y la participación pública, son actualmente esenciales para pensar en el desarrollo sostenible que está en la base del concepto de las sociedades basadas en el conocimiento.

En cuanto a cuál debiera ser la concepción para orientar la generación y distribución del conocimiento en un país como México, que forma parte de los países del Sur, frente a las orientaciones que guían estas actividades en los países del Norte, destaca que tenemos que encontrar orientaciones propias, ya que los países del Norte no presentan las mismas condiciones estructurales de pobreza y marginación. Sus poblaciones han sido educadas y formadas durante ya hace un buen tiempo asignándole una importancia sustantiva al conocimiento y por ello se trata de poblaciones altamente educadas.

Por lo que se refiere a los criterios para definir políticas de conocimiento, ciencia, tecnología e innovación, con una visión de largo plazo que busque el desarrollo equitativo y sostenible, hemos señalado un conjunto de aspectos que es necesario introducir en una concepción distinta de estas políticas. Las políticas para el conocimiento y la innovación o las políticas de ciencia, tecnología e innovación en el largo plazo, deberán rescatar y estimular las dinámicas organizacionales y las interacciones entre los actores y los procesos de aprendizaje social, para configurar una estrategia que considere al conocimiento y la innovación como el motor fundamental del desarrollo social y económico sostenible en un mundo globalizado. 
El reto de una sociedad del conocimiento sostenible es muy grande, ya que alcanzar este tipo ideal de sociedad implica sostener un proceso de largo plazo de educación entre los distintos actores sociales, y una valoración social del conocimiento y la innovación y al papel central que éstos tienen en un proyecto de desarrollo equitativo y sostenible.

Nuestro reto en el largo plazo es ir rediseñando el modelo socioeconómico y el concepto de crecimiento actuales sustentándolos en las capacidades de conocimiento de diversos tipos y en el capital social existente, a partir de procesos interactivos y formación de redes sociales, y en el uso del conocimiento existente para mejorar las condiciones de vida de nuestra población.

\section{REFERENCIAS}

Casas, Rosalba (coord.) (2001), La formación de redes de conocimiento. Una perspectiva regional desde México, IIS-UnAm, Anthropos, Barcelona.

Casas, R. (2005), "Knowledge based social capital for local development", ponencia presentada en $5^{\text {th }}$ Triple Helix Conference: The capitalization of knowledge: cognitive, economic, social \& cultural aspects, Fondazzione Roselli, Turín, Italia, 18-21 mayo, 2005.

Casas, R. y M. Luna (coord.) (1997), Gobierno, Academia y Empresas en México. Hacia una nueva configuración de relaciones, IIS-unam/Plaza y Valdés, México.

Casas, R. y M. Luna (2011), "De redes y espacios de conocimiento, significados conceptuales y de política”, en A. Arellano y P. Kreimer (directores), Estudio Social de la Ciencia y la Tecnología desde América Latina, Colección Estudios Sociales de Tecnonciencia desde América Latina, Siglo del Hombre Editores, Bogotá, Colombia, pp. 167-208.

Chaparro, Fernando (2001), "Conocimiento, aprendizaje y capital social como motor del desarrollo", en Revista Ciencia de Información, Brasilia, vol. 30, núm. 1, enero-abril, pp. 19-31. 
Club de Roma (2002), Ningún límite al conocimiento, sino a la pobreza: Hacia una sociedad del conocimiento sostenible. En ocasión del $30^{\circ}$ aniversario del Primer informe del Club de Roma: Los límites del crecimiento, Contribución del Club de Roma a la Cumbre Mundial sobre el Desarrollo Sustentable, Johannesburgo, Sudáfrica.

Club de Roma (2003), "Hacia una nueva era de la información y el conocimiento para todos", en Exposición del Club de Roma a la Cumbre Mundial sobre la Sociedad de la Información, Ginebra, Suiza.

Dagnino, R. Thomas, Hernán y Davyt, Amílcar (1996), "El pensamiento en Ciencia, Tecnología y Sociedad en Latinoamérica: una interpretación política de su trayectoria”, en Redes, núm. 7, Universidad de Quilmes, Argentina.

Etzkowitz, H. (1994), "Academic-industry relations: a sociological paradigm for economic development", en Leydesdorff, Loet y Peter Van den Besselaar, Evolutionary Economics and Chaos Theory. New Directions in Technology Studies, Pinter, Londres, pp. 139-151.

Gómez Mont, C. (2005), Tejiendo hilos de comunicación. Los usos sociales de Internet en los pueblos indigenas, Tesis Doctoral en Ciencias Políticas y Sociales con especialidad en Comunicación, Posgrado en Ciencias Políticas y Sociales, unam, México.

Granovetter, M. S. (1973), “The strenght of weak ties”, en American Journal of Sociology, 78, (6), pp. 1360-1380.

Herrera, A. (1982-83), "Capacidade de Innovaçâo Tecnológica x Capacidade Social de Innovaçâo”, en Dagnino, R. (org.) (2000) Amílcar Herrera: um intelectual latinoamericano, Coletânea de artigos, UNICAMP, Campinas, São Paulo, Brasil.

Katz, J. (1986), Desarrollo y crisis de la capacidad tecnológica latinoamericana, BID-CEPAL-CIID-PNUD, Buenos Aires.

(1987), Technology generation in Latin American manufacturing industries, MacMillan, Londres.

López Cerezo, J.A. (2007), "Gobernabilidad en la Sociedad del Conocimiento", en EIDOS. Revista de Filosofía de la Universidad del Norte, mayo, Barranquilla, Colombia, pp. 122-149. 
Luna, M. (1997), "Modelos de coordinación entre el gobierno, el sector privado y los académicos", en Casas, Rosalba y Matilde Luna (coord.), Gobierno, Academia y Empresas en México. Hacia una nueva configuración de relaciones, IIS-unAm/Plaza y Valdés, México.

Sábato, J. y N. Botana (1968), "La ciencia y la tecnología en el desarrollo futuro de América Latina", en Revista de la Integración, INTAL, Buenos Aires, año 1, núm. 3, pp. 15-36.

Tilak, J. B. G. (2002), "Knowledge society, education and aid", Compare, vol. 32, (3), pp. 297-310.

Toffler, A. (1990), Power Shift, London, Bantam Press.

Unesco (2003), "From Information Societies to Knowledge Societies", Background paper, UNESCO and the World Summit on the Information Society, Ginebra, Suiza.

Vaccarezza, L. (2007), "Cultura científica en la sociedad del conocimiento", ponencia presentada en el Seminario Internacional Las Ciencias Sociales: Reflexiones sobre su Futuro y Retos, 21-22 agosto, IIS-unam, México.

Vera-Cruz, A. (2003), "Apertura económica, exportaciones y procesos de aprendizaje. El caso de la Cervecería Cuauhtémoc-Moctezuma”, en: Aboites, J. y G. Dutrenit (coord.), Innovación, aprendizaje y creación de capacidades tecnológicas, UAM-Xochimilco, Miguel Ángel Porrúa, México, pp. 269-309. 


\title{
El Diplomado en Administración y Preservación de Archivos Digitales del cuiB
}

\author{
JuAn Voutssas \\ Instituto de Investigaciones Bibliotecológicas \\ $y$ de la Información, UNAM
}

INTRODUCCIÓN

Tada día son más las empresas y organizaciones que crean y
guardan sus documentos de archivo en formatos digitales:
bancos, compañías de seguros, financieras, centros bursáti-
les, universidades y escuelas, hospitales, almacenes, librerías, etc.,
en los cuales se encuentra una variedad enorme de información
almacenada de sus actividades y que tienen como resultado más
acervos documentales digitales de cuentas bancarias y de inversio-
nes, préstamos y pagos, pólizas, expedientes estudiantiles y médi-
cos, compras y ventas -tanto presenciales como en-línea-, perfiles
de usuarios, catálogos y manuales de productos y servicios, ade-
más de su propia información interna. Hoy en día la factura elec-
trónica, el pago o transferencia electrónica, la compra de bienes
y servicios en-línea, la firma electrónica, etc., son ya cotidianos y
tienden a incrementarse cada vez más, y a dejar huellas y docu-
mentos digitales.
Del mismo modo, los servicios gubernamentales registran cada
vez más trámites oficiales que guardan información digital acerca
de sus usuarios y sus transacciones: actas de registro civil; senten-
cias y resoluciones de juzgados y cortes; pagos de impuestos y
otros datos hacendarios; actas de calificaciones y exámenes; certifi-
cados de estudios; oficios, correos, memorandos; reportes, contra- 
tos, patentes, convenios; trámites vehiculares, pasaportes y visas, tratados internacionales, etc. Esto puede verse a nivel de los tres poderes y de los diversos servicios que prestan el gobierno federal y los estatales o locales. Y estas operaciones tienden a incrementarse cada vez más, dejando también huellas y documentos digitales.

Un gran problema con el crecimiento exponencial de la información perteneciente a archivos es ahora ¿cómo administrarlo correctamente? ¿Cómo llevar a cabo los procesos y controles que permitan llevar a cabo las bajas o eliminaciones de documentos que ya no son útiles así como las transferencias hacia un archivo histórico de aquellos documentos digitales que requieren preservarse a largo plazo? No es un simple problema de almacenamiento de información digital en dispositivos electrónicos para ese efecto. Los archivos digitales presuponen e imponen un conocimiento y habilidades inéditas por parte de los responsables de ellos. La norma ISO 15489:2001 Information and Documentation: Records Management: Part 1. General establece que "[...] los documentos de archivo deben ser auténticos, confiables, completos, sin alteración, y deben permitir su uso y acceso. Asimismo, deben poseer metadatos que definan el contexto, contenido y estructura y deben reflejar con precisión la comunicación, acción o decisión para la que fueron creados".

El reto principal surge de la necesidad de administrar estos acervos de archivos documentales digitales siempre crecientes, y de garantizar al mismo tiempo su autenticidad y preservación por décadas y hasta siglos.

Una de las principales metas del Proyecto InterPARES 3 -The International Research on Permanent Authentic Records in Electronic Systems- es desarrollar estrategias para introducir las temáticas relacionadas con los documentos de archivo digitales y preservarlos dentro de los programas de formación en las empresas, talleres de educación continua así como en los planes de estudios dentro de programas educativos curriculares de licenciatura y posgrado. Este diplomado se deriva directamente de esta meta de InterPARES 3 y pretende presentar una acción concreta para formar a los profesionales que trabajan actualmente con archivos o documentos de 
archivo y tienen la tarea de mantener de forma segura cuerpos documentales auténticos para que se conserven a largo plazo. El alcance de este documento es hacer un resumen de los esfuerzos más importantes realizados por el TEAM México ${ }^{1}$ en este esfuerzo.

\section{EsTADO DE LA CUESTIÓN}

Durante la reunión cumbre de InterPARES en 2009 en Seúl, el TEAM México presentó un plan para desarrollar su estrategia en la educación y la formación de recursos humanos. El punto que daba origen a los temas presentados en este documento se refería

[...] a la formación interna y los programas de talleres de educación continua para los que ya se encargan de los registros digitales y otros materiales digitales para los cuales percibimos que no existe un programa ya estructurado para hacer tal cosa. Se encontraron sólo esfuerzos aislados debido a que el aislamiento y la falta de planificación articulada tienen un muy bajo impacto en nuestro entorno de archivo. Por lo tanto, como ocurre también en otras regiones y países, los registros digitales por lo general estaban en manos de profesionales de tecnología de la información que tenían un conocimiento escaso o nulo sobre las prácticas formales de archivo y la cultura de organización útil para la creación adecuada, la gestión y la conservación de materiales digitales. ${ }^{2}$

He aquí una tabla resumen de las asignaturas más relacionadas con la temática de gestión y preservación de documentos de archivo en las escuelas que imparten esta carrera (Tabla 1):

1 TEAM: además de equipo, son las siglas del enfoque Theoretical Elaborations into Archival Management. Por eso no se traduce.

2 J. Voutssas et al. (2009), "A strategy for Training on Digital Records Preservation in Mexico", InterPARES 32009 Summit Symposium. Seoul. Korea. National Archives of Korea. Sept. 2009. 424 p., pp. 413-424. 
Oportunidades y retos en la formación, investigación y aplicación...

\begin{tabular}{|c|c|c|c|c|c|c|c|c|c|c|c|c|c|c|c|c|}
\hline \multirow{5}{*}{$\frac{-1}{\frac{\pi}{2}} \frac{\pi}{\frac{\pi}{2}}$} & 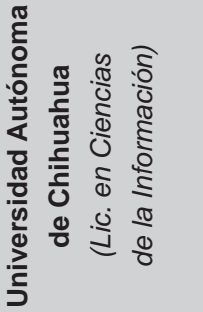 & 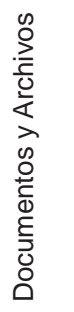 & 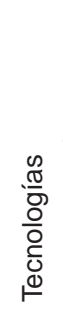 & 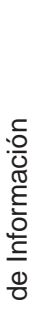 & 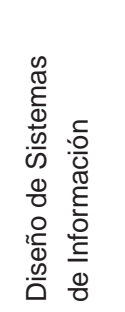 & 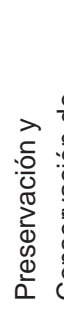 & 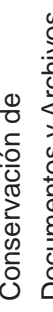 & 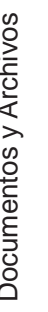 & 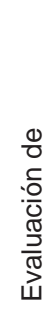 & 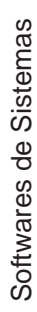 & 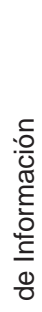 & & & & & \\
\hline & 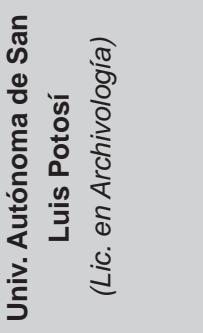 & 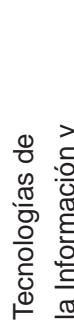 & 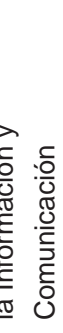 & & 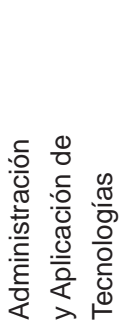 & & 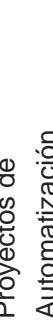 & 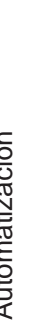 & 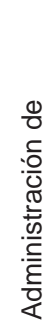 & 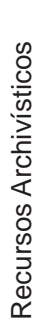 & & 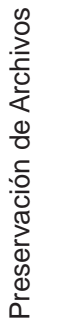 & & & & \\
\hline & 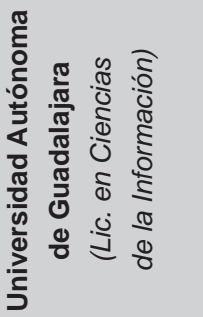 & 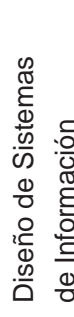 & $\frac{\bar{c}}{\frac{c}{0}}$ & 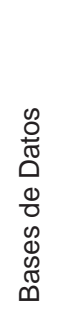 & 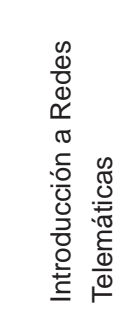 & & 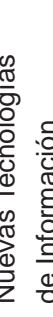 & $\frac{\bar{c}}{\frac{\delta}{0}}$ & & & & & & & & \\
\hline & 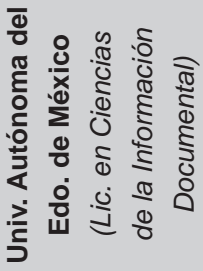 & 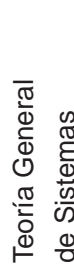 & 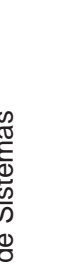 & 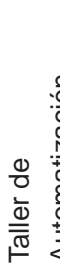 & 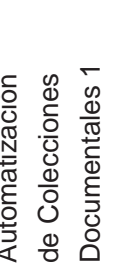 & $\begin{array}{l}\frac{\otimes}{0} \\
\frac{0}{\bar{\sigma}}\end{array}$ & 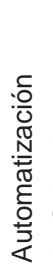 & 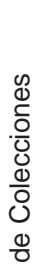 & 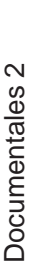 & & & 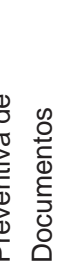 & & & & \\
\hline & 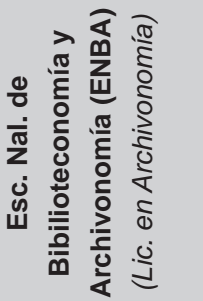 & 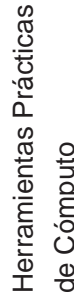 & $\begin{array}{l}0 \\
0 \\
\frac{8}{2} \\
0 \\
0 \\
0 \\
0\end{array}$ & 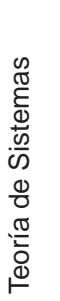 & 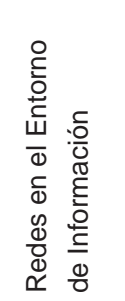 & 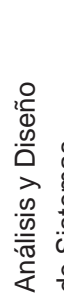 & $\begin{array}{l}\frac{n}{0} \\
\frac{0}{0} \\
\frac{0}{0} \\
0 \\
0 \\
0 \\
0\end{array}$ & 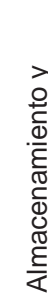 & $\begin{array}{l}\frac{1}{0} \\
\frac{1}{0} \\
\frac{0}{0} \\
\frac{\pi}{0} \\
\frac{0}{7} \\
0 \\
0 \\
\square\end{array}$ & $\begin{array}{l}\frac{}{0} \\
\frac{0}{0} \\
\frac{\text { ह }}{0} \\
\text { 으 }\end{array}$ & & 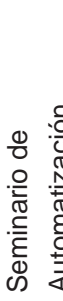 & 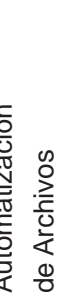 & & 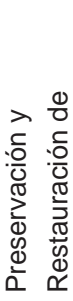 & ? \\
\hline
\end{tabular}


Existen otras carreras y posgrados afines, como las licenciaturas en bibliotecología de varias instituciones (unam, Univ. Aut. de Nuevo León, U. de Guadalajara, Univ. Aut. de Chiapas), la Maestría en Ciencias de la Información y Administración del Conocimiento del ITESM, la Maestría en Bibliotecología de El Colegio de México, pero éstas o tienen como objeto principal la bibliotecología y en sus asignaturas relacionadas a otras ciencias de la información, o no tocan en lo absoluto la preservación documental. Por esta razón no fueron integradas a la tabla. Existen también carreras como la Lic. en Tecnologías de la Información de la U. de Guadalajara, etc., pero tampoco tocan para nada la temática de preservación archivística.

Como puede observarse, los mapas curriculares de las escuelas mencionadas previamente tienen que ver casi en su totalidad con documentos de archivo en soportes tradicionales; las asignaturas tales como: "automatización de documentos de archivo y fondos documentales" se refieren al desarrollo de sistemas de creación de documentos de archivo, o a bases de datos documentales, o a procesos de digitalización documental retrospectiva. Obviamente que es importante para los administradores modernos de archivos aprender acerca de las TIC pero la enseñanza de éstas se limita a otras temáticas y no a la de preservación de archivos digitales. Las asignaturas que se imparten acerca de preservación documental están enfocadas sin excepción a soportes tradicionales.

Por otro lado encontramos ya muchas instituciones educativas, productivas, financieras, de salud, etc., tanto públicas como privadas, y en especial instituciones gubernamentales de los tres órdenes, que tienen ya entre sus actividades la creación y manutención de documentos de archivo digitales pero que carecen de las políticas, procedimientos $\mathrm{y}$ normativas útiles $\mathrm{y}$ pertinentes para hacer una preservación confiable. Existe un esfuerzo para establecer ciertas políticas generales a través de la Ley Federal de Archivos de México, cuya aprobación por el Senado mexicano aún está pendiente, a pesar de que ya ha sido aprobada por la Cámara de Diputados; en ella se establece al Archivo General de la Nación como institución guía para precisar las directrices para el uso, la creación y la preservación de los sistemas de documentos de archivo tradicionales 
y digitales, y también introduce la obligación de las agencias y oficinas gubernamentales para desarrollar políticas y directrices relacionadas con el control de los documentos de archivo digitales a fin de aplicar instrumentos homogéneos de archivo (esquemas de clasificación, tablas de disposición, etcétera), semejantes a los que se utilizan para los documentos de archivo tradicionales, así como para la creación, mantenimiento y preservación de los metadatos y la documentación de cualquier estrategia de mantenimiento tales como la migración, actualización de software o hardware, etcétera. ${ }^{3}$

También vale la pena mencionar que la Ley Federal Mexicana para la Transparencia y Acceso a la Información Gubernamental -que incluye datos personales y la protección de información confidencial- exige que los documentos de archivo y los archivos deben estar debidamente organizados. ${ }^{4}$ Esta ley también comprende documentos de archivo electrónicos.

Teniendo en cuenta las cuestiones antes mencionadas, InterPARES México decidió diseñar una estrategia con el fin de remediar la falta de conocimiento formal y estructurado que prevalece en el medio mexicano en los documentos de archivo digitales y su preservación. Los objetivos de esta estrategia fueron:

Capacitar al personal que actualmente es responsable o colabora en un archivo digital.

Entrenar profesionales en asesoría y auditoria de archivos digitales.

Capacitar alrededor de necesidades específicas.

Formar potenciales de cuadros docentes.

Para poder implementar esta estrategia se definieron varias etapas que habría que desarrollar. Como primer paso se investigó la situación docente de la materia, el segundo paso consistió en desa-

3 Ley Federal de Archivos. Gaceta Parlamentaria del Senado del 24 de marzo de 2009, pp. 31-36, disponible en: http://www.senado.gob.mx/gace.php?sesion=2 009/04/02/1\&documento $=6$.

4 Ley Federal de Transparencia y Acceso a la Información. Disponible en: http:// www.oas.org/juridico/spanish/mec_avance_mexV.pdf 
rrollar contenidos específicos para el diplomado; todo el material original debería estar en español.

Adquirir conocimiento acerca de la enseñanza y capacitación relativa a documentos de archivo digitales y a su preservación

Con el fin de desarrollar el plan de estudios apropiado para este objetivo se revisaron los cursos y talleres de educación continua así como las temáticas de planes curriculares utilizados con este propósito, los cuales fueron adaptándose de acuerdo con lo que se consideró lo mejor para nuestro medio y complementándose con el desarrollo de nuevos contenidos cuando así se consideró pertinente.

Con respecto a la parte de capacitación y entrenamiento se revisaron los programas y materiales de las siguientes organizaciones:

Para educación continua:

* El Proyecto InterPARES: http://www.interpares.org

* El Consejo Internacional de Archivos, (The International Council of Archives): http://www.ica.org/en/resource-centre

Los Electronic Records Archives of the National Archives and Records Administration: http://www.archives.gov/era/index.html

Los Archivos Nacionales del Reino Unido, (The National Archives of the United Kingdom): http://www.nationalarchives.gov. uk/preservation/digital.htm

El International Records Management Trust: http://www.irmt.org La Sociedad de Archivistas Americanos, (The Society of American Archivists): http://www.archivists.org/menu.asp?m=education La Asociación de Archivistas de Cataluña, (Associació d'Arxivers de Catalunya): http://www.arxivers.com/esp/quisom2.asp

Como currículos académicos se revisaron los de las siguientes universidades:

University of British Columbia, Canada: http://www.slais.ubc.ca/ COURSES/courses-summary.htm 
Oportunidades y retos en la formación, investigación y aplicación...

Universidad de Barcelona: http://www.ub.edu/graus/

University of Michigan: http://www.si.umich.edu/msi/arm.htm

Glasgow University: http://www.gla.ac.uk/postgraduate/taught/ arts/informationmanagementpreservationdigitalarchivesrecordsmanagement/

Universidad Carlos III de Madrid: http://www.uc3m.es/portal/ page/portal/postgrado_mast_doct/masters/mu_archivistica/program

Universidad de Salamanca: http://www.usal.es/webusal/node/474 http://www.usal.es/webusal/files/MasterInformacionDigital.pdf Universidad La Salle de Colombia: http://sisinfo.lasalle.edu.co/

\section{Desarrollo de contenidos}

Como ya se mencionó existe poco material específico para la enseñanza de estas temáticas, y prácticamente nada en español. Una vez que se estableció el material aprovechable ya creado en otras instancias, se procedió a diseñar y a construir el material apropiado y expresamente construido para ese efecto. Por lo mismo esta etapa nos dio la oportunidad de diseñar nuestros propios contenidos para la formación específica en forma de educación continua, así como los planes de estudio desde un punto de vista curricular; los contenidos se desarrollaron en primer lugar para alcanzar el conocimiento general de los documentos de archivo digitales y su preservación, seguido de temas específicos. Por ello se desarrollaron contenidos que presentan el estado del arte de los materiales de la fase 2 del proyecto InterPARES, las normas ISO 15489, estándares y mejores prácticas por parte del Consejo Internacional de Archivos, los modelos OAIS, MoReq 2 y otros. Es importante destacar que se tuvieron que desarrollar contenidos acerca de la naturaleza de los documentos de archivo y archivos digitales, y también los relacionados con la conservación digital y los relacionados con Tecnologías de Información y Comunicaciones (TIC). Con estos contenidos la idea básica es poder capacitar a futuros instructores y profesores que, por medio de la inducción de una estrategia de auto aprendizaje 
permanente, nos ayuden a desarrollar los futuros contenidos específicos sobre la conservación u otro tipo de cuestiones relacionadas con los archivos digitales, como la cultura organizacional, las teorías contemporáneas de archivo y diplomática, la práctica o la gestión de servicios públicos, los archivos locales y documentos de archivo y también acerca de la regulación o el acceso a la información, la privacidad y los derechos de autor; y en un futuro el desarrollo de cursos y talleres sobre necesidades y temas más específicos.

Era deseable una amplia variedad de temáticas con el propósito de abarcar aspectos muy diferentes relativos a la preservación de archivos digitales. Por tanto se determinó que lo ideal sería un curso de tipo diplomado, con una estructura completa y transdisciplinaria de profesores. Como es sabido, en el medio mexicano los diplomas son altamente valorados por los profesionales y los empleadores, y por lo mismo tienen amplia demanda. Por supuesto, los diplomas ofrecidos por instituciones reconocidas y acreditadas tienen el más alto valor entre todos ellos.

\section{El Diplomado en Administración y Preservación de Archivos Digitales del CUIB}

Los objetivos del diplomado son

Proveer a los estudiantes del conocimiento y las habilidades tecnológicas y archivísticas que los habiliten para comprender integralmente la creación, gestión, transferencia y preservación de fondos documentales y archivos digitales.

Capacitarlos para poder administrar profesionalmente documentos de archivo digitales que ya existen en sistemas y servidores de instituciones públicas y privadas, en especial aquellas del egobierno.

* Enseñarles a diseñar y desarrollar planes institucionales, estrategias, políticas, lineamientos, etc., con las mejores prácticas internacionales alrededor de la gestión y preservación a largo plazo de documentos de archivo digitales fiables. 
Está dirigido a

Administradores de documentos de archivo, archivistas, profesionales de las TIC, responsables de repositorios documentales públicos, funcionarios responsables de la administración, preservación y transparencia de archivos públicos, planeadores, tomadores de decisiones y auditores relacionados con documentos y archivos digitales.

\section{Sede}

Dado que el Centro Universitario de Investigaciones Bibliotecológicas (cuiB) ${ }^{5}$ de la Universidad Nacional Autónoma de México (unam) es el principal centro de investigación en el campo de ciencias de la información en México y probablemente en toda América Latina, es requerido con frecuencia por muchas instituciones gubernamentales y privadas para actuar como consultor en problemas específicos de información. A menudo, el сиiв actúa como un "tercerizador" -outsourcer- en problemas prácticos de "inteligencia de negocios" y proyectos relacionados con la información. Con frecuencia dentro de este tipo de trabajo, esas instituciones le solicitan al Centro programas específicos de entrenamiento, expresamente diseñados y administrados por los investigadores del cuiB y otros profesionales al efecto. Por lo mismo, el Centro tiene una fuerte tradición en el diseño, construcción e impartición de este tipo de programas, por cuya calidad e innovación es ya ampliamente reconocido. Además, el TEAM México de InterPARES estaba consolidado y actuaba ya como consultor en los problemas específicos de la preservación de archivos digitales, y por extensión podía actuar en el diseño de programas internos de capacitación dirigidos a los archivos digitales

5 Cabe aclarar que el Centro Universitario de Investigaciones Bibliotecológicas (сuiB), a partir del 30 de marzo del 2012, se constituyó como Instituto de Investigaciones Bibliotecológicas y de la Información (IIBI); empero, el diplomado sigue activo bajo la misma estructura. 
existentes en las unidades de registro que tienen la tarea de mantener de forma segura los cuerpos documentales que hay que preservar en el largo plazo. Dado que además el Centro es la sede del TEAM México del Proyecto InterPARES, era evidente que el cuiB ofrecía la sede más atractiva para el diplomado y por consecuencia éste fue insertado dentro de los programas de educación continua del Centro.

El diseño final del diplomado consiste en un curso de educación continua, con 152 horas de clase, duración de 19 semanas, 8 horas por semana y sesiones viernes y sábado; el cupo es de 20 alumnos. Está conformado por 6 "módulos" o unidades educativas impartidas por un grupo variado y transdisciplinario de instructores; el diplomado incluye material teórico y práctico de diversas temáticas destinadas a proveer al estudiante con un mayor conocimiento y habilidades acerca de la problemática y las soluciones actuales que hay para la administración profesional y la preservación a largo plazo de archivos digitales fiables. Al final de cada módulo se imparte una conferencia magistral relacionada con éste por parte de un experto en el tema.

Requisitos para la obtención del diploma

Al final del curso y para demostrar sus conocimientos teóricoprácticos, cada estudiante debe desarrollar y presentar un proyecto que pruebe sus conocimientos y habilidades adquiridos acerca de la creación, gestión, transferencia y preservación de cuerpos documentales y archivos digitales o el diseño de un plan para una organización real y que contenga una estrategia y mejores prácticas para la preservación a largo plazo de archivos digitales fiables. El alumno deberá tener un mínimo de $80 \%$ de asistencias y tareas, y tendrá que haber participado activamente en grupos de trabajo. 
Oportunidades y retos en la formación, investigación y aplicación...

Programa

Módulo 1. (Propedéutico). Introducción a la ciencia arcbivística moderna y a los archivos (16 hrs.)

Objetivo: Introducir al participante en la identificación y el análisis de los conceptos actuales e instrumentos técnicos básicos de la disciplina archivística a fin de que pueda construir una base conceptual en las actividades que desarrolla.

\section{Temario}

Conceptos y definiciones en el entorno de la archivística

- Qué es un archivo.

- El documento de archivo.

- La administración de archivos.

- Sistemas de gestión de archivos.

Teorías y modelos documentales archivísticos fundamentales

- El "ciclo de vida" de un documento de archivo.

- La "teoría de la continuidad" de los documentos de archivo.

* La clasificación de los documentos de archivo

- Conceptos, clasificación y cuadros de clasificación archivística.

- Elementos que deben considerarse en la construcción de los cuadros de clasificación archivística.

El proceso de valoración documental

- Teorías sobre la valoración documental.

El catálogo de disposición documental

- Construcción y uso de un catálogo de disposición (descarte) documental.

Conferencia: "El Archivo General de la Nación: Perspectivas actuales". 
Módulo 2. (Propedéutico). Las Tecnologías de Información y Comunicaciones (TIC) y su relación con la ciencia archivística (36 brs.)

Objetivo: Introducir al participante en los conceptos básicos, elementos, herramientas y metodologías utilizados hoy en día en las TIC (Tecnologías de Información y Comunicaciones) y que están relacionados con los archivos digitales.

Temario

Estructura física

- Unidades de entrada y salida.

- Unidad Central de Procesamiento.

- Unidades de almacenamiento de datos.

* Estructura lógica

- Sistemas numéricos, conceptos básicos: bit, byte, pixel, dpi, etcétera.

Programas

- Del sistema.

- Programas de carga o inicio.

- Sistemas operativos.

- Controladores de dispositivos.

- De aplicación.

- Procesadores de texto, hojas de cálculo, presentaciones etcétera.

- Manejadores de bases de datos.

- Programas de gráficos y diseño.

- Programas de comunicaciones.

* Lenguajes de programación.

- Compiladores e Intérpretes.

- Sistemas operativos.

- Windows, MacOS, OS/2, MS-DOS, Unix, Linux y sus variantes. Ventajas y desventajas.

Redes e Internet

- Topología de redes. 
Oportunidades y retos en la formación, investigación y aplicación...

- Tipos de redes.

- Protocolos.

Bases de datos

- Definición.

- Tipos de bases de datos.

- Estructura de las bases de datos: los datos dentro de las bases.

Software propietario y no propietario. Estándares. Interoperabilidad

Formatos para preservación y formatos para distribución documental

- Para texto, imagen fija, imagen en movimiento, sonido, etcétera.

- Compresión con y sin pérdida.

- Calidad y resolución.

El documento digital de origen y el documento digitalizado

Digitalización de documentos de archivo y sus conceptos

- Justificación y tipos de digitalización - OCR.

- Resolución, profundidad, paletas de color y con escala de grises.

- Bitmaps, rasterización, muestreo y fidelidad, compresión con y sin pérdida.

- Costos de digitalizar y sus costos asociados: capturar, editar, almacenar, registrar, preservar, etcétera.

- Cálculo del tamaño de archivos.

- Control de calidad.

Almacenamiento digital

- Unidades de medición, dispositivos, capacidades y costos.

- En-línea y fuera de línea.

Firma Electrónica Avanzada (FEA o FIEL)

- Conceptos. Infraestructura de llave pública (PKI). Certificado digital.

- Autoridad certificadora. Remoción de firmas para preservación final.

Procesos tecnológicos de conservación digital

- Réplica, refrescado, emulación, encapsulado, etcétera.

Seguridad informática y preservación archivística:

- Principios, recursos, riesgos, amenazas, vulnerabilidades, impactos. 
- Características y atributos del documento bajo seguridad.

- Estrategia y metodologías para la gestión de la seguridad informática.

- Análisis de riesgos y estado de la seguridad.

- Estándares metodológicos para la seguridad informática.

- ISO 17799, ISO IEC 27001, 27002, 27006, EA-7 03.

- Los diez dominios del estándar ISO 27001.

- Los 36 objetivos de control y las 127 acciones de control del ISO 27001.

Conferencia: "Producción de Materiales Digitales en el Mundo. Estado Actual, Tendencias y Prospectiva".

Módulo 3. Un plan para documentos de archivo. Planeación $y$ administración (IRMT) (20 brs.)

Objetivo: Que el participante comprenda todos los elementos y metodologías que impactan en el desarrollo de la planeación y la administración de archivos documentales, y cómo estos elementos incidirán positiva o negativamente en la preservación documental.

\section{Temario}

El Análisis de caso.

* La exploración y la encuesta.

* El desarrollo de políticas.

La planeación de un sistema de gestión documental archivística. Los procedimientos dentro de los sistemas de gestión de documentos de archivo

* Selección e instrumentación de un sistema de gestión archivística.

Indicadores y buenas prácticas.

* Plan de acción sobre la administración electrónica. 
Oportunidades y retos en la formación, investigación y aplicación...

Conferencia: "Los archivos digitales y la seguridad informática. El caso Wikileaks".

\section{Módulo 4. Estado del arte mundial de los documentos de archivo digitales ( 24 brs.)}

Objetivo: Inducir al participante a analizar e integrar el conocimiento actual respecto de los documentos de archivo digitales y sus tendencias a fin de que esté en posibilidades de identificar aspectos actuales y futuros que sean útiles en el entorno de su actividad profesional.

\section{Temario}

La naturaleza de los documentos de archivo digitales

- Documentos de archivo digitales, definiciones, características y funciones (InterPARES).

- Ontologías básicas (InterPARES).

- Documentos de archivo digitales y sus partes: componentes, atributos, personas, formas.

- Estado de transmisión y grado de perfección de un documento de archivo.

- Confianza, autenticidad, exactitud, fiabilidad, integridad, identidad, completitud, veracidad, pertinencia, corrección y precisión, procedimiento de creación.

- Definiciones y conceptos de los documentos de archivo digitales según la ISO 15489.

Documentos de archivo digitales y legislación

- Acceso a la información y transparencia.

- Derechos de propiedad intelectual.

- Protección de datos personales, etcétera.

- Legislación y archivos digitales.

Problemas, retos, riesgos y oportunidades que impactan en datos, información y documentos de archivo digitales

- Positivos 
- Intercomunicación ágil, eficaz y gratuita.

- Mayor información y distribución de datos e información.

- Colaboración.

- Negativos

- Piratería y falta de aplicación de derechos de autor.

- Pérdidas y fugas de la información (El caso Wikileaks).

- Información poco validada y confiable.

- Revisión y análisis de artículos sobre el tema.

Nuevos retos en la administración de los documentos de archivo digitales

- La problemática de los metadatos y la terminología.

- Definiciones previas.

- Vocabularios controlados.

- Definición de taxonomía y tesauro.

- Vocabularios no controlados.

- Folksonomías y ontologías.

- Definición y formalización de mapeos entre vocabularios.

La terminología archivística en el entorno de los documentos digitales de archivo

La nube

- Conceptos, categorías y herramientas para generar nubes de tags,

Las redes sociales

- Carpeta de favoritos,

- Marcadores sociales o colectivos: ventajas y desventajas.

- Etiquetado de recursos: Del.icio.us, Flickr.

- Indización o etiquetado social: ventajas y desventajas.

e-gobierno

- Concepto e importancia; contextualización en diversos ámbitos.

- Gobierno conectado y gestión de casos: etapas.

- e-gobierno centrado en las necesidades del ciudadano.

Conferencia: "e-gobierno en México”. 
Oportunidades y retos en la formación, investigación y aplicación...

\section{Módulo 5. Sistemas de creación y mantenimiento de docu- mentos de archivos digitales (gestión documental) (32 brs.)}

Objetivo: Enseñarle al participante los elementos que le permitan el desarrollo de políticas, lineamientos y la aplicación de metadatos útiles en la definición e instrumentación de un sistema de creación y mantenimiento de los documentos de archivo.

\section{Temario}

Normas estándares, requisitos y criterios para gestionar los documentos de archivo (creación y mantenimiento)

- ISO 15489

- MoReq 2

- DoD 5015.2

- ISO 26122

- Requisitos funcionales del Consejo Internacional de Archivo.

- Lineamientos para documentos digitales de archivo en ambientes de la nube, la Web.2.0 y e-gobierno.

Metadatos para documentos de archivo digitales

- La importancia de los metadatos en el manejo de los archivos digitales.

- La ISO 23081 de metadatos para archivos digitales.

Los productos del Proyecto InterPARES

- Los requisitos para evaluar la autenticidad de los documentos digitales de archivo.

- La guía para la creación de archivos.

- El Modelo de la Cadena de Preservación.

- El análisis contextual de los documentos de archivo.

- Creación y mantenimiento de los documentos de archivo.

- Políticas y lineamientos para la creación y el mantenimiento de los documentos de archivo.

- Requisitos básicos y metadatos para sistemas de creación de documentos de archivo digitales.

- Requisitos básicos y metadatos para sistemas de mantenimiento de documentos de archivo digitales. 
- Los documentos de archivo digitales y la nube, las redes sociales y el e-gobierno.

- Análisis de propuestas de solución.

Análisis a través de casos de estudio arquetípicos

Conferencia: "La situación de los sistemas de gestión documental en México".

Módulo 6. Sistemas de preservación de documentos de archivo digitales auténticos y a largo plazo (InterPARES) (24 hrs.)

Objetivo: Enseñarle al participante todos los elementos que conforman la creación de archivos documentales digitales y todos los elementos que inciden en su preservación en forma auténtica y a largo plazo.

\section{Temario}

El modelo de la Cadena de Preservación del Proyecto InterPARES - Preservación de los documentos de archivo.

Lineamientos básicos para la preservación de archivos digitales InterPARES

- Planeación de un sistema de preservación de archivos digitales.

- El sistema de preservación.

- Valoración documental en los documentos de archivo digital.

- Transferencia e ingreso de documentos de archivo.

- Estrategias de preservación.

- El acceso actual y futuro a los documentos de archivo.

Los requisitos para mantener los documentos digitales de archivo en el largo plazo

El modelo OAIS (Open Archival Information System)

La "Lista de Auditoría para Certificación de Repositorios Digitales" de NARA/RLG

Estudios de caso: iniciativas internacionales para la preservación de archivos digitales 
Oportunidades y retos en la formación, investigación y aplicación...

- Archivos Nacionales de Estados Unidos de Norteamérica.

- Archivos Nacionales del Reino Unido.

- Repositorios digitales para preservación en el largo plazo de información y archivos sobre ciencias sociales.

Mesa redonda sobre documentos de archivo digitales

Presentación del proyecto final por parte de los alumnos

Desarrollo de material curricular

La estrategia de capacitación planteada contempla como siguiente paso el desarrollo de un plan curricular para dos asignaturas optativas de la Maestría en Bibliotecología y Estudios de la Información, que imparte la unAm a través del cuiB y la Facultad de Filosofía y Letras; una de estas asignaturas tiene como temática la gestión de archivos digitales y la otra la preservación de los mismos.

Asimismo el TEAM México está desarrollando un conjunto de contenidos para diversas asignaturas alrededor de estas temáticas a nivel licenciatura. Se pretende insertar estas asignaturas en el plan de estudios de Bibliotecología de la UNAM y estudiar la posibilidad de que sean adoptadas en alguna otra de las escuelas de archivística mencionadas al principio de este documento.

Finalmente se contempla el desarrollo de conjuntos específicos de programas de capacitación diseñados expresamente para organizaciones públicas, privadas, educativas, etc., que así lo soliciten.

Como puede deducirse de este documento, aún queda mucho por hacer en el aspecto de la formación de recursos humanos capacitados en la gestión y preservación de documentos de archivo digitales, pero sin duda con esta estrategia y este diplomado se ha dado un importante paso en este sentido, sobre todo porque es un programa abierto y que busca formar nuevos profesionales capacitados que además de desarrollarse profesionalmente, puedan formar a su vez nuevos cuadros profesionales. 


\title{
Perspectivas del patrimonio artístico en México
}

\author{
Renato GonzÁlez Mello \\ Instituto de Investigaciones Estéticas, UNAM
}

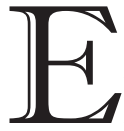

stando en Nueva York en 1928, en una estancia que se prolongó hasta 1934, José Clemente Orozco quiso mostrar sus murales de México ante el público estadounidense. Su meta era conseguir encargos de pintura mural en aquel país. No es fácil exhibir un mural. Los murales se pintaron para no poderse exhibir. Su propósito más importante fue no ser pintura de caballete, no poderse vender y comprar, no poder colgarse en el comedor, el dormitorio o en la sala de exhibición. Así, una exhibición de pintura mural es prácticamente imposible, con excepciones. El tablero que les muestro es de Xavier Guerrero: decoraba el techo de una habitación en la casa del director de la Escuela Nacional de Agricultura, Marte R. Gómez. En los años sesenta esa casa fue demolida, y los murales fueron desprendidos y vueltos a montar en bastidores de fibra de vidrio; por eso hoy pueden exhibirse como si fueran cuadros muy grandes. Pero esa técnica no se podía usar en tiempos de Orozco, sus murales hubieran sido demasiado grandes para desprenderlos de todas maneras y además él no tenía el menor propósito de hacer algo así. Lo que hizo fue escribirle a su esposa, para que ella, a su vez, le solicitara a Tina Modotti la toma de algunas fotografías. Tina Modotti debía tomar fotos que mostraran los murales como parte de la arquitectura. En sus encuadres, era 
deseable que aparecieran las columnas, arcos e impostas de la Escuela Nacional Preparatoria, que era el edificio donde estaban los murales más importantes de Orozco.

Es posible que a pesar de la indudable calidad de las impresiones que recibió, Orozco tuviera dudas. Por eso exhibió otros materiales: bocetos de los murales, además de las fotografías. Hizo también otra cosa: una serie de litografías en las que reprodujo las fotografías de Tina Modotti. Esa reproducción llega a ser, a veces, muy exacta. Orozco no había hecho litografías previamente, que sepamos, aunque conocía otras técnicas de impresión. Había sido caricaturista, y en esa calidad había conocido una variedad de procesos, materiales, sustancias y herramientas para imprimir. En casi todos ellos se recurría al auxilio de la fotografía para obtener imágenes que luego se transferían a una plancha de metal, y que finalmente se imprimían. La litografía es distinta. En la litografía se dibuja sobre una piedra especial con un lápiz graso. La piedra se humedece. Luego se cubre con una tinta grasosa. Naturalmente, la tinta grasosa se adhiere al dibujo grasoso, pero no a las zonas libres de la piedra, que quedaron húmedas. La piedra se aplica sobre el papel utilizando un tórculo, y así se imprime.

Un resultado de este proceso es que los dibujos se imprimen en sentido inverso, como un espejo. Ignoro si fue por eso que hay dos series de litografías en algunos de los murales. Una de ellas tiene las estampas en el sentido correcto; la otra en sentido inverso. Orozco trabajaba con un impresor neoyorquino, George Miller, que había experimentado con técnicas comerciales para las artes; una de ellas era el offset. En el offset, como sabemos, la matriz se imprime sobre un rodillo intermedio, que luego deposita su imagen sobre el papel. De esta manera, al invertir la inversión, la imagen queda en el sentido original. Es bastante probable que Orozco y su impresor recurrieran a este medio. Sus propósitos son difíciles de adivinar: tal vez quisieron simplemente corregir la inversión. Es difícil aceptar que Orozco cometiera un error tan elemental. Tal vez se trató de un experimento.

En todo caso cada litografía tiene en la parte inferior izquierda un número serial que indica el tiraje total, en general de cien ejem- 
plares, y el número de la impresión. Cien al derecho, cien al revés. Esto fue, años después, motivo de enorme preocupación para el artista. Durante una estancia en Europa, unos años después, hizo otra litografía en un taller parisino. De acuerdo con las prácticas comerciales habituales, el taller (el Atelier Desjobert) imprimió el tiraje completo, le dio las copias numeradas a firmar al artista y posteriormente canceló la placa y la imprimió cancelada para certificar su destrucción. Orozco había hecho dos tirajes de la misma placa. Años después, le echó la culpa a su agente por ésta, que le comenzó a parecer una irregularidad.

Tenemos entonces por lo menos cuatro cosas que forman parte de manera compleja de la misma imagen. Las enumero en orden cronológico. Orozco hace bocetos de sus murales, aunque a veces a la hora de pintar cambia la imagen considerablemente. Esos bocetos se hacen en un papel casi siempre de calidad deleznable, y su supervivencia es motivo de muchos cuidados. Si se omiten los cuidados, los dibujos desaparecen pronto. Algunos de estos dibujos se exhibieron durante años en el Instituto Cultural Cabañas. Desafortunadamente, se exhibieron en salas que no tenían condiciones de clima controlado. Esto provocaba que los custodios abrieran las ventanas y los postigos de tanto en tanto, para permitir la circulación de aire. Con ello no sólo cambiaban de manera súbita las condiciones de humedad y temperatura alrededor de estos dibujos sobre papel mantequilla y albanene; además, entraba la luz solar directa. Estamos hablando de los años setenta y ochenta.

Después están los murales. Pero veamos: justo la imagen que he tomado como ejemplo, que la literatura llama "Mexican Peasant" o "Grief", viene de un tablero que comúnmente se llama "La trinidad". Los hijos de Orozco han insistido con frecuencia, con razón, en que su padre no les atribuía títulos a sus murales. Sin embargo, la práctica curatorial aceptada internacionalmente es usar el título del coleccionista, que en este caso puede ser doble. Los murales están en un edificio universitario. Su inventario, sin embargo, le corresponde por ley al Instituto Nacional de Bellas Artes. Cualquiera de los dos puede usar un título, y ambos serían en principio válidos. La práctica profesional de la curiaduría y la historia del arte está 
hecha, en este ámbito, de reglas que no siempre están escritas, aunque su uso es tan extenso que tienen el rigor de un estándar. Si yo le pongo el título al mural, si lo llamo "La trinidad", todo el mundo va a pensar que es el título atribuido por la Universidad, entre otras cosas porque el edificio se convirtió, en los años noventa, en museo. Hay más complejidad. Orozco cambió su mural. La primera versión, la pueden ustedes ver en esta foto, era distinta en varios detalles, entre ellos el que se reproduce en la litografía. Las dos versiones tienen generalmente el mismo título. Se distinguen con las expresiones "primera versión" y "segunda versión". La primera versión ya no existe, fue destruida para hacer la segunda versión.

Luego están las fotos. Fueron completamente utilitarias en el momento de su toma. Orozco las usó para mostrar sus murales y para hacer sus litografías. Fueron material de paso, transitorio, parecido a los archivos jpg que hoy bajamos de Internet, usamos y olvidamos. Pero son de Tina Modotti. Si las imprimió ella misma llevan una categoría especial: son "vintage". Todo lo que se refiere a sus derechos de autor lo administra un museo en Phoenix. ¿Son obras de arte? Esa pregunta la dejo pendiente para que la responda algún teólogo, yo no tengo una respuesta, aunque no podría negarse que reproducen, interpretan, retratan o muestran otras obras de arte. ¿Y su título, debe ser el del mural? ¿Tendrían un título propio? ¿Quién es el autor? ¿Sería justo atribuirle la imagen a Tina Modotti? ¿Si hiciéramos una base de datos, debería decir Modotti, Tina, o debería decir Orozco, José Clemente? ¿Debería decir "impresión en gelatina de plata" o debería decir "fresco"? ¿La fotografía difiere significativamente del fresco? Eso podría ser.

Les muestro este negativo de otra fotografía de otro mural. Me lo encomendó el fotógrafo tapatío Juan Víctor Arauz, que también me dio este pedazo de papel. El pedazo de papel tiene lo que los fotógrafos llaman "una mascarilla". Hace apenas quince años toda la fotografía era química. El negativo se colocaba sobre el papel en el cuarto oscuro, recurriendo a una amplificadora o directamente; este negativo es de ocho por diez pulgadas. El fotógrafo podía usar sus manos, o distintas mascarillas de cartulina o papel, para tapar la luz en algunas zonas y permitir la exposición mayor en otras. 
La mascarilla que les muestro la hicieron conjuntamente José Clemente Orozco y Juan Víctor Arauz. Orozco quería que sus murales aparecieran muy oscuros en las fotos, y Arauz tenía instrucciones precisas de imprimir siempre con la mascarilla. El historiador del arte Justino Fernández llegó a pedir una impresión un poco menos tenebrista, sin éxito. Me imagino que los negativos de Tina Modotti estarán en algún lugar, y no me sorprendería que algún día se encontrara una mascarilla o, simplemente, una hoja con indicaciones sobre luces y sombras. Vamos a imaginarnos algo más complejo, la fotografía lo es: negativo, una o varias copias del mismo, que pueden ser iguales o distintas entre sí merced a distintos procedimientos de impresión. Tremendo.

Ahora vamos a imaginarnos una ficha catalográfica de este objeto complejo. La ficha es muy importante y contiene varias cosas. Contiene, por un lado, las primeras ideas del pintor sobre un mural que cambió por lo menos una vez; contiene fotos de las dos versiones del mural; contiene por lo menos alguna referencia a las fotos que quería José Clemente Orozco; contiene las impresiones de Tina Modotti y, si lo encontramos, alguna indicación sobre el lugar en el que están los negativos. Si se conservan, incluye las instrucciones para la impresión del negativo. Incluye las cien copias de cada una de las impresiones litográficas; esto es: doscientas. Supongamos que hubo cinco bocetos para el mural y, por decir un número arbitrario, tres impresiones de las fotos (la que encargó Orozco, la que encargó Manuel Toussaint y se quedó en el Instituto de Investigaciones Estéticas, y una que se haya quedado la fotógrafa). Son tres, además del negativo y un posible documento que dirija la impresión; cinco. Debemos tomar en cuenta, además, la posibilidad (remota, pero se trata de ver el máximo posible) de que aparezca algún día la plancha litográfica. Tenemos además las dos versiones del fresco. Son un total de 213 cosas que se refieren a la misma imagen (no hemos tomado en cuenta a otros fotógrafos, sólo a Tina Modotti). Si hiciéramos un catálogo riguroso, cada una de esas 213 iteraciones, repeticiones o variantes de la misma imagen tendría un registro por separado. Sería importante referir todas las imágenes a un modelo ideal, "La trinidad revolucionaria"; pero también sería 
importante que es sólo uno de los tableros de la Escuela Nacional Preparatoria. Les aseguro una cosa: no es el caso más complejo que he visto en mi vida. Por lo menos aquí hay sólo un autor en cada etapa. Por lo menos aquí las técnicas pueden describirse con denominaciones convencionales.

Ahora pasemos a otra posibilidad, nada remota. Tanto la Universidad Nacional Autónoma de México como el Instituto Nacional de Bellas Artes van a inventariar el mural de acuerdo con sus propias nociones, y sobre todo de acuerdo con su propia legislación. Van a hacerlo poniendo en el centro una noción legal. Van a referirse al "patrimonio". El patrimonio es una noción que se refiere a la propiedad. El patrimonio era la parte de una herencia que no era posible enajenar o dividir, y que normalmente quedaba en poder del hijo varón mayor. Es una noción que viene del derecho romano, pero que se utiliza por lo menos desde el siglo XvIII, según los diccionarios de la Academia, para definir la pertenencia nacional: la patrimonialidad es la "calidad de ser originario de algún país, que da derecho para adquirir lo que sólo se debe dar a los naturales". Más claro ni el agua: "patrimonio" es una noción que se relaciona con las construcciones imaginarias, pero también legales, de la identidad. Estos murales son patrimonio universitario más allá de su condición legal. Generación tras generación de preparatorianos construyeron una parte muy significativa de su educación cívica y de su cultura general mediante la observación precisamente de estos frescos.

Por otra parte, existe en México una variedad cada vez más compleja de disposiciones legales sobre el patrimonio. En lo que respecta a los murales de Orozco, y como existe un decreto presidencial respecto a toda la obra de Orozco, éstos están sujetos a las disposiciones de la Ley General de Monumentos y Sitios Arqueológicos, Históricos y Artísticos, que le otorga al INBA facultades para investigar, preservar y difundir. Entre estas facultades, hay un artículo que le permite al INBA autorizar o no autorizar la reproducción de toda obra que sea parte del patrimonio en los términos de la propia ley. Todo esto lo refiero para indicar algo bastante grave. Nos referimos a una ficha de 213 registros para una misma 
imagen. Digamos ahora otra cosa. Las instituciones cuando son corporativas suelen ser muy celosas de sus derechos y facultades. No es frecuente que compartan su información o que trabajen en equipo. Supongamos que cada una de las instituciones, el INBA y la UNAM, decide hacer su trabajo apropiadamente, pero cada una por su lado. Cada una de ellas hará una ficha con 213 registros, por lo menos. Tendremos entonces 426 registros, referidos a un solo objeto, que serían resultado de una duplicación estricta. Y en este contexto sería muy sencillo que alguien se confundiera; digamos, que alguien llegara a la conclusión de que hay 426 obras que se llaman "La trinidad revolucionaria".

Suena como chiste pero es algo dramático, el anecdotario a este respecto sería extenso y muy alarmante. Quiero explorar ahora un camino distinto de las advertencias sobre lo que ocurre cuando no hay una catalogación apropiada, profesional y consensuada. Me quiero referir a los problemas que surgen cuando sí se emprende esa tarea, cuando sí hay catálogos. Voy a señalar tres problemas, y luego voy a reflexionar sobre la interdisciplina, que suena muy bien en los proyectos de desarrollo, pero que es en la realidad muy difícil de conseguir.

Comencemos por lo más sencillo. A diferencia de un libro, que lleva impreso el nombre del autor y la fecha de impresión, casi siempre confiables, las obras de arte están con gran frecuencia bajo sospecha. La atribución de autoría y de fecha son dos de los problemas más espinosos de la historia del arte. Digamos, para abreviar, que estos frescos, que datan de 1924 y se modificaron probablemente en 1926 (subrayo que esto es probable) se han fechado con frecuencia en 1922 y así por el estilo. Es fácil remediar el error cuando se recurre a las fuentes escritas, ya casi todas publicadas y en algunos casos reeditadas; pero el problema es que casi todas esas fuentes se van a referir al mural, a las fotos de Tina Modotti y a la litografía con títulos distintos en español, y además en otros idiomas. Hay dos formas de solucionar este problema. Por una parte, en muchos museos, sobre todo fuera de México, la autoridad del curador todavía es vigente, de manera que basta con saber-aunque no haya una indicación directa en el registro respectivo- que la lista de obras 
del Metropolitan Museum of Art, en lo que toca al arte moderno, está a cargo de una colega prestigiosa y confiable, para creer en sus atribuciones. A semejanza de lo que ocurre en las bibliotecas, donde un bibliotecario responsable se ha hecho cargo de las dudas o ha puesto entre corchetes lo que ha considerado dudoso, en muchos museos del mundo hay curadores que ejercen ese tipo de autoridad sobre sus inventarios y catálogos. Se trata casi siempre de curadores que tienen un doctorado en historia del arte. Aunque pueden equivocarse, su autoridad en materia de atribuciones suele ser uno de los criterios más importantes para designarlos.

En México la formación en historia del arte ha sido un poco distinta que en el resto del mundo. Ha habido desde hace años una licenciatura en la Universidad Iberoamericana, que durante años fue prácticamente la única. En la UNAM, los historiadores del arte nos formamos en la carrera de historia, lo cual determinó que nuestros análisis políticos y sociales fueran un poco más sofisticados, a veces también más farragosos, que los de otros colegas; pero también determinó que nuestra formación elemental en historia del arte fuera deficiente, en particular en lo que toca a la erudición de los objetos: el conocimiento de las técnicas, la erudición concreta sobre los artistas, la historia de las colecciones, las fuentes de autoridad. Pero este problema ha sido menos importante que otro. En efecto: hasta hace poco, la mayor parte de los curadores de arte moderno eran autodidactas. Probablemente por eso los métodos de trabajo tienen más valor cuando se explicitan: es un problema de confianza. En esas condiciones, un gremio que se ha formado mayoritariamente en la historia recurre a una de las herramientas más importantes de esa disciplina, al aparato crítico. Sin embargo éste se construye con gran solidez en las bibliografías, y con un menor grado de confiabilidad en las listas de obra.

Ahora voy a abandonar el tono de queja; los catálogos están mal, pero estamos haciendo algo al respecto. $\mathrm{Y}$ los problemas que se generan cuando se aborda este contratiempo son múltiples; los más importantes están relacionados con el carácter necesariamente interdisciplinario del catálogo. Aunque me faltaron algunas imágenes, podría seguir sumando sin parar: las fotografías de los restaurado- 
res, muy distintas de todo lo que he mostrado; las ocasionales que aparecen en la prensa; los planos del edificio. En fin: no es sólo que son muchos objetos y documentos de naturaleza muy distinta, a los que se suman objetos digitales a gran velocidad. Es que cada uno de ellos tiene relación con un saber diferente, y para eso los catálogos deberán ser, más que flexibles, fluidos. Este problema trasciende el uso de uno u otro sistema de etiquetado, y se inserta más bien en las definiciones de "interdisciplina".

No deja de ser gracioso, a este respecto, que con frecuencia se nos exhorte a la interdisciplina. Al levantar el inventario de una obra de arte común y corriente intervienen los historiadores del arte, pero también otros humanistas. A ellos se suman con frecuencia los restauradores y conservadores, quienes a su vez recurren a una variedad de saberes científicos. Utilizan esos saberes en forma totalmente pragmática e instrumental, de manera muy semejante a los instrumentos ópticos y radioactivos que los médicos han tomado de los físicos. De hecho, es frecuente que los cuadros sean metidos a los aparatos de imagenología médica. Hay otras líneas de trabajo relacionadas con la identificación de especies animales y vegetales en las imágenes, pero me quiero referir aquí a otro aspecto, que me parece más importante.

Las clasificaciones de las artes no son estáticas. Su propia polisemia y las frecuentes disputas que se generan acerca de ellas provocan movimientos constantes a su alrededor, cuando no en sus propias definiciones. En el largo plazo, han perdido una buena parte de su utilidad como explicaciones o herramientas para dividir el mundo. Utilizo un ejemplo: la noción de estilo. Era frecuente, en las fichas catalográficas de otra época, que se hablara del estilo de las obras inventariadas o catalogadas. Esta acepción de estilo se parecía un poco a las taxonomías de una biología un tanto anticuada, pues utilizaba herramientas morfológicas para clasificar y establecer cronologías. Las nociones de "estilo" han perdido para los historiadores del arte una buena parte de su consenso, y se ven ahora como herramientas anacrónicas. En cambio, las interpretaciones iconográficas han florecido en las últimas tres décadas, y a diferencia de los estilos, que buscaban generalizar, las iconografías 
van a lo concreto, así que ha sido perfectamente posible establecer diccionarios y vocabularios controlados para enumerar los símbolos en una imagen. Una de esas herramientas es Iconclass, un sistema de clasificación para el arte y la iconografía que existía antes de las computadoras, y que se generó originalmente en Holanda.

Las decisiones que se toman a este respecto tienen consecuencias de largo plazo. Los enfoques iconográficos suelen ser, por decirlo así, "culturalistas". Los teóricos de la iconografía más importantes del siglo xx, Aby Warburg y Erwin Panofsky, recurrieron con frecuencia a comparaciones que iban más allá de los límites del arte. Panofsky comienza su muy célebre texto Iconografía e iconología describiendo a un señor que se quita un sombrero en la calle, e interpretando ese gesto de saludo. Warburg establecía vastas comparaciones entre imágenes y textos literarios muy distantes en el tiempo, pero también por su origen y características: fotografías contemporáneas eran comparadas con imágenes clásicas o del Renacimiento. Warburg recopiló una variedad de imágenes de distintos orígenes que pensaba dejar ordenadas en el Atlas Mnemosyne. Dejó algunas descripciones en sus diarios, pero como el acomodo mismo de las imágenes quedó pendiente a su muerte -y no está claro que fuera a haber un acomodo definitivo- la historia de este artefacto se asemeja a la cábala: hay un arte combinatorio que propone distintas versiones de un texto impronunciable e imaginario. Significativamente, una de las compañías que controlan el diccionario Iconclass se llama Mnemosyne.

El punto es que un sistema o vocabulario controlado que se base en la iconografía forzosamente irá más lejos que las imágenes en una colección, y su objetivo será clasificar los objetos en un contexto cultural más amplio. Si este contexto puede definirse en forma universal es un asunto a debatir, y tengo para mí que no, al menos no para fines de clasificación. Sería difícil imaginar un vocabulario común, por ejemplo, entre la iconografía bíblica y la longeva tradición iconográfica mesoamericana. Podría haber un vocabulario que incluyera ambas tradiciones basado en un método de clasificación de las palabras, un catálogo faceteado que fuera, además, "híbrido". Sería interesante, pero no resolvería mucho el problema: la univer- 
salidad, tal como se definió en la postguerra europea, estaba conformada por el conjunto de las naciones europeas. El eurocentrismo de estos instrumentos es el resultado de un momento cultural muy peculiar, en el que los países europeos, devastados por la Segunda Guerra Mundial, habían además perdido sus colonias y requerían desesperadamente borrar las fronteras y enemistades históricas entre ellos. La "cultura universal" fue en este sentido la cultura europea: un sistema de analogías, no de diferencias, pero con límites definidos. Los problemas de esta supuesta universalidad comenzarían cuando quisiéramos llamar "emperadores" a los tlatoanis, "Estados" a los altépetl, "Confederación" al Hueytlatocáyotl, y sigue y suma. Los términos son equivalentes y la traducción es válida, pero una clasificación que tuviera como fundamento una equivalencia así se encontraría con problemas muy rápido. En cambio, hay propuestas razonables que permiten pensar en el conjunto de la iconografía mesoamericana como un universo con reglas comunes. Esto es: los sistemas clasificatorios pueden ser universales, siempre que pensemos en "universos" definidos de antemano y limitados.

No estoy diciendo, desde luego, que instrumentos como Iconclass sean inútiles para el arte mexicano. Por el contrario: la condición colonial provoca que, aunque problemática, ese uso sea perfectamente posible, sin demasiadas adaptaciones, para los objetos a partir de la conquista. Y hay algo más: existe un debate no resuelto sobre el lugar, origen y posible interpretación de los símbolos indios en las imágenes coloniales. Desafortunadamente, los artistas de aquel período no pensaron en la clasificación de sus obras y mezclaron lenguajes de acuerdo con sus intereses y condiciones, por lo que un vocabulario común, que tomara en cuenta las diferencias y las sistematizara de alguna manera, sería útil.

Pero no creo que lo más importante de este debate sean las diferencias entre culturas nacionales o continentales; en realidad ese debate es bastante rancio. En cambio, una clasificación o un diccionario culturalista obligarían a rebasar los límites de la historia del arte, y tendrían que incluir imágenes y otros dispositivos que originalmente no hayan tenido intenciones artísticas. Asumidamente, los sistemas más ambiciosos de clasificación cultural han aspirado 
a proporcionar herramientas para una historia de la cultura renovada, y no sólo para la historia del arte. Sería largo discutir si esta ruptura con la jerarquía, que le otorgaba al juicio estético de valor el lugar preponderante, sería una destrucción de la historia del arte en aras de la sociología, o una conquista de otras disciplinas por parte de la historia del arte.

Este problema está completamente vigente en las discusiones actuales entre la historia del arte y el resto de las disciplinas humanísticas y sociales, que significativamente utilizan las imágenes sin preocuparse gran cosa por sus datos elementales; algo impensable para las fuentes escritas de la historia. Existe una industria cultural del pasado: los canales especializados en la historia, las revistas de divulgación, las exposiciones masivas. Esta industria, que con frecuencia se utiliza políticamente, utiliza el poder de las imágenes para descentrar, incorporar discursos no explícitos, multiplicar las interpretaciones y establecer comparaciones insospechadas. Precisamente es reacia a la clasificación rigurosa porque le interesa lo contrario: activar la imaginación histórica rompiendo los límites de relatos que suelen ser opuestos: esquemáticos, poco imaginativos y secos. Una imagen sin datos de clasificación demasiado estrictos puede ayudar a construir una rica experiencia desde un pobre planteamiento.

Es frecuente que los colegas de otras disciplinas nos vean como oráculos, y que nos traten como si poseyéramos algún secreto para descifrar lo que se ve, al que suelen llamar "metodología". Como sabemos, la mayor parte de los chamanismos han recurrido a métodos para comunicarse con lo sobrenatural, mismos que con frecuencia incluyen el consumo de drogas psicodélicas. Lo que estamos buscando con la clasificación de imágenes y objetos que forman parte de la cultura es un poco lo contrario: establecer los fundamentos de un análisis sobrio y agnóstico, pero confiable. No estoy en contra de una interpretación imaginativa de las imágenes, pero sí me parece que la crítica requiere de un espacio específico para su tarea, que es siempre complementaria de la poesía.

Toda esta reflexión se refiere a la posibilidad de incluir, en las clasificaciones de obras de arte, algo semejante a los encabezados 
temáticos que suelen contener las bibliografías bien elaboradas. El problema no es menor. Si pensamos en un instrumento de Internet, desde luego la calidad de la clasificación es lo que permitirá distinguirlo de una multiplicidad de recursos de red que son más o menos confiables -a veces muy poco- pero que no tienen tras ellos criterios de calidad cultural, sino de productividad mercantil. Hay extensos bancos de imágenes que sí contienen una clasificación estricta, desde el punto de vista bibliotecológico o de las ciencias de la información; entiendo que este problema de la denominación es debatido. Sin embargo, rara vez contienen instrumentos conceptuales más allá del propio objeto digital del que se trate. El problema es común a otros productos de la cultura digital. Hay un debate que urge superar sobre la pertinencia del libro digital, sobre si reemplazará el olor, la textura y el color del papel. Es obvio que eso no podrá ser reemplazado, pero el debate no es ése sino, como lo plantea Robert Darnton con enorme urgencia, la construcción de bibliotecas con textos bien editados, revisados y clasificados. Esto es: la biblioteca digital distinta de Google que brinde textos legibles y confiables, no la fotocopiadora universal. Tal proyecto, expresado en forma muy categórica por aquel autor, requeriría del uso de fondos públicos para emprender vastos proyectos de libro digital que, entre otras cosas, impidieran la apropiación masiva de la memoria mundial.

Algo semejante ocurre con los sistemas de clasificación de las obras de arte. Aunque hay cada vez más sistemas en Internet que permiten ver las fotos, los cuadros, las postales, los planos y otros artefactos semejantes, no siempre esos sistemas vienen acompañados de protocolos que permitan su utilización crítica. En nuestro país es frecuente que los sistemas clasificatorios sean, además de domésticos, un poco ampulosos, y que busquen establecer alguna forma de taxonomía general de todas las formas, ya sea mediante la noción de "estilo" o recurriendo a alguna noción muy simplificada de "tipología". Pero es raro que esta clasificación de motivos se haya pensado desde alguna posición teóricamente rigurosa. No es que tales instrumentos sean inútiles, es que se llevan a cabo en forma aislada y sin recurrir a formatos, maneras de clasificación y 
vocabularios de consenso, por lo que su utilidad queda limitada a su propio universo, en el mejor de los casos. También es frecuente que estos sitios de Internet sean víctimas de la noción nebulosa de "multimedio", una supuesta revolución del conocimiento que no hace sino reunir en una pantalla los medios inventados al final del siglo XIX -como la estereoscopía.

Me parece que la clasificación de las obras y las imágenes debe dejar atrás el debate, ya bastante inútil, sobre el uso de la tecnología. También la máquina de escribir, el tarjetero de cartulina, las agujas y los catálogos faceteados en varios volúmenes eran, todos ellos, artefactos producto de una tecnología, y lo que parece es que las computadoras se han limitado a reproducirlos y ampliar su alcance. El debate es el mismo que con los ficheros, kárdex y cédulas: qué tan confiable es la información, qué tanta calidad tiene, qué tanto me ayuda a entender lo que estoy buscando. Si se trata de un libro digital, la pregunta principal nunca fue el peso del papel o el tamaño de la tipografía, sino el rigor en el cuidado del texto; así en los catálogos, pero de manera no muy estandarizada. Trato ahora de traer a colación discusiones que me parecen importantes. El problema con la clasificación de obras de arte es que, además de ser radicalmente polisémicas, las obras de arte son portadoras de imágenes, pero no son, ellas mismas, las imágenes. Son reproducibles, pero no son la reproducción. Y un sistema clasificatorio va a tener que vérselas con eso de manera también variada. ¿Se van a poder usar las etiquetas marc, el dublincore o cualquier otro sistema bibliotecológico para este fin? Mi opinión es que sí, pero no va a ser suficiente. Sí se necesita recurrir a instrumentos normalizados y sistematizados, pero no van a ser suficientes porque incluso el sistema muy sofisticado del VRA se creó para clasificar "recursos visuales" alrededor de las obras de arte, y no las obras de arte. Y como vimos en el caso del mural de Orozco, sería igualmente erróneo limitar la clasificación a las obras de arte mismas, pero no sería menos equivocado excluirlas, omitir su condición de objetos autónomos, y reducirlas a un sistema de información. Las obras de arte no son mera información lineal y cualquier intento de clasificación que las vea de esa manera va a fracasar. 


\section{Retos de la formación bibliotecológica en la sociedad red}

Hugo Alberto Figueroa Alcántara

Facultad de Filosofía y Letras, UNAM

\section{INTRODUCCIÓN}

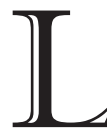

a educación de bibliotecólogos plantea innumerables desafíos de todo tipo y, sin duda, es un tema vasto y multifactoconsidera oportuno en la presente contribución abordar una serie de retos trascendentes que la formación bibliotecológica en la sociedad red tiene ante sí. Para ello se desarrollan tres apartados: el contexto de la sociedad red; los elementos críticos vinculados con la sociedad red y el universo de la información, y los retos de la formación bibliotecológica en la sociedad red.

\section{EL CONTEXTO DE LA SOCIEDAD RED}

En esta fase del devenir de la humanidad caracterizada por la preeminencia de la información, una de las características más notorias de la sociedad actual es la de la creciente globalización, que si bien tiene un sustento esencialmente económico, ha derivado en una interconexión, a escala mundial, de prácticamente todas las actividades humanas: económicas, políticas, sociales, culturales, científicas, tecnológicas y de comunicación, entre otras. 
Oportunidades y retos en la formación, investigación y aplicación...

Tal tendencia, a su vez, muestra múltiples evidencias de que diversas estructuras y elementos sociales, culturales, económicos, educativos, de información, digitales, etc., se están organizando en forma de redes (Berners-Lee, 2000), de ahí el concepto de sociedad red (Castells, 1999). Dicha morfología en red constituye una reconfiguración del modelo de nuestra sociedad vigente, además de que la propagación de su lógica de entrelazamiento modifica de manera crucial los procesos sociales y culturales dominantes pero también los alternativos, en todo el mundo y en todas las actividades humanas, por lo que esta dinámica tiene una repercusión notable en la interacción cotidiana, el poder, la información y la cultura, entre otras esferas.

En tal marco, los diversos vínculos entre individuos, comunidades y la sociedad en su conjunto (creados, recreados y reinterpretados en la interacción cotidiana) están definidos por una complejidad e interconectividad cada vez mayores, aspectos que a su vez reconfiguran radicalmente las características fundamentales de nuestra era y generan nuevos códigos, símbolos y significados, así como inéditas representaciones, prácticas y relaciones sociales y culturales (Melucci, 2001: 46-51).

Paralelamente este fenómeno de la globalización, tan acentuado y universal, ha estado estrechamente articulado con el nacimiento, desarrollo e impresionante impacto de un medio tecnológico y de comunicación que con el paso del tiempo y a nivel mundial se ha convertido en un elemento cardinal del tejido social y cultural de nuestras vidas: Internet. Una de las cualidades más sobresalientes del paradigma en que se basa Internet es su capacidad para conectar todo con todo (Berners-Lee, 2000) y distribuir el poder de la información por todos los espacios de la actividad humana, convirtiéndose así en la plataforma tecnológica y de comunicación del modelo de organización que caracteriza a la sociedad actual: la red, (Castells, 2001: 15).

El paradigma de la red tiene implicaciones en todos los campos del quehacer humano y se percibe un progresivo interés en su estudio desde perspectivas sociales, culturales y científicas, entre otras. Estos enfoques han dado lugar a conceptos relevantes como 
el ya mencionado de sociedad red (Castells, 1999; Cebrián, 2000), cultura de las redes (Joyce, 2001; Taylor, 2001; Kerckhove, 1999; Lévy, 2007), ciencia de las redes (Barabási, 2002; Buchanan, 2002; Watts, 2003; Strogatz, 2003), etcétera.

En esta conformación de la sociedad red, transitamos, en esencia, de una sociedad industrial basada en la producción de bienes materiales a una sociedad fundamentada en la producción de bienes de información. Los rasgos primordiales que se identifican en esta mutación son el decremento de la producción material y el aumento de la producción de información y signos culturales, (Melucci, 1989: 45).

De acuerdo con lo anterior podemos asegurar que vivimos una etapa de transición de la sociedad industrial a la sociedad red, también denominada sociedad del conocimiento o sociedad de la información, o bien, caracterizada por algunos de sus rasgos esenciales mediante conceptos como sistema mundo (Wallerstein, 2005), reflexividad y construcción de códigos simbólicos (Tejerina, 2004). En tal contexto, Internet es el emblema crucial de una serie de cambios vertiginosos en esta fase de la civilización humana, simbolizada por el poder y el valor estratégico de la información, de tal manera que también podemos concebir a la sociedad red como equivalente a la era de la información. Internet, al ser ya un elemento profundamente incrustado en el tejido social y cultural de nuestras vidas, ha provocado nuevas modalidades en nuestros estilos de vivir, convivir, trabajar, aprender, informarnos y relacionarnos. También ha generado una faceta inédita respecto a la percepción del espacio/ tiempo social, ahora caracterizado por redes, interconectividad, comunicación de muchos a muchos, complejidad y velocidad cada vez mayor de los flujos de información, (Castells, 2001: 15-17).

Existen diversos elementos que revelan la profunda trascendencia de Internet en todas las facetas de actividad humana y por ende su repercusión tan primordial en la configuración de la sociedad red. Entre otros, puede destacarse el empleo de tecnologías de carácter público, su modelo descentralizado y la cultura libertaria que desde sus inicios caracterizó a este medio. Internet es, sobre todo, un nuevo medio de comunicación eminentemente horizontal, que 
posibilita extraordinariamente el intercambio de ideas entre personas que conforman diferentes tipos de comunidades y redes sociales. A través de Internet, identificamos el surgimiento de un nuevo espacio social y cultural de alcance global, en el que conviven millones de personas de contextos sociales, culturales, políticos, económicos, etc., muy heterogéneos. Se trata de una nueva esfera de intercambio social que afecta de manera directa o indirecta a un porcentaje cada vez mayor de la población mundial y que está provocando la aparición de nuevas formas de sociabilidad, basadas en modelos de red, (Contreras, 2003: 26-27).

Entender estos modelos de organización, sistemas de intercambio de información, símbolos culturales, valores y creencias, basados en modelos de red, y dentro de este contexto, el papel cada vez más protagónico que juegan los nuevos movimientos sociales y las nuevas modalidades de identidades y acciones individuales y colectivas en el entorno de la sociedad red, puede aportarnos elementos valiosos de reflexión en relación con los retos a considerar en la formación de los bibliotecólogos en el entorno de la sociedad red, por lo que a continuación se profundiza en tales elementos críticos.

\section{ELEMENTOS CRÍTICOS VINCULADOS CON LA SOCIEDAD RED} Y EL UNIVERSO DE LA INFORMACIÓN

En la actualidad, dentro del contexto de la sociedad red, en el universo de la información ocurren múltiples fenómenos culturales, sociales, tecnológicos, políticos y económicos que, cualitativa y cuantitativamente, son muy diferentes al escenario previo de hace unos cuantos años; fenómenos interconectados que reconfiguran las modalidades de vivir y convivir en la sociedad red.

Así, dentro de la sociedad red, el universo de la información adquiere una importancia fundamental porque simboliza poder y ampliación de los signos sociales y culturales que definen el espíritu de nuestros tiempos, así como nuevas peculiaridades en nuestros estilos de vivir, convivir, trabajar, aprender, informarnos y relacionarnos en estructuras de red. Estas características del universo 
de la información en la sociedad red están asociadas con otros elementos emblemáticos de la vivencia y convivencia social y cultural de nuestros días, tales como Internet en su faceta comunicativa y constructiva de tejido social y cultural, las identidades y acciones individuales y colectivas, los nuevos movimientos sociales, la cultura hacker, los paradigmas de obsequiar, compartir y colaborar en la red, el ideal de la sociedad y cultura libres, los bienes comunes, las alternativas ciberculturales y el diálogo intercultural, entre otros tópicos de gran importancia, los cuales, al vincularse entre sí, definen los nuevos modelos de vivencia y convivencia en la sociedad red.

Sin duda, Internet se ha convertido en un elemento cardinal del tejido social y cultural de nuestras vidas, sobre todo por su cualidad inherente de conectar todo con todo y distribuir el poder de la información por todos los espacios de la vida humana. Nos queda claro que Internet es actualmente, ante todo, una plataforma, un nuevo medio de comunicación eminentemente horizontal, que posibilita extraordinariamente el intercambio de ideas entre personas que conforman diferentes tipos de comunidades y redes sociales, por lo que favorece novedosas formas de sociabilidad, basadas en modelos de red, así como nuevos movimientos sociales, (Castells, 2001).

Los nuevos movimientos sociales se caracterizan por una organización fluida y abierta, una participación multifacética y heterogénea y una mayor atención a las transformaciones sociales y culturales, más que a las económicas, por lo que posibilitan la creación de elementos culturales alternativos a los dominantes. Los nuevos movimientos sociales reflejan, ante todo, la edificación de identidades colectivas.

La identidad colectiva es un proceso de naturaleza cultural, social y psicológica, que vincula a los individuos con un grupo o comunidad a través de una serie de interacciones que tienen como eje primordial la actividad del movimiento social y los intereses en común, (Ayers, 2001). Sin duda en tal contexto un aspecto primordial del ser humano, que lo diferencia plenamente de otras especies, es su eterna lucha por el reconocimiento y por trascender, 
como podemos constatarlo a través del ejemplo emblemático de la cultura hacker.

La cultura hacker concebida como un nuevo movimiento social se basa en una identidad colectiva sustentada en una actitud crítica y libertaria ante el conocimiento y la información, una lucha por la democratización de la información, una perspectiva lúdica del trabajo en relación con otras actividades y una visión no convencional respecto al papel de las computadoras, las redes y todo tipo de tecnologías en la sociedad, para utilizarlas sobre todo como medios emancipatorios, (Himanen, 2004: 155-160).

El ideario ético y proyección social de la cultura hacker puede aplicarse a todo tipo de ámbitos disciplinarios, científicos, tecnológicos, educativos, sociales, laborales, etc., y refleja, más que nada, una actitud y posición ante la vida. La cultura hacker es ante todo un nuevo movimiento social conformado por identidades colectivas para realizar acciones colectivas en el marco de la sociedad red.

En la sociedad red el ideal de la sociedad y cultura libres adquiere una importancia crucial. Las ideas actuales de sociedad y cultura libres se sustentan en elementos fundamentales como son: democracia, libertad de expresión, libertad intelectual, acceso abierto a la información, información y bibliotecas, caracterizados como bienes comunes de información, preservación del patrimonio cultural en todas sus manifestaciones, creatividad, posibilidad de utilizar obras previas para crear otras, entre otros, (Hess, 2007a; Bollier, 2008; Stallman, 2002).

En tal contexto resulta primordial apreciar la importancia de los bienes comunes de información como uno de los componentes fundamentales para la construcción de una sociedad y cultura libres; reconocer la información, el conocimiento y los medios digitales como bienes comunes de información y promover la construcción de nuevas perspectivas, acciones, procesos educativos e investigación para fortalecer estos bienes comunes. Además este enfoque de bienes comunes ofrece nuevas perspectivas que nos permiten concebir la información y el conocimiento como bienes compartidos, (Figueroa, 2011). 
En nuestro ámbito de acción bibliotecológica los bienes comunes de información tienen una importancia crucial porque representan una respuesta y alternativa viable a los modelos cada vez más restrictivos y asfixiantes de los derechos de autor, la propiedad intelectual, la apropiación abusiva de espacios y bienes públicos, etc., visibles en el sistema capitalista vigente, a la vez que permiten reunir, bajo un concepto general, una gama muy amplia y heterogénea de iniciativas de gran valor en el universo de la información, (Hess, 2007).

Las tendencias de vivencia y convivencia en la sociedad red se vinculan a su vez con paradigmas ciberculturales (Bell, 2000), los cuales repercuten de manera notable en la información que se genera, la velocidad a la que circula, su difusión a escala planetaria y, sobre todo, en una mayor apertura para confrontar ideas e incluir en la agenda global temas prioritarios tales como la democracia, los derechos humanos, la tolerancia y los encuentros y desencuentros entre diferentes culturas y visiones del mundo, elementos que en conjunto multiplican las posibilidades de un diálogo intercultural, (Mílovic, 2004).

Para desarrollar acciones contundentes en el entorno de la sociedad red, la formación de bibliotecólogos requiere cambios sustanciales en su visión y compromiso académico y profesional.

\section{RETOS DE LA FORMACIÓN BIBLIOTECOLÓGICA}

EN LA SOCIEDAD RED

Con base en el contexto ofrecido en los dos apartados previos, a continuación se exponen un conjunto de retos que la formación bibliotecológica en la sociedad red debe afrontar con el propósito de fortalecer las modalidades y alternativas de vivencia y convivencia en esta nueva fase de la civilización humana. Para ello se aborda con profundidad el tema del compromiso social del bibliotecólogo, así como el tipo de acciones que puede realizar en bien de las comunidades.

En relación con el compromiso social del bibliotecólogo, un punto de partida absolutamente trascendental y determinante que debe 
inculcarse íntegramente en nuestra formación es que, como bibliotecólogos, asumamos plenamente nuestra responsabilidad como actores sociales y hagamos trabajo comunitario, basado en los modelos de redes sociales, en beneficio de nuestras comunidades de todo tipo; un trabajo bien entendido, propositivo y positivo que coadyuve en la construcción de un mundo mejor, más tolerante, justo e intercultural, estableciendo una serie de acciones que posibiliten el bien común, la consolidación de bienes comunes de información, la sana convivencia y el intercambio abierto y sin restricciones de información y conocimiento a través de múltiples modalidades, por lo menos en nuestro radio de alcance, pero si estas acciones se interconectan con otras similares ganaremos mucho en cuanto a impacto local/global.

Es fundamental destacar también que, dentro del universo social de la información, las actividades profesionales que realizamos para localizar, examinar, interpretar, organizar y difundir la información nos colocan en una posición privilegiada con respecto a otros, desde aquellos que no cuentan con los medios necesarios para tener acceso a la información, hasta quienes sí los poseen, pero carecen de elementos para analizar y comprender los contenidos. Por tal motivo, a partir de nuestra posición y función social, tenemos la posibilidad de emprender acciones que favorezcan los procesos de construcción de identidad y de movimientos sociales a favor de una sociedad más abierta, plural, democrática e intercultural, (Figueroa Alcántara y García Durán, 2006: 131).

A partir de estas premisas se explican a continuación algunos tópicos cruciales que es indispensable considerar en la formación del bibliotecólogo.

Ante todo para lograr resultados positivos los bibliotecólogos debemos desarrollar una sensibilidad eminentemente social y comprometernos a servir a nuestras comunidades para que estén cada vez más interconectadas, sean cada vez más interculturales y tengan acceso a la información de múltiples maneras. Sin esa visión y ese compromiso no lograremos acciones políticas, sociales y culturales trascendentes y las diversas comunidades no se sentirán consideradas, no se fijarán metas y finalmente no invertirán recursos para 
desarrollar colecciones y servicios de información adecuados a sus entornos, (Larsen, 2004: 12).

Debemos promover en nuestras comunidades mecanismos para constituir, desarrollar y mantener estrategias y contenidos alternativos al mercado de las industrias de información prevalecientes, además de consolidarnos como actores relevantes en el universo de la información.

Es necesario aprender a actuar colectiva y colaborativamente para resolver la multitud de problemas relacionados con la información, así como para defender la idea del acceso libre, gratuito y sin restricciones a ella, los bienes comunes de esta información y los intereses de las comunidades en diferentes temas decisivos. Pero no podemos actuar solos o en el vacío, por lo que necesitamos extender nuestras redes de colaboración mutua más allá de las bibliotecas, e incluir el espectro completo de creadores, gestores y usuarios de los recursos de información.

Asimismo es fundamental explorar nuevas modalidades para compartir la información mediante nuestra participación en iniciativas como acceso abierto; bienes creativos comunes; repositorios institucionales; la creación, desarrollo, organización, difusión y preservación de información basada en la comunidad; las comunidades de aprendizaje e información, etc., y tendremos que involucrar a las partes interesadas en el diseño, la creación y el manejo autoregulado de estos sistemas.

También es fundamental que participemos activamente en las esferas públicas, ideológicas, legales y en el discurso político para promover el valor y beneficios de los bienes comunes de información, y alertar sobre los peligros de las restricciones que existen al respecto, (Kranich, 2007: 104-105).

Para consolidar e irradiar nuestra colaboración social y cultural a favor del bien común en materia de información, resulta esencial que concibamos y articulemos a las bibliotecas y otras unidades de información como bienes públicos y comunes de información, y como instituciones sociales y culturales basadas en la acción colectiva, que no sólo protegen la información, las ideas y los conocimientos, sino que facilitan su creación, intercambio, preservación y 
sostenibilidad. Uno de nuestros más grandes retos es educar a todo tipo de personas, y educarnos a nosotros mismos, acerca de los beneficios del acceso abierto y de los bienes comunes de información.

Es crucial crear nuestras propias comunidades de aprendizaje y redes sociales para mantenernos al día sobre las nuevas tendencias respecto a los bienes comunes de información y comunicar sus implicaciones al público para fomentar el diálogo, la participación y la colaboración; y de esta manera contribuir así al fortalecimiento de la sociedad y la cultura libres y a construir un mundo donde haya mayores y mejores alternativas de vivencias y convivencias en la sociedad red.

Hay que generar, tanto desde la docencia como desde la investigación, una visión más amplia del quehacer bibliotecológico en la sociedad red, a través de temáticas específicas que se puedan tratar a través de cursos, conferencias, ponencias, tesis, proyectos de investigación, etc.; doy como ejemplo las siguientes temáticas:

* Repercusiones sociales y culturales de Internet, como plataforma tecnológica y comunicacional emblemática de la sociedad red. El papel de los nuevos movimientos sociales en la conformación de alternativas de creación, organización, acceso y difusión de la información y el conocimiento.

Construcción de identidades individuales y colectivas en la sociedad red.

Los efectos de la cultura y ética hacker en el libre acceso a la información y en el desarrollo de bienes comunes de información.

* Paradigmas para colaborar y compartir información y conocimiento en la sociedad red.

* La importancia de los bienes comunes de información para una sociedad y cultura libres.

La ética de la información en la sociedad red.

El rol de la cibercultura en los modelos de vivencia y convivencia en la sociedad red, así como en la evolución de la civilización humana.

La trascendencia de las bibliotecas y el acceso a la información como medios para promover la diversidad cultural y la interculturalidad. 
Tendencias y aplicaciones de la web 2.0 y de la biblioteca 2.0 como plataformas cruciales para compartir y colaborar en el entorno de la sociedad red y promover el marco conceptual y las acciones para crear bienes comunes de información.

* El estudio y análisis de las bibliotecas, la información y el conocimiento como bienes comunes de información.

En síntesis, tenemos retos muy complicados por vencer, pero con compromiso social y un enfoque educativo que tenga como eje fundamental el bien común y el trabajo comunitario, podremos desempeñar un papel cada vez más trascendente dentro de la sociedad red.

\section{REFERENCIAS}

Ayers, Michael D. (2001), CollectiveIdentity.org: collective identity in online and offline feminist activist groups, Thesis, Masters of Science in Sociology, Faculty of Virginia Polytechnic Institute and State University, [en línea] http://scholar.lib.vt.edu/theses/available/etd-06112001-151759/unrestricted/thesis_final.pdf Consulta: 10 de diciembre de 2009.

Barabási, Albert-Lászlo (2002), Linked: the new science of networks, Cambridge, Perseus.

Bell, David y Barbara M. Kennedy (2000), The cybercultures reader, London, Routledge.

Berners-Lee, Tim (2000), Tejiendo la red, Madrid, Siglo XXI.

Bollier, David (2008), Viral spiral: how the commoners built a digital republic of their own, New York, The New Press.

Buchanan, Mark (2002), Nexus, New York, W.W. Norton.

Castells, Manuel (1999), La sociedad red, México, Siglo XXI.

Castells, Manuel (2001), La galaxia Internet: reflexiones sobre internet: empresa y sociedad, Barcelona, Areté.

Cebrián, Juan Luis (2000), La red, Madrid, Santillana, Suma de Letras. Contreras, Pau (2003), Me llamo Kohfam: identidad hacker, una aproximación antropológica, Barcelona, Gedisa. 
oportunidades y retos en la formación, investigación y aplicación...

Figueroa Alcántara, Hugo Alberto (2011), "La importancia de los bienes comunes de información para una sociedad y cultura libres”, en Jaime Ríos Ortega (coordinador) y César Augusto Ramírez Velázquez (compilador), $7^{\circ}$ Seminario Hispano Mexicano de Investigación en Bibliotecología y Documentación: memoria, unAM, Centro Universitario de Investigaciones Bibliotecológicas, pp. 597-611.

Figueroa Alcántara, Hugo Alberto y Samira García Durán (2006), "Vivencia y convivencia en el universo editorial y de la información”, en Hugo Alberto Figueroa Alcántara y César Augusto Ramírez Velázquez (coordinadores), Recursos bibliográficos y de información, México, unam, Facultad de Filosofía y Letras, Dirección General de Asuntos del Personal Académico, pp. 95-139.

Hess, Charlotte y Elinor Ostrom (2007), "Introduction: an overview of the knowledge commons", en Charlotte Hess y Elinor Ostrom (editores), Understanding knowledge as a commons: from theory to practice, Cambridge, Massachusetts, The MIT Press, pp. 3-26.

Hess, Charlotte y Elinor Ostrom (2007a) (editores), Understanding knowledge as a commons: from theory to practice, Cambridge, Massachusetts, The MIT Press.

Himanen, Pekka (2004), La ética del hacker y el espíritu de la era de la información, Barcelona, Ediciones Destino.

Joyce, Michael (2001), Othermindedness: the emergence of network culture, Ann Arbor, The University of Michigan Press.

Kerckhove, Derrik (1999), Inteligencias en conexión, Barcelona, Gedisa.

Kranich, Nancy (2007), "Countering enclosure: reclaiming the knowledge commons", en Charlotte Hess y Elinor Ostrom (editores), Understanding knowledge as a commons: from theory to practice, Cambridge, Massachusetts, The MIT Press, pp. 85-122.

Larsen, Jens Ingemann, Deborah L. Jacobs y Ton van Vlimmeren (2004), Multiculturalidad en la biblioteca: cómo pueden servir las bibliotecas públicas a las poblaciones multiculturales, Barcelona, Fundación Bertelsmann.

Lessig, Lawrence (2004), Free culture: how big media uses technology and the law to lock down culture and control creativity, 
New York, Penguin Press [en línea] http://www.free-culture.cc/ freeculture.pdf Consulta: 10 de diciembre de 2009.

Lévy, Pierre (2007), Cibercultura: la cultura de la sociedad digital, Barcelona, Anthropos; México, UAM, Unidad Iztapalapa.

Melucci, Alberto (1989), Nomads of the present: social movements and individual needs in contemporary society, Philadelphia, Penn, Temple University Press.

Melucci, Alberto (2001), Vivencia y convivencia: teoría social para una era de la información, Madrid, Trotta.

Mílovic, Míroslav (2004), Comunidad de la diferencia, Granada, Universidad de Granada.

Stallman, Richard M. (2002), Free software, free society: selected essays of Richard M. Stallman, Boston, Massachusetts, GNU Press. Strogatz, Steven (2003), Sync: the emerging science of spontaneous order, New York, Hyperion.

Taylor, Mark C. (2001), The moment of complexity: emerging network culture, Chicago, The University of Chicago Press.

Tejerina, Benjamín (2004), Multiculturalismo, movilización social y procesos de construcción de la identidad en el contexto de la globalización [en línea] http://www.ces.fe.uc.pt/publicacoes/oficina/187/187.pdf Consulta: 10 de diciembre de 2009.

Wallerstein, Immanuel Maurice (2005), Análisis de sistemas-mundo: una introducción, México, Siglo XXI.

Watts, Duncan J. (2003), Six degres: the science of a connected age, New York, W.W. Norton. 



\title{
La experiencia en la formación de posgrado en archivística en Colombia ${ }^{1}$
}

\author{
Ruth Helena Vallejo ${ }^{2}$ \\ Universidad de La Salle, Colombia
}

olombia ha avanzado mucho en la inclusión del tema de los
archivos en la agenda política, hecho que se ha reflejado
en el establecimiento de políticas públicas para el área, la
reglamentación de la profesión archivística y la formación de pro-
fesionales en todos los niveles educativos: técnicos, tecnológicos
y profesional universitario, lo que le permite contar con una base
sólida, aunque pequeña, de recursos humanos capacitados para
responder a la urgente necesidad de organizar, recuperar y preser-
var los documentos.
Sin embargo aún son diversas las dificultades que se deben en-
frentar, mencionaré algunas: la necesidad de alinear la gestión do-
cumental y el gobierno en línea proveyendo mejores prestaciones
para los ciudadanos, incluyendo el acceso a la información pública;
la especialización de muchos profesionales de otras áreas que por
diversos motivos están actualmente liderando proyectos archivís-

1 Este documento está basado en el libro de Registro Calificado de la Maestría elaborado por el Comité Curricular del Programa de Sistemas de Información, Bibliotecología y Archivística.

2 Actualmente Directora del Programa de Sistemas de Información, Bibliotecología y Archivística. rvallejo@lasalle.edu.co. 
ticos; el logro de un reconocimiento profesional y una identidad propia que deslinde la archivística de la bibliotecología; la responsabilidad universitaria de establecer, dentro de los perfiles profesionales y laborales, la opción de archivos sin que los currículos reflejen realmente una formación archivística, independientemente del enfoque de cada institución; la necesidad de enfrentar el gran desconocimiento del papel que juegan los archivos en la sociedad actual y su representación social como un elemento indispensable en el ciudadano del común; la búsqueda de soluciones interdisciplinarias a dificultades como la corrupción; la lucha por la defensa de los derechos humanos; la disminución de la brecha relacionada con el acceso a la información; la búsqueda de la transparencia que encuentra en los archivos desorganizados una fuente clara para su surgimiento.

Es por ello que la formación profesional de archivistas se convierte en una preocupación de muchos sectores en su afán por dar una respuesta adecuada al desarrollo que reclama la profesión, teniendo en cuenta para ello los referentes del entorno y las necesidades del mercado, para responder a una sociedad que demanda de ellos y de su ejercicio competente, perfiles adecuados para desempeñarse en los diferentes tipos de archivos.

La experiencia que ha tenido la Universidad de La Salle (ULS) es reconocida desde hace más de tres décadas y aunque en los inicios de la formación profesional no había una demanda alta para el programa, con el paso del tiempo se ha ido constituyendo en una excelente opción para el fortalecimiento y profundización de quienes se desempeñan laboralmente en la gestión y administración de archivos, así como en proyectos de implementación y administración de sistemas de información y en programas de gestión de documentos impresos y electrónicos. Actualmente el programa ha cambiado el perfil de ingreso y hoy se reciben jóvenes cuyas edades no superan los 20 años; es evidente que la mayor motivación se debe a las ofertas de empleo en el campo o al crecimiento profesional en su lugar de trabajo, y es claro también que en Colombia el mercado laboral es mayor en oportunidades y salario para los archivistas que para los bibliotecólogos. 


\section{La experiencia en la formación de posgrado en archivística en ...}

De esta manera el desarrollo archivístico de la ULS ha estado ligado por un lado a las tendencias del campo disciplinar, a partir de las necesidades del país, y por el otro al desarrollo de las tecnologías de la información y la comunicación y sus efectos sobre los archivos de las instituciones; en este proceso se ha buscado siempre la convergencia entre la solución a dichas necesidades y las posibles aplicaciones en los diferentes contextos de la realidad colombiana. Disciplinas como la administración, la informática, el derecho y la sociología han sido consideradas e incorporados sus avances en la actualización de las diferentes propuestas formativas sin perder de vista la evolución de las prácticas profesionales procedentes de otros países como Estados Unidos, Canadá, España, Francia y Australia.

Por ello hemos venido sufriendo cambios progresivos conforme al desarrollo mismo de la disciplina y de la sociedad, así como con la necesidad de las organizaciones públicas y privadas de hacer frente al aumento de la complejidad en organizaciones de todo tipo que requieren cada vez el diseño y el ofrecimiento de ofertas que permitan mejorar la formación profesional de los archivistas, de manera que puedan éstos responder a las exigencias del entorno en el que se desenvolverán en el futuro próximo.

Hasta 1995 en la Universidad solamente funcionaba el programa de pregrado; en 1996 se aprueba la apertura del primer programa de posgrado en Archivística denominado "Especialización en Sistemas de Información y Gerencia de Documentos" de un año de duración, y en febrero de 2011 se abrió la primera Maestría en el área de archivos del país, denominada "Gestión Documental y Administración de Archivos", iniciativa que indudablemente consolidará el compromiso que tiene La Salle con el patrimonio documental del país y con la formación en el área.

Desde sus comienzos el programa de pregrado ha ofrecido una doble formación tanto en bibliotecología como en archivística tratando de hacer un plan de estudios equilibrado de manera que las dos disciplinas tengan su línea de profesionalización, representada por los espacios académicos exclusivos de cada área, que en el caso de la archivística son: instituciones y documentos, descripción archivística, 
evaluación documental, gestión documental, archivos y sociedad, y gestión de documentos electrónicos, asimismo el área fundamentadora no sólo aporta a los conocimientos teóricos de la archivística sino a temas comunes de ambas disciplinas tales como derecho a la información, usuarios, fuentes de información, servicios y productos de información, entre otras. Igual sucede con el área complementaria en que se aporta tanto la formación administrativa y de gestión, así como en ciencias sociales y tecnologías de la información.

El perfil de los archivistas que busca formar la Universidad de la Salle es integral en la medida en que responde a las necesidades de la sociedad colombiana, pero tambien a los procesos evolutivos de la archivística como disciplina científica, con habilidades para involucrarse en entornos laborales diversos y con competencias para el desarrollo de proyectos archivísticos de diferente naturaleza, así como en procesos de investigación complejos acerca de su realidad y su entorno.

\section{ELEMENTOS MÁS SIGNIFICATIVOS DEL NUEVO PROGRAMA}

Fueron diversas las razones que se consideraron para iniciar esta propuesta:

* La oferta de personal calificado para desempeñar diferentes funciones y roles en los archivos en plena sociedad de la información no cubre las necesidades mínimas del país en este aspecto.

* La mayoría de las empresas, tanto públicas como privadas, medianas y grandes, cuenta con archivos para apoyar el desarrollo de sus actividades.

Las políticas del Gobierno en el sector de los archivos, la presencia de fenómenos como el acceso libre a la información y el ejercicio del control ciudadano, así como las tecnologías de la información y la comunicación, están modificando aceleradamente la forma como las organizaciones y los individuos acceden y usan la información.

La escasez de recursos humanos calificados en el campo de la archivística tiene serias implicaciones en el desarrollo del país, y 
esto agrava los problemas de subdesarrollo y genera sobrecostos innecesarios para las organizaciones, los cuales derivan, a su vez, en el aumento del déficit fiscal, el aumento de la corrupción, la pérdida de la memoria colectiva de la nación y la disminución de las oportunidades de acceso a los bienes de capital mundial y de bienestar para muchos conciudadanos.

El potencial laboral que existe en Colombia para los profesionales en Archivística se refleja en las aproximadamente 150.000 entidades públicas y privadas que cumplen funciones públicas, y las más de 10000 medianas y grandes empresas que hay en el país, las cuales no cuentan en su mayoría con personal profesional y que son sujeto del cumplimiento de la Ley General de Archivos, Ley 594 de 2000.

* El reconocimiento que para mejorar la competitividad de las empresas es necesario contar con información primaria y secundaria conservada en los archivos institucionales, cuyo acceso sólo es posible si se encuentran debidamente organizados y las empresas cuentan con sistemas de gestión documental altamente tecnificados que aprovechen los beneficios de las tecnologías de la información.

* La oportunidad de que los egresados de la Especialización en Sistemas de Información y Gerencia de Documentos puedan continuar el ciclo formativo en esta Maestría.

Las posibilidades de realizar un tránsito pregrado-posgrado a través del Programa de Sistemas de Información, Bibliotecología y Archivística.

Contexto de partida

Los lineamientos y horizontes de sentido que ofrece el Proyecto Educativo Universitario Lasallista son el marco central en torno al cual la Maestría en Gestión Documental y Administración de Archivos (MGDAA) articula docencia, investigación y proyección social para la formación integral de maestrantes capaces de analizar, interpretar e incidir en la realidad social, cultural y política en la que 
se desarrolla el sistema conformado, basado en Rendón (2008) por lo que toca a la información, los documentos, los usuarios y los archivos, entendidos como Instituciones Informativas documentales.

Dicho tipo de realidad aborda, desde los archivos y la gestión documental, problemáticas como la democratización del conocimiento, la participación ciudadana, la preservación del patrimonio documental y el acceso a la información como un derecho humano fundamental, elementos que configuran mecanismos de inclusión en una sociedad democrática.

Por ello el objeto de estudio de la Maestría se enfoca en dos elementos: los archivos y el documento archivístico; en cuanto al primero, la MGDAA se centra en el uso y aplicación de modelos administrativos para la gestión y dirección de archivos y proyectos archivísticos, el valor social de los archivos y la aplicación de las tecnologías de la información en los diferentes procesos de la función archivística; en cuanto al documento archivístico, éste es abordado como producto y co-producto de la administración y por lo tanto con un elemento consustancial a la dinámica de la gestión empresarial y como un recurso de información útil para el desarrollo de cualquier negocio.

Es así como se plantea como perfil disciplinar el que un maestrante sea competente para gerenciar proyectos empresariales en Gestión Documental, en instituciones públicas, privadas, organizaciones no gubernamentales y organismos internacionales. Sus conocimientos específicos le permiten dirigir procesos de planeación, gestión y seguimiento de los programas y políticas de desarrollo empresarial en gestión documental y administración de archivos. Desde el conocimiento teórico, fundamenta conceptos, teorías y alternativas de investigación en el manejo documental en la empresa moderna, a partir de una visión crítica e interpretativa de la memoria documental empresarial.

Se establecieron como Competencias disciplinares:

Aplica apropiadamente los fundamentos que orientan la práctica archivística, su desarrollo y aplicación.

- Integra y aplica conocimientos y técnicas de la gestión documen- 


\section{La experiencia en la formación de posgrado en archivística en ...}

tal para lograr el acceso a la información como instrumento de desarrollo y equidad.

* Gestiona información, documentos, servicios y archivos con criterios de transparencia para mejorar los niveles de productividad y eficiencia de la administración.

* Comprende la gestión documental y la administración de archivos apoyado en tecnologías de la información para lograr la gestión socialmente responsable de los archivos.

El tejido de relaciones entre ejes curriculares, núcleos y áreas, con fundamento en la persona, da como resultado la malla curricular de la Maestría. Tres son los ejes en los que gravita la apuesta curricular: "Problemas y prácticas", que se nutre de la identificación y estudio de las necesidades del entorno de la sociedad y del sector empresarial, reconociendo prácticas y problemas relacionados con las limitantes de las personas y grupos para la generación, apropiación y utilización de la información archivística, en una sociedad donde el conocimiento se coloca en el centro de la vida social y económica del planeta; "Ciencias y disciplinas", donde se concibe el conocimiento de la gestión documental y archivística, enmarcado dentro de las perspectivas epistemológicas de las ciencias sociales, en un enfoque integral en el que confluye la aplicación de una variedad de métodos empleados en diversas disciplinas, que propician soluciones a las problemáticas de los archivos de forma interdisciplinaria; e "Investigación", donde se ubican las líneas de investigación y la praxis investigativa mediante las cuales se desarrollan las competencias, y se aporta a la solución de problemas al generar conocimiento con impacto social y científico.

La articulación de estos tres ejes permite definir los núcleos (intencionalidad formativa) y las macro competencias de la malla curricular, en coherencia con la política institucional del desarrollo humano integral y sustentable. Tales macro competencias se derivan de los perfiles y competencias generales y particulares del programa de Maestría. Con estos dos referentes (núcleos y competencias) como marco de la malla curricular, se van ubicando dentro de cada ciclo los espacios académicos procurando articular la teo- 
ría con la práctica, la investigación con la formación, y los problemas concretos de la sociedad con la generación de conocimiento y los niveles educativos. Todo ello permite la correlación de procesos, la integralidad del currículo y la forma como la Maestría contribuye a la transformación social mediante el desarrollo de competencias de sus estudiantes y la generación de conocimiento oportuno y coherente con las situaciones reales del mundo.

\begin{tabular}{|c|c|c|}
\hline $\begin{array}{l}\text { Ejes } \\
\text { Curriculares }\end{array}$ & $\begin{array}{l}\text { Eje } \\
\text { Problemas } \\
\text { y Prácticas }\end{array}$ & $\begin{array}{l}\text { - Ineficiencia de la administración derivada de la } \\
\text { sobreproducción de documentos y la desorganización } \\
\text { - Impacto del uso de las tecnologías de la información } \\
\text { y la comunicación en la producción, gestión, acceso y } \\
\text { conservación de documentos de archivo. } \\
\text { - Preservación de la memoria corporativa en un } \\
\text { mundo dominado por las nuevas tecnologías de } \\
\text { la información. Dificultades para la recuperación y } \\
\text { acceso a la información y los documentos de archivo, } \\
\text { como apoyo a la toma de decisiones y la gestión } \\
\text { del negocio. } \\
\text { - Pérdida de la información electrónica por falta } \\
\text { de sistemas de organización, clasificación y } \\
\text { recuperación adecuados. } \\
\text { - Falta de reconocimiento de los archivos como centros } \\
\text { y recursos de información para la investigación. }\end{array}$ \\
\hline
\end{tabular}

Producto de la articulación de los ejes curriculares, el Programa define la intencionalidad formativa para los diferentes períodos académicos a través de los siguientes núcleos, mediante los cuales se representa la participación de la investigación y de las estrategias de aprendizaje en una problemática social concreta, y la manera como se genera conocimiento pertinente: 
La experiencia en la formación de posgrado en archivística en ...

\begin{tabular}{|l|l|}
\hline \multirow{2}{*}{$\begin{array}{l}\text { Núcleos } \\
\text { Curriculares }\end{array}$} & $\begin{array}{l}\text { Núcleo 1. Sistema en el cual interactúan información, documento, } \\
\text { usuario y archivo con miras a facilitar el acceso y preservación de la } \\
\text { información con criterios de responsabilidad social. }\end{array}$ \\
\cline { 2 - 2 } & $\begin{array}{l}\text { Núcleo 2. Herramientas y metodologías para la gestión y el tratamiento } \\
\text { de los documentos de archivo en diferentes soportes. }\end{array}$ \\
\hline
\end{tabular}

\section{Los contenidos y prácticas seleccionadas se organizan en tres áreas curriculares:}

\begin{tabular}{|c|c|c|}
\hline \multirow{3}{*}{$\begin{array}{l}\text { Áreas } \\
\text { Curriculares }\end{array}$} & Fundamentación & $\begin{array}{l}\text { Se busca profundizar en los conceptos y } \\
\text { metodologías para el diseño, implementación } \\
\text { y administración de un sistema de gestión } \\
\text { documental, abordando aspectos propios de la } \\
\text { disciplina e integrando nuevos contenidos de } \\
\text { aprendizaje con el fin de ofrecer una formación } \\
\text { actualizada de alto nivel profesional. }\end{array}$ \\
\hline & Profundización & $\begin{array}{l}\text { Ofrece los conocimientos necesarios para el } \\
\text { estudio de la estructura informacional de las } \\
\text { organizaciones, sus flujos de información, } \\
\text { la gestión por procesos y el diseño e } \\
\text { implementación de herramientas que permitan } \\
\text { la adecuada administración de los documentos } \\
\text { producto de las funciones empresariales. } \\
\text { Esta área busca brindar a los maestrantes los } \\
\text { elementos necesarios y suficientes para el } \\
\text { adecuado tratamiento y organización de los } \\
\text { archivos físicos y electrónicos, al igual que } \\
\text { ofrece una visión de los propios archivos. }\end{array}$ \\
\hline & Complementaria & $\begin{array}{l}\text { Esta área ofrece los conocimientos } \\
\text { complementarios para asegurar una formación } \\
\text { integral de los maestrantes desarrollando } \\
\text { competencias interdisciplinarias que los } \\
\text { habiliten para solucionar los problemas de su } \\
\text { entorno. }\end{array}$ \\
\hline
\end{tabular}


La formación investigativa está articulada al currículo de la Maestría a través de diferentes espacios académicos que le permiten al futuro maestrante desarrollar y adquirir los conocimientos, saberes (epistemológicos y metodológicos) y destrezas requeridas para comprender, interpretar y transformar los fenómenos objeto de su interés científico, así como para orientar su praxis investigativa. Esto en concordancia con los Campos Institucionales de Investigación de la Universidad de La Salle y las líneas y grupo de investigación en Pensamiento Archivístico; de esta manera la MGDAA contribuye a la generación y transferencia de conocimiento al desarrollar la línea de investigación Información, conocimiento y sociedad.

\section{Contexto actual}

A partir de las tendencias emergentes a nivel mundial en relación con la gestión de la información, el valor agregado de la Maestría radica en combinar dos áreas de formación, por un lado la gestión documental, cuyo auge en las organizaciones modernas la ubican en el centro de la gestión del conocimiento corporativo, y por el otro la administración de la memoria institucional depositada y conservada en los archivos, desde los cuales se apoya la toma de decisiones y los procesos de investigación, así como la protección de los derechos ciudadanos. Desde esta perspectiva se conciben nuevas dimensiones en términos de la función social de la información y los archivos, como instrumentos de desarrollo, democratización del conocimiento y participación ciudadana. Adicionalmente, al ser éste el primer programa de Maestría semipresencial abre posibilidades de internacionalización de la formación de maestrantes en Archivística provenientes de otros países del continente y por supuesto impacta las regiones; es así como el $72 \%$ de los estudiantes actuales provienen de diferentes partes del país y se tiene el primer estudiante internacional, esto dada la organización académica, ya que el período de docencia presencial se lleva a cabo mediante la asistencia obligatoria de los maestrantes en Bogotá, durante dos semanas intensivas (12 días), para un total de 96 horas; el período académico 
no presencial se desarrolla mediante estrategias virtuales a través de medios de comunicación e información telemáticos y el uso de la plataforma virtual de la Universidad.

Esta modalidad ha permitido que la docencia presencial haya sido impartida por docentes de países como España y Portugal, con lo cual se han desarrollado convenios con Universidades como Salamanca, Oporto y Extremadura tratando de buscar el perfil más alto de formación y experiencia, dado que por el momento el país no cuenta con doctores en el área. De esta manera el profesor titular es apoyado por los docentes-tutores del programa cuyo requisito mínimo es contar con Maestría y una amplia experiencia laboral y académica en archivística.

La selección de los estudiantes ha sido cuidadosa teniendo en cuenta o bien formación previa en el área o una demostrada experiencia laboral; asimismo esto se evalúa en la entrevista de selección donde además el estudiante presenta un ensayo en el que evidencia su interés de investigación.

Hoy el programa cuenta con estudiantes provenientes en su mayoría de las regiones del país (Cundinamarca, Bolívar, Cauca, Magdalena, Boyacá, Santander, Arauca, Valle, Guajira, Magdalena, Cesar y Casanare) y abarca una cobertura de 12 de los 32 departamentos que tiene el país, y un estudiante del exterior procedente de México.

Se ha logrado un perfil diverso que cuenta con profesionales de diferentes áreas del conocimiento: Sistemas de Información, Bibliotecología y Archivística, Ingenierías, Contaduría, Administración, Historia, Derecho y Economía, lo que le da un énfasis interdisciplinar al programa.

Es interesante resaltar que la mayor parte de los estudiantes son mujeres, representadas con un $68 \%$ mientras que se cuenta con el $32 \%$ de hombres.

Mirando hacia el futuro

El avance de las tecnologías de la información nos permitirá contar cada vez con herramientas más eficientes para la educa- 
ción virtual, lo que desde luego redundará en una formación de mayor calidad.

Es necesario desarrollar esquemas de autoformación más especializados en herramientas virtuales ya que se han detectado dificultades por parte de los maestrantes, especialmente en las personas más adultas.

- Aunque actualmente la maestría tiene un carácter profesionalizante su desarrollo debe reflejarse en una Maestría Investigativa que redunde a largo plazo en un Doctorado.

La cobertura debe ampliarse de manera que se logre llegar a todas las regiones del país, ya que como se ha identificado sólo en las grandes ciudades se cuenta con personal lo suficientemente bien formado.

Dada la ausencia de maestrías de esta índole, la oportunidad de internacionalización debe verse reflejada en estrategias más agresivas de comunicación para que se logre así impactar a toda la comunidad archivística latinoamericana.

El programa pretende consolidarse como alternativa de formación y perfeccionamiento de profesionales para otras regiones de nuestro país y de otros países del América Latina y el Caribe. El Programa de Sistemas de Información y Documentación sigue interesado en presentar nuevas propuestas, por ello en el corto plazo y dado el desarrollo de los diferentes soportes documentales se planteó la necesidad de estructurar una nueva especialización en información digital que prepare a bibliotecólogos y archivistas para afrontar los retos que implica la organización, recuperación, almacenamiento y conservación de este tipo de información. A mediano plazo se ofertará con la misma estructura la Maestría en Bibliotecología y esperamos a futuro y de acuerdo con nuestro avance investigativo ofrecer nuestro primer doctorado. 


\section{REFERENCIAS BIBLIOGRÁFICAS}

Programa de Maestría en Gestión Documental y Administración de Archivos, Registro Calificado de Programas 2010, Bogotá, Universidad de La Salle, 2008, 115 p.

Rendón, M. (2008), "Ciencia bibliotecológica y de la información en el contexto de las ciencias sociales y humanas. Epistemología, metodología e interdisciplina”, en Investigación Bibliotecológica, 22, 44, enero-abril, pp. 65-78.

Universidad de La Salle (2008), Lineamientos para la redimensión permanente de la malla curricular, Bogotá, Ediciones Unisalle, p. 37.

Vallejo Sierra, Ruth Helena y Carlos Alberto Zapata Cárdenas, Redimensionando la formación de archivistas: una aproximación a la formación archivística desde la Universidad de La Salle, Bogotá, Colombia (mimeo). 
Oportunidades y retos en la formación, investigación y aplicación...

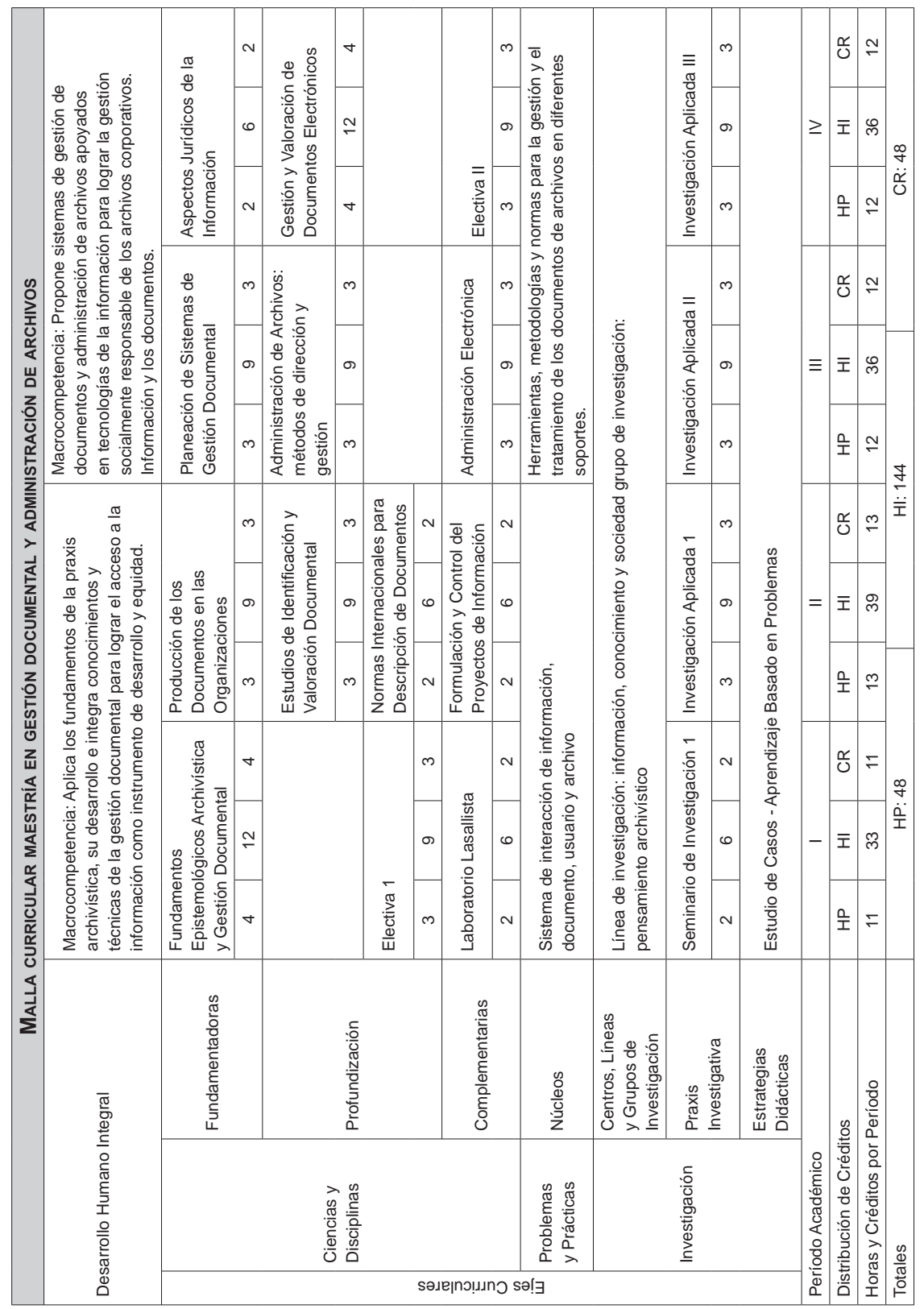




\title{
La investigación bibliotecológica sobre comunidades indígenas
}

\author{
César Augusto Ramírez VelázQuez \\ Instituto de Investigaciones Bibliotecológicas \\ $y$ de la Información, UNAM
}

\section{ANTECEDENTES}

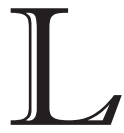

a investigación bibliotecológica sobre comunidades indígenas es un tema que se ha venido trabajando de manera intermitente desde 1992, en el período en que la Dra. Elsa Margarita Ramírez Leyva fue directora del Centro Universitario de Investigaciones Bibliotecológicas (CUIB) de la UNAM, por algunos investigadores como María del Rocío Graniel Parra, Martha Añorve Guillen, Ariel Alejandro Rodríguez García y Filiberto Felipe Martínez Arellano, quienes han desarrollado trabajos y proyectos relacionados con problemas derivados de la carencia de colecciones, servicios bibliotecarios y de información, infraestructura bibliotecaria, estudios de usuarios y formación de personal idóneo que atienda las bibliotecas para este tipo de comunidades, y otros.

La mayor parte de los trabajos tenía la finalidad de conocer y explicar las características, necesidades y comportamientos de las personas que conforman las comunidades indígenas, en relación al uso de la información y los servicios bibliotecarios, la adecuación de la infraestructura de las bibliotecas y, especialmente, la preparación de individuos (de la propia comunidad principalmente) en las actividades básicas con las que pueden organizar colecciones y dar servicios adecuados a los integrantes de sus comunidades.

Por otra parte, en los comienzos del siglo xxI, los investigadores del сиів han realizado e intervenido a la par en reuniones colegia- 
Oportunidades y retos en la formación, investigación y aplicación...

das relacionadas con el tema, con investigadores, académicos y especialistas tanto del país como del extranjero, en eventos entre los que podemos mencionar el 1er. Encuentro latinoamericano sobre la atención bibliotecaria a las comunidades indígenas, realizado en México, el $2^{\circ}$ realizado en Lima, Perú y el $3^{\circ}$ en Brasil.

En cuanto a otros documentos publicados en lo que va de este siglo están los siguientes:

* María del Rocío Graniel Parra, con Las comunidades indígenas y los servicios bibliotecarios en México: un estudio de caso; Programa de formación en servicios bibliotecarios y de información para la atención a las comunidades indígenas rurales mexicanas. Año 2002.

Ariel Alejandro Rodríguez García, con la Propuesta de un programa para la formación de bibliotecólogos rurales e indígenas. Filiberto Felipe Martínez Arellano, con la Formación de Recursos Humanos para el Desarrollo de Servicios Bibliotecarios en Comunidades Indigenas: una propuesta; Servicios Bibliotecarios para comunidades indigenas en América Latina; Modelo de formación para bibliotecarios de comunidades indígenas; Programa de formación de recursos humanos para la atención de servicios bibliotecarios en comunidades indígenas.

César Augusto Ramírez Velásquez, con: Desarrollo de colecciones para comunidades indigenas; Necesidades de Información en comunidades indigenas: el caso de la comunidad tepebua; El papel social de la mujer indigena visto a través de sus necesidades de información: el caso de la mujer tepebua; La satisfacción de las necesidades de información como factor de cambio de la identidad indígena en la comunidad amuzga: reporte de avances y nuevos avances; La identidad en la Declaración de los Derechos Indigenas de la ONU y su implicación en los servicios bibliotecarios; La investigación de las necesidades de información en las comunidades indígenas: campo propicio para impulsar su desarrollo social; ¿Por qué investigar las necesidades de información de las comunidades indígenas? y Las necesidades de información como elemento de análisis de las colecciones de bibliotecas de comunidades indigenas. 
Gabriela Olguín Martínez, con el trabajo Apoyo bibliográfico que ofrecen las bibliotecas de la UNAM a sus estudiantes indigenas.

* Florybeth Sánchez Espinoza, con Gestión de la información en pueblos indígenas: una contextualización desde la experiencia.

Asimismo encontramos que a partir del 2000 también se han generado en la licenciatura y el posgrado los siguientes trabajos de investigación:

* Georgina Yuriko Valdez Ángeles, con el Tesauro sobre pueblos indigenas de México y América Latina.

* Hortensia Mireles Cedillo, con Propuesta de preservación y conservación de los documentos de la comunidad Ajusco.

* Edith Bautista Flores, con El perfil de los usuarios de información: los alumnos de la comunidad de Yabuitlalpan y de Zautla en el estado de Puebla.

Delmi Marcela Pinto López, con Necesidades y comportamiento informativo de los universitarios indigenas.

* Fabián Hernández Pedraza, con Necesidades de información de la comunidad de San Matías Tlalancaleca, Puebla.

\section{ÁrEAS DE OPORTUNIDAD DE LA INVESTIGACIÓN SOBRE COMUNI- DADES INDÍGENAS}

En esta época, y en el marco de las sociedades de la información, el espectro de la investigación en este tenor ha cambiado al ofrecer una serie de áreas de oportunidad y retos que la disciplina bibliotecológica no puede soslayar, particularmente en relación con las comunidades indígenas.

Es un hecho inobjetable que los cambios sociales y económicos, así como el desarrollo tecnológico han generado amplias modificaciones en cuanto a la información y los servicios adecuados para su compilación, organización, conservación, difusión, promoción, comunicación e integración para los diversos grupos sociales, sobre todo los tan específicamente vulnerables como las comunidades indígenas. 
Es por ello de suma importancia desarrollar proyectos que aborden la problemática del desarrollo de servicios bibliotecarios que integren, organicen y controlen la información. Se mencionan a continuación los tópicos de investigación bibliotecológica y de la información que podrían enfocar las comunidades indígenas:

- Se piensa aquí en el valor social de la biblioteca indígena como una entidad activa que pueda disponer y brindar información relacionada con temas tales como:

- Los derechos humanos y los derechos indígenas.

- El derecho a la información y a la lectura.

- La participación ciudadana.

- Las organizaciones sociales y políticas.

- Las estructuras gubernamentales.

- Las políticas sociales y públicas.

- El multiculturalismo.

- La interculturalidad.

- La aculturalidad.

- La migración.

El impacto del acceso a la información no debería tener políticas restrictivas en lo que se refiere a:

- el género,

- el empleo,

- el establecimiento de negocios, empresas y cooperativas,

- la pobreza extrema,

- el derecho a la educación,

- las becas educativas y los programas de movilidad,

- la integración de centros escolares de educación secundaria, media superior, técnica y superior en las zonas indígenas más pobladas,

- las bibliotecas escolares, académicas y públicas en todas las localidades indígenas,

- el establecimiento de perfiles de usuarios definidos para el desarrollo de colecciones ad-hoc, y

- las políticas públicas de información dirigidas a la atención bibliotecaria de este tipo de usuarios.

Es preciso evitar o ayudar a evitar la pérdida de valores y la 
transformación de la identidad en estas comunidades.

Hay que conservar la información oral y escrita de las lenguas nativas, de la cultura en toda la acepción de la palabra, en cada comunidad.

Sería vital digitalizar el conocimiento que es transmitido de forma oral, y no sólo aquél que ya se encuentra plasmado en impresos, videos, formatos sonoros o películas; sino también como comenta el Dr. Voutssas, “...el conocimiento que se digitaliza directamente,... abriendo la posibilidad de la incorporación de bibliotecas digitales para este tipo de comunidades".

Las comunidades indígenas están también inmersas de muchos modos en:

- las sociedades del conocimiento,

- las nuevas tecnologías,

- los resultados de la brecha digital,

- las redes sociales,

- la Web 2.0,

- los blogs,

- los sistemas de información,

- los medios masivos de comunicación (radio, televisión, telefonía, Internet, etcétera),

- la globalización de la economía y del conocimiento,

- la información escrita y las otras diversas culturas.

En específico otros tópicos que afectan e influyen en estos grupos son:

- los deportes practicados,

- las grandes catástrofes,

- la polución,

- la ecología,

- las nuevas enfermedades,

- la inseguridad,

- las opciones de trabajo,

- y la integración de estas comunidades a los posibles procesos de rescate de su cultura en conjunto con la biblioteca y otros organismos interesados. 
Oportunidades y retos en la formación, investigación y aplicación...

\section{Consideraciones finAles}

Mencionadas las áreas problemáticas y de oportunidad, es necesario, de ser posible, establecer y organizar de manera sistematizada en toda la gama de tópicos mencionados y otros más, una agenda de investigación lo suficientemente amplia, para que el cuib, como institución académica de investigación, asuma y consolide su liderazgo madurando un programa ad-boc que involucre a diversas instancias académicas, así como a diversos actores tales como investigadores, académicos y alumnos tanto de licenciatura como de posgrado, nacionales y extranjeros para formar una red o redes que desarrollen proyectos de investigación, así como seminarios y foros de discusión que produzcan y aporten alternativas de solución a los urgentes problemas derivados de las temáticas mencionadas, y elaborar e implantar soluciones con todas aquellas instancias pertinentes, políticas públicas y sociales que favorezcan el desarrollo de las comunidades indígenas que tanta ayuda necesitan.

Dichos proyectos deben ser de gran aliento, multidisciplinarios, interdisciplinarios y transdiciplinarios, y tener el objetivo de lograr conformar propuestas de cambio y soluciones en el ámbito continental, cuyo objetivo prioritario, aunque suene reiterativo, sea el de apoyar el esfuerzo de las diversas comunidades indígenas por superar sus condiciones sociales, económicas y culturales y enfrentar con una mejor actitud y mejores perspectivas los tiempos venideros.

\section{Bibliografía}

Acceso a los servicios bibliotecarios y de información en los pueblos indigenas de América Latina: memorias del Seminario en Lima, Perú, 23 al 25 de abril de 2003 (2003), Lima, Perú, Ifla/Alp, (Project Report núm. 22).

Encuentro latinoamericano sobre la atención bibliotecaria a las comunidades indigenas: memoria del encuentro 15-17 de noviembre de 2000 en la ciudad de México (2001), México, unAM, CUIB; IFLA. 
Graniel Parra, M. R. (2002), Las comunidades indigenas y los servicios bibliotecarios en México: un estudio de caso, México, Tesis de Maestría (Maestría en Bibliotecología) unAm, Facultad de Filosofía y Letras.

La investigación y la educación bibliotecológica en la sociedad del conocimiento (2010), Memoria del XXVII Coloquio de Investigación Bibliotecológica y sobre la Información, 28-30 de septiembre de 2009, México, unAm, CuIB.

Ramírez Velázquez, C. A. (2009), Necesidades de Información en Comunidades Indigenas: el caso de la comunidad tepebua, México, UNAM, CUIB.

Rodríguez García, A. A. (2003), Propuesta de un programa para la formación de bibliotecólogos rurales e indigenas, México, Tesis de Maestría (Maestría en Bibliotecología) unam, Facultad de Filosofía y Letras. 



\section{Metodología para la enseñanza y el aprendizaje en materia de estudios de usuarios de información}

IsABEL VILLASEÑOR RODRÍGUEZ

Universidad Complutense de Madrid, España

\section{INTRODUCCIÓN}

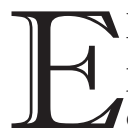

1 objetivo principal de nuestra comunicación es el de hacer partícipes a los asistentes de algunas reflexiones y experiencias personales relacionadas con la docencia en materia de estudios de usuarios de información.

Ante todo queremos dejar claro qué entendemos por "estudios de usuarios de información" para saber de dónde partimos. No se trata de profundizar en tal asunto ya que nos encontramos ante una materia sobre la que queda mucho por decir. Hasta el momento no existe uniformidad en las comunidades académica y profesional de nuestros países respecto al concepto y las aplicaciones así como en cuanto a la terminología a emplear en dicho ámbito. Por eso preferimos exponer nuestra visión personal del asunto y nos inclinamos por afirmar que por "estudios de usuarios de información" se entiende el conjunto de investigaciones encaminadas a conocer todo lo concerniente al usuario de información. Se trataría de una actividad que, mediante la aplicación de uno o varios métodos, busca el conocimiento (la identificación y la caracterización) de todo lo relativo a las necesidades informativas del ser humano. Esto vendría a identificarse con lo que Juan José Calva ha dado en llamar "el fenómeno de las necesidades de información" que afecta no sólo al surgimiento de la necesidad de información en cual- 
quier individuo sino también a su comportamiento en la búsqueda de la información que necesita y a su satisfacción o insatisfacción respecto de ella. Este fenómeno consideraría también el conocimiento de las distintas aplicaciones de dichas investigaciones así como los distintos métodos, técnicas y herramientas a emplear para recabar información sobre el objeto de estudio. A partir de ahí, podrían conocerse las necesidades y comportamientos de una posible tipología de usuarios de información.

El interés de la enseñanza y el aprendizaje en esta materia viene dado por las múltiples aplicaciones que el desarrollo de este tipo de investigaciones puede aportar al progreso de profesiones relacionadas con la Bibliotecología y la Documentación.

Como hemos dicho en otras ocasiones hoy en día no existe duda, en nuestro ámbito, sobre la importancia que tiene el usuario de la información y su estudio y conocimiento. Él es la razón de ser del ámbito práctico de nuestras disciplinas (los centros de información y sus profesionales) y también del teórico (los centros de investigación y formación y sus profesionales). Se trata de un asunto de vital importancia para nuestras materias de estudio y para la práctica profesional relacionada con ellas. Así ocurre con los estudios de usuarios de información, y son muchas las voces que se han levantado en defensa de su práctica al considerar la utilidad que ofrecen.

Sin embargo tal como vimos a través de un estudio presentado en el VII Seminario hispano-mexicano de investigación en Bibliotecología y Documentación (celebrado en el сuів del 7 al 9 de abril de 2010), el interés por los estudios de usuarios de información y su evolución metodológica y conceptual no se corresponden en España, tanto como quisiéramos, con su presencia en los planes de estudio universitarios conducentes a la obtención de alguna titulación en Biblioteconomía y Documentación (Diplomatura, Licenciatura, Grado o Máster). En ese estudio, titulado La formación universitaria española en materia de estudios de usuarios de información, se identificaron aquellos centros públicos de formación universitaria en Biblioteconomía y Documentación en los que se imparten asignaturas relacionadas con el asunto y se analizaron sus características básicas, esto es, su denominación, duración, carácter, contenidos, ti- 
tulación y curso en el que se imparten. La principal conclusión a la que se pudo llegar entonces es que la libertad de acción por parte de los centros educativos respecto a la incorporación de asignaturas a sus planes de estudio, así como a la determinación del carácter y la duración de las mismas, hace que la formación universitaria española en materia de estudios de usuarios de información ofrezca una gran variedad respecto a la denominación, titulación y cursos en los que se imparten, y un número de créditos/horas asignados, carácter e, incluso, contenidos. Y en relación con esto último, los contenidos, así como la metodología a emplear, se encuentra nuestra comunicación, una propuesta que intentará responder a las preguntas de ¿por qué o para qué?, ¿qué? y ¿cómo? enseñar y aprender en materia de estudios de usuarios de información.

Lo que queremos es ofrecer una propuesta docente basada en la experiencia personal de una asignatura que venimos impartiendo desde 1996 y que lleva por nombre "Estudios y formación de usuarios". Nos centraremos en la primera parte de dicha asignatura, que es la que tiene que ver con el tema que nos ocupa. De esta manera vamos a hablar de los objetivos, de los contenidos y de la metodología a seguir y su desarrollo, para terminar mostrando los datos de un estudio evaluativo que se llevó a cabo con los alumnos y que nos puede servir de conclusión.

Los OBJETIVOS. ¿POR QUÉ O PARA QUÉ?

El objetivo fundamental y explícito (se da a conocer en la guía académica) que se persigue con el desarrollo de esta asignatura es iniciar al alumno en la importancia de estos temas, poniéndolo en conocimiento de la significación de los conceptos básicos, así como de las distintas tipologías que existen sobre los usuarios y los posibles métodos que pueden emplearse en su análisis. Pero, al mismo tiempo se pretenden desarrollar en él competencias profesionales y de carácter básico que le sean útiles para su futuro desempeño profesional. De esta manera consideramos como objetivos implícitos algunos de los relacionados con determinadas competencias 
profesionales marcadas por el Euroreferencial en Información y Documentación, que define a éstas como "el conjunto de las capacidades necesarias para ejercer una actividad profesional y dominar los comportamientos requeridos". ${ }^{1}$ Incluimos a continuación las capacidades que se han tenido en cuenta a la hora de determinar otros objetivos:

* Grupo I (Información): relaciones con los usuarios y los clientes: comprensión del medio profesional.

Grupo C (Comunicación): comunicación oral; comunicación escrita; comunicación interpersonal.

* Grupo G (Gestión): mercadotecnia; gestión de proyectos y planificación; diagnóstico y evaluación, y formación y acciones pedagógicas.

El mismo Euroreferencial nos proporciona un listado de aptitudes observables a partir de comportamientos que son de interés para ejercer la profesión y que sirven para completar los objetivos expuestos hasta el momento. Entre las aptitudes que se podrían fomentar, a través de las prácticas desarrolladas en la asignatura, están las siguientes:

Relaciones: autonomía, (capacidad de) comunicación, disponibilidad, empatía, (espíritu de) equipo, (sentido) pedagógico.

Búsqueda: curiosidad intelectual.

Análisis: (espíritu de) análisis y síntesis, (espíritu) crítico.

Comunicación: (capacidad de) respuesta rápida.

Gestión: perseverancia, rigor.

Organización: (capacidad de) adaptación, (sentido de) anticipación, (espíritu de) decisión, (espíritu de) iniciativa, (sentido de la) organización.

1 ECIA. Euroreferencial en Información y Documentación. Volumen 1. Competencias y aptitudes de los profesionales europeos de información y documentación, segunda edición completamente revisada, Madrid, SEDIC, 2004. 


\section{LOS CONTENIDOS. ¿QUÉ?}

Los contenidos de la asignatura se estructuran en distintos apartados:

1. Consideraciones generales.

2. Definición de conceptos básicos.

3. Historia de los estudios de usuarios.

4. Aplicaciones de los estudios de usuarios.

5. Metodología de recogida de datos (Métodos, técnicas y herramientas).

6. Cómo hacer un estudio de usuarios.

7. Análisis de los distintos tipos de usuarios y necesidades informativas.

En el primer apartado, Consideraciones generales, se presenta la asignatura en sus aspectos formales y de desarrollo:

* contexto académico,

* razón de ser como práctica profesional, como contenido docente/académico y como línea de investigación desarrollada no sólo por docentes universitarios sino también por profesionales, objetivos perseguidos, contenidos a desarrollar, metodología docente a emplear y evaluación.

Además se ofrece una bibliografía básica para que el alumno pueda guiarse con ella y se presentan los acuerdos (la importancia del usuario y de su satisfacción, así como la necesidad de conocerlo) y desacuerdos (respecto a la base teórica/conceptual, la terminología y el objeto de estudio) de autores que han escrito sobre este asunto.

En el segundo apartado, Definición de conceptos básicos, se afronta la tarea de definir lo que consideramos como "conceptos implicados" y que son:

Usuario

Necesidad y tipos 
Oportunidades y retos en la formación, investigación y aplicación...

\section{Deseo}

Demanda

Conducta, hábito, comportamiento, búsqueda

Uso. Satisfacción/insatisfacción

Contexto/entorno (factores externos e internos)

Tras el análisis de estos elementos se ofrecen distintas definiciones de lo que se entiende por "estudio/estudios de usuarios".

El tercer módulo, Historia de los estudios de usuarios, se aplica a mostrar los antecedentes así como la evolución de esta disciplina y su práctica, haciendo hincapié en su desarrollo en España.

En este punto del desarrollo de la asignatura, una vez que se han definido los conceptos básicos y se ha conocido la evolución de la práctica académica y profesional de los estudios de usuarios de información, toma sentido incluir el cuarto apartado: Aplicaciones de los estudios de usuarios, donde se habla del uso que se ha hecho y hace en la actualidad de estos estudios. Algunas de esas aplicaciones son:

Planificar los sistemas de información.

Conocer las necesidades de información de los usuarios (presentes y previsibles, reales y potenciales) y sus cambios, y conocer el grado de satisfacción de usuarios de un centro o de usuarios de información en general (colectivos).

Conocer las motivaciones, actitudes, valores o deseos de los usuarios respecto al centro y a la información en general.

* Evaluar el centro y, consecuentemente, evaluar el sistema local, regional y nacional de información.

Evaluar los recursos de información.

Detectar problemas para adecuar los servicios, los espacios, el fondo, las normas, las tareas y el personal de los centros de información.

Medir la eficacia de los centros de información.

- Justificar la existencia del centro o de un servicio y apoyar demandas presupuestarias.

Conocer la estructura y dinámica de los colectivos de investigadores. 
Facilitar la realización de cursos de formación de usuarios.

A continuación, en el quinto módulo, pasamos a la explicación pormenorizada y damos ejemplos de lo que hemos dado en llamar la Metodología de recolección de datos. En este apartado se exponen:

* los métodos

- directo e indirecto,

- cualitativo y cuantitativo;

- las técnicas

- la encuesta por correo, por teléfono o de entrega en el centro,

- el Método Delphi,

- la entrevista personal,

- el focus group,

- el incidente crítico,

- la consulta de estudios anteriores y de publicaciones sociológicas,

- el recuento y análisis de citas y de referencias,

- el recuento y análisis de las transacciones entre el usuario y el sistema,

- la observación,

- el cliente oculto/simulado,

- la gestión de sugerencias y desideratas;

las herramientas o instrumentos

- el cuestionario,

- el guión de entrevista,

- el censo,

- el registro,

- el entrevistador,

- la grabación,

- etcétera,

empleados en la recolección de datos necesarios para llevar a cabo un estudio de usuarios de información.

El sexto apartado, Cómo hacer un estudio de usuarios, ofrece una breve guía del proceso que integra el conjunto de medios y 
tareas que permiten lograr un fin muy específico, y que es el de realizar un estudio de usuarios de información. ${ }^{2}$ Aunque no existen normas sobre el asunto conviene hacer ver al alumno que es necesario tener un plan de trabajo que responda a ideas prefijadas. Proponemos uno basado en tres etapas: planificación, ejecución y presentación. En la primera de ellas desarrollamos los siguientes asuntos:

Identificar y definir el problema de investigación.

- Justificar el tema en relación con el interés o utilidad que represente.

Analizar el estado de la cuestión.

* Hacer el diseño metodológico de la investigación:

- método/s, técnica/s, instrumento/s,

- enfoque aplicable,

- diseño del instrumento,

- población,

- muestra.

Considerar los aspectos temporales (plazos), burocráticos (permisos) o materiales necesarios así como de personal (número, preparación).

Valorar el modo de promoción a emplear para que los usuarios participen en el estudio (si es que se necesita su participación). Sopesar la práctica de un estudio piloto.

En la segunda etapa, la de ejecución, se consideran los temas siguientes:

* Recopilar la información, analizar los datos obtenidos y redactar las conclusiones.

2 Sobre este tema puede encontrarse información más detallada en Isabel Villaseñor Rodríguez (2010), "Los estudios de usuarios de información como línea de investigación prioritaria en Bibliotecología y Documentación", en Memoria del XXVII Coloquio de Investigación Bibliotecológica y sobre la Información: la investigación y la educación bibliotecológica en la sociedad del conocimiento, México, Universidad Nacional Autónoma de México, Centro Universitario de Investigaciones Bibliotecológicas, pp. 161-175. 
La tercera y última etapa, la presentación, contempla temas relacionados fundamentalmente con el informe final; esto es, con el contenido y la forma del documento que debe presentar el proceso seguido y los datos obtenidos en un estudio de usuarios de información.

Dejamos para el final el apartado que lleva por título Análisis de los distintos tipos de usuarios y necesidades informativas. Aunque no existe una tipología uniforme, le mostramos al alumno algunos de los criterios que deben tener en cuenta a la hora de determinar una posible tipología de usuarios y de sus necesidades informativas. A continuación presentamos un esquema de la tipología con la que trabajamos.

1. Por el uso que hacen del centro:

usuarios

- potenciales,

- reales,

- presenciales,

- no presenciales,

- no usuarios.

2. Por el tipo de información que requieren:

* usuarios de información general y

* usuarios de información especializada.

3. Por la edad:

usuarios infantiles

- prelectores,

- lectores,

usuarios juveniles,

usuarios adultos (especial atención a la Tercera Edad).

4. Por el tipo de centro de información:

usuarios de bibliotecas

- por el acceso: bibliotecas públicas, privadas,

- por el grado de especialización de sus fondos y sus servicios: generales, especializadas,

- por la finalidad: apoyo a centros docentes, apoyo a entidades superiores,

usuarios de archivos 
- internos,

- externos,

- investigadores,

- ciudadanos sin formación científica,

- estudiantes (distintos niveles e intereses),

usuarios de centros de documentación

- por el acceso: centros públicos, privados,

- por la relación con el centro: internos y externos,

usuarios de centros informatizados

- presencial,

- iniciados y autosuficientes,

- que saben poco o nada,

- virtual.

5. Por competencia, habilidades y conocimientos para manejarse con la documentación-destreza (en relación con el grado de alfabetización en información o educación documental): mayor o menor grado, menor o mayor dependencia del profesional de la información.

6. Por el tipo de fuentes de información que usan:

según la procedencia: fuentes personales, documentales, institucionales,

* según el soporte: papel, audiovisual, electrónico.

7. Por el tiempo y material requeridos para satisfacer las demandas así como por el grado de satisfacción en relación con la respuesta recibida.

8. Otros condicionantes que determinan la capacidad para acceder a la información:

* económico-sociales: grupos de población más desfavorecidos, culturales: lengua,

ocupación: trabajadores (fuera y dentro de casa), en paro, estudiantes, jubilados,

* nivel de formación: sin estudios, con estudios (primarios, secundarios, superiores),

físicos (alguna discapacidad), geográficos (cercanía o lejanía del centro).

9. Clasificación de Elías Sanz, (según las pautas de comportamiento que siguen): 
* el investigador y el docente,

* el usuario de la industria/empresa,

* el administrador, planificador y político y

* el hombre de la calle.

\section{LA METOdología. ¿Cómo?}

Lo más destacable de la metodología empleada desde el comienzo en la asignatura de la que hablamos es el hecho de que se adecua al cambio de paradigma invocado por los principios del Espacio Europeo de Educación Superior, que fomenta nuevos modelos de formación centrados en el trabajo del estudiante para su aprendizaje. El uso de nuevas y variadas estrategias didácticas aplicadas fuera y dentro del aula y otros espacios; la transformación de la figura del docente en el sentido de que su papel no es únicamente el de transferir conocimientos sino el de elaborar y coordinar las actividades y materiales necesarios para alcanzar las competencias que desea fomentar; la utilización de la evaluación continuada; la planificación de tareas que desarrollen el aprendizaje autónomo... Por todo ello, la asignatura que nos ocupa desarrolla un modelo de instrucción mixto que combina lo que Svinicki y Schwartz ${ }^{3}$ llaman instrucción indirecta (el alumno descubre la información por sí mismo, controlando así su propio aprendizaje con simulaciones de situaciones reales, por ejemplo), e instrucción semidirecta (controlada por el docente pero con una participación muy activa del alumno; esto es, las clases prácticas). Se trata de colocar al alumno en situaciones prácticas lo más cercanas a la realidad profesional; situarlo frente a problemas que deba resolver por sí mismo aunque con la orientación del docente. La mayor parte de las veces lo anterior se hace incluso antes de desarrollar los contenidos teóricos correspondientes, de forma que la actividad práctica

3 Marila Svinicki y Barbara A. Schwartz (1991), Formación de profesionales y usuarios de bibliotecas: aprendizaje y diseño de instrucción, Madrid, Salamanca, Fundación Germán Sánchez Ruipérez. 
sirva de herramienta de aprendizaje, y la teórica para afianzar los contenidos aprendidos en la práctica. Se trata, a grandes rasgos, de aplicar el binomio enseñanza-aprendizaje tanto dentro como fuera del aula, distribuyendo el tiempo dedicado a lecciones magistrales y prácticas de los alumnos, y proporcionándole mayor protagonismo al aprendizaje del alumno a partir de su trabajo independiente. De esta manera, de las 4 horas dedicadas semanalmente a la asignatura (en dos días) y en el aula, tan sólo una se dedica a la lección magistral, mientras que el resto se consagra a los alumnos (trabajos en grupo, exposición y debate, resolución de dudas). Estas actividades se complementan con tareas de enseñanza-aprendizaje fuera del aula (tutorías, visitas a instituciones y trabajos de campo individuales) con una dedicación estimada en 26 horas.

Teniendo en cuenta lo dicho la estructura de la clase se basa en la exposición de contenidos utilizando la lección magistral a partir de una conferencia del docente o de algún invitado (los bibliotecarios del centro, por ejemplo), del visionado de proyecciones (de esquemas, videos o páginas web) o de un guión repartido entre los alumnos en fotocopias. Esta actividad requiere de unos $30 \mathrm{minu}-$ tos de duración. A continuación se distribuyen los alumnos en los grupos de trabajo establecidos desde el primer día de clase, y desarrollan la actividad correspondiente. Al desarrollo de la actividad, la puesta en común por grupos, la exposición para la puesta en común de todos los miembros de la clase y el análisis de la relación entre la teoría y la práctica así como de los métodos empleados por cada grupo para el trabajo en común, se dedican en torno a 75 minutos, y los 15 restantes a aclarar dudas que hayan podido surgir. Para esta tarea se dedican no sólo estos minutos (30 en la semana y en el aula) sino 6 horas en el despacho de la docente y un tiempo sin determinar aún a través del correo electrónico.

Algunas de las actividades que se realizan son:

* Análisis de un cuestionario sobre hábitos de lectura y uso de bibliotecas: los alumnos trabajan con él individualmente al tenerlo que rellenar, repartir entre cuatro usuarios de su entorno y evaluar; la actividad en grupo consiste en el recuento de los 
datos obtenidos individualmente y en la puesta en común de las valoraciones individuales.

Asistencia a la conferencia impartida por un bibliotecario del centro sobre los tipos de usuarios que acuden a él: los alumnos trabajan con las notas tomadas individualmente y en grupo, poniendo en común los distintos resúmenes y creando una tipología de usuarios con sus correspondientes criterios que, al acabar la actividad y tras un debate, forma parte de una macro-tipología que viene elaborándose desde hace seis cursos académicos.

Lectura de textos (en publicaciones electrónicas e individualmente fuera del aula, y en papel, en grupos y en el aula) que exponen distintos estudios de usuarios de información: los alumnos analizan los textos para extraer datos tales como quiénes hacen estudios de usuarios en España, para qué, con qué métodos de recolección de datos, cómo exponen los datos, etcétera.

Diario: los alumnos elaboran un diario desde el comienzo del curso donde dan cuenta de los contenidos expuestos por la docente, las actividades prácticas realizadas y cualquier otro asunto relacionado con la asignatura. Algunos de ellos, además de describir, valoran el método docente o hacen propuestas. Los diarios deben entregarse cada cuatro sesiones y al final del curso.

La evaluación de la asignatura se lleva a cabo a partir de la valoración de cada una de las actividades efectuadas fuera y dentro del aula (se toma nota en las fichas de los alumnos) y de un trabajo de campo que se basa o bien en la elección de un centro de información (archivo, biblioteca o centro de documentación) o bien en una sección (préstamo, sala de consulta, sección infantil, etc.) o en un grupo de usuarios; así como en el estudio del tipo de usuarios y necesidades. Para ello el alumno deberá ponerse en contacto con los responsables del centro. Se trata de un recurso que permite que el alumno se encuentre inmerso en la realidad profesional al entrar en contacto directo con los centros y sus responsables y usuarios. De este trabajo se valora el contenido, la expresión (exposición, redacción) y la presentación externa. Para el planteamiento y observación de su desarrollo se utilizan las clases prácticas y las tutorías. 


\section{A modo De CONClusión: LA OPINIÓN DE los ALUMNOS}

Con el fin de conocer la opinión que les merece a los alumnos el desarrollo de la asignatura, durante el curso 2007-2008 se elaboró un cuestionario compuesto de 18 preguntas referidas a metodología, contenidos y experiencia personal y que respondió el 65\% de la población total. De los resultados obtenidos queremos destacar algunas cuestiones, como las siguientes:

* la asignatura ha respondido a sus expectativas,

* los contenidos han resultado serles nuevos y estar acordes con la demanda actual de los empleadores, al igual que han servido para tener una visión distinta de los centros de información y de sus usuarios,

prefieren los métodos docentes indirecto (simulación de situaciones reales) y semidirecto (lección teórica y prácticas),

* el sistema de evaluación utilizado es el apropiado,

* han dedicado a la asignatura y fuera del aula una media de entre 30 y 50 horas para hacer fundamentalmente trabajos prácticos o buscar información en Internet,

las prácticas realizadas dentro y fuera del aula les han servido para aplicar los conocimientos teóricos y conocer la realidad de la profesión,

* la redacción del diario no les ha supuesto ningún esfuerzo y, en el caso de haber sido así, la razón ha sido la de la falta de tiempo, * la mayoría ha intervenido alguna vez en clase para dar su opinión sobre el tema que se trataba o aclarar dudas, y para externar que la asignatura les ha gustado y la recomendarán.

Nuestra opinión sobre el desarrollo de la asignatura es en general positiva. Quizá destacaríamos como elementos negativos la poca experiencia del alumno ante el uso de las nuevas tecnologías en la presentación de sus prácticas o de métodos docentes distintos de la lección magistral. Aunque hay que decir que en el desarrollo del cuatrimestre, siempre se observa una evolución, hacia mejor, en este sentido. 


\section{REFERENCIAS BIBLIOGRÁFICAS}

ECIA. Euroreferencial en Información y Documentación. Volumen 1. Competencias y aptitudes de los profesionales europeos de información y documentación (2004), segunda edición completamente revisada, Madrid, SEDIC, ISBN 84-609-3634-1.

Svinicki, Marila y Barbara A. Schwartz (1991), Formación de profesionales y usuarios de bibliotecas: aprendizaje y diseño de instrucción, Madrid, Salamanca, Fundación Germán Sánchez Ruipérez, ISBN 84-86168-64-3.

Tejada Artigas, Carlos y Sergio Tobón Tobón (coords.) (2006), El diseño del plan docente en Información y Documentación acorde con el Espacio Europeo de Educación Superior: un enfoque por competencias, Madrid, Facultad de Ciencias de la Documentación, Universidad Complutense de Madrid, ISBN 84-96702-02-2.

Villaseñor Rodríguez, Isabel (2010), "Los estudios de usuarios de información como línea de investigación prioritaria en Bibliotecología y Documentación", en Memoria del XXVII Coloquio de Investigación Bibliotecológica y sobre la Información: la investigación y la educación bibliotecológica en la sociedad del conocimiento, México, Universidad Nacional Autónoma de México, Centro Universitario de Investigaciones Bibliotecológicas, pp. 161-175, ISBN 978-607-02-1424-0. 



\title{
Objetivos e perspectivas da investigação bibliotecária na sociedade da informação
}

\author{
EMIR José SuAIDEN \\ Universidade de Brasilia, Brasil
}

\section{O LEGADO DA SOCIEDADE PÓS-INDUSTRIAL}

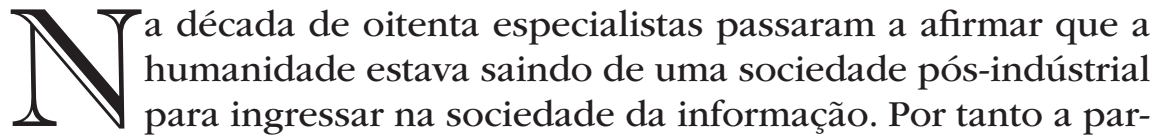
tir daquela época a riqueza, a hegemonia e o poder passavam a ser compartilhados pela busca, acesso, compreensão, transferencia e validação da informação. Poucos países da America Latina e do Caribe estavam preparados para desfrutar dessa nova sociedade, pois não se prepararam devidadamente na sociedade indústrial cujo legado na área da biblioteconomia foi marcado pela invisibilidade das estruturas informacionais. Conceitos antagonicos entre o profissional da informação e a comunidade, a dificuldade do livro e da biblioteca serem incluídas na agenda governamental e a falta de um público lector construiram uma imagen negativa da biblioteca e dos serviços de informação. Outro fenómeno foi a escolarização das bibliotecas públicas na America Latina que demonstrou com clareza a falta de bibliotecas escolares e aconstrução de usuários dependentes do processo informacional pois durante muito tempo a investigação era feita com a ajuda de diccionarios e enciclopédias que ajudaram a criar um usuário totalmente dependente.

Hoje ainda encontramos na America Latina pessoas que estão a um passo da vida universitária e encontram dificuldades para inter- 
pretar o texto escrito o que se caracteriza como uma inclusão precária na sociedade da informação. A inclusão precária de uma parte importante da comunidade aumentam a exclusão social e as desigualdades e conduz o país para a exclusão cognitiva, ou seja, a região fica imposibilitada de acompanhar o desenvolvimento do processo ensino-aprendizagem e se torna dependente no processo informacional. Essa dependencia compromete o desenvolvimento educacional e aumenta a exclusão social.

\section{Os DESAFIOS DA SOCIEDADE DA INFORMAÇÃO}

O grande desafio das estruturas bibliotecárias na sociedade da informação é a formação do usuário crítico, ou seja, um usuário com capacidade de agregar valor à informação, criticar e não aceitar passivamente o texto escrito e tambem participar do processo de tomada de decisão da biblioteca, seja para o processo de seleção e aquisição do acervo ou seja para a consolidação de uma política de informação que valorize o acesso livre. Essa sociedade é marcada pela intangibilidade, pela conectividade, pela velocidade (o usuário exije a informação em tempo real) e pela inovação. Porisso que se busca um novo modelo de biblioteca, baseada na informação bibliográfica, digital e virtual um modelo comumente designado como biblioteca híbrida. Nesse novo modelo a inclusão informacional é tão importante como a inclusão educacional, pois permite ao usuário ter acesso às principias fontes e bibliotecas do mundo. A inclusão informacional utiliza a alfabetização em informação, a inclusão digital e a competencia informacional.

Para acompañar e avaliar o desenvolvimento dos usuários a biblioteca necesita, cada vez mais, utilizar metodologías cualitativas nos produtos e serviços.

Até hoje as mais utilizadas foram a metodología etnográfica, o ponto focal, o discurso do sujeito coletivo e a PARA (Participatory Rural Appraisal).

Nos últimos anos o Instituto Brasileiro de Informação em Ciencia e tecnología vem se dedicando na avaliação dos seus produtos e 
serviços > para isso é necesario sempre da a palabra aos usuários. Até que ponto há clareza nas informações do site do Instituto?Qual o graú de satisfação do usuário nos accesos às bibliotecas digitais, ao programa de comutação bibliográfica, nos periódicos eletrônicos, nos programas de inclusão digital, no canal ciencia, nos cursos e eventos do programa de pesquisa e pós-graduação, no Serviço Brasileiro de Respostas Técnicas e na avaliação do ciclo de vida dos produtos? Para conhecer a resposta com detalles é que implantamos o projeto de avaliação dos produtos e serviços do IBICT.

\section{Projeto de AVAliação dos PRODutos E SERViços DO IBICT}

O trabalho de avaliação dos produtos e serviços de informação do Instituto com foco no usuário, está inserido no Plano Diretor do Ibict, com previsão de consolidação da avaliação do total de 15 produtos e serviços até o início deste segundo semestre de 2011. Estão consolidadas 12 avaliações que já foram entregues às respectivas unidades técnicas para análise. Após a conclusão do trabalho, existe o compromisso institucional de que a avaliação de produtos e serviços junto aos usuários se torne uma atividade contínua e sistemática no âmbito do Instituto, desenvolvida de forma articulada e integrada institucionalmente. Até 2015 o Instituto espera adequar seus produtos e serviços às reais necessidades dos usuários a partir da avaliação efetuada.

No desenvolvimento da metodologia para avaliação dos produtos e serviços, levaram-se em consideração os novos paradigmas gerados pela sociedade do conhecimento, que se desdobram em novas tecnologias de informação, convergência tecnológica, ambiente virtual, informação digital, sociedade em rede, perda do caráter sistêmico isolado que gera a necessidade de trabalho em rede -de forma compartilhada, com o uso dos padrões de interoperabilidade, software livre, etc.- e consequente democratização e universalização do acesso ao conhecimento.

A metodologia tem fundamento em três métodos. Optou-se pelas três abordagens a seguir descritas, porque se considerou que 
apenas um método não seria ideal para uma avaliação abrangente e consistente considerando-se a natureza e a diversidade dos produtos e serviços do Ibict:

1. Levantamento de dados qualitativos por entrevistas estruturadas e realizadas com dez usuários, a maioria com nível de pósgraduação em áreas multidisciplinares, a partir do método Micro Moment Timeline Interview, desenvolvido para a operacionalização da abordagem Sense-Making de autoria de Brenda Dervin (2003a, 2003b). A análise dos resultados foi realizada a partir da aplicação do Método dos Incidentes Críticos de Flanagan (1973). Para aplicação das entrevistas, foram treinados três bolsistas, que seguiram o roteiro elaborado de acordo com a abordagem SenseMaking.

Esta abordagem permite uma visão contextualizada das práticas informacionais dos usuários e enriquece a reconstrução das condições de uso dos produtos e serviços oferecidos.

2. Levantamento de dados quantitativos por formulários eletrônicos disponibilizados na Internet no site de cada produto e serviço. Para esse trabalho, foi utilizado o software Zoomerang, que tem atendido aos objetivos da avaliação por ser de fácil compreensão, por permitir exportação de dados para outros programas e por oferecer atualização e aprimoramento constantes no que se refere às possibilidades de análise de dados. Os formulários ficam on-line pelo período mínimo de seis meses para avaliação. Esta abordagem oferece a possibilidade de obter informações sobre a extensão do acesso, uso e grau de satisfação dos usuários em relação aos produtos e serviços.

3. Aplicação de checklist desenvolvido a partir das heurísticas de Jacob Nielsen (1992?, c2005a, c2005b, 2001?) e seus fundamentos teóricos para avaliação da usabilidade dos sites e páginas dos produtos e serviços, no que se refere à interação homemmáquina.

Este terceiro procedimento explicita a facilidade das interfaces com as quais os usuários se relacionam. 
Este procedimento é realizado em três etapas:

1. avaliação das páginas Web do produto/serviço por um especialista em usabilidade a partir das heurísticas de Nielsen;

2. avaliação das páginas Web do produto/serviço pelo especialista em usabilidade, com a participação individual de quatro a cinco usuários;

3. a avaliação é complementada com as observações registradas pelos usuários, a partir das entrevistas da avaliação qualitativa ou por meio das respostas à pergunta aberta do questionário da avaliação quantitativa.

As ocorrências de não adequação às heurísticas foram apoiadas no nível de gravidade dos problemas. Esses níveis vão desde solução de baixa, média e alta prioridades de correção, até o nível de que é necessário haver uma correção imediata.

O Ibict contratou, também, um consultor para preparar um quadro geral de problemas de usabilidade detectados nos sites dos produtos e serviços do Ibict, que são comuns a todos esses produtos/serviços e para complementar a avaliação já realizada com uma proposta de aprimoramento a partir das novas tecnologias e ferramentas disponíveis para avaliação de websites.

É importante ressaltar que nos três procedimentos o ator principal é o usuário.

Software: www.zoomerang.com

\section{REFERÊNCIA}

www.ibict.br 



\title{
Retos en la investigación de la producción editorial en el medio digital
}

\author{
Georgina Araceli Torres Vargas \\ Instituto de Investigaciones Bibliotecológicas \\ $y$ de la Información, UNAM
}

\section{INTRODUCCIÓN}

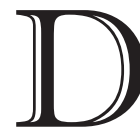

esde su aparición el campo editorial se basó en un entramado de relaciones entre diferentes actores como el editor, el autor y el librero, que hizo posible la generación de publicaciones.

A través de estas relaciones se definió el rol de cada participante y es así como se delineó la figura del autor. Si bien hay un momento del siglo xviII en el que aparece la función de autor, es hasta la aparición de la industria editorial cuando se formaliza su estatus, a partir de que se hace pública su obra. ${ }^{1}$

Esta situación llevó casi de inmediato a la aparición del derecho de autor como medio para regular la relación mercantil que se requería entre autor, editor y librero. Fue precisamente a solicitud de los libreros que se le reconoció al autor la propiedad literaria, aunque se la limitó en cuanto a su duración mediante el concepto de dominio público.

En este contexto tanto los actores de la cadena de producción editorial como sus funciones y relaciones se mostraron con cierta estabilidad y por ende, como el modelo de producción editorial.

En tiempos más recientes, tras la aparición de las publicaciones digitales (sean libros, revistas u otro tipo de publicaciones) se co-

1 José Cordón García (2011), Gutenberg 2.0: la revolución de los libros electrónicos, Gijón, TREA, p. 26. 
menzó a hacer mención de un cambio sustancial en la producción editorial. Sin embargo a la fecha se observan muy pocos estudios que muestren cuáles son esos cambios, en qué medida se dan y de qué forma nos afectan. En principio se tuvo mayor preocupación por analizar si desaparecería el libro impreso y si se sustituiría éste por el libro electrónico, discusión que en la actualidad considero que no tiene gran relevancia, puesto que de forma casi generalizada se tiene la convicción de que tanto el libro impreso como el electrónico tienen su sitio.

En el ámbito de la bibliotecología y de los estudios de la información se han realizado muy pocos estudios sobre el fenómeno que se vive en este medio de producción editorial. Sobre todo nos hemos avocado a la descripción de los nuevos medios y productos que aparecen en el análisis de la adquisición de documentos digitales para el desarrollo de colecciones, en el estudio de la publicación a través de propuestas como el Open Access (acceso abierto) y en el análisis de los problemas en materia de derechos de autor.

Dada esta carencia se planteó la necesidad de llevar a cabo una investigación sobre el tema. Dicha investigación se relaciona con el estudio de la biblioteca digital; es decir, la publicación digital se analiza como uno de los componentes básicos para la construcción de bibliotecas digitales.

Todo esto se dice en el supuesto de que si no se conoce qué ocurre con la publicación digital, difícilmente podremos planear y diseñar bibliotecas que contengan colecciones digitales.

Si bien este texto no muestra los resultados de la investigación que hace poco dio inicio, sí hace un primer acercamiento a las siguientes cuestiones:

a) la generación de publicaciones digitales a nivel mundial, y

b) la producción editorial en el medio digital.

\section{LA GENERACIÓN DE PUBLICACIONES DIGITALES A NIVEL MUNDIAL}

El interés por analizar el desarrollo del libro electrónico y sus consecuencias aparecieron a finales de la década de 1980. Antes, en 
1984, Efrem Sigel $^{2}$ analizaba el futuro que le esperaba a la biblioteca tras el desarrollo creciente de la publicación electrónica y aseveraba lo siguiente:

En los años recientes se ha dicho mucho sobre la llegada de la "sociedad sin papel” y el reemplazo de publicaciones impresas por las ediciones periódicas o libros "electrónicos". Los bibliotecarios tienen mucho entusiasmo en cuanto a desarrollos de tecnología que producirá la publicación electrónica de todo el texto de algunos materiales, así como de fuentes secundarias. Sin embargo, en el presente, es relativamente poco el material completo disponible[...]. ${ }^{3}$

Este interés por la publicación electrónica se hizo más evidente en la década de 1990 como producto del contexto tecnológico en donde se popularizó el uso de las tecnologías de la información y de la comunicación, que por entonces se empezaron a llamar "nuevas tecnologías". A mediados de esta misma década se realizó una reunión en Bolonia, en donde especialistas de diferentes áreas debatieron sobre el futuro del libro.

Entre los temas cruciales de la época se mencionó a la "desintermediación", en donde el autor de forma directa podría autoeditar y autopublicar sus obras. Los editores se preocuparon por ver qué posición podrían ocupar en ese escenario, en donde imperaría la generación de contenidos en línea sin la intervención de los actores tradicionales. ${ }^{4}$

Pero como algunos autores lo señalan, hacia el año 2000 las grandes expectativas del decenio anterior sobre el futuro de la edición se comenzaron a desdibujar y aparecieron dudas sobre la concreción de los cambios vaticinados, ya que entre otras situaciones se dio el cierre de divisiones de libros electrónicos de diversas editoriales, dada la escasa compra de estos documentos.

2 Cfr. Efrem Sigel (1984), Libros, bibliotecas y electrónica: el futuro de la comunicación impresa, México, EDAMEX.

3 Ibid., p.105.

4 José Cordón García (2010), "Los libros electrónicos: la tercera ola de la revolución digital”, pp. 53-80, en Anales de Documentación, vol. 13, p. 54. 
Si bien ya existen diversas publicaciones en línea, desde el sector editorial todavía se observa un ingreso lento de esta industria en el medio digital en comparación con otras industrias como la discográfica, que completó su ingreso en diez años transformando sustancialmente su modelo de negocio. Para algunos analistas, es probable que el e-book no exceda más del 30\% del mercado total en la próxima década, ${ }^{5}$ con diferencias entre sectores sociales, subsectores (infantil, juvenil, universitario) y géneros (ficción, novela, etcétera).

En el Primer Simposio Internacional del Libro Electrónico que se celebró hace unos días en México se mencionó que un $93 \%$ de los libros que se publican en Iberoamérica son aún en papel, y el $7 \%$ restante se lo reparten las ediciones electrónicas y los audiolibros.

En lo que corresponde a México cabe mencionar que este año por primera vez la Cámara Nacional de la Industria Editorial Mexicana (Caniem) abrió la convocatoria para premiar en la categoría de libro digital y que sólo se presentó uno a la convocatoria. El premio quedó desierto.

La industria del libro digital en México está todavía en ciernes y representa un reto para el sector editorial, el cual manifiesta interés pero también mucho temor ante la incertidumbre de aspectos como la protección legal de los contenidos. El vicepresidente de la Caniem asevera que hoy en día la publicación de obras en formato digital no es rentable para las casas editoriales mexicanas y que aunque está presente la demanda -ya que la piratería de libros en formato digital sumó 88 millones de descargas ilegales- no se ha encontrado la fórmula para ofrecer más contenidos de forma legal. Es una realidad que la industria del libro digital en México está atrasada. $^{6}$

Como productor de libros México ocupa el noveno lugar mundial, frente al cuarto de España y el quinto de Brasil. Se afirma que

5 Roberto Igarza (2010), Ebooks: hacia una estrategia digital del sector editorial. Análisis preliminar para el desarrollo de una plataforma de distribución de contenidos digitales, Argentina, Cámara Argentina del Libro, p. 17.

6 Alejandro Flores, "Medirán el impacto del e-book", en El Economista, disponible en: http://eleconomista.com.mx/entretenimiento/2011/09/18/mediran-impactoe-book. 
son tres los factores que han impedido el despegue de la actividad editorial: el rezago educativo, la falta de hábito de lectura y la pérdida de capacidad de compra. ${ }^{7}$

En este contexto considero que la gran implosión del libro digital de la que tanto se habla se refiere más al uso de los dispositivos para la lectura de libros que a los contenidos, situación que se relaciona de forma directa con la producción editorial de publicaciones digitales.

\section{LA PRODUCCIÓN EDITORIAL EN EL MEDIO DIGITAL}

Comencemos por señalar que el proceso de producción editorial tradicionalmente se compone de tres grandes etapas:

1. Coordinación editorial. Corresponde al director o al consejo editorial.

2. Labor editorial. Comprende la traducción, revisión, corrección de estilo, etcétera.

3. Artes gráficas. ${ }^{8}$

En el modelo de producción editorial de obras impresas la editorial se agrupa en departamentos que tienen funciones particulares, pero por lo general se compone de los siguientes:

a) Editorial

b) Diseño y producción

c) Mercadotecnia

d) Contabilidad

Los tres primeros comprenden la selección del manuscrito, la edición y fijación de precios, el establecimiento de especificaciones de diagramación y la elaboración de artes finales, entre otras cues-

7 Miguel Ángel Guzmán (2010), "Producción editorial o cómo resolvemos las cosas", pp. 131-148, en Quehacer editorial, núm. 7, disponible en: http://www. quehacereditorial.com/sitio/anteriores/qe07.html, p. 145.

8 Op. cit., p. 139. 
tiones. El establecimiento de mecanismos de distribución y ventas corresponde al departamento de mercadotecnia.

Esta cadena de producción editorial prevalece en el medio de los impresos. Si bien a partir de la década de 1980 se dan nuevas técnicas para la reproducción de documentos y las publicaciones se especializan, no se puede hablar de una transformación de fondo en el proceso de producción editorial.

En años más recientes, tras la aparición de herramientas de lectura de documentos electrónicos, se vuelven a tener grandes expectativas sobre la popularización de la publicación digital.

Lo cierto es que con el paso del tiempo y tras el desarrollo de las tecnologías de la información y de la comunicación, así como de las técnicas para la reproducción y circulación de los documentos, se ha establecido una infraestructura orientada a la creación y desarrollo de un mercado de servicios de información, en cuyo centro se encuentra el documento digital. Esto ha traído como consecuencia la modificación de nuevas formas de publicación, transferencia, difusión y uso de los documentos.

A la fecha se considera que la industria editorial está compuesta por los establecimientos que se dedican al diseño, la edición y la venta, actividades necesarias para la producción y distribución de libros. ${ }^{9}$ Esos establecimientos pueden publicar libros en forma impresa, electrónica o como audio. Sin embargo la aparición de otras alternativas y de alianzas entre industrias de diferente naturaleza para la publicación de documentos digitales hizo surgir la industria de contenidos, que abarca a toda la producción digital, pensada por las nuevas tecnologías de información y comunicación, para la convergencia digital. Es decir, esta industria abarca nuevos modelos de negocios, nuevas estructuras tecnológicas, nuevos lenguajes para esos medios digitales, nuevas maneras de relacionarse con los diferentes públicos, nuevos profesionales capacitados para nuevas demandas que pueden ser planteadas y desarrolladas independientemente del tiempo, el espacio o la localización geográfica, pues

9 Barners Report (2011), Book publishing industry, USA, Barners. 
incluyen la interactividad y la movilidad posibilitada por celulares y computadoras de mano. ${ }^{10}$

Es así como el mercado de la publicación digital experimenta transformaciones significativas que afectan a toda la cadena de producción editorial, lo que determina cambios de funciones en las tareas tradicionales de autoría, intermediación y distribución. En el ámbito del impreso la exigencia de la publicación implica necesariamente a un autor, un editor, un impresor y un distribuidor. Mientras que en el modelo tradicional la publicación transita por la figura del editor que es quien le concede crédito y visibilidad a una obra, en el digital esta relación no necesariamente se establece, puesto que se amplía el número de autores y se transforman las funciones. De esta forma un autor puede decidir conservar la relación con su editor o dirigirse directamente a un distribuidor digital. O puede autoeditar a través de un sitio web personal o convertirse en su propio distribuidor buscando el apoyo de librerías digitales.

La edición digital le ha abierto sus puertas a miles de autores que han visto en las editoriales y distribuidoras digitales una alternativa para publicar sus obras. Se trata de grandes emporios como Amazon que ha creado la Kindle Digital Text Platform (Plataforma Digital de Textos Kindle) donde el autor puede subir sus obras a la red y venderlas, o recurrir a Apple que a través de Ibookstore desarrolla el mismo servicio. Barnes and Noble hace también lo propio y la tendencia es la misma en otras empresas. Estas iniciativas hacen tambalear la posición del editor tradicional y su poder de selección, producción y distribución del libro, pero también elimina una función esencial del circuito editorial, como es la del arbitraje que permite articular controles de calidad entre todo aquello que se pretende publicar. ${ }^{11}$

La visibilidad de un producto está en estrecha relación con el grado de receptividad que sea capaz de despertar en el usuario,

10 Cosette Castro (2008), Industrias de contenidos en Latinoamérica, Argentina, CEPAL, disponible en: http://www.eclac.org/socinfo/noticias/noticias/2/32222/ GdT_eLAC_meta_13.pdf.

11 Manuel Gil (2010), El nuevo paradigma del sector del libro, Madrid, Trama. 
pero también con factores derivados como son la presencia continuada en puntos de venta, por ejemplo, la librería, o los espacios publicitarios de los medios de comunicación. Lo que el modelo digital permite es la multiplicación de los espacios de intervención para el editor.

Pero hay aquí algo realmente novedoso y es la aparición de empresas que no responden exactamente a los modelos anteriores, como los agregadores, que difieren considerablemente del papel de los distribuidores tradicionales. El cometido de estos agregadores es la creación y el mantenimiento de colecciones de libros electrónicos y otros materiales, de tal manera que éstos puedan ser consultados y leídos por los usuarios finales mediante suscripción o compra. La creación y mantenimiento de estas colecciones representa la participación de un número variable de instituciones intermediarias. Entre éstas están aquéllas que adquieren los derechos de los editores para transformar o distribuir los contenidos en forma digital, y las bibliotecas que compran los derechos de acceso para los miembros de las instituciones a las que pertenecen en determinadas condiciones. Las bibliotecas generalmente no son propietarias de los contenidos, sólo tienen acceso a ellos a través de la compra de licencias para su consulta, licencias que les venden los editores.

Algunos distribuidores tradicionales también han entrado en el terreno de la venta de contenidos digitales, reuniendo a grupos de editores que comienzan a constituir consorcios para ofrecer sus contenidos digitalizados a clientes de diversos tipos.

Todos estos procesos están provocando el reforzamiento económico de las posiciones intermediarias. La multiplicación de los usos y de los sistemas de acceso determina esta fragmentación potencial de los contenidos en línea siguiendo los flujos financieros y comerciales generados por una oferta cada vez más amplia. La actividad de intermediación se reviste de un carácter que es cada vez más complejo.

Los nuevos intermediarios, como los agregadores, o los consorcios de editores constituidos en distribuidores digitales, se enfrentan a un doble reto: por una parte adaptarse a la fragmentación cre- 
ciente de un mercado que exige una adecuación a los diferentes perfiles de demanda, y por otra encontrar el modelo de negocio que mejor se adapte a una oferta y una demanda en permanente transformación.

Muchos de los problemas existentes con los libros que son documentos digitales se relacionan con la naturaleza misma del producto en la que confluyen canales de diferente filiación y naturaleza comercial. De esta manera la cadena de la publicación digital se caracteriza por una segmentación en varios niveles: tecnológico (multiplicidad de formatos), logístico (multiplicidad de plataformas de distribución), comercial (multiplicidad de tarifas), jurídico (multiplicidad de formas de protección) y de mercado (multiplicidad de ofertas fragmentadas, sin coordinación ni compatibilidad entre ellas). ${ }^{12}$ Por otra parte la edición digital exige competencias diferentes a la edición analógica y determina la aparición de funciones y especialidades nuevas en la cadena de la publicación tales como: productores de metadatos, agregadores, productores de bases de datos, distribuidores de servicios digitales, gestores de información, servicios de digitalización, etcétera.

El editor por su parte tampoco necesita del distribuidor. Un editor puede distribuir a sus autores o asumir las funciones que en el modelo analógico estaban completamente diferenciadas.

Como puede verse estudiar la publicación de documentos digitales es imprescindible para entender la naturaleza de los fenómenos y problemas inherentes a la biblioteca digital en razón de sus contenidos; lo que nos dirige posteriormente a la creación de colecciones y servicios digitales. Sin contenidos no es posible construir bibliotecas digitales, o simplemente esto se convertirá en un cúmulo de enlaces a otras colecciones y a otros portales.

No obstante esta relación documento digital-biblioteca digital, es necesario distinguir y separar el estudio del documento, ya que al atarlo en su totalidad a la biblioteca se limita el alcance del análisis

12 Françoise Benhamou (2010), "Modèles économiques d'un marché naissant: le livre numérique", en Prospective: économie de la culture et de la communication, núm. 6, p. 6. 
y se corre el riesgo de seguir en la tónica que hasta ahora se ha venido estudiando al documento digital, que consiste básicamente en describir las publicaciones digitales consideradas como objetos tecnológicos y en evaluar los sistemas proveedores de publicaciones y los vendedores de licencias de acceso a los contenidos.

En este sentido es necesario tomar cierta distancia de la biblioteca para poder analizar el modelo de producción editorial digital lo más objetivamente posible. Una vez analizado será posible establecer una crítica del acceso que se permite a estos documentos, pero desde una óptica más amplia de los medios de información que no se circunscriba exclusivamente a la biblioteca, sino que se abra a otras alternativas que se dan a partir del uso de las TIC, como lo puede ser el repositorio institucional o los servicios web.

Una forma de acercarse al estudio de la producción y uso de los documentos digitales puede ser a través del diseño de modelos. El desarrollo de modelos de producción y el uso de documentos digitales estarían dirigidos a innovar la presencia social de la biblioteca como institución, al generar alternativas que integren la idea de biblioteca al entorno de los sistemas de información. Vista así, la biblioteca tendrá más posibilidades para ofrecer servicios y complementarlos a través de diversas vías de información. Después de todo, la biblioteca es un actor potencialmente fuerte en la cadena de producción editorial y es momento de reposicionarla como tal en el medio digital.

\section{Conclusiones}

El interés por analizar el desarrollo del libro electrónico y sus consecuencias apareció desde finales de la década de 1980, pero hasta la fecha se ha avanzado muy poco en el ingreso de la industria editorial en el medio digital, en comparación con industrias como la discográfica. La producción de libros electrónicos es todavía muy baja y representa apenas el 30\% de la producción editorial total.

En México no se observa una producción aceptable de libros electrónicos, entre otras razones porque todavía no es rentable este 
tipo de publicación, pese a que la demanda se ve reflejada en el gran número de descargas de libros de forma ilegal, que se dan a diario a nivel mundial.

Puesto que hay estadísticas que constatan que el desarrollo de la industria editorial digital está muy poco desarrollada, se puede afirmar que el gran crecimiento del que tanto se habla en la literatura sobre el tema se refiere más a la proliferación de lectores de libros, que al de contenidos digitales.

Para fortalecer la producción editorial en el medio digital se requiere analizar las transformaciones que se están dando en la cadena de producción editorial, a fin de poder intervenir positivamente en esta nueva forma de crear, publicar, difundir y comercializar las publicaciones digitales, en un entorno donde los diferentes actores tengan más clara su nueva función.

En esta cadena editorial la biblioteca digital debe posicionarse como un eslabón que logre articular estos nuevos procesos con otras formas de crear y administrar colecciones digitales. La biblioteca y las publicaciones digitales deberán coordinarse en un nuevo escenario, con las nuevas reglas del juego. 



\title{
Bibliografía: la raigambre humanista de la bibliotecología
}

\author{
Héctor Guillermo Alfaro López \\ Instituto de Investigaciones Bibliotecológicas \\ $y$ de la Información, UNAM
}

Para Daniel de Lira.

El peñasco de Sísifo siempre vuelve a caer, $u$ otro justo a su lado-pero el destino de Sísifo no es una maldición; es simplemente la condición bumana, que no conoce lo definitivo ni perfecto-. O mejor, que consiste, como en una operación de alquimia, en convertir lo relativo en absoluto, en construir algo sólido con los materiales más frágiles.

Tzvetan Todorov

10 ibliotheca Universalis, sive Catalogus omnium scriptorum locupletissimus, in tribus linguis, Latina Graeca et Hebraica: extantium et non extantium, veterum et recentiorum in bunc usque diem, doctorum et indoctorum, publicatorum et in Bibliothecis latentium [...] (Zurich, 1545). Tal es el dilatado y litigoso titulo latino de la opus magna de Conrad Gesner (1516-1565), considerado con justicia el padre de la bibliografía moderna. Con todo y que alguna voz, inconforme y transida de pretendida originalidad, le atribuyese tal paternidad al abad del monasterio benedictino de Spanheim (en la diócesis de Maguncia) Johan Tritheims (1462-1516), conocido entre la cofradía humanista como Trithemius: por el hecho de ser el primero en dedicarse profesionalmente a compilar repertorios bibliográficos como bibliotecario y catalogador en su monasterio. Y aunque Trithemius precedió con su notable labor bibliográfica la bibliografía de C. Gesner, careció de la amplia visión de éste último. El sabio de Zurich tuvo la lucidez para ver todo aquello que no se ve en una bibliografía pero que está siempre presente y que es su fundamento último: el aura 
que la envuelve otorgándole su sentido, de ahí que en verdad sea el indiscutido padre de la bibliografía.

Lo que C. Gesner contempló más allá del escorzo técnico para elaborar su bibliografía fue el fundamento humanístico que le da sentido. Pero hay que subrayar que semejante concepción humanística de la bibliografía no sólo era consecuencia de la formación humanística de C. Gesner, o de que el contexto sociocultural del momento aún se encontraba permeado por las tendencias humanistas propias del Renacimiento. Éstos son elementos externos que por supuesto están presentes y en buena medida son determinantes en la bibliografía concebida y elaborada por C. Gesner; mas para él la bibliografía en sí y por sí misma ya era humanista: un sofisticado artefacto de información y conocimiento que expresa la naturaleza humana. La visión gesneriana por otra parte lleva a plantearnos las preguntas: ¿cuál y cómo es ese fundamento humanístico de la bibliografía? Y ¿por qué la bibliografía es la raigambre humanista de la Bibliotecología?

Conrad Gesner encarna el ideal del hombre renacentista: era médico, botánico, zoólogo, filólogo y traductor al latín de textos griegos. Signado por el espíritu de la época se dio a la tarea de recuperar las obras del pasado clásico, griegos y latinos, incluyendo árabes y autores recientes, en todo lo relativo a las ciencias naturales y médicas. Esta recuperación crítica que lleva a cabo con su gran bibliografía tenía la finalidad de alcanzar el conocimiento para comunicarlo a los demás, lo que implica una invitación a participar en la investigación posterior: que el conocimiento alcanzado por los antiguos fuera estímulo y base para la generación de nuevos conocimientos, enriqueciendo así las artes liberales. La gran obra del sabio de Zurich es conocida de forma compendiosa como Bibliotheca Universalis, con lo que se remarca externamente su indeleble sello humanista: la dimensión universal de la investigación, del conocimiento entendido como modelo enciclopédico de la cultura trilingüe (como lo indica en el título: latina, griega, hebraica) que ha conformado a la civilización cristiana occidental. La salvaguarda de ese patrimonio cultural del pasado, a la par de significarse como un resumen final de toda una época, tenía también un senti- 
do práctico: conformar el instrumental técnico más avanzado para profundizar en la información bibliográfica; lo cual a su vez debía conducir a la disponibilidad material de los libros, haciendo que resultaran mayormente localizables y accesibles. De ahí que C. Gesner se postulara por la creación de instituciones estables y duraderas para la conservación y accesibilidad de ese patrimonio cultural de la colectividad que son los libros. Por vía de tales instituciones, como por ejemplo las bibliotecas, se mostraría de mejor forma la función instrumental de su repertorio; con ello se garantizaría el acceso a la mayoría de los libros reunidos y bien ordenados en los lugares idóneos, así se cumpliría con el fin de servir al público satisfaciendo al mismo tiempo su demanda de información. Todos estos atributos de la Bibliotheca Universalis son aquello que puede caracterizarse como su barniz humanista, pero, como ya se había adelantado, es en la esfera de lo intangible donde se imprime de manera perenne la esencia humanista de la bibliografía conforme la concibió C. Gesner.

El pensador franco-búlgaro Tzvetan Todorov ha codificado los elementos medulares del humanismo, con lo que les ha dado una más sólida y sistemática concatenación, por lo que su modelo nos puede brindar una visión amplia y precisa de esta temática así como elementos específicos para dilucidar la cuestión humanista de la bibliografía. ${ }^{1}$ Todorov parte de la enunciación de las tres manifestaciones de lo humano en la interacción entre los hombres. "La autonomía del yo" que es la fuente de mi acción, por lo que corresponde a la capacidad humana de eludir cualquier determinación. "La finalidad del tú" es la base de la sociabilidad constitutiva de los hombres y de la necesidad que tienen unos de otros: pues en tanto que seres conscientes y comunicativos buscan la celebración del otro, que es la culminación de esa relación necesaria. "La universalidad de los ellos" es la contrapartida de la pertenencia de todos los seres humanos a una misma especie viviente.

1 T. Todorov (2008), El jardín imperfecto. Luces y sombras del pensamiento bumanista, España, Paidós. 
El humanismo afirma que es preciso servir a los seres humanos uno por uno, esto es, de manera individual, específica y concreta, no en la abstracción de las categorías. De ahí que cuando el yo autónomo hace del tú una finalidad se establece una relación concreta entre hombres de "carne y hueso", con lo que a su vez se conforma el espacio público desde el que interactúan. Cada uno de nosotros cuando hace de los otros su finalidad estatuye la universalidad de los ellos, donde todos exhiben su pertenencia a la misma especie. Con lo que el espacio público se desdobla de la esfera de lo individual a la de lo universal y viceversa. La necesidad que tienen unos de otros se expresa en el espacio público a través de valores éticos, racionales, políticos y comunicacionales. El espacio público comprendido desde la perspectiva humanista de Todorov se convierte en ámbito de realización de lo humano por mediación de las interacciones que conllevan los siguientes valores: el hombre no se da la humanidad a sí mismo, sino en relación con el otro hombre. La finalidad del tú implica éticamente la celebración del otro al res-petarlo como ser humano libre e independiente, constructor de su propio destino. También en la interacción social se comprende al tú como hombre racional susceptible de recibir y brindar conocimiento signado por el pluralismo, no por las coacciones segmentadoras y limitantes del dogmatismo: lo humano del hombre no es que comprende el mundo sino que se comprende con los demás hombres. Los valores políticos del humanismo hacen del espacio público el ámbito de la democracia por antonomasia: espacio de reconocimiento de la igualdad entre el yo y el tú. Pero para que tales valores se expresen y realicen se requiere de la, parafraseando a Habermas, "acción comunicativa".

El fundamento de la comunicación es el lenguaje. Para la gran filósofa Hannah Arendt el lenguaje es el hontanar de donde brota la formación de lo humano. La comprensión y expresión, elementos sustanciales del lenguaje, permiten la apertura hacia los demás: el yo autónomo abierto por mediación de la palabra hacia la finalidad del tú. No es la palabra en sí misma, sino la palabra dicha, intercambiada y aceptada lo que nos humaniza. Con el lenguaje comunicamos y nos hacemos partícipes de los valores éticos, racionales 
y políticos, lo que nos brinda la humanidad. Tal es el profundo sentido del humanismo de la Modernidad, del cual hace eco la $\mathrm{Bi}$ bliotheca Universalis de C. Gesner.

Un acontecimiento fundamental que acompaña ceñidamente al humanismo de la Modernidad es la creación de la imprenta de tipos móviles de Gutemberg. Había caído la barrera de la restringida producción de los primorosos libros manuscritos, con la imprenta se iniciaba la era de la producción masiva de impresos. Con lo que grandes beneficios, pero también peculiares problemas, se hacían ahora presentes. A la par que el programa renacentista recuperaba los textos de la cultura clásica éstos podían imprimirse ampliamente, así como también las propias obras de los humanistas que se daban a la labor de exhumar los textos de los antiguos griegos y latinos. Con lo que se satisfacía la creciente demanda de un público lector. Por lo que puede decirse que aparte de que la imprenta de tipos móviles es un artefacto técnico que nace signado por las profundas fuerzas del contexto humanista del Renacimiento, de manera análoga los libros producidos por tal artefacto se encuentran nimbados por el espíritu humanista tanto en su concepción material como textual. Por lo que bien puede decirse que el libro impreso que nace con la Modernidad es un preclaro logro humanista. Pero tales beneficios venían aparejados con problemas, que de hecho aún siguen gravitando hasta nuestros días, como la sobreabundancia de libros, su almacenamiento y la cuestión candente de cómo guiarse en ese maremagnum de impresos.

A este panorama de beneficios y problemas de la imprenta hizo frente C. Gesner. Él se daba clara cuenta de que se estaba consolidando una cultura impresa -como de manera análoga en la actualidad somos testigos de una ascendente cultura visual con la desbordada proliferación de imágenes- por lo que tenía que exaltar y consolidar los beneficios, a la vez que debía dar respuesta a los problemas que todo ello traía aparejado, desde la plataforma humanista. Volviendo una vez más al extenso título del repertorio bibliográfico gesneriano, en él queda claramente de manifiesto el espíritu humanista que le da forma: el universalismo enciclopédico, la pluralidad inclusiva, la cultura sin fronteras, la apertura y valori- 
zación por los logros humanos del conocimiento: lo que en suma significa el reconocimiento del otro como ser humano. Veámoslo con detenimiento.

C. Gesner estimaba que un libro por sí mismo y en solitario brinda un conocimiento específico de aquello que trata, con lo que se expresa no sólo el conocimiento, sino también el vivir y el pensar del autor: nuestro bibliógrafo como autor de obras importantes en las distintas ramas del conocimiento que trató sabía muy bien esto. En tales aspectos de una obra se vislumbra ya la dimensión humana que la alienta. Pero tal dimensión se expresa con mayor nitidez y plenitud cuando cada libro deja de ser una voz aislada en medio del vertiginoso territorio de la producción escrita para integrarse en una estructura sistemática de organización cognitiva.

Cuando cada una de las voces aisladas de los libros se integra a la partitura de la bibliografía pasan a ser acordes de la gran sinfonía de la información y el conocimiento. Lo que de humano se encuentra en potencia en cada libro se realiza en acto humanista en la bibliografía. Acto humanista que por fin acaba consumándose en el espacio público a través de la interacción concreta del yo y el tú. El tránsito que va del libro aislado a la bibliografía es lo que permite contestar la pregunta de cuál es el fundamento humanista de la bibliografía; mientras que el paso de ésta a su circulación pública posibilita responder al cómo es la fundamentación humanista de la bibliografía.

A diferencia de Trithemius, que sólo pretendía hacer una compilación enumerativa con su repertorio, C. Gesner buscaba programáticamente con su bibliografía conjuntar la multiplicidad de conocimientos del pasado y del presente. Lo que implícitamente conllevaba la preservación de las formas de vida de una civilización; esto es, el sentir, el actuar y el pensar de diversas sociedades a través del tiempo, que podría resumirse con el concepto de mentalidad colectiva. Esta visión integradora y plural pone de manifiesto en el artefacto bibliográfico la identidad humana, signada por la razón y la libertad. El acto creador definitorio de humanidad y característico de la humanidad se muestra en toda su magnitud en la comunión de obras que lleva a cabo una bibliografía, en ella el yo 
y tú de los autores dialogan idealmente teniendo como trasfondo la universalidad de los ellos, propia de nuestra especie viviente.

La esencia humanista de los repertorios fue asumida y desplegada de manera análoga largo tiempo después en todas sus posibilidades por el padre de la bibliografía en México, Juan José Eguiara y Eguren. Quien con su Bibliotheca Mexicana buscaba mostrar la identidad humana del pueblo mexicano a través de las obras de sus notables sabios. La bibliografía de Eguiara y Eguren daba un panorama general de la cultura mexicana sustentada en una filosofía de la historia, que le servía para rebatir las opiniones negativas o de desconocimiento que se tenían en España y, en términos generales, en Europa respecto a México. A la par la titánica Bibliotheca Mexicana pasaba a convertirse en el espejo en que los propios mexicanos contemplaban su propia humanidad valorizando con ello las peculiaridades de su historia y creatividad. Así el padre de la bibliografía mexicana comulgaba con el padre de la bibliografía moderna al comprender la esencia humanista del repertorio bibliográfico.

Como ya se mencionó palabras atrás, C. Gesner hizo frente a algunos de los problemas que acarreó la invención de la imprenta de tipos móviles como fueron la sobreabundancia del almacenamiento de los impresos, así como una guía ante tal cantidad. Con la Bibliotheca Universalis dio respuesta a semejantes problemas: el objetivo primario era que por mediación de ella se pudiera alcanzar el conocimiento y que a su vez se comunicara a los demás. Mas, para que tal objetivo se alcanzara, el repertorio tenía que fungir también como instancia que habría de proporcionar al lector en general elementos para hacer una selección motivada, evitando así extraviarse en la creciente jungla de impresos, y respetando la elección de cada cual. Al lector se le ofrecía un repertorio plural de autores y obras fundamentales ante las cuales estaba en completa libertad de elegir. El otro objetivo era la salvaguarda del patrimonio del pasado y del presente en los lugares adecuados dentro de los cuales debía encontrarse perfectamente organizado y localizable, ofreciéndoselo a todos los lectores, para lo cual la Bibliotheca Universalis proporcionaba los instrumentos necesarios. 
Oportunidades y retos en la formación, investigación y aplicación...

A estos objetivos acompañaba el aura humanista, la cual se desplegaba en el espacio público: los efectos expansivos del repertorio gesneriano se dejan sentir centralmente en la acción comunicativa entre el yo y el tú reales. Una bibliografía en cierto modo también puede definirse como un lenguaje que es suma de lenguajes. Y en cuanto tal es un complejo de información y conocimiento de la propia civilización que lo ha generado. C. Gesner al configurar su Bibliotheca Universalis era conciente de que en ella, por mediación del lenguaje, una civilización, una nación o un pueblo expresaban su unidad espiritual, confirmando el trabajo de la mente por superarse, por encontrar y mostrar su propia esencia. Con lo que además se revelaba su identidad, un origen y una finalidad comunes, todo esto plasmado en el lenguaje de las obras impresas: esto nos recuerda que la bibliografía es uno de los campos de actividad del sistema de comunicación social. Por lo que al ser una base de información configurada por el lenguaje, su ámbito de inserción lógico e inmediato es el espacio público. Lo que significa que los repertorios no quedan sólo circunscritos a los especialistas.

El lenguaje de una comunidad articulado en la información y el conocimiento del repertorio asimismo hace las veces de caja de resonancia del lenguaje vivo de la comunidad, de ahí la circulación del lenguaje entre uno y otro ámbito. Por lo que donde actúa de forma expansiva la bibliografía es en el espacio público: al mostrar lo más granado y selecto del conocimiento acumulado a lo largo del tiempo, a la propia sociedad que lo ha generado, le permite guiarse entre la abundancia de la información impresa y de los lugares donde puede encontrarla organizada. Pero más aún, al circular entre los intersticios culturales del espacio público la bibliografía hace que su lenguaje de lenguajes, transmisor de información y conocimientos, se recicle entre el yo autónomo y la finalidad del tú. Con lo que los valores humanistas (éticos, racionales y políticos) se transmiten por la acción comunicativa, como lo caracteriza el modelo de Tzvetan Todorov. La información y el conocimiento articulados en y con el lenguaje, que brinda el repertorio, se transfigura así en la fuente en la que se expresa la forja de la humanidad que se da entre un hombre y otro: el yo celebra al tú al comprenderlo como ser huma- 
no libre y racional susceptible de brindar y recibir un conocimiento abierto y plural. Con lo cual se fomenta el sentido de la democracia. De esta forma la bibliografía viene a representar también el trasfondo ideal de los ellos con que se enmarca por vía de la universalidad la interacción del yo y tú: humanismo real.

En resumen, la respuesta a ¿cómo es el fundamento humanista de la bibliografía? es que en una primera intención la Biblioteca Universalis buscaba resolver algunas de las situaciones problemáticas producidas por la actividad de la imprenta de tipos móviles; pero en la medida en que la bibliografía es uno de los campos del complejo sistema de la comunicación social, la intención inicial del repertorio de Gesner va mucho más allá. Con lo que quedará establecida la trayectoria de la bibliografía moderna: signar con su impronta humanista el espacio público, así es como alcanza su realización integral. Todo lo cual nos conduce al umbral del problema central de la presente indagación: la bibliografía como la raigambre humanista de la Bibliotecología.

Contestando al cuál y el cómo de la bibliografía se dejaba establecido su fundamento humanista, con lo que ya implícitamente se da la extensión de humanismo a la Bibliotecología. La conexión entre bibliografía y aquélla es inmediata y lógica, hasta podría decirse natural, incluso esto lo puso de manifiesto también el repertorio de C. Gesner, como lo explica Luigi Balsamo en su meritoria obra sobre la historia de la bibliografía:

Debe hacerse constar que la Bibliotheca Universalis resulta ser el tronco del que nace no sólo la moderna bibliografía sino al mismo tiempo la biblioteconomía, entendida como método y conjunto de técnicas para organizar la documentación de los libros de manera que su localización resulte fácil y rápida. En ambos sectores, en efecto, nos encontramos ante un proceso de mediación que se impone dos objetivos diferentes, para los cuales se sirve de instrumentos distintos: por un lado, del repertorio bibliográfico para proporcionar la notitia rei literariae (esto es, dar cuenta de la existencia de una determinada obra, de sus ediciones impresas y, en algunos casos, también de su contenido); por el otro, del catálogo bibliotecario para ofrecer la noti- 
Oportunidades y retos en la formación, investigación y aplicación...

tia librorum, o sea, la indicación de que, de determinadas ediciones de ciertas obras, se pueden encontrar ejemplares en un determinado lugar. Se trata de una especie de geminación de matriz única: ella confirma la globalidad de la solución metodológica dada felizmente por Gesner al problema de la información, con el que desde siempre los estudiosos, como cualquier otro lector, se han encontrado y procurado afrontar con medios más o menos adecuados; un problema que resulta bastante más complejo tras la invención de Gutemberg y que posteriormente se ha ido agravando hasta nuestros días, en relación directa tanto con el progresivo incremento de la producción tipográfica como con la reciente llegada de nuevos soportes para la documentación gráfica. ${ }^{2}$

La bibliografía de C. Gesner es, por tanto, el tronco de donde surge la Biblioteconomía; y, el subrayado es importante, entendida ésta como el conjunto de métodos y técnicas para organizar la documentación de los libros, con lo que se facilita con rapidez su localización. Al ser la bibliografía, gesneriana, el sustrato sobre el que se configura la Biblioteconomía, ésta es irrigada por la cauda humanista de aquélla: así, por ejemplo, el catálogo de las bibliotecas aún con ser un depurado instrumento técnico se encuentra aureolado por el espíritu humanista. Si la bibliografía al ser parte del sistema de comunicación social encontraba su realización en el espacio público, al dar también origen a la Biblioteconomía encauza su esencia humanista hacia el acotado ámbito de las bibliotecas. Por lo que de manera análoga a la visión renacentista en la que el hombre se encuentra ubicado en el centro del mundo moderno, como un microcosmos que refleja al macrocosmos, tal cual lo representa emblemáticamente el famoso dibujo de Leonardo da Vinci y a cuya dignidad cantó Pico della Mirandola, así puede decirse que el espacio público es el macrocosmos dentro del cual está contenido el microcosmos de las bibliotecas.

La bibliografía, al proyectar la onda expansiva del humanismo al interior de las bibliotecas por mediación de la Biblioteconomía,

2 L. Balsamo (1998), La bibliografía. Historia de una tradición, España, TREA, pp. 48-49. Las cursivas son del autor. 
signó con su impronta las funciones y actividades, las prácticas y los objetos propios de tales instituciones, así como las interacciones entre los individuos que actúan en su interior. Veamos esto último. El bibliotecario al tener los conocimientos propios del universo bibliotecario se convierte en detentador de la información y el conocimiento propios de la bibliografía; por lo que en esa posición se convierte en el mediador entre el repertorio (la colección) y el usuario. Lo que, siguiendo el código humanista de Tzvetan Todorov, hace que el bibliotecario se perfile como el yo autónomo, cuya finalidad es el tú, comprendido como el usuario. El bibliotecario al brindar al usuario una información signada por el humanismo hace de ello una celebración del tú: el usuario implícitamente es respetado al ser concebido como hombre racional capaz de recibir y brindar conocimiento y, por tanto, es un individuo libre, constructor de su destino. La información recibida por el usuario contribuye a dibujar esa libertad con la que construye ese destino de humanización. De esta forma en el microcosmos de la biblioteca se encuentra focalizada la relación entre el yo y el tú: interacción cara a cara; con lo que se realiza de manera plena y concreta la acción comunicativa que humaniza al bibliotecario y al usuario. A diferencia del espacio público donde actúa la bibliografía en que el yo y el tú, con todo y ser reales, son aún entidades genéricas, en la biblioteca adquieren nombre particular; esto es, una concreción particular y específica: el bibliotecario y el usuario, enmarcados por los ellos que conforman el espacio público.

La herencia humanista que la Biblioteconomía (entendida como conocimiento centrado en una concepción administrativa del mundo bibliotecario) recibió de la bibliografía, de ascendencia gesneriana, acabó depositándose en la Bibliotecología (entendida como ciencia cuyo objeto es la información registrada). Con lo que así queda dada la respuesta al porqué la bibliografía es la raigambre humanista de la Bibliotecología. Aunque cabe señalar que a lo largo del tránsito que va de la bibliografía a la Biblioteconomía y por último a la Bibliotecología, el aura humanista gradualmente se ha difuminado. Al grado de que la Bibliotecología suele ser entendida tanto por legos como propios, como un conocimiento de funda- 
mento técnico. Con lo que queda también de manifiesto la progresiva alienación ${ }^{3}$ de los integrantes del campo bibliotecológico respecto a sus objetos de conocimiento, lo que impide comprender su profundo y determinativo humanismo.

\section{EpÍlogo}

La construcción humanizadora que se lleva a cabo intramuros de las bibliotecas bajo la directriz de la bibliografía, con toda su aparente claridad e idealización, sin embargo se encuentra nimbada por la opacidad. En el trabajo cotidiano de los bibliotecarios lo que resulta inmediato y tangible a su conciencia es el escorzo técnico, que también por vía de la bibliografía se hace presente permanentemente. Predominio técnico que abre la puerta a la alienación en el quehacer bibliotecario. La conciencia del bibliotecario queda atrapada en y por la fascinación técnica. La facilidad que brinda la técnica se adhiere de manera natural a la rutina mecánica en el trabajo, lo que de paso ahorra la compleja laboriosidad del pensamiento. Todo lo cual acaba por nublar la intangibilidad humanista de la bibliografía, por lo que ésta termina siendo concebida y practicada como un mero listado de libros, en el que parece predominar su refinado y codificado instrumental técnico. La escapatoria ante este callejón sin salida es recuperar los pasos perdidos: reactivar el pensamiento crítico para que emprenda la arqueología de las diversas prácticas y objetos de conocimiento del campo bibliotecológico, y así sacar a la superficie el sustrato humanista, lo que con ello implica poner en su sitio a la técnica (tecnología): como un medio y no como un fin. Tal arqueología viene a ser, por consiguiente, un proceso cognoscitivo de limpieza, de depuración de los estratos que la concepción meramente técnica ha sobrepuesto a

3 En el artículo "Los bibliotecarios y la formación de lectores" ((2009), Investigación Bibliotecológica: archivonomía, bibliotecología e información, vol. 23, núm. 49, septiembre-diciembre, pp. 179-195) explico con detalle el carácter y despliegue de la alienación en la formación y actividad de los bibliotecarios. 
las prácticas y objetos de conocimiento propios del campo bibliotecológico. Lo que ha redundado en que se les conciba y asuma de manera pragmática, funcionalista y empírica: lo cual hace las veces de pantalla que obtura el proceso de la construcción teórica tanto de las prácticas como de los objetos de conocimiento. Así, también la asepsia arqueológica sería la que permitiría exhumar la identidad de la Bibliotecología: cruce de caminos entre las ciencias humanas y las ciencias sociales (prolegómeno para la construcción teórica del campo bibliotecológico, en lo que respecta primariamente a sus prácticas y objetos de conocimiento) como lo ejemplifica la raigambre humanista de la bibliografía. 



\title{
Contribución del Centro de Investigación y Desarrollo en Tecnologías del Conocimiento (CIDTEC) a la formación e investigación bibliotecológica
}

\author{
Johann Pirela Morillo \\ Universidad del Zulia, Venezuela
}

EL CIDTEC, ANTECEDENTES Y ESTRUCTURA ORGANIZATIVA

$\sqrt{A}$

1 Centro de Investigación y Desarrollo en Tecnologías del Conocimiento (CIDTEC) fue producto del esfuerzo de un conjunto de docentes e investigadores de Bibliotecología y Archivología de la Universidad del Zulia, quienes expresaron la necesidad de contar con la plataforma institucional requerida para desarrollar investigaciones científicas que aportaran soluciones a los problemas de las áreas Bibliotecológica, Archivológica y de las Ciencias de la Información, tanto en el ámbito propiamente científico-académico como en los ámbitos aplicativos e instrumentales. Plantear los antecedentes de este centro implica ubicarse en los inicios de la carrera de Bibliotecología y Archivología, debido a que siempre ha existido una relación natural entre las actividades de docencia y las de investigación, generadas en el primero Departamento y luego Escuela de Bibliotecología y Archivología de la Universidad del Zulia (EBA-LuZ).

Los antecedentes de la actividad científica en bibliotecología y ciencias de la información en la Universidad del Zulia (LUZ) se vinculan con la creación de los estudios bibliotecológicos y archivológicos como una mención de la Escuela de Letras de la Facultad de Humanidades y Educación en el año de 1962 y se afianzan con la posterior conversión en Escuela de Bibliotecología y Archivología de la Universidad del Zulia (EBA-LUZ) para el año de 1990.

Podría decirse que el proceso de desarrollo de esta labor se enmarca en tres períodos o momentos, vinculados a su vez con las 
diferentes propuestas de diseños curriculares, para cuya ejecución se consideraron concepciones que se desplazaron desde lo instrumental-técnico hasta visiones polivalentes e integrales. El primer momento abarcó desde 1962 hasta finales de la década de 1980, el segundo comprendió la década de 1990 y un tercero que va desde el 2000 hasta el 2007 (Peña, Pirela y Portillo, 2006).

En este primer momento, las concepciones del objeto de estudio estuvieron impregnadas por un marcado enfoque humanista combinado con una visión instrumental-técnica de la disciplina, que entendió la acción del profesional sólo vinculada con los aspectos técnicos y operativos de los servicios bibliotecarios y de información, lo que dio origen a la realización de labores de naturaleza aplicada que se se tradujeron en apoyo social y comunal a la organización de servicios de información y asesoramiento técnico en la organización e implantación de bibliotecas escolares y universitarias desde las denominadas "pasantías finales" con pocos indicios de trabajos concretos como producto de tales actividades, tal como lo refiere Pirela, Peña, Portillo y Peña (2002).

Los tipos de productos generados fueron manuales y otros materiales de apoyo al dictado de asignaturas, elaboración de bibliografías, índices, repertorios documentales y tesauros temáticos; de modo que el área más abordada fue la de procesos técnicos, evaluación de colecciones y obras de referencia. Se considera que la actividad investigativa durante esa etapa experimentó retrasos debido a la inexistencia de políticas, centros y líneas definidas que le imprimieron una suerte de desorientación, además de que la cultura predominante priorizaba la docencia concentrada en actividades institucionales dentro del ámbito de la propia escuela/universidad. No obstante, se asume ésta como una fase de gestación y aprendizaje que abriría paso a nuevas iniciativas.

Un segundo momento de desarrollo de la actividad científica en el área podría estarse configurando debido a los importantes cambios curriculares que impulsaron un desplazamiento de la concepción técnica relacionada únicamente con la organización de libros y otros documentos, hacia una ampliación del objeto de estudio centrado en la información en sus distintos soportes, sus servicios y 
sus procesos de gestión asociados, además de incorporar un mayor número de asignaturas metodológicas.

Según Pirela y Peña (2010), en ese momento se comenzaron a explorar nuevas temáticas como la gestión de información, los usuarios y los servicios, además de las nacientes inquietudes hacia los fenómenos impuestos por las tecnologías de la información en el contexto del sector público y en la universidad en general, lo cual significó una apertura importante en el alcance de las investigaciones hacia otros sectores.

El tercer momento se moldea con los impactos del cambio curricular de 1995, que comienzan a rendir sus frutos a partir del año 2000, momento en el que el desarrollo de la investigación registra mayores avances cuantitativos y cualitativos, producto del énfasis puesto en el binomio estudiante-profesor en el pregrado, además de experimentar un incremento en la publicación de artículos científicos y en la presentación de trabajos en eventos académicos de alcance regional, nacional e internacional, movidos por las tendencias institucionales de estímulo a la investigación a partir de premios otorgados por los vicerrectorados académicos de algunas universidades, la Comisión Nacional del Sistema para el Reconocimiento de Méritos a los Profesores de las Universidades Nacionales (CONABA) y el Programa de Promoción al investigador (PPI) impulsado por el Observatorio Nacional de Ciencia y Tecnología (ONCTI).

Pirela y Peña (2010) señalan que el nuevo interés investigativo de los profesores de la EBA-Luz los llevó a participar -por un tiempo- como coinvestigadores adscritos a grupos interdisciplinarios en centros de investigación de la universidad en especialidades como ciencias de la comunicación, ciencias económicas y administración, educación, historia, lingüística, computación, entre otras, con proyectos financiados por el Consejo de Desarrollo Científico y Humanístico de la Universidad (CONDES). La experiencia permitió que posteriormente se desarrollaran proyectos adscritos directamente a la EBA, fungiendo como centro de investigación, dada la necesidad de liderar propuestas investigativas cuyo eje central fuera la información y la documentación. 
Oportunidades y retos en la formación, investigación y aplicación...

Con la creación del Centro de Investigación y Desarrollo en Tecnologías del Conocimiento (CIDTEC), en enero de 2009, la investigación en el área de Bibliotecología, Archivología y Ciencias de la Información cuenta desde entonces con la direccionalidad necesaria, las estrategias y la estructura organizativa requerida para gestionar los procesos de creación y difusión del conocimiento científico en el área.

La estructura organizativa del CIDTEC contempla tres unidades básicas: gestión de investigación y desarrollo, formación del talento humano y gestión del conocimiento.

La unidad de gestión de investigación y desarrollo tiene la responsabilidad de coordinar la gestión administrativa de líneas, proyectos y redes de investigación científica y tecnológica, así como la de coordinar las estrategias y planes de acción de los programas adscritos a la unidad y también la de monitorear las áreas estratégicas institucionales, nacionales e internacionales que orienten las actividades de investigación y desarrollo en ciencias de la información.

La unidad de formación del talento humano es responsable de coordinar los procesos de entrenamiento, formación y actualización permanente en materia de métodos, enfoques, técnicas de investigación en ciencias de la información y áreas de interés en torno a las cuales requieran formación los clientes reales y potenciales del centro. La unidad está integrada por el Programa de Educación Continua, cuyo objetivo es fortalecer las competencias del talento humano del centro y de los clientes reales y potenciales, con visión innovadora en el área de las ciencias de la información.

La unidad de gestión del conocimiento es la instancia responsable de coordinar los procesos de sistematización, socialización y transferencia del conocimiento y las innovaciones. Está integrada por los programas de Socialización del conocimiento, Transferencia tecnológica y Medición del conocimiento. Debe coordinar las estrategias y acciones de captación, organización y socialización de la memoria científica del Centro, y definir las estrategias y acciones de los programas de socialización del conocimiento, transferencia tecnológica y de medición del conocimiento (Figura 1). 
Contribución del Centro de Investigación y Desarrollo en...

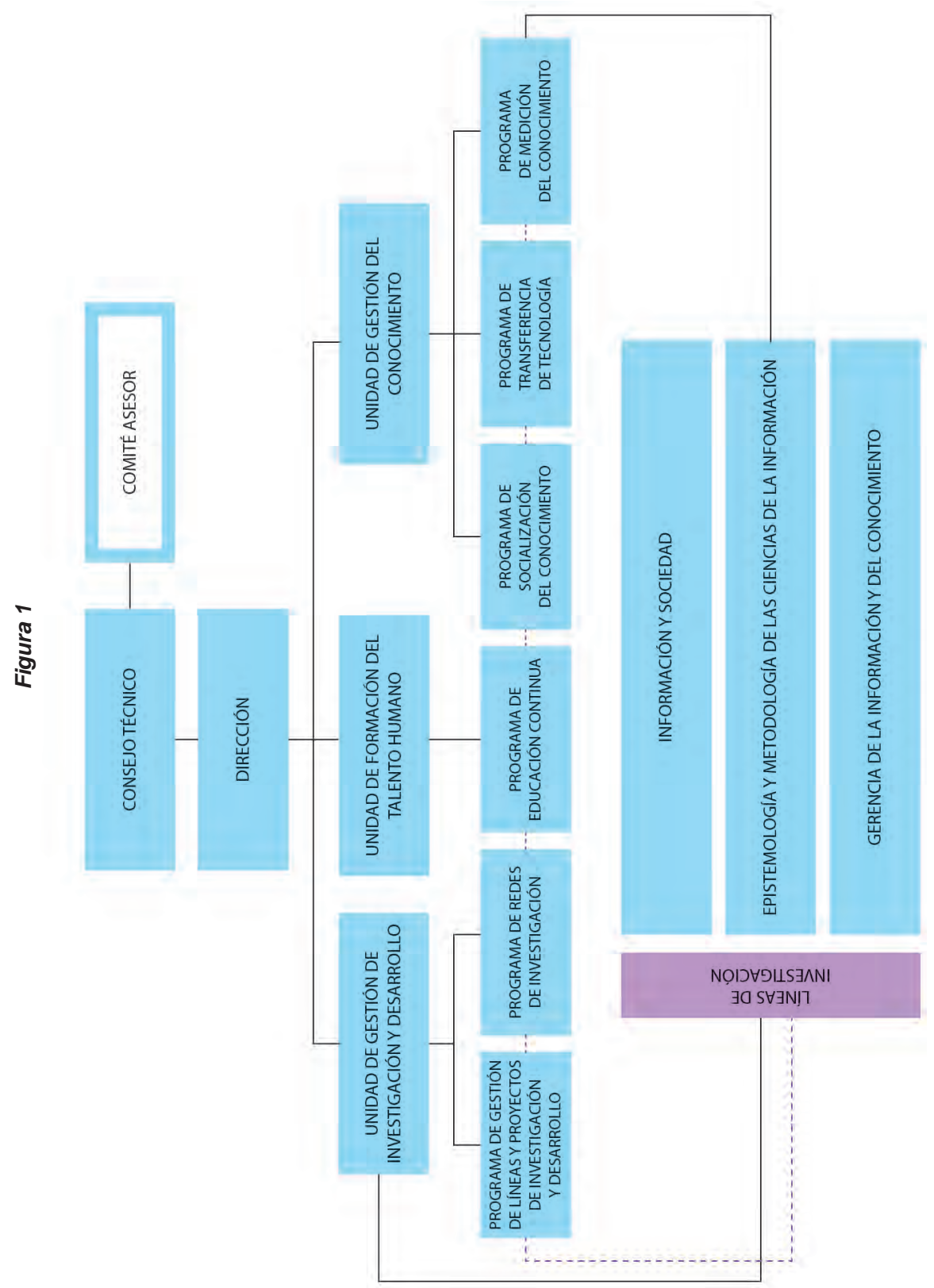




\section{CONTRIBUCIÓN A LA FORMACIÓN}

La contribución fundamental que hace el CIDTEC a la formación bibliotecológica y de ciencias de la información se concreta en el hecho de que la mayor parte de los investigadores adscritos al Centro son docentes de la Escuela de Bibliotecología y Archivología y de la Maestría en Ciencias de la Información, razón por la cual los espacios de docencia de pre y posgrado se convierten así en los ámbitos naturales para la transferencia de los conocimientos generados como producto de la investigación que se realiza. Existen casos en los cuales los estudiantes de posgrado se han incorporado a los proyectos de investigación que realizan los investigadores y ello también constituye un importante aporte a la formación en el área, desde la perspectiva investigativa.

La educación continua se asume como una de las estrategias medulares del Centro, por lo que se considera la formación del talento humano como una unidad básica del Centro. De allí que exista un Programa de formación integrado por dos ejes fundamentales: uno de formación metodológica y otro de actualización y perfeccionamiento profesional. El eje de formación metodológica contempla una serie de cursos, talleres y otras actividades de formación orientadas hacia la actualización en técnicas, métodos y enfoques de la investigación aplicados a la Bibliotecología y Ciencias de la Información. El eje de actualización y perfeccionamiento profesional incluye un portafolio de cursos, seminarios y talleres en áreas consideradas estratégicas para la formación profesional, como es el caso de la alfabetización informacional, la construcción de tesauros y ontologías, la detección de necesidades de información, las técnicas de visualización y visibilidad de la actividad científica, la metría de la información y la gestión del conocimiento, entre otras.

Cabe mencionar que al dictar estos talleres, seminarios y cursos se ha contado con la participación de docentes e investigadores de la Universidad del Zulia, universidades nacionales y de otras universidades como: la Veracruzana-México, La Habana-Cuba y Granada-España. Con la incorporación de docentes e investigadores de otras universidades iberoamericanas se pretende aplicar uno de los 
lineamientos de políticas planteados, el cual apunta hacia el establecimiento de mecanismos de cooperación nacional e internacional que fortalezcan la formación del talento de los investigadores y los profesionales del área.

\section{CONTRIBUCIÓN A LA INVESTIGACIÓN Y DESARROLLO}

DE SERVICIOS DE ASESORÍA

Las estructuras que soportan la investigación y el desarrollo del centro son sus líneas de investigación, a saber: epistemología y metodología de las ciencias de la información, información y sociedad, gerencia de la información y del conocimiento, en torno a las cuales se tienen 16 proyectos en ejecución:

Epistemología y metodología de las ciencias de la información

Los procesos de mediación como elementos integradores-unificadores del discurso epistemológico en ciencias de la información.

\section{Información y Sociedad}

Tendencias en la enseñanza y aprendizaje de las ciencias fundamentadas en tecnologías educativas.

- Desarrollo de competencias informativas para el fortalecimiento de los Consejos Comunales en el Municipio Maracaibo.

Las tecnologías de información y comunicación para organizar y representar el conocimiento. Un estudio comparativo.

* Prefiguraciones del ciberespacio en la narrativa de Jorge Luis Borges y Julio Cortázar.

Desarrollo de competencias informativas y tecnológicas en el contexto de la educación universitaria.

Tendencias y mejores prácticas de alfabetización informacional. 
Oportunidades y retos en la formación, investigación y aplicación...

* Sistema avanzado de edición LATEX y su aporte al proceso de investigación.

Evaluación de la calidad de los sitios web sobre patrimonio cultural zuliano.

Calidad de los servicios bibliotecarios de las universidades públicas del Estado Zulia.

Servicios de información para usuarios con discapacidad.

Los estudios de Bibliotecología, Archivología y Ciencias de la Información (1962-2011). 50 años de historia.

Desempeño de los docentes en las aulas virtuales de la Universidad del Zulia.

Gerencia de la información y el conocimiento

Análisis de la producción científica venezolana. Políticas e iniciativas.

El tesauro en la representación de la multimensionalidad disciplinar de la semiótica.

Definición de políticas y normas para la gestión documental en Instituciones Universitarias.

Un aspecto que debe resaltarse es que en el Centro no sólo participan investigadores de la Bibliotecología y las Ciencias de la Información, sino otros que pertenecen a otras áreas y disciplinas como es el caso de la Literatura, Ciencias de la Educación, Ciencias de la Comunicación y Semiótica, cuyos conocimientos permiten ampliar la comprensión de los problemas vinculados con la información y su impacto en los actores sociales, las organizaciones y la sociedad en general.

Como parte de la contribución a la investigación en el área, cabe mencionar la edición de tres números de Hélice: Revista Venezolana de Ciencias de la Información, en las cuales han participado investigadores de España, Brasil, Uruguay, México, Colombia, Cuba y Venezuela. Igualmente, la realización en abril de este año de las I Jornadas de Investigación del Centro y el I Simposio de Investigación 
Estudiantil sobre Organización y Representación del Conocimiento, como mecanismo que permite estimular la investigación estudiantil o una forma de ampliar la visión de la formación profesional que incorpora el desarrollo de competencias para problematizar la realidad, abordarla creativamente y generar propuestas que tiendan hacia la resolución de problemas específicos del ámbito de la información.

Por otro lado, debe resaltarse la participación de investigadores del Centro en reuniones y seminarios de investigación permanente, tal es el caso de la I Reunión de Centros e Institutos de Investigación en Bibliotecología y Ciencia de la Información de América Latina y El Caribe, que se realizó en el marco de la celebración del vigésimo quinto aniversario del Centro de Investigación en Ciencia de la Información, el cual tuvo lugar en la Universidad de Antioquia-Medellín, del 8 al 10 de septiembre de 2010. También destaca la participación de investigadores en los Seminarios permanentes del Centro Universitario de Investigaciones Bibliotecológicas (CUIB) de la Universidad Nacional Autónoma de México (unAm), de modo puntual, los Seminarios sobre Educación Bibliotecológica y el de Epistemología de la Bibliotecología y Estudios de la Información, cuyas sesiones presenciales de este año se han programado como actividades académicas previas a la realización de este XXIX Coloquio de Investigación Bibliotecológica, organizado también en el marco del XXX Aniversario del cuiB.

Además del compromiso con la formación bibliotecológica y de ciencias de la información y la investigación innovadora, el centro proyecta su acción en organizaciones públicas y privadas del sector socio-productivo mediante la prestación de servicios de asesoría. Hasta ahora se han atendido instituciones como la Alcaldía de Maracaibo, el Banco Central de Venezuela, Sub-sede Maracaibo y el Banco Occidental de Descuento. En cuanto a la Alcaldía se presentó un proyecto para conformar una Red de información parroquialcomunitaria, atendiendo a criterios de inclusión social a partir del acceso a la información y la construcción de la ciudadanía. En relación con el Banco Central de Venezuela, Sub-sede Maracaibo, se asesoró la formulación de una propuesta de servicio de biblioteca móvil (Bibliobús), concebido como mecanismo de extensión y am- 
pliación de la cobertura de las funciones del Banco, relativas a la educación económica de la población y la difusión de programas de acción social, y se incluyó también en la oferta de productos y servicios la alfabetización informacional y tecnológica, la promoción de la lectura y la difusión del patrimonio cultural del Banco. La asesoría al Banco Occidental de Descuento consistió en generar una propuesta integral para la gestión de la información documental, específicamente lo referido a los procesos de organización técnica de la documentación, la conservación del patrimonio documental y el desarrollo de sistemas de gestión documental sustentados en tecnologías de información y comunicación.

Los planes y proyectos futuros del CIDTEC apuntan hacia la consolidación de los procesos de socialización y difusión del conocimiento en las plataformas digitales, el incremento de la producción científica, la incorporación de investigadores pertenecientes a otras áreas de conocimiento para profundizar en abordajes inter y multidisciplinarios, la continuación de la participación activa de los investigadores en grupos y redes locales, regionales, nacionales e internacionales, y en el impulso a la visibilidad del conocimiento generado y trasferido a distintos ámbitos organizacionales como una forma de garantizar que la investigación se traduzca en respuestas sustantivas a problemas del entorno socio-productivo.

\section{Conclusiones}

La institucionalización de la actividad científica en Bibliotecología y Ciencias de la Información en la Universidad del Zulia es un proceso histórico que se vincula con los inicios de los estudios en el área. Dicha institucionalización pasó por diferentes momentos en los cuales las actividades científicas se desplazaron de concepciones y prácticas instrumentales, hasta la ampliación de las perspectivas y formas de entender y abordar los objetos de estudio propios de la Bibliotecología y las ciencias de la información.

La contribución del CIDTEC a la formación bibliotecológica y de las ciencias de la información se traduce en el diseño de un porta- 
folio de actividades formativas, organizadas en función de dos ejes fundamentales: uno de formación metodológica y otro de actualización y perfeccionamiento profesional. Con el eje de formación metodológica se ha pretendido dar continuidad a la actualización en tendencias teóricas y metódicas del área; y el eje de actualización y perfeccionamiento profesional ha considerado cursos, seminarios y talleres en áreas consideradas estratégicas para la formación profesional, como es el caso de la alfabetización informacional, la construcción de tesauros y ontologías, la detección de necesidades de información, las técnicas de visualización y visibilidad de la actividad científica, la metría de la información y la gestión del conocimiento, entre otras.

En cuanto a la contribución con el desarrollo de la investigación y la transferencia y la aplicación del conocimiento bibliotecológico, se han culminado con éxito 12 proyectos de investigación y se tienen en este momento 16 en ejecución, así como también la edición de números de Hélice: Revista Venezolana de Ciencias de la Información. Igualmente se han generado relaciones de cooperación académica con la comunidad bibliotecológica y de las ciencias de la información del ámbito internacional, lo que pone de manifiesto el hecho de que en tres años de funcionamiento el CIDTEC se proyecta como un Centro comprometido con la producción científica en el área y también con la formación profesional y la aplicación creativa del conocimiento científico, aportando soluciones a los problemas que se plantean a las organizaciones, referidas al manejo de la información documental como base y garantía del desarrollo.

\section{REFERENCIAS}

Peña, D., J. Pirela y L. Portillo (2006), "La investigación en la Escuela de Bibliotecología y Archivología de la Universidad del Zulia: rasgos de desarrollo y perspectivas", Extramuros, vol. 10, núm. 25, pp. 11-30.

Pirela, J. y D. Peña (2010), El Centro de Investigación y Desarrollo en Tecnologías del Conocimiento (CIDTEC): un pasado reciente $y$ 
Oportunidades y retos en la formación, investigación y aplicación...

un futuro promisorio. Ponencia presentada en la I Reunión de Centros e Institutos de Investigación en Bibliotecología y Ciencia de la Información de América Latina y El Caribe. 8 al 10 de septiembre de 2010. Universidad de Antioquia. Centro de Investigación en Ciencia de la Información. CICINF. Medellín-Colombia. Pirela, Johann, Tania Peña, Lisbeth Portillo y Dionnys Peña (2002), Pasado, presente y futuro de los estudios de bibliotecología y archivología de la Universidad del Zulia. Balance de sus dificultades, logros y proyecciones. Foro inaugural del 1er Encuentro de egresados en Bibliotecología, Archivología y Ciencias de la Información. 28 al 31 de octubre 2002. Maracaibo-Venezuela. 


\title{
El cine como documento informativo para la docencia y la investigación (con especial referencia a los estudios de derecho y cine)
}

\author{
Juan Antonio Gómez García \\ Universidad Nacional de Educación a Distancia, España
}

\begin{abstract}
La civilización democrática se salvará únicamente si hace del lenguaje de la imagen una provocación a la reflexión crítica, no una invitación a la bipnosis.
\end{abstract}

Umberto Eco ${ }^{1}$

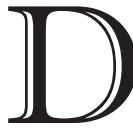

e un par de décadas a esta parte el cinematógrafo ha irrumpido con fuerza en todos los ámbitos académicos educativos (primario, secundario y superior) como una herramienta de una extraordinaria potencialidad para la educación. A nadie se le escapa que la cultura audiovisual se ha impuesto irremisiblemente en todos los órdenes de la vida actual. Las generaciones más jóvenes (principales referentes y destinatarios de todas las actividades educativas) están viviendo ya plenamente en el contexto de un mundo eminentemente audiovisual y al educador se le hace cada vez más necesario acudir a la documentación audiovisual para realizar su función más eficazmente.

Este hecho está provocando, por lo demás, que se esté desarrollando simultáneamente una interesante y fructífera reflexión general en torno al valor y a las posibilidades del cinematógrafo como elemento importante en el desempeño del trabajo del investigador, no sólo en el campo estrictamente de las investigaciones cinematográficas (teóricas, estéticas, críticas o históricas), sino también en la mayoría de las disciplinas que se denominan convencionalmente

1 Umberto Eco (1977), Apocalípticos e integrados ante la cultura de masas, Barcelona, Lumen, p. 367. 
como Ciencias Humanas y Sociales. Se está cayendo así en la cuenta de que el documento audiovisual constituye un precioso instrumento para educar y para enriquecer -e incluso articular plenamente- investigaciones en el marco científico de estas disciplinas.

La naturaleza informacional de una película constituye el factor de referencia para entender estos usos y posibilidades del cine. Desde la información contenida en un filme -de manera análoga a cualquier otro documento- puede desarrollarse formación en razón del ámbito y del interés bajo los que se mueva el usuario del mismo: bien en un plano puramente educativo, bien en un plano investigativo. Desde este punto de partida voy a reflexionar seguidamente sobre sus posibilidades, utilidades y aplicaciones en estos sentidos.

\section{EL CINE COMO DOCUMENTO INFORMATIVO}

Decimos una obviedad cuando afirmamos que el documento cinematográfico es plenamente un documento audiovisual ${ }^{2} \mathrm{y}$, como tal, en consecuencia participa de este concepto genérico y de todas sus características informativas y documentales. De ahí que lo mejor sea -en aras de expresar un sentido más amplio del objeto que aquí tratamos- plantear el concepto genérico de documento audiovisual para comprender más ajustadamente la naturaleza del documento cinematográfico.

El concepto de documentación audiovisual es un concepto ambivalente, puesto que presenta dos acepciones principales:

a) En una acepción -podríamos decir- material, la documentación audiovisual sería el conjunto de recursos o fuentes documentales de información presentadas en soporte audiovisual. El documen-

2 Ciertamente, una película silente es, en rigor, un documento solamente visual, al carecer de banda sonora incorporada al soporte documental (no olvidemos que el propio cine mudo reclamaba ya el sonido en su momento cuando se hacía acompañar por música ambiental en las salas de proyección). Sin embargo, aquí manejo un concepto de cinematógrafo en el sentido más amplio que quepa afirmarse, y focalizado sobre todo en su naturaleza eminentemente cinemático-visual, esto es, como imágenes en movimiento que se suceden entre sí según un orden determinado por el autor del filme. 


\section{El cine como documento informativo para la docencia y la...}

to audiovisual participa así de las mismas notas concernientes a los caracteres informativos y de fuente de información que caracterizan a todo documento en general, y se integra en el proceso informativo-documental genérico, propio también de todo documento; esto es, aquél que está compuesto por el emisor de la información (el autor del documento audiovisual), el canal o medio de transmisión de la información (el soporte audiovisual), el mensaje (contenido en el documento audiovisual) y el receptor o usuario de ese mensaje (contenido en el documento audiovisual).

b) En una acepción -digamos- formal, la documentación audiovisual sería, como escribe Alfonso López Yepes, “[...] la ciencia cuyo objeto es el estudio del proceso de comunicación de las fuentes audiovisuales, para la obtención de un nuevo conocimiento aplicado a la investigación y al trabajo audiovisuales". Según esta definición, prosigue el autor, "[...] la documentación audiovisual puede considerarse como una disciplina formativa, ya que prepara a investigadores y a usuarios para que conozcan su manejo y metodología, pero también como una disciplina informativa, ya que transmite al documentalista las bases de la actividad, al mismo tiempo que le dota de preparación suficiente para organizar un centro de documentación audiovisual."

De esta manera, la documentación puesta al servicio de la investigación y del trabajo audiovisuales cumple para López Yepes dos objetivos básicos:

1. Recuperar y actualizar permanentemente las fuentes y los documentos audiovisuales, mediante la realización de trabajos bibliográficos y de estudios documentales especializados, y su correspondiente automatización.

2. Establecer y mantener constantemente en funcionamiento centros de documentación automatizados para la investigación y el trabajo profesional audiovisual de profesionales audiovisuales, críticos, periodistas especializados y usuarios en general. ${ }^{3}$

3 Alfonso López Yepes (1992), Manual de Documentación audiovisual, Pamplona, EUNSA, pp. 15 ss. 


\section{Algunas notas sobre la naturaleza de}

\section{LA REALIDAD CINEMATOGRÁFICA}

Casi desde los inicios del cine los teóricos se han planteado la cuestión de la naturaleza ontológica de lo fílmico. Esto es importante traerlo a colación para comprender de antemano el modus essendi de la realidad que se nos presenta en un documento cinematográfico y, por lo tanto, ubicarnos más ajustadamente en el contexto significativo en el que se desenvuelve el contenido presentado en una película, de cara a su posible aplicación, bien para la educación y la docencia, bien para la investigación científica.

Se ha hecho ya tópica la afirmación de Ricciotto Canudo, en su famoso Manifiesto de las Siete Artes, ${ }^{4}$ que proclamaba al cine como el Séptimo Arte. Precisamente su naturaleza artística pone de manifiesto su naturaleza eminentemente subjetiva. A pesar de lo que pudiera parecer a primera vista, la imagen cinematográfica rara vez es un reflejo objetivo de lo real. Incluso en las películas documentales, o las más aparentemente impersonales o pretendidamente objetivas, la cámara va más allá de la naturaleza reproductiva de lo que capta en sus imágenes. Como se ha dicho hasta la saciedad, el simple hecho de encender la cámara y ubicarla en un lugar determinado sin más es ya adoptar un punto de vista, una mirada, en torno a aquello que se registra, y por lo tanto, la subjetividad del individuo florece irremediablemente. No digamos ya cuando además el cineasta pretende realizar una obra personal, artística, como acontece en la inmensa mayoría de los filmes al uso.

$Y$ es que la imagen cinematográfica no es totalmente realista, sino que re-crea una realidad singularizada y especificada a partir de lo real, de acuerdo con ciertas claves interpretativas que pretende explicitar su autor, tanto en el plano sensorial como en el intelectual, transformando así lo real (per se, algo esencialmente plano) en una realidad significativa, cargada de sentido, a través de un proceso de depuración y de refinamiento de lo real ejecutado

4 Vid. Joaquim Romaguera I Ramió y Homero Alsina Thevenet (1989), Textos y Manifiestos del Cine, Madrid, Cátedra, pp. 15-18. 


\section{El cine como documento informativo para la docencia y la...}

mediante los procedimientos técnicos propios del medio cinematográfico (el encuadre, la iluminación, el sonido, el montaje de las imágenes, etc.). Todo esto provoca, ante todo, emoción en el espectador, en especial porque la imagen cinematográfica tiene el sello de la subjetividad de quien la crea, lo cual acaba por trascender su presunta naturaleza objetiva, eminentemente reproductiva, con respecto a lo real.

De esta dialéctica entre objetividad y subjetividad -en última instancia, entre razón y emoción- en torno a lo presentado cinematográficamente, surge en puridad gran parte de la ambigüedad semántica que suele acompañar a toda película y que provoca que ésta -o parte de ésta- pueda ser interpretada de manera completamente diversa por distintos espectadores (e incluso por el mismo espectador, según el momento y las circunstancias en que se produzca el visionado de la misma). Esta tensión puede resolverse sintéticamente -hablo en términos extremos, puesto que caben gradaciones intermedias y matices de todo tipo- en dos sentidos: bien otorgándole total prevalencia a la subjetividad presente en la película, ubicándose el espectador en un nivel puramente estético (el cine como producto estético); bien intentando priorizar la objetividad de la imagen fílmica, situándose así el espectador en un nivel más estrictamente racional (el cine como producto intelectual).

Es en el marco de estas peculiaridades de la imagen cinematográfica donde ha de contextualizarse todo lo relativo al uso del documento cinematográfico con fines educativos y de investigación científica, y que seguidamente analizaremos por separado.

\section{LA APLICACIÓN DEL CINE A LA DOCENCIA}

En el curso de una entrevista, el gran cineasta francés Eric Rohmer dijo que el cine es pedagogía a veinticuatro imágenes por segundo. No resulta vano que Rohmer, uno de los cineastas que más han creído en el poder transformador del cinematógrafo para las personas, realizase esta hermosa afirmación, ya que simboliza en toda su magnitud el gran poder de las películas como medios para la educación. 
Ante la acusada fragmentariedad que caracteriza a la ciencia, al saber y, consiguientemente, a la educación actuales -en su obstinada búsqueda del ideal de especialización-, se ha dicho hasta la saciedad que el cine constituye un medio excelente para la formación integral de las personas. Y se dice integral para poner de manifiesto que los procesos de enseñanza-aprendizaje no se limiten sólo a los aspectos puramente racionales, sino que comprendan también los emotivos y sentimentales, con el fin último de desarrollar todas las potencialidades de los educandos en su máxima expresión. Los primeros han sido los más privilegiados en la educación tradicional, de corte casi exclusivamente literario, libresco, relegando lamentablemente a los segundos a un papel muy secundario y olvidando así la naturaleza integral del ser humano.

Resulta indispensable, pues, plantear alternativas educacionales que permitan, de alguna manera, superar esta situación. Y aquí es donde debe destacarse el papel que puede llegar a desempeñar el cinematógrafo como elemento importante en este nuevo panorama educativo. Ciertamente, el cine posee una capacidad de influencia extraordinaria en las personas, máxime en un mundo como el actual, donde lo audiovisual constituye un factor central en la vida de la gente, especialmente entre las generaciones más jóvenes, los principales protagonistas de los procesos educativos. De esta manera, el cine puede jugar un papel de gran importancia en la educación, y debe ser tenido en cuenta, en aras de lograr esa pretendida formación integral. ${ }^{5}$

Todo esto se entiende mucho mejor si se contrasta con la siguiente definición que ofrece Saturnino de la Torre de lo que denomina como aprendizaje integrado: "proceso mediante el cual vamos construyendo nuevos significados de las cosas que nos rodean $\mathrm{y}$ del mundo, al tiempo que mejoramos estructuras y habilidades

5 Vid. en este sentido: S. Ortigosa (2002), "La educación en valores a través del cine y las artes", en Revista Iberoamericana de Educación, 29, pp. 167-168; A. Corominas (1999), Modelos y medios de comunicación de masas. Propuestas educativas en educación en valores, Bilbao, Desclée De Brouwer; M. Martínez y C. Bujons (coords.) (2001), Un lugar llamado escuela. En la sociedad de la información y de la diversidad, Barcelona, Ariel. 


\section{El cine como documento informativo para la docencia y la...}

cognitivas, desarrollamos nuevas competencias, modificamos nuestras actitudes y valores, proyectando dichos cambios en la vida, las relaciones con los demás o el trabajo. Y esto en base a estímulos multisensoriales o procesos intuitivos que nos impactan y nos hacen pensar, sentir y actuar". ${ }^{6}$

En verdad, el cine, en tanto que medio de comunicación y de expresión artística, produce un efecto integrador, en tanto que una película no es otra cosa que un relato cuyo mensaje se articula a través de la conjunción de diversos lenguajes (la imagen, la palabra, la música, la interpretación, etc.), induciendo al espectador a un ejercicio íntegro de todas sus facultades mentales más allá de las lógico-deductivas o intelectuales poniendo en juego también la imaginación, las emociones y los sentimientos, y resultando así de una complejidad comunicativa tal, que hacen del cine un medio de desarrollo cognitivo-emotivo de gran calado. Todo esto si se emplea con un sentido educacional, puede llegar a ser un elemento de gran relevancia para lograr la integralidad en la formación de los educandos.

En concreto, el cine ostenta una buena cantidad de virtudes educacionales. Ante todo, es un medio de gran atractivo para recabar la atención de potenciales receptores de contenidos educativos por sus intensas capacidades para mostrar con gran eficacia todo lo que tiene que ver con los hombres y su mundo. Por el celuloide han discurrido y discurren todo tipo de historias y situaciones (reales e irreales), conflictos, emociones, sentimientos, pasiones, etc., la vida humana en toda su amplitud. Por ello, su poder para empatizar con sus receptores a través de sus contenidos es tal, que es quizás el medio de comunicación más poderoso que existe. ${ }^{7}$

$\mathrm{Y}$ es que el cine es un medio de una extraordinaria complejidad técnica y comunicativa. El sistema del lenguaje cinematográfi-

6 Saturnino de la Torre (2005), "Aprendizaje integrado y cine formativo", en Saturnino de la Torre, María Antonia Pujol y Núria Rajadell, El cine, un entorno educativo. Diez años de experiencias a través del cine, Madrid, Narcea, pp. 19-20. Sobre los fundamentos epistemológicos, psico-pedagógicos, socio-afectivos y neurocientíficos, así como los caracteres y usos de este tipo de aprendizaje, vid. pp. 18-36.

7 No en vano los regímenes totalitarios del siglo xx han tenido al cinematógrafo como el elemento adoctrinador y propagandístico central de sus programas ideológicos. 
co es una de las conjunciones más portentosas que existen desde el punto de vista de la comunicación humana a todos los niveles (sensitivo, perceptivo, intuitivo, emotivo, racional), y además su capacidad de influencia reviste un carácter tan inmediato, tan directo, que resulta un medio especialmente indicado para incidir racional y emotivamente en sus receptores con una intensidad inusual en otros medios de comunicación. ${ }^{8}$

De ahí que el cine sea un medio especialmente idóneo para realizar lo que los psicopedagogos denominan como procesos de identificación-transferencia entre lo que se muestra en las películas y lo que de ellas adoptan sus espectadores en sus comportamientos vitales en todos los órdenes (sociales, individuales, éticos, estéticos, etc.). Esta facultad del cinematógrafo se basa en su singular y extrema capacidad para provocar verosimilitud con respecto a lo que muestra, a pesar de todo el artificio que caracteriza, en general, a las películas. Éstas poseen un gran poder de persuasión para hacernos aparecer lo que nos presentan como algo verosímil, como algo verdaderamente posible, haciéndonos olvidar todo lo que tienen de artificioso, de falseamiento, y transportándonos así, como se ha dicho frecuentemente, a una situación análoga a la hipnosis. ${ }^{9}$

De esta capacidad resulta que el cine sea un excelente medio educativo para lo que se viene llamando formación en valores. En las películas aparecen valores y contravalores en el contexto de una cosmovisión determinada, y se realiza una invitación directa al espectador para que los confronte y participe en el juego propuesto, sintiéndose impelido en muchos casos a llevarlos directamente a

8 No debemos olvidar además que todo esto lo hace buscando divertir, presentándose como algo atractivo, puesto que nadie está obligado, en principio, a ver cine, y por tanto éste debe buscar atraerse al espectador, lo cual le añade un plus emotivo añadido, ya que una película ha de obtener, para funcionar, el reconocimiento y la participación afectiva de aquél.

9 Esta sofisticada relación entre realidad e ilusión como característica ontológica de lo cinematográfico ha sido indagada con gran sutileza por el gran cineasta ruso Andrei Tarkovski en su indispensable obra Esculpir en el tiempo. Reflexiones sobre el arte, la estética y la poética del cine, trad. de Enrique Banús, Madrid, Rialp, 1991. 


\section{El cine como documento informativo para la docencia y la...}

su práctica existencial. Los conflictos axiológicos que se muestran en la pantalla y se resuelven de una determinada manera abren al espectador al análisis crítico y facilitan, en último término, la modificación de actitudes y comportamientos. El más significativo ejemplo es el uso educativo del cine como estudio de casos, en virtud del cual se afronta críticamente la realidad presentada en las películas con el fin de inducir al espectador a su valoración e, incluso, a su participación (mediante su identificación o distanciamiento crítico) en ella. ${ }^{10}$

Como vengo apuntando, este proceso se lleva a cabo además apelando a la creatividad del espectador, al sobrepasar su mera percepción y al involucrar también a su memoria personal y a su imaginación. De esta manera, se implican no sólo los aspectos sensoriales, sino también los afectivos e intelectuales. En consecuencia, el cine, por su naturaleza artística, termina fomentando la creatividad del educando y constituye una formidable herramienta para educar divirtiendo.

Esta diversidad y riqueza temáticas, asociadas a su complejidad estética y formal, han llevado a afirmar la gran capacidad del cine para provocar experiencias íntimas en el espectador, hasta el punto de llegar a determinar incluso su modo de ser y actuar en la vida. ${ }^{11}$

Sin embargo aun existiendo un consenso bastante generalizado en torno a las virtudes educacionales del cinematógrafo, no debe exagerarse el uso del cine como medio educacional, puesto que el abandono total de una cultura y una educación literarias daría la razón a las visiones reacias al abandono o a la limitación de este tipo de educación. Es común oír, por ejemplo, que el cine incide negativamente en el desarrollo de la capacidad de concentración del espectador a la hora de enfrentarse con un texto escrito, pudiendo conducir a la desestructuración -incluso a la aniquilación- de su espíritu crítico, por su excesiva apelación a la emotividad del

10 Tal vez sea este uso del cine el más eficaz como medio educativo, ya que aparece aquí en toda su inmediatez y riqueza su enorme capacidad como instrumento educacional.

11 Vid. Jean Mitry (1989), Estética y psicología del cine, trad. de René Palacios More, Madrid, México, Siglo XXI. 
educando en los procesos de aprendizaje. No anda desencaminada esta opinión en cierta medida, de manera que se impone, pues, una visión equilibrada que sintetice ambas posturas, que las integre armónicamente, ya que, como vengo diciendo, la propia fuerza de los acontecimientos que nos rodean en nuestros días (la imposición irresistible de una cultura audiovisual en todos los ámbitos de la vida, sus enormes posibilidades educativas, como venimos reseñando, su gran capacidad de influencia social, etc.) así lo exige.

Ciertamente esta empresa requiere una implicación por parte de los dos polos que juegan en los procesos educativos (educando y educador) en un doble sentido. Por parte del educando es necesario que reciba una formación que lo habilite para enfrentarse al medio cinematográfico con garantías de éxito; debe ser educado para el cine o sobre el cine con el fin de que sea un buen espectador y de que pueda captar y apreciar la calidad de los contenidos fílmicos que se le presentan. Se le ha de capacitar, pues, para la correcta inteligibilidad y comprensión de los mensajes audiovisuales, por la especificidad del medio cinematográfico, en tanto presentador y transmisor de información. Por parte del educador, debe formarse a los educandos con el cine, por medio del cine con el propósito, como vengo diciendo, de contribuir a una formación integral de los mismos en un contexto tan fuertemente marcado por lo audiovisual como el que estamos viviendo. ${ }^{12}$

De esta forma el cine se revela como un espléndido medio educacional y educativo, puesto que permite encarar y llegar a la persona considerada como un todo (esto es, no concebida en segmentos o fragmentos que se discriminan y se suman como entidades discretas), como una totalidad individual y social a la que se apela en todas sus facultades psíquicas, emotivas y racionales, respetando sus diferencias al remitirlo permanentemente a su experiencia personal desde la universalidad de lo que se le presenta. Todo esto,

12 Vid. X. Úcar Martínez, R. Cortada Corominas y Ma. C. Pereira Domínguez (2003), "Los lenguajes de las artes: escenas y escenarios en educación", en T. Romañá Blay y M. Martínez Martín (eds.), Otros lenguajes en educación, Barcelona, Universidad de Barcelona, Ministerio de Ciencia y Tecnología, ICE, pp.71-116. 


\section{El cine como documento informativo para la docencia y la...}

en suma, lo hace especialmente idóneo para una formación integral de la persona.

Por estas razones se está reclamando, cada vez con mayor énfasis, la presencia del cine en las aulas y en los diseños y desarrollos curriculares de los educandos. De hecho así se está haciendo con mayor frecuencia y mayor grado de satisfacción en muchos centros educativos.

LA APLICACIÓN DEL CINE A LA INVESTIGACIÓN, LOS ESTUDIOS DE DERECHO Y CINE COMO EJEMPLO

Que el cine sea, como vengo diciendo, uno de los fenómenos culturales más relevantes del siglo xx y de lo que llevamos del xxI, es ya razón suficiente para justificar su toma en consideración como objeto de estudio por parte del investigador en el ámbito de cualquiera de las Ciencias Humanas y Sociales, desde su perspectiva científica propia.

Las posibilidades de acción en este sentido se concretan fundamentalmente en dos:

1. Considerar el documento cinematográfico como un objeto de investigación en sí mismo. En este contexto se ubicarían investigaciones propias de la Historia y la Historiografía cinematográficas, de la Estética cinematográfica, de la Crítica cinematográfica, de la Técnica cinematográfica, etc.... Éstas son líneas de investigación ampliamente cultivadas y consolidadas casi desde la invención del cinematógrafo, y que han venido configurándose como disciplinas particulares.

2. Aproximarse al documento cinematográfico en tanto que instrumento para la investigación en otras disciplinas científicas. Es el caso de los estudios de Derecho y Cine, Pedagogía y Cine, Bibliotecología y Cine, Filosofía y Cine, Historia y Cine, Política y Cine, Sociología y Cine, etc. Se trata de un acercamiento más reciente y novedoso que el anterior, y su característica fundamental es la puesta en juego de un punto de vista interdisciplinar que pone en relación al cine con la disciplina en cuestión, debido al 
singular potencial epistemológico que presenta el documento audiovisual para operar este tipo de relaciones interdisciplinares entre los distintos campos del saber.

No debemos olvidar que la interdisciplinariedad constituye hoy una de las más interesantes aproximaciones metodológicas que debería explorar el científico social en tanto que permite tematizar, de una manera eminentemente integradora, interactiva y horizontal, distintos aspectos de los campos científicos considerados, e incluso abrir (si se ejecuta bien) nuevas perspectivas, más enriquecedoras y más acordes con las nuevas demandas científicas de los tiempos actuales, a menudo tan lamentablemente tendientes a la especialización cerrada, aislada y autorreferencial. Es por ello que, tal vez, esta aproximación sea, en la actualidad, la que reviste un mayor interés para el desarrollo de investigaciones más novedosas y audaces por parte del investigador en Ciencias Humanas y Sociales.

Todo esto se ve mucho mejor si consideramos un ejemplo concreto: los Estudios de Derecho y Cine. Esta perspectiva constituye una espléndida demostración de cómo se puede usar el cinematógrafo, no sólo para enseñar Derecho, sino también para investigar en el ámbito de los estudios jurídicos, a pesar de la tradicional reticencia existente en los círculos académicos para estudiar y comprender lo jurídico fuera de lo que no sea la norma propiamente dicha. ${ }^{13}$

$13 \mathrm{Al}$ menos en el ámbito académico español cada vez son más frecuentes y exitosas estas tentativas desde que se empezaran a poner en práctica, con cierto rigor y continuidad, hace tres décadas en el ámbito anglosajón (en especial en los Estados Unidos de América). Años más tarde, a finales de los noventa, fueron acogidos en el ámbito hispano-parlante, especialmente en España, experimentando desde entonces un desarrollo en verdad asombroso. En su dimensión docente, fueron implementados en numerosos planes de estudio de las Facultades de Derecho de muchas Universidades españolas, y en su dimensión investigadora, se han creado (y se vienen creando) un apreciable número de grupos y proyectos de investigación que han dado lugar a la creación de importantes foros de discusión científica, y que han producido un gran número de publicaciones y eventos académicos.

En México comienza también a despertarse ahora una acusada sensibilidad hacia estos estudios y están empezando a recogerse los primeros frutos. Así lo demuestra la exitosa celebración de algún que otro evento científico, como por ejemplo el 


\section{El cine como documento informativo para la docencia y la...}

Los Estudios de Derecho y Cine representan un ejemplo señero de interdisciplinariedad. ${ }^{14}$ Ésta se concreta en dos perspectivas epistemológicas de desarrollo:

1. La investigación del cine como objeto del Derecho: el Derecho cinematográfico. Desde este punto de vista se considera el cine como objeto afectado por el Derecho, como un fenómeno sociocultural sobre el que existe una regulación jurídica por parte del Derecho positivo en todos sus aspectos. Así por ejemplo, aquí se trata en torno a las condiciones jurídicas para realizar, exhibir y explotar una obra cinematográfica, a las implicaciones jurídicas de su autoría, al régimen jurídico de su propiedad intelectual, de su hipotética censura, a las implicaciones jurídicas de su infraestructura industrial, etc. Estamos básicamente ante una rama del Derecho administrativo y su ejecución responde a los procedimientos metodológicos propios de la Dogmática jurídica aplicada al hecho cinematográfico en particular.

2. La investigación del tratamiento del Derecho en las películas: el Derecho en el Cine. He aquí la perspectiva epistemológica más característica y sugestiva de estos estudios. De inspiración originalmente culturalista (en los Estados Unidos se inscribieron inicialmente en el contexto de los estudios sobre Derecho y Cultura, considerando lo jurídico como resultado de procesos de

Seminario Hispano-Mexicano de Derecho y Cine, celebrado por primera vez en la primavera del año 2010 en la ciudad de Monterrey, bajo los auspicios de la Facultad de Derecho y Criminología de la Universidad Autónoma de Nuevo León. Asimismo, acaba de publicarse en México (finales de 2011) el primer libro monográfico sobre estos estudios, coordinado por el doctor Rafael Aguilera Portales y un servidor, con el título El Derecho y la Política a través del Cine y las artes narrativas (Desarrollos didácticos y curriculares) y editado en Monterrey (Nuevo León) por el CECyTE NLCAEIP. Con estas acciones se pretende que los Estudios de Derecho y Cine tengan un desarrollo y una estabilidad en el tiempo que contribuyan a implementarlos del todo y a consolidarlos en firme en el seno de los círculos académicos e investigadores del país hermano.

14 Vid. mi trabajo "Los estudios de Derecho y Cine como ámbito de investigación", en Anuario de Filosofía del Derecho, XXVI, 2010, pp. 241-246; y VV.AA. (2008), "Aproximación cinematográfico ao direito: descrición e resultados dunha experiencia docente cooperativa", en José Pernas García (coord.), O ensino do direito a través do cinema: unha perspectiva interdisciplinar, A Coruña, Universidades da Coruña, de Santiago de Compostela y de Vigo. 
naturaleza cultural), este acercamiento contempla el fenómeno jurídico en toda su extensión en los argumentos, los personajes y las historias narradas en la inmensa mayoría de las películas que tienen a lo jurídico como eje central de sus argumentos y tramas.

Esta segunda perspectiva se sustenta, como digo, sobre una consideración teórica de lo jurídico que va más allá del puro formalismo, de la simple descripción dogmático-formal y pretendidamente neutra del Derecho positivo. Responde, pues, a una concepción que comprende, además de la mencionada concepción dogmática, una dimensión más amplia y abierta del Derecho, con implicaciones filosóficas, históricas, antropológicas, sociológicas e incluso estéticas. Tal presupuesto teórico se concreta en una doble dirección:

a) Desde -lo que podríamos llamar- el cine jurídico hacia la sociedad, contemplando y analizando la influencia de este cine de temática jurídica en la conformación de los tópicos y las mentalidades jurídicas del espectador cinematográfico, con el propósito de intentar comprender su visión del Derecho.

b) Desde la sociedad hacia el cine jurídico, tratando de entender este cine como expresión de la visión social corriente del Derecho, y de las instituciones y profesiones jurídicas, a través de la actividad de los cineastas que realizan filmes de temática jurídica.

En consecuencia se trataría de considerar el Derecho en acción (Law in Action) -mediante su presentación en forma de imágenes en movimiento: Derecho en imágenes, en expresión de Benjamín Rivaya- ${ }^{15}$ buscando comprender lo jurídico en su praxis, a través de las historias narradas en las películas de temática jurídica, y de examinar en qué medida este cine jurídico es producto de una cierta manera de entender el Derecho por parte de las sociedades en que se realizan estas películas y de los concretos cineastas que las filman.

15 Benjamín Rivaya García (2010), "Algunas preguntas sobre Derecho y Cine", en Anuario de Filosofía del Derecho, XXVI, p. 228. 


\section{El cine como documento informativo para la docencia y la...}

Así pues, los Estudios de Derecho y Cine se inscriben fundamentalmente en los ámbitos académicos tradicionales de la Filosofía, la Historia, la Sociología y la Antropología jurídicas (en general de las llamadas Humanidades jurídicas), en tanto que constituyen un acercamiento a lo jurídico que incide, sobre todo y en general, en la dimensión relacional del Derecho, particularmente en sus vertientes valorativa (el Derecho visto como valor) y fáctica (eficacia del Derecho): la conformación de las mentalidades jurídicas, de la visión social del Derecho, de los juristas y de las profesiones jurídicas por parte de la (permítaseme servirme del título de la famosa película de Robert Redford) gente corriente.

En sus orígenes, los Estudios de Derecho y Cine respondieron a la necesidad concreta de que los juristas tuviesen una formación más abierta y humanística, que fuera más allá de la puramente técnico-descriptivista del ordenamiento jurídico vigente. Se trataba de que los juristas prácticos tomaran en cuenta, para la formación y conformación de su cosmovisión jurídica, los factores contextuales que rodean al Derecho, de ahí la inicial vocación pedagógica y, en cierto modo, divulgativa de lo jurídico, por parte de estos estudios. No obstante, a partir de este interés incipiente como instrumento educacional, y de manera simultánea, se ha ido desarrollando una línea de investigación general que ha hecho de estos estudios un vigoroso campo que se está abriendo paso en el seno de la ciencia jurídica de los últimos años, más acorde con una visión de lo jurídico, más abierta y flexible.

Esta línea de investigación tiene como presupuesto epistemológico fundamental la consideración de los documentos audiovisuales como textos jurídicos, lo cual los hace susceptibles específicamente para ejercer sobre ellos una hermenéutica jurídica. Partiendo de la analogía película-texto, el intérprete se ubica en un lugar común (tópos) lo suficientemente comprensivo como para ejercer una mediación (genuinamente relacional, interdisciplinar) que permita dar cuenta abierta y unitariamente de toda la riqueza hermenéutica del cine en relación con lo jurídico. Se reconoce la condición significativa -la lingüisticidad- propia de los documentos audiovisuales, al ser éstos expresiones de un lenguaje que articula y preserva su 
significatividad con independencia de cualquier circunstancia o momento concretos. Ello no implica, sin embargo, que el documento audiovisual quede condenado a una suerte de estatismo significativo, sino que su capacidad para significar se realiza permanentemente en virtud de su interpretación, de su lexis concreta, ya que la necesidad ineludible de un receptor que contemple un filme para que éste se efectúe semánticamente impone la particularización significativa de su generalidad, de su, valga la expresión, objetividad. De ahí que la textualidad del cine sea compleja, pluridimensional y comporte muchas implicaciones; y, por lo tanto, que permita múltiples posibilidades interpretativas y dé lugar a multitud de lexis particulares de muy diversa índole. Se comprende así lo cinematográfico en el seno de una tradición jurídico-cultural en incesante actualización, la cual, a su vez, lo conforma en sus interpretaciones concretas, posibilitándose su entendimiento en razón de un discurso jurídico.

En este contexto, aunque sin postergarlas del todo, las consideraciones de tipo estético sobre el cine en general, y sobre las películas concretas en particular, quedan relegadas al mero plano instrumental, en la medida en que contribuyen a una mejor inteligibilidad del contenido jurídico del objeto de interpretación. Asimismo, no puede desterrarse tampoco la toma en consideración permanente sobre otros aspectos muy relacionados, como por ejemplo la idoneidad y las capacidades del medio cinematográfico -tanto en su dimensión estética como en su condición de mass media- para transmitir ideas y mensajes significativos desde el punto de vista jurídico, la importancia que tiene el cine como medio de expresión en general y en relación con la temática jurídica en particular, etc. Estos aspectos le permiten al intérprete del filme situarse con mayor precisión en el ámbito en que ha de desarrollarse su actividad hermenéutica y crítica.

A partir de aquí, los Estudios de Derecho y Cine se ocupan de temas como, por ejemplo, el tratamiento cinematográfico del Derecho como fenómeno social, de los modelos ético-jurídicos y político-jurídicos, y de las concepciones jurídicas más importantes, de las instituciones jurídicas fundamentales (constitucionales, civiles, 
penales, mercantiles, administrativas, procesales, laborales, etc.), de los valores jurídicos, de los derechos humanos, etc. Se pretende así comprender el modo en que son referidas en el medio cinematográfico, obtener conclusiones sobre las ideas y aportaciones al respecto (pautas generales, planteamientos y respuestas más comunes a estos problemas, etc.), y considerar el fenómeno jurídico en su expresión institucional en el Derecho actual (español, mexicano, internacional público...: depende del origen de la película o grupo de películas a considerar, y del interés comprensivo del sujeto que la interpreta), en un medio de información y comunicación socialmente tan poderoso como es el cine.

En definitiva, se trata de tematizar lo jurídico a propósito de los documentos audiovisuales que se examinen. Se abre así un campo de investigación extraordinariamente rico y amplio donde caben múltiples líneas de desarrollo, la mayoría aún no realizadas. Un ámbito nuevo que apuesta, pues, por la pluralidad de perspectivas como base de la investigación y que, en consecuencia, debe ser tenido en cuenta por el investigador en Derecho. 



\title{
Las competencias en educación bibliotecológica: mitos y realidades
}

\author{
Rosa María Martínez Rider \\ Universidad Autónoma de San Luis Potosí, México
}

\section{INTRODUCCIÓN}

\begin{abstract}
$\checkmark$ e aborda el diseño por competencias en los programas edu$\longrightarrow$ cativos de la carrera de Bibliotecología como parte de la región de conocimientos de las Ciencias de la Información Documental.

Se analizan los mitos y las realidades sobre el modelo de competencias en virtud de que su establecimiento precisa de ciertos fundamentos, recursos y el posicionamiento en su desarrollo, dentro de la conceptualización de la flexibilidad educativa e institucional.
\end{abstract}

\section{Educación, COMPETENCias y Ciencias \\ DE LA INFORMACIÓN DOCUMENTAL}

La universidad pública es una institución con visión de futuros posibles, éstos pueden inclinarse a escenarios catastróficos, deseables o utópicos, para proponerle a la sociedad una educación que contribuya a erradicar las desigualdades y la incertidumbre mediante el cuidado del planeta, la convivencia multicultural, la ciudadanía democrática y el empleo para todos, aun cuando el modelo neoliberal siga avanzando y desplazando otras formas de relación social y económica. 
En todos los países o regiones del mundo se deben formar profesionales que atiendan la vocación de los sujetos en áreas particulares del conocimiento y a la vez, propicien el desarrollo social y productivo, es decir, seres humanos con calidad de vida que no sean absorbidos con la noción única de ser agentes del desarrollo mercadológico.

Las instituciones de educación superior enfrentan el reto de reflexionar y evaluar las características y oportunidades de empleo para los egresados en todas las disciplinas; innovar las prácticas pedagógicas; resolver el problema de la masificación; retomar los valores universales en la conducta y el comportamiento social ante la postmodernidad, para que la globalización no se traduzca en la carencia de posturas epistemológicas o teóricas y en la despersonalización ideológica, cultural o social; reforzar la ética desde la educación básica; y dialogar entre los distintos niveles de educación con los diferentes sectores sociales, no sólo con el mercado.

Ante este panorama surge la flexibilidad educativa, con base en los ciclos, para acortar los tiempos de formación; los créditos que incluyen el trabajo académico dentro del aula, en ambientes reales y en los virtuales; y las competencias, que posibilitan la potenciación de las capacidades del estudiante haciéndolo sentir más seguro, comprometido, colaborativo y responsable de su propio aprendizaje, lo cual se refleja en mejores desempeños.

Asimismo le brinda al estudiante un panorama muy completo sobre la realidad social, pues efectivamente, las transformaciones sociales han modificado por completo al mundo laboral en lo relativo a puestos, funciones y aun condiciones de contratación.

Respecto de las competencias profesionales, éstas se definen aquí como las capacidades que se adquieren y desarrollan para la toma de decisiones, la resolución de problemas, la entrega de resultados y la elaboración de productos en el campo profesional, con base en la integración del sistema de conocimientos, habilidades, actitudes y valores para la construcción de un mundo mejor.

Éstas han coadyuvado en un replanteamiento y reestructuración de los perfiles profesionales que implican el análisis profundo de los problemas que presenta este nuevo modelo educativo y sus po- 
sibilidades. Por ejemplo, en el cambio de profesión que se puede generar a partir de los modelos integrados por regiones del conocimiento en un área del saber o en áreas interdisciplinares.

Tales competencias promueven además la educación para la vida y facilitan la interrelación de los objetos de estudio, así como la polivalencia profesional a través de los desempeños genéricos y específicos, en el tránsito de las capacidades asociadas con las distintas actividades o tareas laborales.

El curriculum flexible (Figura 1) se diferencia del tradicional en la perspectiva desde la que se construye el plan de estudios, la pedagogía y la administración académica, las cuales se sustentan en el proyecto epistemológico y social de las disciplinas del conocimiento.

\begin{tabular}{|c|c|}
\hline \multicolumn{2}{|c|}{ FIGURA 1} \\
\hline CurRiculum tRadicional & CurRiculum flexible \\
\hline El trabajo es individual & $\begin{array}{l}\text { El trabajo es participativo, colegiado } \\
\text { e interactúa con la realidad }\end{array}$ \\
\hline $\begin{array}{l}\text { El conocimiento es fragmentado } \\
\text { y atomizado }\end{array}$ & $\begin{array}{l}\text { El conocimiento se construye con diversos } \\
\text { tipos de nociones y saberes }\end{array}$ \\
\hline $\begin{array}{l}\text { Reproducción del conocimiento } \\
\text { Pensamiento acrítico }\end{array}$ & $\begin{array}{l}\text { Facilita un pensamiento crítico a través de } \\
\text { problemas y proyectos interdisciplinares }\end{array}$ \\
\hline Las decisiones son verticales & Las decisiones son horizontales \\
\hline Se soslaya el conflicto y las crisis & $\begin{array}{l}\text { Genera menos angustia e incertidumbre } \\
\text { frente al análisis de los factores que } \\
\text { causan el conflicto }\end{array}$ \\
\hline Métodos pedagógicos tradicionales & Métodos pedagógicos innovadores \\
\hline $\begin{array}{l}\text { La formación que se imparte a través } \\
\text { de los profesores no responde a las } \\
\text { expectativas de los egresados ni al } \\
\text { mercado laboral }\end{array}$ & $\begin{array}{l}\text { Más capacidad de respuesta del egresado } \\
\text { con el desarrollo de competencias diversas }\end{array}$ \\
\hline
\end{tabular}

Fig 1. Diferencias entre el curriculum tradicional y el curriculum flexible 
El curriculum por objetivos ha sido rebasado ante las modificaciones actuales pues crea un aislamiento entre docencia e investigación; provoca el desconocimiento de la realidad social y laboral; en él la docencia es sinónimo de transmisión del conocimiento; ha creado cotos de poder entre el docente y la materia que imparte; ejerce la docencia monótona sin relación con el contexto social; y se basa en la distribución de prácticas, identidades y roles.

El curriculum flexible ha transformado las prácticas educativas y permite: interactuar con la realidad; articular el conocimiento cotidiano con el científico; brinda mayores posibilidades de facilitar un pensamiento crítico a través de problemas y proyectos interdisciplinares; produce más capacidad de respuesta del egresado con el desarrollo de competencias; provoca menos angustia e incertidumbre frente a la realidad; hace al trabajo de los diferentes actores de la educación colectivo, participativo y colegiado; por último crea una mejor respuesta hacia la sociedad y su dinámica.

La diversidad de soportes, las tecnologías de información y comunicación, y las transformaciones sociales han derivado en profundas transformaciones educativas, pedagógicas, didácticas, docentes y de aprendizaje, pues involucran preocupaciones globales de las que no se tenía mucha conciencia anteriormente, como es el cuidado de planeta y la relación del ser humano con la naturaleza que se soslayó durante la primacía del positivismo. Asimismo el comportamiento del mercado global frente a los mercados locales ha generado contrastes, contradicciones y cambios en las prácticas de las profesiones.

Las Ciencias de la Información Documental (Figura 2), como lo explicita su nombre, abarcan las disciplinas relacionadas con la gestión, el control, la conservación y la difusión del documento en diversos soportes, que se caracterizan por interactuar transversalmente entre éstas y dirigirse a la utilización de la información con fines de orientación, formación, recreación, transparencia y rendición de cuentas. 
Las competencias en educación bibliotecológica: mitos y realidades

\begin{tabular}{|c|c|c|c|}
\hline \multicolumn{4}{|c|}{ FIGURA 2} \\
\hline BIBLIOTECOLOGÍA & ARchivología & BIBLIOGRAFÍA & DocuMENTACIÓN \\
\hline $\begin{array}{l}\text { Disciplina que tiene } \\
\text { como finalidad } \\
\text { la selección, } \\
\text { adquisición, } \\
\text { difusión y } \\
\text { conservación de la } \\
\text { información. }\end{array}$ & $\begin{array}{l}\text { Disciplina que } \\
\text { tiene por objeto } \\
\text { la organización, } \\
\text { administración } \\
\text { y gestión de los } \\
\text { archivos. }\end{array}$ & $\begin{array}{l}\text { Disciplina que } \\
\text { determina el valor } \\
\text { histórico, estético y } \\
\text { cultural del libro y } \\
\text { desarrolla normas } \\
\text { y estilos para el } \\
\text { registro y control de } \\
\text { los documentos y } \\
\text { de la información. }\end{array}$ & $\begin{array}{l}\text { Disciplina que } \\
\text { organiza y difunde } \\
\text { el documento } \\
\text { a sectores } \\
\text { específicos de } \\
\text { información, con } \\
\text { el apoyo de las } \\
\text { tecnologías de } \\
\text { información y } \\
\text { comunicación. }\end{array}$ \\
\hline
\end{tabular}

Fig. 2 Las disciplinas de las Ciencias de la Información Documental. Elaboración propia en 2006

En la educación bibliotecológica se han propuesto algunos modelos de competencias como el de la Unión Europea (UE), el Mercado Común del Sur (MERCOSUR), la Special Library Association y las escuelas mexicanas en esta disciplina. En los bloques regionales de Europa y América del Sur las competencias se han analizado y determinado colectivamente. En Estados Unidos la lista es nacional para el bibliotecario especializado y en México cada escuela diseña sus competencias.

Una cantidad considerable de escuelas de Bibliotecología de América Latina ha diseñado sus planes de estudio por competencias. Otras aún discuten su inclusión curricular en función de los rasgos culturales y del empleo en los lugares de origen. Otras más, no están convencidas de sus resultados posibles o probados en instituciones similares.

A continuación se presentan algunas consideraciones sobre el desarrollo de este modelo, sus ventajas y sus dificultades en la formación superior. 
Oportunidades y retos en la formación, investigación y aplicación...

\section{COMPETENCIAS EN EDUCACIÓN BIBLIOTECOLÓGICA:}

MITOS Y REALIDADES

Todo se inicia estableciendo que las competencias no son una moda, son una política educativa internacional que responde a los cambios sociales, culturales, políticos, económicos y científicos. Tejada y Navío ${ }^{1}$ indican que se caracterizan porque la noción de competencia está asociada con el desarrollo de las capacidades, la ejecución o el desempeño; con las respuestas contextualizadas, con un enfoque plurifuncional, con los contextos profesionales cambiantes, con la polivalencia y la flexibilidad.

Aunque "las reformas y cambios curriculares continúan siendo uno de los temas que más interés suscitan en el mundo educativo," las competencias no son el único modelo educativo del siglo xxI. Hay instituciones que no cuentan con las condiciones para establecerlo, pues se requiere de infraestructura, planta de profesores formados en competencias y sobre todo una nueva actitud hacia la pedagogía y la didáctica flexible.

Las competencias educativas tampoco se basan exclusivamente en las necesidades de formación de la economía del mercado; si bien así se gestaron, ha sido un arduo trabajo para las universidades públicas transitar de los modelos tradicionales a los de competencias. Ese panorama ha cambiado porque éstas construyen sus propuestas para atender las necesidades sociales, no sólo las del mercado.

Por esta razón las competencias no presentan en todos los casos resultados eficaces e inmediatos en la educación y el aprendizaje, ni tampoco generan transformaciones holísticas en las instituciones en tanto que aquéllas son graduales y se desarrollan con diferentes

1 J. Tejada Fernández y Navío Gámez, "El desarrollo y la gestión de competencias profesionales: una mirada desde la formación”, http://www.rieoei.org/ deloslectores/1089Tejada.pdf Consulta: 24 de mayo de 2011.

2 C. Coll y E. Martín, "Vigencia del debate curricular. Aprendizajes básicos, competencias y estándares”, en Segunda Reunión del Comité Intergubernamental del Proyecto Regional de Educación para América Latina y el Caribe (PRELAC), Santiago de Chile, 11 al 13 de mayo de 2006. 
ritmos, pues están sujetas a las políticas de información, los recursos y las condiciones que facilitan su evolución.

Respecto de las realidades se ha propuesto una amplia gama de conceptos sobre las competencias, haciéndolas polisémicas y además polimórficas, pues adoptan el sentido y significado dados por las instituciones educativas y los campos laborales en los que se ponen en práctica.

En cuanto a la diversidad de conceptos, Navío ${ }^{3}$ expresa que se da una confusión terminológica al hacerse alusión a varios aspectos. Además indica que entran en juego los enfoques teóricos que posicionan la forma de percibir la competencia y la realidad profesional o laboral.

Asimismo, plantea que los modelos explicativos permiten integrar la competencia conceptualmente y orientar las acciones. Por último destaca que la delimitación de la competencia se relaciona con otros conceptos especialmente significativos en el contexto profesional, laboral y ocupacional, concretamente la capacidad y la cualificación.

Por ejemplo, desde un enfoque eficientista puede significar el uso global de capacidades para responder oportuna y de manera pertinente a las actividades y tareas laborales; y si se dirige al logro de propósitos, entonces incorpora las habilidades al conocimiento dentro de un plan de estudios, y desde una perspectiva holística se refiere a la aplicación de una formación integral en distintos contextos.

Puede centrarse en las habilidades y el cumplimiento de actividades normadas a través de la comprobación de la evidencia, o a la asesoría en el desempeño del trabajo; y desde un ángulo valorativo, a la Integración de conocimientos, habilidades y actitudes que se ejercen en el desarrollo de actividades desde contextos particulares donde se utiliza la crítica como actitud epistemológica.

Otro aspecto se refiere a la vasta tipología de competencias: básicas, genéricas, específicas, interpersonales, metodológicas, técnicas,

3 A. Navío Gámez (2005), "Propuestas conceptuales en torno a la competencia profesional”, en Revista de Educación, 337, pp. 213-234. 
individuales, sociales, ciudadanas, instrumentales, gerenciales, sistémicas, participativas, afectivas, laborales, educativas, de aprendizaje y cognitivas.

En la educación bibliotecológica se requieren desempeños asociados a las competencias científicas, metodológicas, técnicas y tecnológicas, para el desarrollo epistemológico y teórico de la disciplina y de la profesión. Las competencias ideológicas, sociales, culturales, comunicativas y jurídicas, se usan con la finalidad de incorporar sistemas bibliotecarios a los proyectos políticos, multiculturales y de diversos sectores sociales.

Mientras que las competencias mercadotécnicas se usan para generar recursos financieros en los sistemas de información que posibiliten el apoyo para el desarrollo de proyectos bibliotecarios; y las éticas y axiológicas para el desempeño íntegro y honesto de las funciones en las unidades de información al promover los valores universales.

Como ya se mencionó, las competencias ponen en juego una variedad de desempeños en la práctica profesional que tratan de resolver situaciones nuevas o imprevistas, utilizando todos los recursos disponibles.

En cuanto a los enfoques de las competencias, éstas pueden ilustrarse de acuerdo con las aportaciones de varios autores (Figura 3).

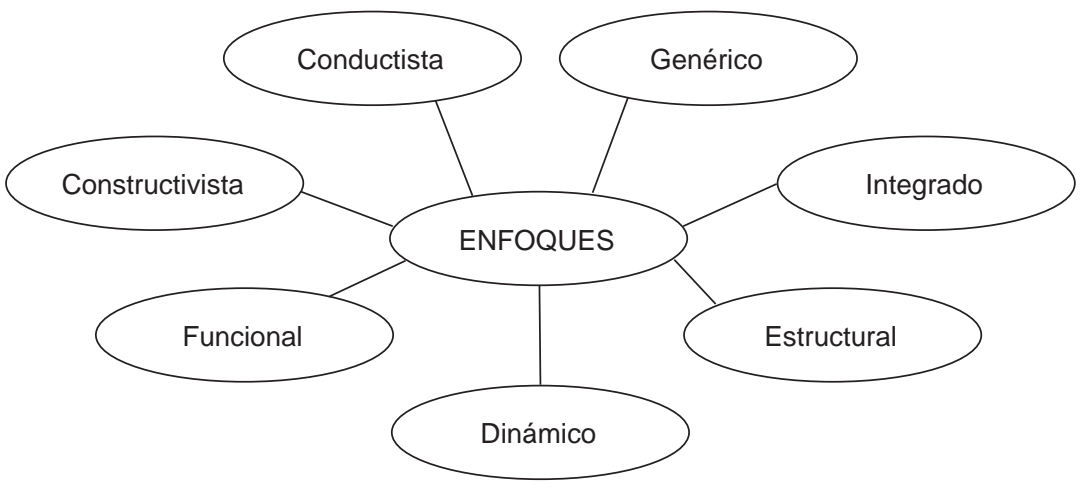

Fig. 3 Enfoques de las competencias 
Navío ${ }^{4}$ analiza los propuestos por Gonczi ${ }^{5}$ y Mertens, ${ }^{6}$ el primero los divide en Conductista, Genérico e Integrado y el segundo en Conductista, Funcional, Constructivista, Estructural y Dinámico; a estos se suman el de Cariola y Quiroz, así como el de López Camps y Leal.

La competencia conductista "parte de la persona que hace su trabajo bien, de acuerdo con los resultados esperados y define el puesto en términos de las características de dichas personas." No obstante descuida los límites de la competencia y las diferencias entre éstas. López Camps y Leal ${ }^{8}$ indican que las normas se orientan hacia resultados específicos definidos por la investigación. Mertens ${ }^{9}$ alude a la importancia de la eficiencia y la competitividad.

El enfoque genérico destaca las competencias encaminadas al desempeño universal, que pueden ser aplicadas en varios contextos. Navío ${ }^{10}$ refiere que éste es dudoso porque no hay evidencia de los aspectos subyacentes, tampoco de la transferibilidad y la exclusión del contexto.

El enfoque integrado incorpora el aspecto relacional y el sujeto dentro de un contexto. El estructural considera que la competencia se compone del conocimiento, habilidades, actitudes, comunicación y personalidad, los cuales están condicionados por los requerimientos laborales. El dinámico incluye las competencias clave de la organización y del contexto. Del funcionalista, López Camps y

4 Idem.

5 A. Gonczi (1994), "Competency based assessment in the professions in Australia”, en Assessment in education, 819, pp. 27-44.

6 I. Mertens (1996), Competencia laboral: sistemas, surgimiento y modelos, Montevideo, CINTERFOR, OIT.

7 M. L. H. Cariola y A. M. Quiroz M. (1997), "Competencias generales, competencias laborales y currículum”, en Marta Novick y María Antonia Gallart (coord.), Competitividad, redes productivas y competencias laborales, Montevideo, OIT/ CINTERFOR-RET, pp. 1-3.

8 J. López Camps e I. Leal Fernández (2000), Cómo aprender en la sociedad del conocimiento, Barcelona, Gestión, pp. 190-194.

9 Mertens, op. cit.

10 Navío Gámez, op. cit. 
Leal $^{11}$ expresan que las normas de rendimiento son desarrolladas y convenidas por el sector productivo, que es quien las fija en términos de rendimiento comparativo. Cariola y Quiroz ${ }^{12}$ establecen que en este enfoque "La empresa sólo puede funcionar con relación al mercado, la tecnología y las relaciones sociales o institucionales"13 pero el Sistema Inglés de Competencias "Nacional Vocational Qualifications", conocido como NVQ, que representa esta perspectiva, ha recibido fuertes críticas porque sólo le interesan los resultados, el fin, no así los medios ni los procesos.

El enfoque constructivista, como su nombre lo indica, "construye la competencia no sólo a partir de la función que nace del mercado, sino que [le] da igual importancia a la persona, sus objetivos y posibilidades," ${ }^{14}$ es incluyente y cuida la capacitación o formación para el desarrollo de la competencia. López y Leal ${ }^{15}$ observan que las normas son construidas desde los resultados de aprendizaje específicos, por los alcances logrados de los profesionales. Entonces, éste es el enfoque deseable, ya que se centra en un aprendizaje significativo y en el desarrollo integral del sujeto.

Una consideración adicional se refiere a que toda competencia requiere criterios de desempeño para ser evaluadas, exige el trabajo colegiado y comprometido; la flexibilidad en todos los niveles educativos; requiere el diálogo con el mercado laboral y con las necesidades sociales de información; así como un replanteamiento y reestructuración de los perfiles profesionales.

Además de la competencia y los niveles de cualificación, hay que clarificar las normas de desempeño genérico y específico, así como los tiempos y recursos en la evaluación de las evidencias, tarea responsable en la que se requieren competencias docentes; diversas estrategias didácticas; elaboración de instrumentos como las rúbricas y los portafolios para transparentar una evaluación auténtica; la revisión de los roles de la tutoría; y el análisis del mercado

11 López Camps y Leal Fernández, op. cit.

12 H. Cariola y Quiroz M., op. cit.

13 Ibid.

14 Ibid.

15 López Camps y Leal Fernández, op. cit. 
local, la estructura ocupacional y los resultados del desempeño de los egresados para su valoración y para realimentar el curriculum.

\section{ConClusiones}

La educación no consiste en identificar una serie de competencias para un plan de estudios, sino en plantear cómo van a ser desarrolladas por los estudiantes y cómo se preparará a los docentes, además de cómo se pueden medir cualitativa y cuantitativamente.

Al analizar las teorías de las competencias hay que analizar cómo han funcionado en la enseñanza, cuáles han sido sus resultados en el aprendizaje y diseñar la práctica docente de acuerdo a sus principios, contexto y contenido, así como determinar qué tan diferente o semejante es según sus cimientos y resultados.

Reflexionar en las acciones didácticas para generar un ambiente de aprendizaje que sea realmente alternativo, plural y creativo, beneficiando en primera instancia a los alumnos, que son nuestra gran responsabilidad ante la sociedad.

En Bibliotecología hay pocos estudios sobre la congruencia interna de los planes de estudios diseñados por competencias que reflejen la realidad de la formación profesional en las instituciones educativas.

También hay pocos estudios sobre los resultados de la tutoría, como acompañamiento en el trayecto escolar, como asesoría académica y sobre la inserción del estudiante en proyectos de investigación.

No hay investigaciones comparativas sobre los resultados de los egresados antes y después del diseño por competencias, que determinen, por ejemplo, cuáles son las competencias genéricas o específicas más utilizadas en el campo profesional, en qué áreas y cómo se modifica la estructura profesional. 
Oportunidades y retos en la formación, investigación y aplicación...

\section{Bibliografía}

Beckett, D. (2004), "Embodied competence and generic skill: the emergency of inferential understanding", en Educational philosophy and theory, 36(5), p. 500.

Bell, D. (1991), El advenimiento de la sociedad postindustrial, Madrid, Alianza.

Coll, C. y E. Martín, "Vigencia del debate curricular. Aprendizajes básicos, competencias y estándares”, en Segunda Reunión del Comité Intergubernamental del Proyecto Regional de Educación para América Latina y el Caribe (PRELAC), Santiago de Chile, 11 al 13 de mayo de 2006.

Contreras, José A. "Enfoque de competencias", en http://www.pdfqueen.com/administracion-un-enfoque-basado-en-competencias Consulta: el 26 de julio de 2011.

España, Universidad de Oviedo, PROYECTO EA22000055-00111188 (2005), "Modalidades de enseñanza centradas en el desarrollo de competencias", Mario de Miguel Díaz (dir.), Madrid, Ministerio de Educación y Ciencia, Universidad de Oviedo.

Gonczi, A. (1994), "Competency based assessment in the professions in Australia", en Assessment in education, 819, pp. 27-44.

H. Cariola, M. L. y A. M. Quiroz M. (1997), "Competencias generales, competencias laborales y currículum”, en Marta Novick y María Antonia Gallart (coord.), Competitividad, redes productivas y competencias laborales, Montevideo, OIT/CINTERFOR-RET, pp. 1-3.

Hyland, T., "Competence, knowledge and education", en Journal of philosophy of education, 27 (1)66, 1993.

López Camps, J. e I. Leal Fernández (2000), Cómo aprender en la sociedad del conocimiento, Barcelona, Gestión.

Mertens, I. (1996), Competencia laboral: sistemas, surgimiento y modelos, Montevideo, CINTERFOR, OIT.

Morín, E. (1999), Los siete saberes necesarios para la educación del futuro, París, UNESCO.

Muñoz Izquierdo, C. (1990), "Relaciones entre la educación superior y el sistema productivo", en Revista de la Educación Superior, 76, pp.63-91. 
Navío Gámez, A. (2005), "Propuestas conceptuales en torno a la competencia profesional”, en Revista de Educación, 337, pp. 219-222. Ruiz Iglesias, M., "La evaluación de competencias", en http://www. proyectos.dems.ipn.mx/antologia_de_competencias/aRCHIVOS\%20PDFs/LA\%20EVALUACI\%C3\%93N\%20DE\%20COMPETENCIAS.pdf Consulta: 12 de junio de 2011.

Tejada Fernández, J. y Navío Gámez, "El desarrollo y la gestión de competencias profesionales: una mirada desde la formación", en http://www.rieoei.org/deloslectores/1089Tejada.pdf Consulta: 24 de mayo de 2011. 



\title{
Fomentar la lectura a través de la publicidad en librerías y editoriales: el modelo Gandhi
}

\author{
Juan Carlos Marcos Recio \\ Universidad Complutense de Madrid, España
}

No bay lisonja, no bay fullería para un ingenio, como un libro nuevo cada día

Gracián. El Criticón.

\section{INTRODUCCIÓN}

U no de los mayores retos del ser humano, si no el mayor, es la lectura. Comprender el significado de esas letras dentro de un texto ha supuesto para la civilización su logro más considerable. A la civilización oral, en la que se iban perdiendo los mensajes, dio paso la cultura impresa y con ella la necesidad de plasmar en un soporte aquellas expresiones y sonidos que antes sólo se podían oír. Leer es un oficio, un arte, un divertimento, una manera de entender la vida, una forma de presentar la realidad. Ya el propio Cervantes, al reflejar la desmedida afición de su héroe por la lectura de los libros de caballerías decía: "[...] se le pasaban las noches leyendo de claro en claro, y los días de turbio en turbio".

La lectura requiere de un ejercicio físico, sobre todo si se compara con los modernos medios de comunicación. No todos están dispuestos a esforzarse por leer; hay que encontrar un libro que sea el "culpable" de las futuras lecturas. Pero no todos lo encuentran. Algunos, ni siquiera lo intentan. Pero como cultura y educación van de la mano y como es responsabilidad de un Estado la educación de sus miembros, la primera propuesta que se hace al ser humano cuando entra en la escuela es la lectura. Juntar letras para que tengan un valor, unirlas para entender, copiarlas para recordarlas. 
En fin, verlas para escribirlas y para que otros puedan leer luego lo antes aprendido.

Es propósito de este trabajo presentar datos sobre la población lectora, centrados en España y México, con el fin de analizar el esfuerzo que aún queda para sostener que las sociedades de esos países están a un gran nivel de lectura. Además, frente al esfuerzo en fomento de lectura por parte de los estados, las fundaciones, las instituciones educativas y los círculos y clubes de lectura, hay empresas que también lo hacen. Se trata de evaluar la publicidad y los recursos de mercadotecnia que emplea la librería Gandhi, con el fin de calar en la sociedad mexicana para que lea y, también, para que compre sus libros.

\section{LA LECTURA COMO INDICADOR DE LA SOCIEDAD}

Con cierta frecuencia se utiliza la economía como motor de un país, como argumento de peso para considerar que es una potencia y se olvida que para llegar a esos niveles se requiere antes un excelente nivel educativo. Aquellas sociedades que invierten en educación, que son emprendedoras, que miran hacia el futuro con distancia, que quieren mejorar en todos los ámbitos, son las que terminan convirtiéndose en líderes. En todas ellas ha primado en algún momento de su gestión la educación.

Y no hay educación sin lectura. Sin libros no hay avances. Como tampoco sin docentes que animen y fomenten la lectura en la escuela, la comprensión de las ideas que se plasman en los libros de educación secundaria y la reflexión y crítica que han de plantear los estudiantes universitarios a cada texto propuesto por su maestro.

El triángulo perfecto que acompaña a educación y cultura es el libro. Si se comparan las sociedades de hace dos o tres siglos con las actuales, en las primeras el poder detentaba los privilegios de la lectura y no quería una sociedad más formada para seguir controlándola; con la de ahora, el porcentaje de lectores indica que cuanto más lee una sociedad más libre es; cuanto más lee, más control tiene sobre sí misma; cuanto más lee, más fácil es su pro- 
greso y cuanto más lee, más difícil es que le impongan otras ideas. Se lee para ser libre, pero también para colaborar con una sociedad más justa. Sin embargo, cuando se han producido grandes guerras, cuando al ser humano le ha faltado la razón, si hubiera acudido antes a los libros quizás no habría avanzado hacia la barbarie.

En definitiva una sociedad lectora es aquella capaz de sentir y hacer sentir al ser humano como parte del universo y desarrollar actividades para mejorar y progresar. Los libros forman, educan, entretienen, distraen, abren y cierran puertas o en palabras del gran poeta nicaragüense Rubén Darío: "El libro es fuerza, es valor/es poder, es alimento/antorcha del pensamiento/y manantial del amor".

\section{La lucha por la alfabetización}

El siglo xx ha sido el de mayor lucha por la alfabetización, al menos en lo que se refiere a los gobiernos que han considerado una necesidad y una obligación hacer que todos sus ciudadanos sepan leer; especialmente a raíz de la creación de la Organización de las Naciones Unidas para la Educación, la Ciencia y la Cultura (Unesco). Ésta se fundó el 16 de noviembre de 1945 con el objetivo de contribuir a la paz y a la seguridad en el mundo mediante la educación, la ciencia, la cultura y las comunicaciones. Uno de sus objetivos más importantes ha sido, pues, desde entonces la alfabetización. Como se recoge entre sus objetivos:

La Unesco tiene vocación pacifista, y entre varias cosas se orienta muy particularmente a apoyar la alfabetización. En la educación, este organismo le asigna prioridad al logro de la educación elemental adaptada a las necesidades actuales. Colabora con la formación de docentes, planificadores familiares y vivienda, administradores educacionales y alienta la construcción de escuelas y la dotación de equipo necesario para su funcionamiento (Unesco, 2010).

Es, pues, una necesidad para este organismo fomentar desde las escuelas la lectura, la educación más elemental y la ayuda para crear 
Oportunidades y retos en la formación, investigación y aplicación...

equipos humanos y técnicos que a través de la lectura lleguen a hacer una sociedad más justa, sobre todo en países con escasos recursos.

\section{La alfabetización como referente para la lectura}

El esfuerzo considerable porque la población en su totalidad supiera leer y escribir se produjo en el siglo pasado. Nunca antes una nación podía haber señalado que su población sabía leer y escribir. Y ni siquiera en los países más avanzados se puede decir que todos sean alfabetos, ya que existe en ellos un pequeño número de personas adultas que no han tenido ocasión de aprender.

El primer paso para la lectura es la erradicación del analfabetismo. Se puede definir éste como la carencia de lectura y escritura del ser humano. Por el contrario, es alfabeto o está alfabetizado aquel que tiene la capacidad de leer y escribir una frase sencilla, según unESCO. En su Informe del seguimiento de la Educación para todos en el Mundo 2007, se recogen algunos términos que definen quién es y quién no es alfabeto. Con carácter general se recoge en dicho informe: "Se entiende por población alfabetizada todas las personas que son capaces de leer y escribir un texto relativo a la vida cotidiana, sea cual sea la lengua utilizada. Se considera analfabetas a las restantes personas, comprendidas las que sólo saben leer", (Unesco, 2007: 234). Esta misma institución señala que una nación alcanza la alfabetización cuando más del $90 \%$ de su población adulta está alfabetizada. Sin embargo este concepto es diferente dependiendo de los países. Así, en Tailandia: "Se considera alfabetizadas a las personas de 5 años o más que son capaces de leer y escribir, comprendiendo los enunciados simples en cualquier lengua. Se registra como analfabeta a toda persona que sabe leer, pero no sabe escribir", (Unesco, 2007: 243).

Por su parte en el mismo informe se señala que en México: "A las personas alfabetizadas se las define en función de su capacidad para leer y escribir un mensaje, entendido éste como la presentación sucinta y sencilla de un hecho de la vida diaria", (Unesco, 2007: 241). Para hallar esta definición se tomó como referente la 
Encuesta Nacional sobre los Ingresos y Gastos de los Hogares en 2004. En España se considera una persona analfabeta a aquella que no sabe ni leer ni escribir.

\section{España, datos para su erradicación}

La referencia para conocer el grado de analfabetismo y, por tanto, las personas que no saben leer en España, es el Instituto Nacional de Estadística (INE) el cual señala que de forma general aquél se ha reducido a la mitad en los últimos 25 años. En un informe publicado en Información con motivo del XXV Aniversario de la Constitución se señala: La población 'sin estudios' ha disminuido en un $10.3 \%$, porcentaje que es de un $55.7 \%$ en la población analfabeta. Aun así, más de un millón de españoles son analfabetos, en su mayoría personas mayores de 55 años, en concreto un $82 \%$. En la población que no ha logrado concluir sus estudios primarios, el porcentaje de mayores de 55 años supone el 81.4\%”. Unos años después, en 2005 había un $2.15 \%$ de analfabetos y en 2007, según el INE aún había 858000 personas analfabetas en toda España. La tasa de analfabetismo se fue reduciendo durante la década de 1990 y principios del nuevo siglo (en 1991 había un 4.90\% de analfabetos mientras que en 2005 había casi la mitad, un $2.15 \%$ ), pero ha vivido un ligero repunte en los dos últimos años, hasta situarse en el $2.3 \%$ en 2007 . Un año después otro estudio del INE señalaba que la cifra de residentes en el país mayores de 16 años que no saben leer ni escribir asciende a 915 300, el 2.4\% de la población.

Así, la tendencia descendente de las últimas dos décadas se invierte. El periódico español Público lo reflejaba en una información: "El colectivo de analfabetos ha pasado de 783800 en 2005, a 830100 en 2006, y a 841700 en 2007. La media de los tres primeros trimestres de 2008 es de 910 233", (Hualde, 2008). En este sentido algunos expertos señalan que ese aumento se debe al crecimiento de inmigrantes que no sabe leer ni escribir (español).

Cuando se comparan las Comunidades Autónomas (Gráfico 1), la peor cifra la representa Extremadura, donde un 5\% de la pobla- 
Oportunidades y retos en la formación, investigación y aplicación...

ción no sabe leer ni escribir. Le siguen Andalucía (4.3\%), Castilla-La Mancha (4\%) y Murcia (3.8\%). Por el contrario, La Rioja, con un $0.4 \%$, es la comunidad con una tasa menor de analfabetismo, seguida de Cantabria y Navarra (0.5\%) y del País Vasco (0.7\%).

\section{Radiografía del analfabetismo en España}

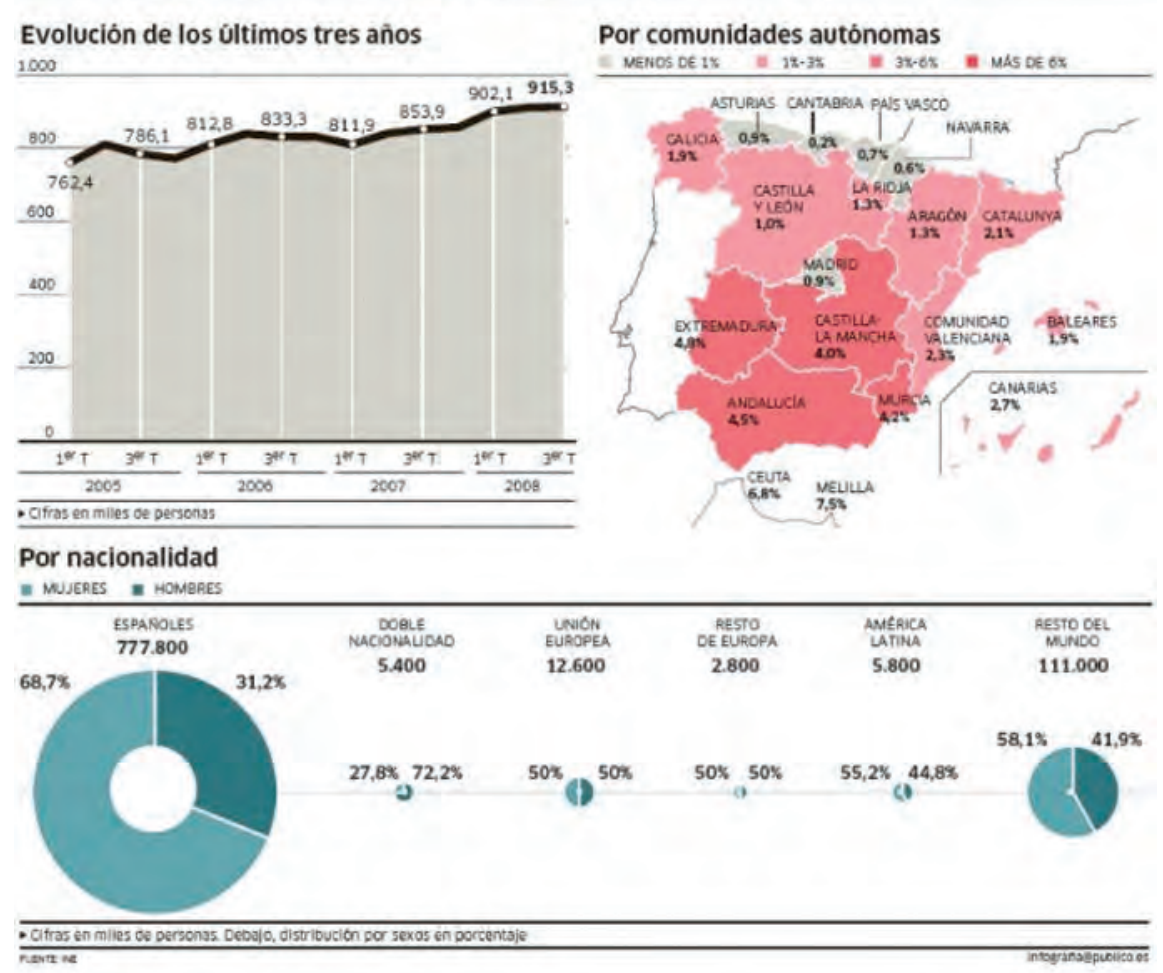

Gráfico 1. El analfabetismo por Comunidades Autónomas. Fuente: Público

En definitiva, España tiene aún un corto camino pero intenso para erradicar el analfabetismo. Es una tarea del Gobierno y una responsabilidad de todos los ciudadanos, que aquellos que no tuvieron oportunidad o que no quisieron deben entrar ahora a formar parte del club de lectores y escritores. 


\section{México, datos para la esperanza}

El homólogo al INE español es en México el Instituto Nacional de Estadística, Geografía e Informática (INEGI) que a través de diferentes estudios evalúa la población mexicana en varios temas. En el caso aquí referido se toman como propuesta los datos que en su día, en las vísperas del Día Internacional de la Alfabetización, facilitó este organismo.

Además se referencian datos del XII Censo de Población y Vivienda 2000, en el que se señala que de la población de 15 y más años, 7 de cada 100 hombres y 11 de cada 100 mujeres son analfabetas. Así, de los 62.8 millones de habitantes de esa edad, alrededor de 56.8 millones son analfabetas. Y el crecimiento aumenta con la edad. Así, alrededor de 294000 personas de 15 a 19 años son analfabetas, cifra que se eleva a un millón y medio con aquellos de más de 65 años.

A pesar de que la educación básica es obligatoria, de los 19.7 millones de niños de entre 6 y 14 años, 2.4 millones no saben leer ni escribir y los hombres superan a las mujeres en 123443 , según el INEgi. Por último, en el año 2000 este mismo rango de población asistía a la escuela en un $91.3 \%$ frente al $85.5 \%$ de 1990.

Por el contrario los datos actuales son esperanzadores. Así en el año 2010, el INEGI indica que para una población de más de 15 años, en un total de 78423 336, el $92.4 \%$ son alfabetos, de los cuales el $93.73 \%$ son hombres y el $91.1 \%$ mujeres.

Esta mejoría es la base de este trabajo, ya que cuanto mayor sea el número de lectores, más libros habrá, más editoriales se crearán y más formada estará la sociedad mexicana. El reto de todo docente y también el de los bibliotecarios es animar a la lectura. El Estado, las universidades, los centros de investigación son conscientes de estas necesidades e incluyen en todos sus programas docentes a la lectura como apoyo para cualquier formación. El otro reto es la industria privada de las editoriales, que abren librerías para obtener beneficios, pero también para mejorar la educación de un país. Ése es uno de los retos de Gandhi. 


\section{Publicidad Para inCREMENTAR las Ventas y los LeCtOReS}

Cualquier actividad empresarial, y el mundo de las editoriales lo es, requiere de elementos que le den a conocer el producto a los consumidores. Durante siglos, el "boca a boca" fue la mejor manera de hacer publicidad, sin embargo la llegada de los medios de comunicación masivos cambió el panorama y mucho más, aun con la presencia de Internet y las redes sociales, con las que el mundo editorial es uno de los beneficiados.

¿Es necesaria la publicidad para vender libros, discos, música, videos, etc.? ¿Quién debe hacer campañas de publicidad para vender cultura? ¿Las campañas de fomento de la lectura de los gobiernos sirven para vender más libros? Pues sí, en la librería Gandhi lo tienen claro (Figura 1). Sus campañas publicitarias también se plantean para que la gente lea y si el lector no se acerca a la lectura, a la tienda de libros, es ésta la que debe "tentarlo" para que entre, revise las páginas, mire la portada, lea un rato y compre. Hay que buscar al lector y hacerlo partícipe del proceso de lectura.

\section{Sí. Soy parte de una estrategia publicitaria para hacerte leer.}

\section{gandhi.}

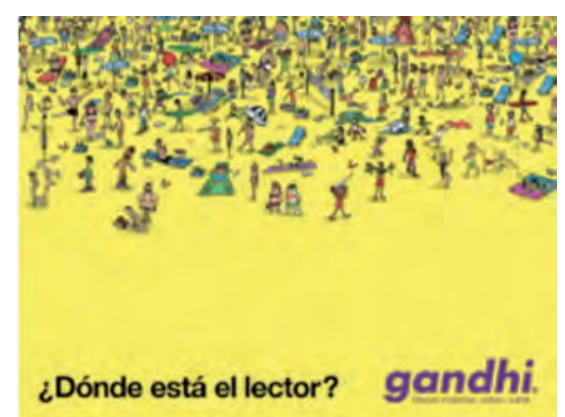

Figura 1. Estrategias publicitarias para encontrar lectores.

Conviene precisar antes, qué se entiende por publicidad y luego responder a cada una de esas cuestiones. El profesor González Martín al definir el concepto publicidad considera también los principales elementos de ésta al referirse al producto (libro), y su intención de presentarlo para ser consumido: "La publicidad es un medio de difusión de ideas ajenas (también un libro) y una técnica 
de persuasión orientada a dar a conocer de forma positiva, laudatoria y plena la existencia de productos y servicios, procurando suscitar su consumo”, (González Martín, 1996: 8). Así pues, la misión de una editorial es hacer libros para venderlos, procurando incitar al consumo que no es otro que su compra y lectura. Al resto de interrogantes respondió Alberto Achar, gerente de Mercadotecnia de Gandhi, quien contestó a una entrevista que se aplicará a otros responsables de mercadotecnia de editoriales españolas. En el caso de Gandhi Achar indicó que sí hacen campañas de publicidad, unas dos por año y a veces con carácter trimestral. Esas campañas están dirigidas a un objetivo muy específico:

De 18 a 55 años de edad; 54.80\% hombres, 45.20\% mujeres; nivel socioeconómico abc+ (medio, medio alto, alto); $17.10 \%$ intelectuales, filósofos, analistas, escritores, pensadores, líderes de opinión, gente que tiene como parte fundamental de su vida la lectura, la cultura y el arte (lectores altos, de 5 libros en adelante en un período de 6 meses); $53.30 \%$ personas que buscan pasatiempos, que leen de vez en cuando y les gusta tomarse un café, ver libros, y discos; que buscan nuevas experiencias de compra, regalan muchos libros y a quienes les gusta el arte y la cultura (lectores medios: hasta de 4 libros en 6 meses) y $29.60 \%$ estudiantes y profesionales que buscan libros por necesidades escolares o laborales (lectores bajos, un libro en un período de 6 meses) (Encuesta Responsable Mercadotecnia).

El gerente de Mercadotecnia de Gandhi considera que las campañas de publicidad institucional sí redundan en un mayor número de ventas.

En definitiva, la buena publicidad, incluidas las campañas estatales, favorecen la lectura entre los consumidores -léase ciudadanos lectores- y mejoran el nivel cultural y educativo de una sociedad. Además, se ha comprobado que cuando se planifican este tipo de campañas aumenta el número de lectores. (Figura 2). 


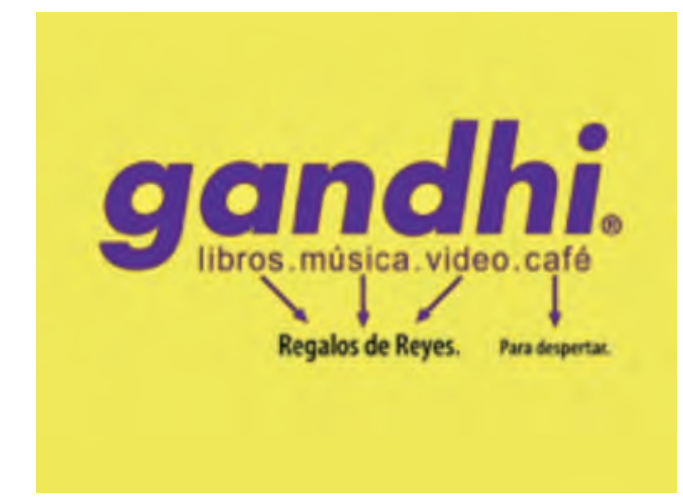

Figura 2. Logotipo de Gandhi usado en tiempo de regalo de Reyes

\section{GANDHI: UNA FORMA DE ACERCARSE A LOS LECTORES}

Gandhi, una de las grandes librerías mexicanas, aunque vende también música y videos, se ha convertido en los últimos tiempos en un referente en lo que se refiere a la lectura y en multitud de actividades en torno a ella. Lecturas, encuentros, jornadas, cuentacuentos, presentaciones de libros, listas de novedades, y algunas acciones que en ocasiones se hacen en las bibliotecas encuentran en esta "megalibrería" un campo de acción para todo tipo de públicos. Lo que empezó como una idea muy particular ya se está poniendo en práctica en otros países. Y una parte del éxito lo tiene la publicidad y las acciones de comunicación publicitarias, pero antes los orígenes de esta librería.

A mediados del año 1971 vio la luz la primera de estas librerías en un local de $150 \mathrm{~m}^{2}$ ubicado en Miguel Ángel de Quevedo 128, al sur de la ciudad de México. Un edificio pequeño pero con cafetería y espacio para desarrollar actividades culturales (cine, teatro, música, presentaciones de libros, etc.) y que luego éstas se convirtieron en una de sus características principales. En la actualidad, según Alberto Achar, cuenta con 25 sucursales que dan trabajo a más de 550 personas, y ha pasado a ser la cadena más importante de librerías profesionales de México y seguramente una de las más importantes de América Latina. Este recinto es un lugar de infor- 
mación, consulta y entretenimiento para profesores, estudiantes, lectores, profesionales e intelectuales. Una manera de acercarse a la cultura y disfrutar de ella dentro de la tienda. Pero no sólo hay libros, también se puede encontrar música y videos tanto nacionales como internacionales.

Espectaculares, separadores, postales y bolsas

Desde sus orígenes Gandhi tenía claro que además de vender libros quería desarrollar actividades culturales. En una ciudad tan grande como el Distrito Federal se requería anunciar estas actividades para que el público asistiera. Por ello desde el principio la publicidad ha estado presente en la gestión de la librería. No es una publicidad que requiera grandes inversiones, pero sí regularidad. En la Figura 3, se observa un pase de abordar utilizado como publicidad que incluye un referente importante: "Viaje a La Mancha, viaje para conocer a Cervantes". Hay que advertir que el separador lleva publicidad por las dos caras.
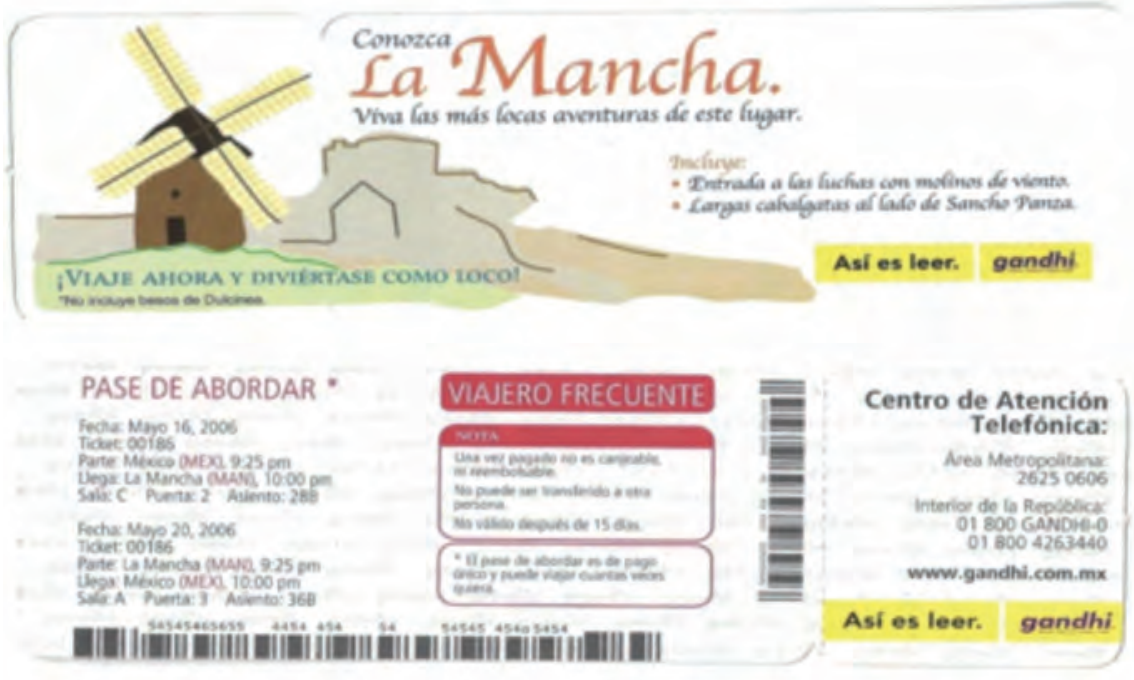

Figura 3. Primeros separadores utilizados por la librería 
Una estrategia publicitaria puede plantearse de diferentes formas y utilizar varios tipos de medios para su difusión. En el caso de Gandhi, el mejor planteamiento es el impreso. Dispone de videos que están en las redes sociales con muchos seguidores y que aparecen en los medios de comunicación; pero lo importante es el valor que se le da a cada acción publicitaria. Sirva como ejemplo que el lector o cualquier usuario puede acceder a toda la publicidad desde hace más de una década en su página web. El color amarillo característico con letras negras y el logotipo morado no siempre se ha utilizado. En ocasiones, ese amarillo se transforma en rojo e, incluso, en blanco, como se aprecia en la Figura 3.

En este caso se analizarán algunas de las estrategias más comunes y efectivas de Gandhi, con mayor impacto y recuerdo en sus usuarios. Sobre todo, espectaculares, separadores, postales y bolsas. Los primeros son anuncios o carteleras en grandes dimensiones. Hay de varios tipos, bajitos, altos, monopolares (por lo general un tubo) céntricos o excéntricos, adosados en edificios, en azoteas, etc., y con unas medidas de más de $50 \mathrm{~m}^{2}$. Esta forma de hacer publicidad es la que más usa Gandhi, con mensajes claros, directos, con un toque de humor y con un interés por conseguir lectores, ya que cuantos más haya, más posibilidades de vender libros tiene la empresa.

Los espectaculares utilizan expresiones conocidas o inventadas, con mensajes directos, con un cuidado especial a la hora de seleccionar el texto y con una idea muy clara: Leer por encima de todo, incluso en las redes sociales donde el lector pasa cada vez más tiempo y menos dedicado a la lectura, (Figura 4). Se pueden contemplar más de 200 espectaculares en el sitio de Facebook que tiene la librería y también en su web, en la sección de publicidad.

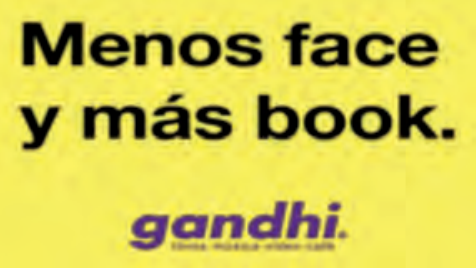

Para seguir leyendo, inserte una moneda aquí:

Figura 4. El lector suma tiempo en las redes sociales pero no frente a los libros. 
Los separadores son un tipo de publicidad que suele utilizar la mayoría de las editoriales para promocionar libros nuevos, captar lectores y dar a conocer algún nuevo tema dentro de la editorial. Los separadores suelen tener unas medidas parecidas y a los lectores les vienen bien porque sirven para marcar el final de su lectura. En Gandhi se han confeccionado una gran cantidad de ellos y suelen presentarse impresos en una cara (Figura 5) o en las dos (Figura 0), y tratan de llamar la atención sobre las bondades que aporta la lectura, pero también es norma en la publicidad de Gandhi destacar aquellos aspectos que se pierde la persona que no lee. Si no lees te irás al infierno o si no lees no serás listo, ya que de esa forma se incita al no lector a pasarse al mundo de la lectura y a comprar libros.

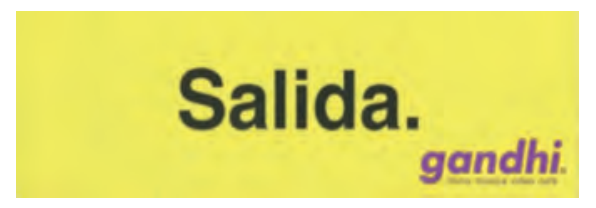

\section{Meta.}

gandhi.
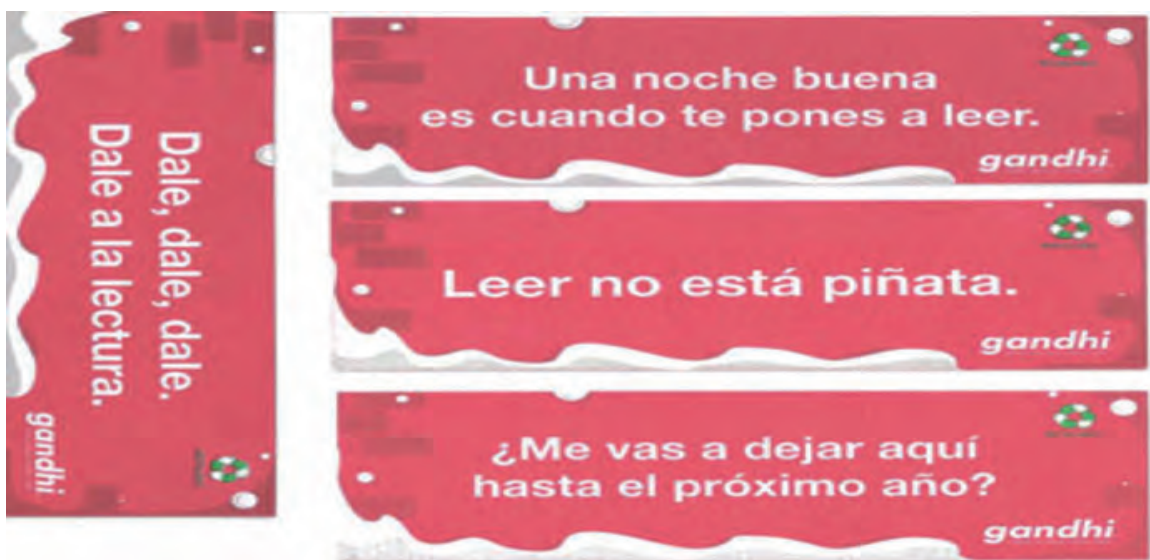

Figuras 5 y 6 . Algunos ejemplos de separadores o marcadores de lectura.

Una de las épocas importantes de venta, también para las editoriales, es la Navidad, un tiempo en el que la gente regala libros, música, videos y por eso Gandhi ha elaborado una publicidad es- 
Oportunidades y retos en la formación, investigación y aplicación...

pecífica de esa época, tanto en espectaculares como en separadores, (Figuras 7 y 8 ).
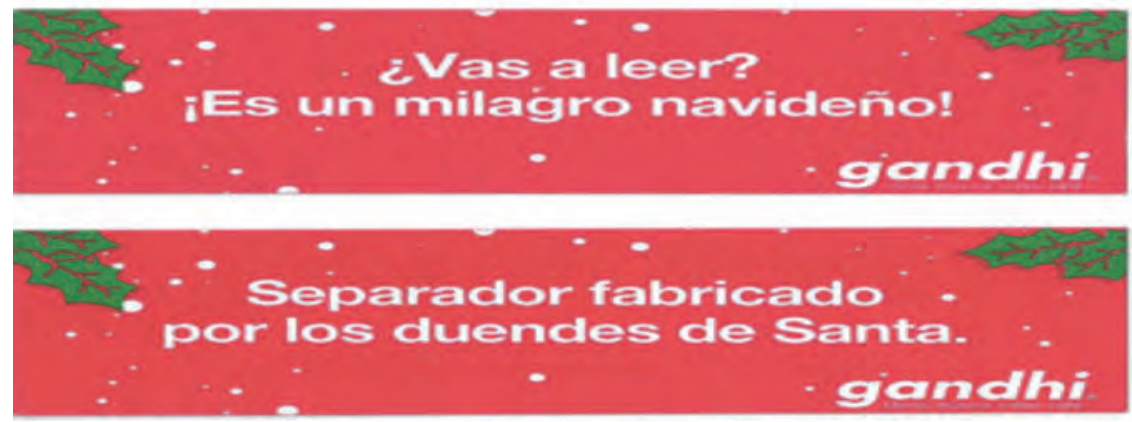

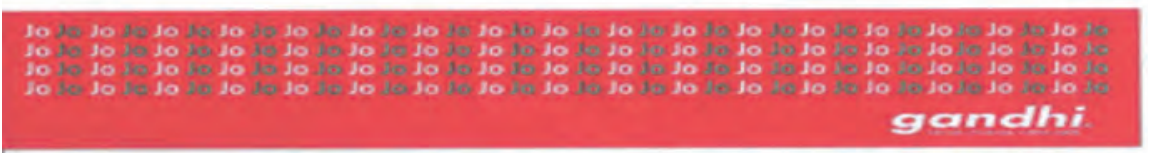
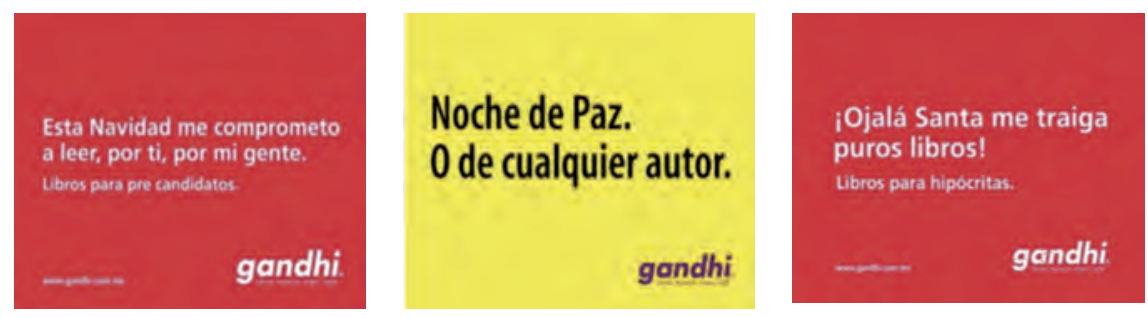

Figuras 7 y 8 . En Navidades se regalan libros y se anima a la lectura.

Por último las postales y bolsas son otro soporte que se emplea en publicidad, en este caso compartiendo algunos recursos con los anteriores soportes. Se trata de crear imágenes que identifiquen a autores consagrados en la literatura, en el primer caso y, en el segundo, mensajes directos para el uso de las bolsas: "No voy. Me llevan", "Soy bien fácil, me voy con cualquiera" o "Haz como yo: llénate de libros".

Es preciso señalar en este apartado que la publicidad ha creado secciones que apuntalan algún aspecto significativo en el que se produce una serie de espectaculares con el mismo mensaje, pero 
con distintos protagonistas; en algún caso, son gente de la calle, gente próxima para que la publicidad sea más efectiva; por ejemplo: "Libros para..." (Figura 9); "Qué horror. Mejor lee...", "Ya leíste el..." (Figura 10), "Así es leer..." (Figura 11). También se tiene en cuenta el tiempo que los mexicanos le dedican a la televisión y a las redes sociales, ya que se considera que ese tiempo no es de lectura y por eso se quiere convertir el canal de televisión en canal de lectura. Otro aspecto importante en la publicidad es la apertura de una nueva tienda. Cada vez que se abre se emplean recursos como: "Ahora en... (con el nombre de la ciudad)", (Figura 11), o "Jalisco también lee". En definitiva, publicidad impresa con mensajes llamativos, irónicos y la mayoría con un fino toque de humor.
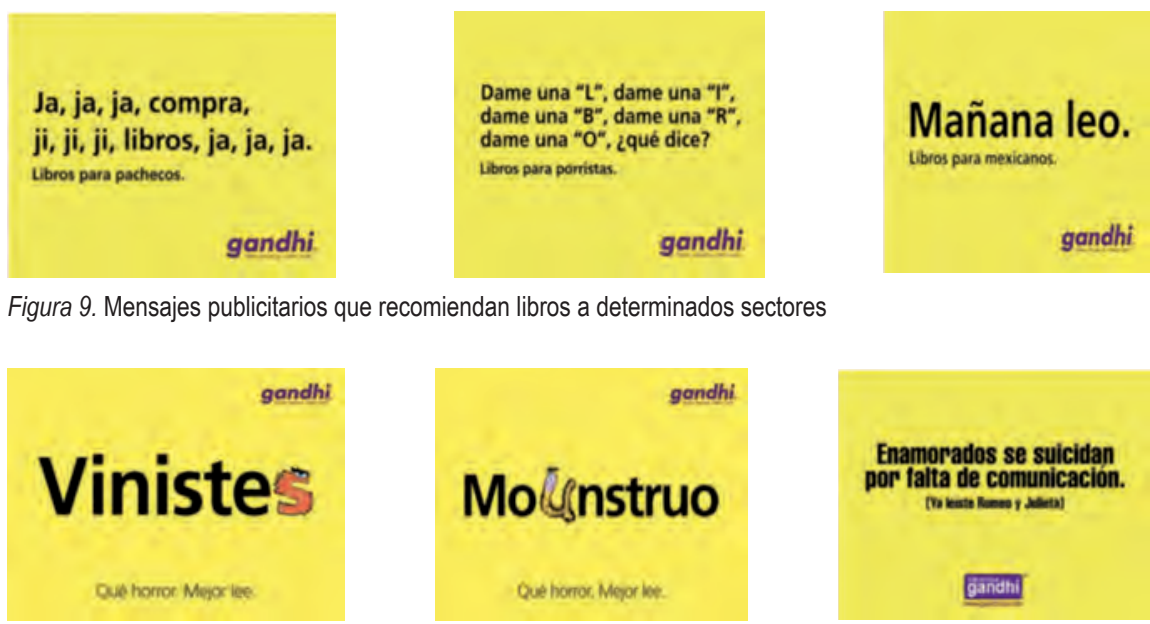

Figura 9. Mensajes publicitarios que recomiendan libros a determinados sectores

Figura 10. Para no cometer errores, la publicidad recomienda que se lea.
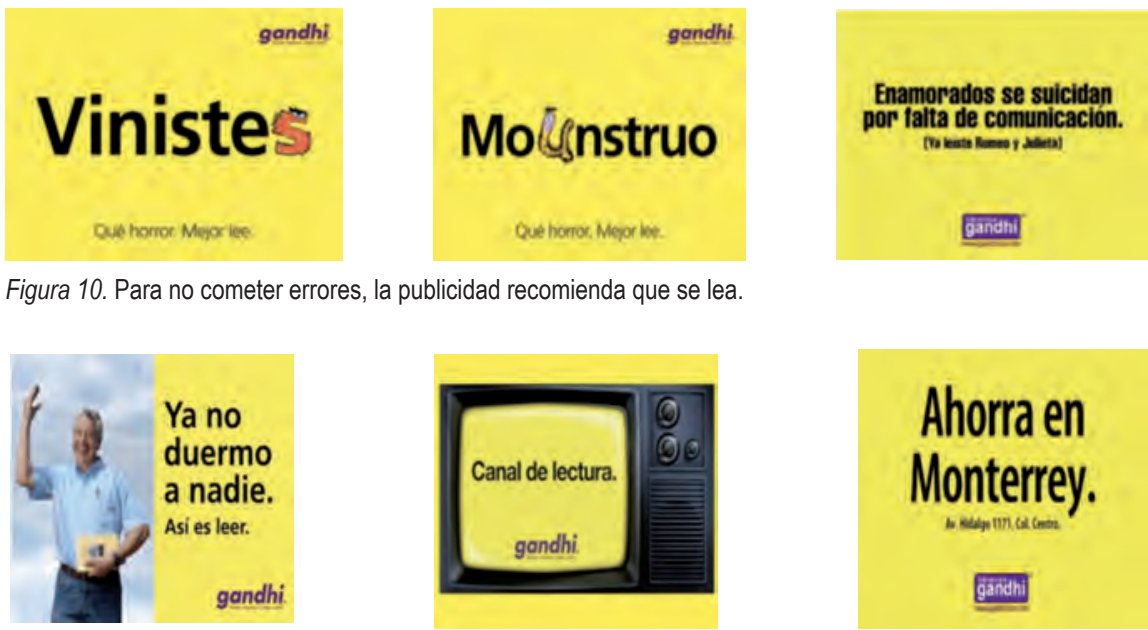

Figura 10. Para nocometer errores, la publicidad recomienda que selea.

Figura 11. Publicidad para la apertura de nueva tiendas y sucursales 
Otras actividades publicitarias: las redes sociales

La publicidad en los medios de comunicación es cada vez más complicada. La llegada de las redes sociales ha supuesto una dispersión de las audiencias, de ahí que en Gandhi hayan apostado por otras formas de hacer publicidad y de dar a conocer sus actividades. Sobre todo, se ha apostado por estar en las redes sociales. Así, Alberto Achar informa que disponen de 20 canales en las redes sociales, con unos 270000 usuarios en Facebook y más de 60000 en Twitter. Además cuentan con más de 800000 visitas mensuales a su página web y han creado un APP Store para Gandhi. Eso en cuanto a redes sociales.

El esfuerzo publicitario y de comunicación de Gandhi incluye otras actividades como por ejemplo los eventos culturales de cada mes que se envían a través del correo a miles de suscriptores (Figura 12), y que recoge las actividades culturales que se harán durante un mes, con los datos de quien las imparte, la hora y el lugar. A juicio de Achar también es interesante el medio + Cultura (Figura 13), un canal digital de información sobre el mundo cultural de México y del resto del mundo y que tras su presentación ha tenido una buena acogida por parte de los lectores y usuarios de Gandhi.
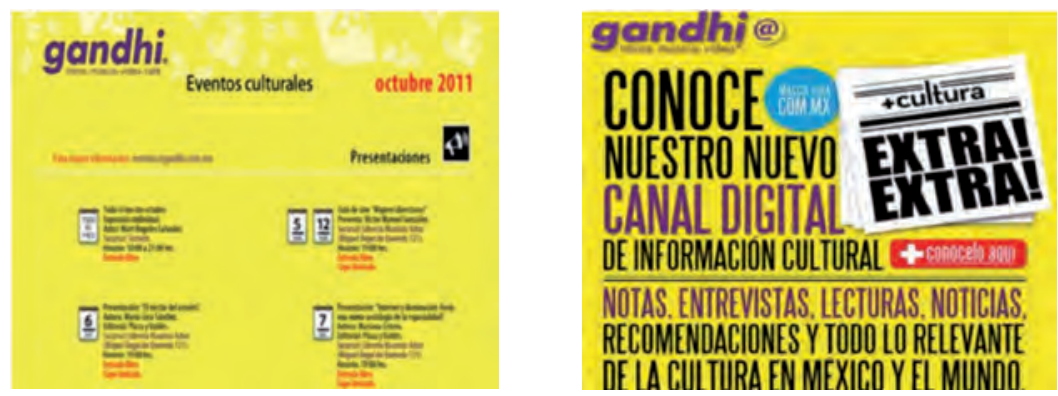

Figuras 12 y 13. Dos propuestas informativas para acercar lectores a Gandhi

Si importante es la lectura, también lo es conseguir que los lectores se acerquen a las tiendas. Según datos recientes aportados por el gerente de Mercadotecnia hay un tránsito de más de 350000 
personas al mes que visitan sus 25 puntos de venta en los que además pueden comprar certificados de regalo (tarjetas de regalo), unas 25000 al año.

La publicidad también se logra en lugares como YouTube y con acciones de mercadotecnia viral, donde han conseguido más de 500000 views de las propuestas de Gandhi. Con respecto a los formatos más usados, Alberto Achar señala que cada año se hacen unos 3000000 de bolsas, unos 800000 separadores y todo ello supone más de tres millones de impactos al año, recalcando que con poca inversión se han logrado grandes récords de venta. Por último, se ha creado una página para clientes preferentes en la que ya hay más de 65000 socios.

Además destacan también las actividades puntuales que la librería ofrece a sus suscriptores o amigos, a través del correo. Por ejemplo, si compras tal libro, lo llevas firmado; o si compras tal otro tienes un descuento; o si compras más te lo entregamos con una bolsa.

La publicidad precisa de la atención del consumidor, es una llamada constante hacia la marca para que siga creyendo en ella. Pues bien, en el caso de Gandhi además de utilizar personas comunes y corrientes en alguna de sus campañas, las invita a participar en concursos para que formen parte de la publicidad que luego se verá en sus espectaculares. Así, el año pasado crearon un concurso para hacer espectaculares (Figuras 14 y 15) y luego se publicaron los ganadores.
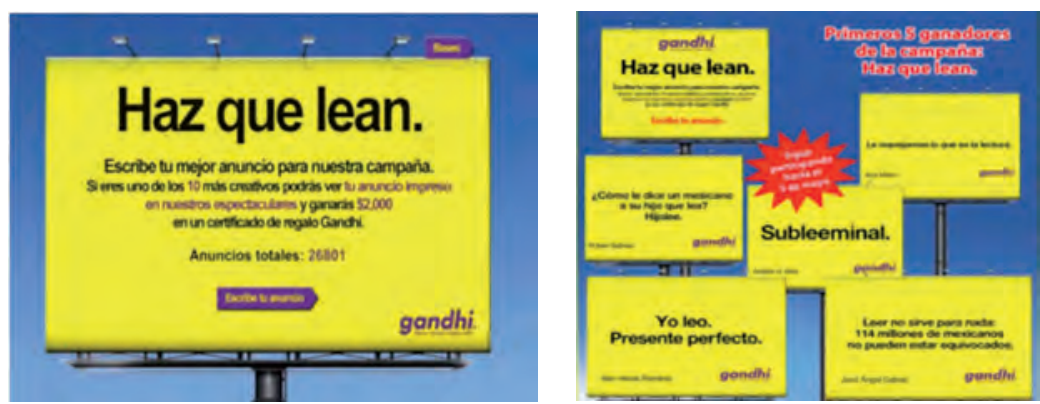

Figuras 14 y 15. Concurso para que la gente lea 
Por último Gandhi trabaja con la agencia mexicana Ogilvy, encargada de algunas campañas que han impactado a la sociedad mexicana. Tres de las últimas se señalan aquí: Ogilvy instaló trece vallas en la línea amarilla del metro de México DF con fragmentos de un cuento de Kafka (Figura 10).

En un país donde la media de lectura es de 2.7 libros al año por persona, la librería Gandhi ha puesto en marcha una acción de guerrilla en el metro de la ciudad de México con el fin de mejorar tan descorazonador dato. Dado que el metro es un lugar tan bueno como cualquier otro para disfrutar de la lectura, la idea era hacer que los pasajeros leyeran un cuento completo de Franz Kafka. Para ello, la agencia Ogilvy México colocó trece fragmentos del relato en sendas vallas alineadas frente a los vagones -customizados con el amarillo característico de Gandhi- para que los usuarios pudieran leerlos a través de ventanas y puertas. Paralelamente, se repartieron folletos con el cuento completo (Marcos Recio, 2010a).

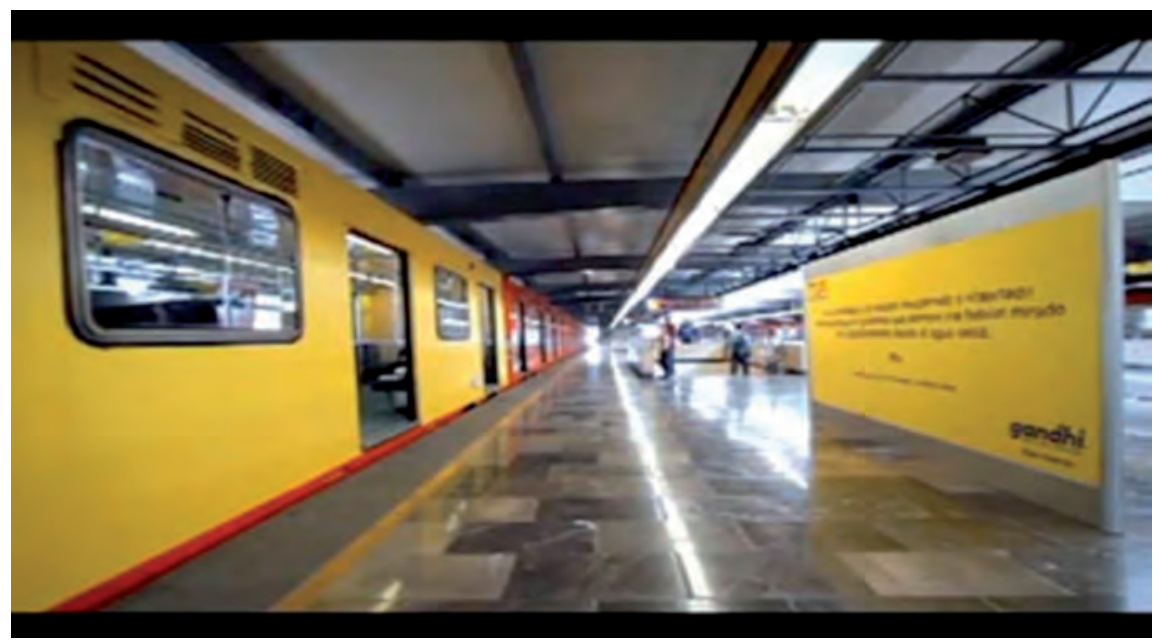

Figura 16. El metro de México convertido en centro de lectura

Otro trabajo de la misma agencia consistió en instalar unas letras en el bosque de Chapultepec con el fin de jugar con la ilusión óptica para incitar a la lectura. Se instalaron enormes letras blancas entre los árboles del parque que, a primera vista, no tenían 
significado alguno. Pero si uno se detenía a leer desde diferentes perspectivas las letras acababan por formar palabras con mucho sentido: "Leer cambia tu perspectiva. Sigue leyendo. Librerías Gandhi”.

En la tercera campaña se presentó El Principito 2.0, en la que adaptando al medio digital una de las grandes obras de la literatura universal se pretende fomentar la lectura usando personajes creados en Twitter. Se trata de un microsite al que la gente acude también para buscar información y sobre todo para leer capítulo a capítulo el libro. Es un formato menos convencional pero igual de válido. El director de los servicios creativos de Ogilvy México, Pepe Montalvo, explica las estrategias empleadas: "Twitter tiene mucho de literario, es escribir y leer. La idea nació con el objetivo de que el usuario pudiera leer una obra clásica de la literatura en su timeline y así promover la lectura. [...] La campaña tiene como objetivo crear un vínculo emocional con la marca al promover la lectura de una forma menos convencional" (Adlatina, 2010).

Todas estas acciones publicitarias sumadas hacen de Gandhi una librería puntera en ventas, pero también un lugar de desarrollo cultural, de fomento de la lectura, de presentación de libros y de encuentros que amplían las posibilidades de una biblioteca.

\section{CONCLUSIONES}

La utilización de la publicidad por editoriales y librerías permite el incremento en sus ventas y aumenta de forma importante la lectura. Para ello se han de crear campañas, publicidad gráfica (espectaculares), separadores y bolsas, etc., con el fin de transmitir un mensaje directo, activo y con un fino toque de humor, mostrando las ventajas para los que ya son lectores y lo que se pierden quienes no lo son. Si bien es el Estado, el sector de la educación y las fundaciones quienes deben encargarse de fomentar la lectura, el hecho de que lo hagan también las editoriales y librerías significa un mayor reconocimiento profesional a su tarea, ya que además de vender libros abren sus puertas a la cultura en general. 
Oportunidades y retos en la formación, investigación y aplicación...

En este estudio preliminar con Gandhi se constata el uso de las redes sociales por parte de las librerías para publicitar y comercializar los libros, así como interactuar con los clientes y en consecuencia obtener interesantes resultados. Además, el mercadeo y la publicidad son dos canales con apuesta permanente en la difusión y comercialización de los libros.

Por último se hace necesario completar la investigación con otras librerías mexicanas y españolas a fin de constatar muchas de las aseveraciones de este artículo. Del mismo modo es de gran interés el papel que juegan las editoriales en este tema, dado que son las empresas creadoras. Sólo remando todos (estado, universidades, librerías, etc.), en la misma dirección, los procesos de lectura mejorarán en la sociedad y con ellos habrá una mejor educación para todos.

\section{Bibliografía}

"El analfabetismo en España se ha reducido a la mitad en los últimos 25 años", en Información [en línea], http://comunidadescolar.educacion.es/734/info5.html Consulta: 1 septiembre 2011.

Campero Cuenca, Carmen et al. (2008), "Desarrollo y el estado de la cuestión sobre el aprendizaje y la educación de adultos", en Unesco [en línea], http://www.unesco.org/fileadmin/MULTIMEDIA/INSTITUTES/UIL/confintea/pdf/National_Reports/Latin\%20 America\%20\%20Caribbean/mexico_documento_complementario.pdf Consulta: 1 septiembre 2011.

González Martín, J. A. (1996), Teoría general de la publicidad, Madrid, FCE.

Hualde, Marta (2008), "España cuenta con un millón de analfabetos", en Público.es [en línea], http://www.publico.es/espana/177157/ espana-cuenta-con-un-millon-de-analfabetos/version-imprimible Consulta: 27 septiembre 2011.

INEGI, Características educativas de la población: población de 15 $y$ más y porcentaje de la misma que es alfabeta por entidades federativas [en línea], http://www.inegi.org.mx/sistemas/sisept/ 
Default.aspx?t=medu16\&s=est\&c=26361 Consulta: 27 septiembre 2011.

Características educativas de la población: población de 8 a 14 años y más y porcentaje de la misma que es alfabeta por entidades federativas [en línea], http://www.inegi.org.mx/sistemas/sisept/Default.aspx?t=medu15\&s=est\&c=26363 Consulta: 27 septiembre 2011.

, Estadística a propósito del día internacional de la alfabetización [en línea], http://www.inegi.gob.mx/inegi/contenidos/ espanol/prensa/contenidos/estadisticas/2006/alfabetizacion06. pdf Consulta: 27 septiembre 2011.

Marcos Recio, Juan Carlos (2009), "Librerías Gandhi sorprende una vez más con El Principito 2.0”, en Publidocnet [en línea], http:// multidoc.rediris.es/publidocnet3/index.php?option=com_conten t\&task=view\&id=4916\&Itemid=41 Consulta: 27 septiembre 2011.

(2010a), "Ogilvy México crea para Gandhi Metro Libro", en Publidocnet [en línea], http://multidoc.rediris.es/publidocnet3/ index.php?option=com_content\&task=view\&id=6055\&Itemid=1 Consulta: 27 septiembre 2011.

(2010b), "Llevar la lectura al parque o cómo fomentar la lectura", en Publidocnet [en línea], http://multidoc.rediris.es/publidocnet3/index.php?option=com_content\&task=view\&id=6013\&Ite mid=1 Consulta: 27 septiembre 2011.

Unesco (2007), Informe del seguimiento de la Educación para todos en el Mundo 2007 [en línea], http://www.unesco.org/education/efa/gmr2006_download/ECCE_outline_es.pdf Consulta: 27 septiembre 2011.

Unesco (s.a.), "Alfabetización a nivel mundial" [en línea], http:// www.unesco.org/education/uie/confintea/pdf/3a_span.pdf Consulta: 27 septiembre 2011.

Vélaz de Medrano, Consuelo (2006), Informe sobre la alfabetización en España, [en línea] Unesco, http://unesdoc.unesco.org/ images/0014/001462/146205s.pdf Consulta: 1 septiembre 2011. 



\title{
Las dimensiones de los datos: una combinación de tradiciones bibliográficas y oportunidades de cambio
}

\author{
Ariel Alejandro Rodríguez García \\ Instituto de Investigaciones Bibliotecológicas \\ $y$ de la Información, UNAM
}

\section{INTRODUCCIÓN}

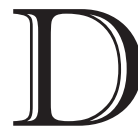
esde hace un par de décadas el registro bibliográfico está siendo objeto de estudio. De ser considerado como un registro monolítico, éste ha evolucionado a un registro que permite desagregar los datos y dimensionarlos, de tal manera que la recuperación de la información pueda, por ejemplo, efectuarse con una sola consulta.

A propósito de lo anterior se ha dicho en el entorno de la actividad de los metadatos y la web, que los datos bibliográficos se crearon para ser interpretados por los bibliotecarios y el usuario. Algunos de esos datos es posible encontrarlos únicamente por medio de campos controlados. Pero el énfasis que se les quiere otorgar ahora es que esos datos puedan almacenarse por los sistemas de cómputo y ser desplegados en la pantalla para que de esta manera el catálogo de la biblioteca siga ocupando su lugar dentro de los servicios bibliotecarios.

De ser cierto lo anterior podemos afirmar que los Requerimientos Funcionales para los Registros Bibliográficos introdujeron un nuevo modelo conceptual para representar el universo bibliográfico y encontrarle una lógica natural a los datos bibliográficos en función de lo que se entiende por entidades, atributos y relaciones fuertemente vinculadas con las cuatro tareas genéricas que realiza el usuario (seleccionar, encontrar, identificar y obtener) al aprovechar la información bibliográfica. 
Este trabajo tiene como objetivo fundamental, desde un punto de vista bibliotecológico, decir cómo los datos bibliográficos analizados desde la perspectiva del modelado de los datos entidadrelación intentan resolver los diversos problemas que existen en torno a la comprensión del universo bibliográfico, y ayudar a los catalogadores a cambiar las estructuras, juicios y posturas cuando toman decisiones al crear un registro bibliográfico.

En primer lugar, a través de un recorrido sobre cómo se ha analizado el registro bibliográfico en el modelo conceptual de los Requerimientos Funcionales, pretendemos demostrar que las aportaciones que hace éste permiten observar distintas soluciones en el orden lógico de los datos, y consecuentemente en el desarrollo efectivo de los mecanismos para recuperar información en los catálogos en línea.

En segundo lugar, pero muy ligado a lo anterior y dentro del propósito general de este trabajo consideramos importante examinar los cambios que han tenido el principio de representación, el juicio y toma de decisiones del catalogador.

Finalmente teniendo como marco la idea general de trabajo, intentaremos mostrar cómo la metodología propuesta por el modelo de los requerimientos conceptuales permite analizar los datos bibliográficos desde una perspectiva actual e innovadora que se enmarca en el entorno de los modelos de metadatos de la World Wide Web y el desarrollo del nuevo código de catalogación, de descripción y acceso a los recursos (RDA por sus siglas en inglés).

\section{EL REGISTRO BIBLIOGRÁFICO: DE MONOLÍTICO}

A SU RELEVANCIA EN EL ENTORNO DIGITAL

En primer lugar nuestro interés por conocer qué se ha dicho sobre el registro bibliográfico surge, al menos en parte, como resultado de las diversas investigaciones que en 1990 aproximadamente se vienen realizando sobre el futuro del Control Bibliográfico Universal en un mundo en el que constantemente se incrementa el volumen de las publicaciones, así como la ampliación del rango de 
los multimedia, los discos compactos y los recursos de información digital, entre otras cosas más.

También los estudios que sirven como sustento teórico y le dan origen al modelo conceptual de los Requerimientos Funcionales para los Registros Bibliográficos, nos han hecho tomar conciencia de la importancia que reviste el modelado de datos de la información bibliográfica y, sobre todo, de nuestro acercamiento al nuevo código de catalogación.

En efecto, el Seminario sobre los Registros Bibliográficos ${ }^{1}$ y las aportaciones realizadas por Svenonius $^{2}$ nos brindan en la actualidad un corpus considerable de conocimientos sobre lo que se entiende por este tipo de registro. En ambos trabajos, Svenonius señaló que a lo largo de la historia de la catalogación el registro ha servido para describir las entidades bibliográficas que se encuentran formalmente inscriptas en algún medio.

Como en todo, la forma del registro ha cambiado principalmente en respuesta a los avances en la tecnología. Por ejemplo en la era de Panizzi los registros eran elaborados para darle forma al catálogo en forma de libro. Esta idea funcionó durante la primera parte del siglo xx y se estableció en lo que sería el catálogo en forma de tarjeta, y después se retomó para dar origen al catálogo electrónico, el cual comenzaría a utilizar formatos bibliográficos para crear registros legibles por máquina y así crear el catálogo en línea actual.

En este punto es forzoso reconocer que pese a los esfuerzos realizados en los últimos años, los conocimientos sobre el registro bibliográfico son mucho más limitados. Esto por una serie de circunstancias relacionadas que han imperado en dos aspectos que no pueden aclararse en el actual entorno digital, como es lo indicado por Svenonius, ${ }^{3}$ donde el registro describe las características, así como las ediciones de las manifestaciones de una entidad bibliográfica.

1 Seminar on Bibliographic Records, "Proceedings of the Seminar Held in Stockholm, 15-16 August 1990". Paper presented at the, Stockholm, 1992, p.1

2 Elaine Svenonius, The intellectual foundation of information organization, pp. 62-66.

3 op. cit., p. 64. 
Por definición, autores como Heaney, ${ }^{4}$ Leazer, ${ }^{5}$ Gredley y Hopkinson, ${ }^{6}$ entre otros más, han hecho evidente que el registro bibliográfico presenta una serie de inconsistencias en su conceptualización, motivo por el cual no es sencillo entender el modelo entidad-relación que impera en la creación de bases de datos.

De tal forma el actual registro que da sentido a las bases de datos de información bibliográfica muestra lo complicado que es comunicar las características de las entidades del universo bibliográfico en un entorno global, porque los datos complementarios que son necesarios para realizar las operaciones internas de una computadora requieren la desintegración de éstos para mantener al actual catálogo en línea de la biblioteca.

Urge por tanto completar la concepción del registro bibliográfico desde la perspectiva de la praxis, la implementación y las reglas con que están diseñados, como lo indica Svenonius ${ }^{7}$ en su lenguaje bibliográfico, y los creadores del Formato marc; es decir, urge repensar las explicaciones del proceso de catalogación desde la plataforma, lo que supone aceptar con todas sus consecuencias que, al menos en el modelo $\mathrm{RFRB},{ }^{8}$ el registro bibliográfico conforma

4 Michael Heaney, "Object-Oriented Cataloging", en Information Technology and Libraries, p. 139 .

5 Gregory H. Leazer, "An examination of data elements for bibliographic description: toward a conceptual schema for the US MARC formats", en LRTS, p. 192.

6 E. Gredley y A. Hopkinson, Exchanging and bibliographic data: MARC and other international formats, p. 9.

7 Elaine Svenonius, op. cit., p. 59.

8 En el informe final sobre los FRBR, el registro bibliográfico se define como "la suma de datos asociados a las entidades descritas tanto en los catálogos de bibliotecas como en las bibliográfias nacionales. Forman parte de este conjunto de datos los elementos de datos descriptivos definidos por las Descripciones Bibliográficas Internacionales (ISBD); los elementos de datos utilizados en encabezamientos de personas, entidades corporativas, títulos y materias que se utilizan como instrumento de indización o entradas de índices; otros elementos de datos utilizados para organizar un fichero de registros, tales como números de clasificación; anotaciones como abstracts o sumarios; y datos específicos de los ejemplares de las colecciones de las bibliotecas, como signaturas topográficas o sistemáticas". 
un conjunto de datos que pueden disociarse y dar origen al nuevo registro que se quiere.

Mientras eso no suceda la concepción del registro bibliográfico continuará siendo una explicación con gran potencial heurístico para la catalogación, pero seguirá teniendo limitaciones considerables para transformar ese potencial en las propuestas concretas que se buscan para operar los cambios en el catálogo de la biblioteca.

\section{LA FUNCIÓN Y FORMA DEL REGISTRO BIBLIOGRÁFICO} EN EL ENTORNO DIGITAL

En segundo lugar estamos de acuerdo con aquellos autores que han señalado en repetidas ocasiones que, más que necesario, es urgente hacer cambios o modificaciones en la estructura del registro bibliográfico; es necesario y fundamental entender cómo va a responder éste a los nuevos alcances de la tecnología. En el modelado conceptual entidad-relación, se establece que para que suceda una interacción entre los datos deben existir tres elementos básicos: las entidades, las relaciones y los atributos.

Wilson ${ }^{9}$ refiere que la catalogación descriptiva (el catálogo) se encontraba en un estado de desaparición hasta que aparece el catálogo en línea, sustituto natural del catálogo en tarjetas. La incorporación de la tecnología de la información hizo posible la reutilización y reencausación de los objetivos del catálogo. Por ejemplo, si un catálogo es una guía para entender las colecciones disponibles en un lugar, entonces ese catálogo deberá incluir las copias virtuales tanto como aquello que también se encuentra in situ.

En contra de lo anterior Wilson ${ }^{10}$ afirma que los catálogos en línea creados con la tecnología de la información deberían de asumir su elaboración de acuerdo con el segundo objetivo propuesto por Cutter, y reflexiona en torno a la obra y sus derivados acerca de lo

9 Patrick Wilson, "The second object", en The conceptual foundation of descriptive cataloging, p. 7

10 Idem. 
que puede encontrarse en la colección de la biblioteca. Es decir, cambiar aquella afirmación que por muchos años ha sido admitida: la representación del ítem y la obra están por encima de los intereses del usuario.

Si la catalogación descriptiva y el catálogo en línea toman seriamente la representación de la obra, podremos entonces reorganizar el catálogo sustrayendo la importancia que tiene la obra y, así, asegurar el cambio sustancial en cuanto a la división que existe entre el catálogo local y el catálogo de unión; y se borrará la relación que existe entre catálogo e índice, catálogos y bibliografías. También la catalogación descriptiva desaparecerá como una especialidad separada y surgirá como la descripción bibliográfica en general.

La concepción de los datos en las tradiciones bibliográficas nos remite a la revisión del modelo conceptual ${ }^{11}$ creado por las normas internacionales para hacer la descripción bibliográfica, las reglas de catalogación y adoptar el uso del Formato MARc. La práctica de la catalogación con base en esas normativas seguramente más de una vez nos habrá provocado interrogantes y dudas con relación al papel que esta catalogación juega en las diferentes bases de datos bibliográficas. Nos habremos preguntado, por ejemplo:

* ¿Cómo hemos registrados los datos?

* ¿Cuándo cambio la manera de elaborar las descripciones de las entidades?

¿Para qué me sirve el registro bibliográfico?

*Qué aspectos deberán tomarse en cuenta, además de los que nos determinan, por ejemplo, las reglas de catalogación?

* ¿Cómo considerar las particularidades de cada una de las entidades, principalmente aquellas que responden a la información digital?

Esa perspectiva fue la que nos ayudó a encontrar que el proceso de catalogación estaba mal estructurado tal como lo entendíamos. Es decir que carecía de una estructura lógica que permitiera

11 Allyson Carlyle, "Understanding FRBR as a Conceptual Model: FRBR and the bibliographic universe", en LRTS, pp. 267-268. 
agrupar los datos de los registros bibliográficos de tal manera que pudiéramos encontrarlos sin mucho esfuerzo. En algún momento perdimos de vista los cambios que iban ocurriendo en el mercado editorial, y no dimensionamos adecuadamente el explosivo crecimiento de Internet y la web.

El FRBR COMO METODOLOGÍA PARA EL ANÁLISIS DE DATOS BIBLIOGRÁFICOS

En tercer lugar, los Requerimientos Funcionales permiten generalizar los atributos de las entidades que han sido identificadas en el universo bibliográfico; se trata de una estructura independiente de cualquier código de catalogación o formato bibliográfico. Es un modelo que ha ofrecido, desde hace unos 10 años, una nueva perspectiva para entender, analizar y estructurar los registros bibliográficos de otro modo, y nos ha llevado a ajustar el vocabulario existente en la normativa bibliográfica.

Con base en lo que señala Pisanski, Žumer y Aalberg, ${ }^{12}$ respecto a contar con un modelo como los Requerimientos, se admite que éstos son una ayuda para que usuarios y profesionales entendamos mejor el universo bibliográfico. Los Requerimientos nos proporcionan un sistema que representa los datos bibliográficos y que es más fácil de emplear. Su uso nos ofrece la posibilidad de eliminar la duplicación de los datos bibliográficos, y además, de establecer un orden nos ofrece la posibilidad de alinear las bases de datos de una biblioteca en un auténtico entorno de redes.

La dificultad que se ha observado en el uso de los Requerimientos Funcionales está en el análisis de las pequeñas bases de datos, puesto que se carece de la cantidad necesaria de datos sobre las obras y sus respectivas expresiones y manifestaciones. De ahí que el alcance global de este modelo únicamente se pueda observar

12 Jan Pisanski, Maja Žumer y Trond Aalberg, "Frbrisation (frbrización): por un futuro prometedor de las bibliográficas nacionales", en World Library and Information Congress: 75th IFLA General Conference and Council. 
en grandes conjuntos de datos bibliográficos, por ejemplo, en los catálogos de las bibliotecas nacionales.

La metodología empleada en los Requerimientos Funcionales, según Madison, ${ }^{13}$ Tillett $^{14}$ y Riva, ${ }^{15}$ está pensada en función de los dos aspectos principales: las tareas del usuario y las relaciones entre las entidades. El primero consiste en identificar los intereses y acciones que el usuario realiza para usar la información bibliográfica; el segundo determina las formas en que interactúan los atributos de las entidades para crear un sistema teórico que facilite el acceso a los contenidos más que a las características de las entidades.

A propósito de lo anterior, Coyle ${ }^{16}$ refiere que el modelo que subyace en los Requerimientos define el universo bibliográfico con la posibilidad de racionalizar la práctica de la catalogación en un entorno donde han comenzado a predominar los recursos con versiones múltiples y todo aquello que aparece en la web, pero también han disminuido las actividades relacionadas con la catalogación original, y ha aumentado la descarga de documentos en texto completo.

Nos gustaría que se comprendiera que para haber llegado a este punto, ha sido necesario replantear tres principios y conceptos básicos que están presentes en las Reglas de Catalogación Angloamericanas, segunda edición revisada, y éstos principios son: el concepto de autoría y la entrada principal; la descripción de la copia que se tiene a la mano (principio cardinal de la catalogación) y la forma autorizada para elaborar el punto de acceso.

El análisis de estos principios y conceptos básicos fueron los temas de discusión en la Conferencia de Toronto en 1997 y se llegó a la conclusión de que son éstos los fundamentos implícitos en la

13 Olivia M. A. Madison, "Utilizing the FRBR Framework in Designing User-Focused Digital Content and Access Systems", en LRTS, pp. 10-15.

14 Barbara Tillett, "FRBR and Cataloging for the Future", en Cataloging E Classification Quarterly, pp. 197-205.

15 Pat Riva, "Introducing the Functional Requirements for Bibliographic Records and Related IFLA Development", en Bulletin of the American Society for Information Science, pp. 7-11.

16 Karen Coyle, "Cataloguing rules for the 20th century", en D-Lib. Magazine. 
tradición bibliográfica anglosajona, aunque no son los mismos para otras comunidades de catalogación que hay en el mundo.

En este momento no es posible explicar cada uno de esos fundamentos, porque éstos han quedado registrados como parte de la historia moderna de la catalogación, y la mayoría de estas aportaciones han enfatizado diferentes aspectos, lo cual ha propiciado un importante y nuevo desarrollo de técnicas y metodologías en el proceso de catalogación.

Explicado de otra forma y como se hace actualmente, el proceso de catalogación tiene como punto de partida la entidad (item), pero toma en cuenta los atributos de la tercera entidad que es conocida como manifestación. Esta manera de catalogar ha sido la causante de varios conflictos de aplicación del método al describir los diversos materiales; de ahí la pregunta ¿qué es lo que se está haciendo en la catalogación?

Es evidente que todo lo que se ha hecho en torno al análisis, actualización y reestructuración del registro bibliográfico nos lleva a un punto de discusión: ¿cuál es la gran diferencia que tiene el análisis de datos con los Requerimientos y aquél que se hace con las Reglas de Catalogación A2? La respuesta es que quizá es tiempo de redirigir nuestros esfuerzos para crear los registros bibliográficos que respondan a los nuevos cambios tecnológicos aparecidos también con las bases de datos.

\section{El REGISTRO BIBLIOGRÁFICO RUMBO A SU ANÁLISIS COMO DATOS}

El punto de partida que se tiene sobre el análisis de los datos bibliográficos son los acuerdos y desacuerdos que surgen a partir de la Conferencia de Toronto sobre las estructuras lógicas de las reglas, las relaciones bibliográficas y los saberes sobre el contenido y lo que lo contiene. Así como también la interpretación que se haga de las entidades y de las relaciones primarias del grupo 1 de los Requerimientos (RFRB), y la ruptura que también se tiene que hacer con la dicotomía soporte-contenido que le da sustento a los principios y conceptos básicos de las Reglas de Catalogación. 
Durante los últimos años, las diversas comunidades bibliotecológicas han sido testigos de una apertura sin precedentes en cuanto al análisis de los registros bibliográficos, gracias a la cual el proceso de catalogación se ha enriquecido y permite una mayor participación del catalogador, de ahí que el año 2010 haya sido declarado como el año de la investigación en catalogación. En este contexto es hoy una necesidad apremiante aprender a entender el registro bibliográfico en su lógica esencial como "una representación de manifestaciones", pero eso implica también una dinámica y un nivel de abstracción que raramente explican la comprensión exacta de una expresión, por la sencilla razón de que tal expresión no está entre los elementos obligatorios de los códigos de catalogación.

Quizás uno de los efectos que influyen en ese desconocimiento es el que marcó Howarth, ${ }^{17}$ en el análisis de la regla 0.24 como "principio cardinal" de las Reglas de Catalogación, que señala rotundamente que el enfoque descriptivo está orientado hacia el concepto obra. Así que en la catalogación hágase lo que se haga siempre se identificará el soporte de la entidad como atributo significativo del alto nivel de entendimiento en el modelo.

Con la práctica de la catalogación se tiene una buena oportunidad para observar la manera en que se elabora el registro bibliográfico, y esto es esencial para comprender el por qué de lo enmarañado de todo este asunto. Si el catalogador no delimita apropiadamente las tres etapas de la práctica (identificación, descripción y transcripción ${ }^{18}$ ) su proceso será pobre e incorrecto, por la sencilla razón de que tuvo fallas o descuidos en la sistematización de los datos.

El registro bibliográfico como se configura actualmente se constituye de varias partes similares a la descripción bibliográfica de una manifestación por una parte, y con la representación gráfica de las tarjetas o fichas del catálogo, por la otra. Es decir, se configura de cuatro partes que son el asiento principal, las áreas y elementos de

17 Lynne C. Howarth, "Content versus carrier", en Principles and futures of AACR..., pp. 148-150.

18 Ariel Alejandro Rodríguez García, "Elementos de la descripción bibliográfica", en Organización bibliográfica y documental, pp. 15-41. 
descripción, la clasificación y el área de registro o temática, todas las cuales están lógicamente ordenas de acuerdo con las reglas y normas para la descripción bibliográfica y la codificación legible por máquina.

En la misma línea Gorman ${ }^{19}$ contextualiza el registro señalando que consiste en un número de pasos complejos, el primero de los cuales es describir siguiendo lo establecido por las Normas de Descripción Bibliográfica. Después se asignan los puntos de acceso como nombres, título uniforme, encabezamientos de materia y notación. Y finalmente se codifica todo esto de acuerdo con las versiones del formato bibliográfico usado por la biblioteca.

En tanto que Garrido Arilla ${ }^{20}$ menciona que es un producto que nos permitirá identificar e indicar tanto los datos formales como los aparentes del documento original.

Por su parte, Hagler $^{21}$ refiere que un registro bibliográfico puede describir un documento como un objeto físico sin ignorar su contenido intelectual, pero no viceversa. Puede ser el puente entre la información intangible (obra) y su contenedor tangible (documento), y también conducir al usuario hacia el contenido informativo que le sea de utilidad; por ejemplo, para hacer inventarios de los ítems físicos disponibles en un estante destinado a la compra o a algún otro fin, como la venta por ejemplo.

En el contexto del modelo conceptual de los Requerimientos Funcionales, el registro bibliográfico:

se define como la suma de datos asociados a las entidades descritas tanto en los catálogos de bibliotecas como en las bibliográficas nacionales. Forman parte de este conjunto de datos los elementos de datos descriptivos definidos por las Descripciones Bibliográficas Internacionales (ISBD); los elementos de datos utilizados en encabezamientos

19 Michael Gorman, “¿Metadatos o catalogación?: un cuestionamiento erróneo”, en Internet, metadatos y acceso a la información en bibliotecas y redes en la era electrónica... p.

20 María Rosa Garrido Arilla, "Procedimientos automáticos de creación y transformación de los registro bibliográficos”, en Anales de Documentación, p. 127.

21 Ronald Hagler, The bibliographic record and information technology, p. 15. 
Oportunidades y retos en la formación, investigación y aplicación...

de personas, entidades corporativas, títulos y materias que se utilizan como instrumento de indización o entradas de índices; otros elementos de datos utilizados para organizar un fichero de registros, tales como números de clasificación; anotaciones como abstracts o sumarios; y datos específicos de los ejemplares de las colecciones de las bibliotecas, como signaturas topográficas o sistemáticas.

En suma la práctica de la catalogación no es solamente la sistematización de datos sino un proceso mental y de conocimientos técnicos y normativas que son necesarios para el correcto desarrollo del registro y finalmente del catálogo de la biblioteca encargado de proporcionar servicios y productos.

\section{LOS FUNDAMENTOS ADECUADOS DE LOS DATOS BIBLIOGRÁFICOS}

Durante décadas los trabajos de investigación en descripción bibliográfica se habían caracterizado por ser pragmáticos. La sola idea de que era necesaria la utilización de las estadísticas para reportar, por ejemplo, los materiales que se adquirían, catalogaban y clasificaban en un departamento de servicios técnicos, era causa de complicaciones para el equipo de trabajo. Hoy en día la descripción bibliográfica puede verse como un sistema matemático.

El nuevo enfoque del modelado de datos para los requerimientos funcionales rompe con el tradicional esquema de la creación de registros compactos sobre las características de las entidades que conforman el universo bibliográfico, donde antes predominaba la técnica de la descripción como una caja receptora de datos y lo importante era llenarla con las posibles respuestas que se podían ofrecer por medio de los medios de recuperación del autor, el título y los temas; y no importaba lo que ocurriera dentro de esa caja.

De acuerdo con Minder, ${ }^{22}$ los elementos básicos de la organización bibliográfica son el conocimiento y la información, ambos, o el

22 Thomas Minder, "The mathematical foundations of bibliographic organization", en American Documentation, p. 2. 
universo de la organización bibliográfica, es todo aquello que tiene importancia para los hombres: su pasado, su presente y su futuro.

Éste pareciera un planteamiento correcto y razonable, pero muchas de las investigaciones han mostrado cómo esos elementos básicos nos llevan a replantear constantemente, no sólo el contenido y la descripción de las propias entidades, sino también los soportes en que son registrados el conocimiento y la información, como condicionantes que nos ayudan a enfrentar los retos impuestos por las tecnologías de la información y el conocimiento; por tanto la descripción bibliográfica se ha ido alejando del pragmatismo de los inicios de los años sesentas para acercarse a un procedimiento normalizador y unificador de los datos bibliográficos.

Dentro de los conceptos del nuevo enfoque que se quiere dar en la descripción bibliográfica, el registro de los datos de las entidades ya no es suficiente, importa ahora ese otro espacio que brinda las posibilidades para relacionar semánticamente los datos; es decir, la asociación en red de las palabras.

Recordemos que el concepto de red semántica fue desarrollado por Quilian en 1968 como un artificio que permite modelar el conocimiento a través de los lenguajes orientados hacia los objetos. La mayor parte de las estructuras creadas en el contexto de esos modelos se sustenta en tres estructuras como son, según Sanders, la relación Is-part-of, facilita la construcción de dependencias de los componentes; la relación $I s$ - $a$ que es inherente a las entidades; y la relación Is-associatied-with constituye la interacción que hay entre las entidades.

Las relaciones bibliográficas existen en el momento en que las entidades son asociadas unas con otras, éste es el punto de partida que Tillett ${ }^{23}$ considera al examinar la alianza entre ciertas virtudes o características compartidas por esa entidad que se encuentra en las bases de datos de la información bibliográfica; por ejemplo, el idioma, el lugar de publicación, el editor y el tamaño físico, entre otras características más, que varían con la propia entidad.

23 Barbara Tillett, "A taxonomy of bibliographic relationships", en LRTS, p. 150. 
Son siete las relaciones bibliográficas que pueden establecerse en un registro. Sin embargo cabe preguntarse: ¿serán reemplazadas algunas de estas relaciones con la aparición del nuevo código de catalogación? ¿Se mantendrá la supremacía del modelo área, elemento, dato en la descripción bibliográfica?

Sin embargo somos conscientes del avance alcanzado en la práctica de la catalogación respecto a la preparación de los registros bibliográficos con el uso de la tecnología. De ahí que los catalogadores puedan estudiar con mayor detalle la creación del catálogo y las listas bibliográficas. Los estudios como los realizados por Tillett, Vellucci, Taniguichi ${ }^{24}$ y la IfLA han servido para mostrar las relaciones que existen entre los atributos de las entidades y nos ayudan a distinguir las tareas básicas que realiza el usuario al consultar el catálogo en línea de la biblioteca. Y nos permiten también operacionalizar el modelo conceptual de las entidades que configuran el universo bibliográfico, y con ello a establecer las relaciones que hay entre las entidades en el nivel básico de la expresión y la lógica de sus partes componentes. Y sin embargo los alcances de dicho modelo están aún en revisión y también se están preparando los medios suficientes para que los catalogadores comprendan, por ejemplo, lo que significa la personificación de la expresión de una obra.

Lo que ocurre en la descripción bibliográfica es que ésta, refiere Minder ${ }^{25}$ siempre ha sido considerada como una actividad que depende de juicios humanos lo que implica en buena medida cierto desconocimiento e ignorancia en el medio disciplinario. De ahí que la descripción bibliográfica se relacione invariablemente con objetivos fundamentales que no la definen en sí misma; pero sí fijan los límites dentro de los cuales se realiza el trabajo profesional y se clarifica su propósito; ciertamente hay que darle un mayor reconocimiento a sus alcances en el nuevo entorno de la organización de la información.

24 Shoici Taniguchi, "Conceptual modeling of component parts of bibliographic resources in cataloging”, en Journal of Documentation, p. 594.

25 Thomas Minder, "On the fundamental theories of bibliographic organization", en American Documentation. 
Finalmente en nuestra discusión sobre los fundamentos de los datos bibliográficos, nos volvemos a remitir al análisis del papel que están desempeñando las tecnologías de la información que, en términos económicos y de la organización de los datos bibliográficos, no están muy lejanas de la creación, el mantenimiento, la compartición y la dependencia de los estándares de los metadatos y el control bibliográfico. En este contexto, el término "económico" se refiere a los costos humanos, tecnológicos y monetarios que se invierten en el control bibliográfico desde un panorama macro y microeconómico; mientras que el término "organización” se refiere a las instituciones depositarias individuales o colectivas, como las bibliotecas, los consorcios o los proveedores de servicios de información, por citar algunos ejemplos. Instituciones que deberán estar en la búsqueda de nuevas formas para la distribución de los datos.

\section{El RETO DE LOS DATOS BIBLIOGRÁFICOS}

DE CARA A LA WEB SEMÁNTICA

Este reto implica que el desarrollo y la aplicación de los datos bibliográficos deben superar las distintas críticas que se han suscitado en el ámbito bibliotecológico y tecnológico.

De un gran optimismo inicial se pasó, en la década de los setenta, a reconocer por ejemplo que los diversos acontecimientos que dieron origen y transformación ${ }^{26}$ al catálogo en tarjeta, luego al catálogo automatizado, y finalmente al catálogo en línea, no puedan crear nuevos diseños debido a que gran parte de las características del catálogo buscan interpretar la semántica del conocimiento a través de las sentencias expresadas en la propia sintaxis de la búsqueda de la información que se hace en el sistema. Quienes han ido más allá, comenzaron a perfilar sistemas integrales de bibliotecas dentro de la iniciativa de la "fuente abierta", ${ }^{27}$ por eso la discusión

26 Naun Chen Chiat, "Next generation OPACs: a cataloging viewpoint", en Cataloging \& Classification Quarterly, p. 330.

27 Op. cit., p. 332. 
sobre el futuro del catálogo emprendió su camino hacia la revisión de los elementos de la Web 2.0 y sus servicios integrados como la Asociación Realmente Simple o RSS (Really Simple Syndication), la vinculación referencial, la personalización y el etiquetado social.

Estas apreciaciones que provinieron del propio campo dejan ver entre las causas principales, aunque en grados diferentes, que el modelo entró en crisis debido a diversas anomalías y a su falta de adecuación a los problemas que pretende resolver. Sin embargo el reposicionamiento del catálogo se debe también al proceso de recolección o la cosecha de los datos (harvesting) que se crea a través de la agregación de registros por medio de un protocolo conocido como Open Archive Initiative o Iniciativa de Archivo Abierto (oIA por sus siglas en inglés).

Pero ese cambio no puede hacerse de manera sencilla para la siguiente generación de catálogos debido a que, como se sabe, gran parte de los catálogos en línea tiene como base un formato legible por máquina (MARC por sus siglas en inglés) monolítico que impide desagregar los datos bibliográficos de manera oportuna.

A pesar de eso hay cambios que se presentan como significativos en el formato bibliográfico, que marcarían nuevas etapas sin que, a nuestro juicio, esto significara una ruptura con el paradigma. Una de esas etapas se refiere a que tal formato está analizando sus posibilidades para transformarse en el nuevo formato MARCXML; es decir en un lenguaje de metadatos que permita optimizar una interfaz que pueda reunir diversos subconjuntos de metadatos.

El otro problema adicional es que los desarrolladores del formato están revisando las diversas estructuras de metadatos que son altamente estructuradas y permitirán modificar la estructura monolítica del formato legible por máquina con el fin de darle consistencia a la elección y aplicación como estándar de contenido.

En la misma línea se encuentran las recomendaciones de Coyle ${ }^{28}$ cuando se refiere a los datos de la biblioteca en el mundo de la web; los modelos de metadatos de la web y la Descripción y Acceso

28 Karen Coyle, "RDA Vocabularies for a twenty-first-century data environment", en Library Technology Report. 
a los Recursos (RDA) en el Marco de Descripción de los Recursos (o Resource Definition Framework, RDF). Y añade que en los últimos años hemos tenido la oportunidad de observar cómo el catálogo ha ido perdiendo vigencia y presencia en el mundo web, lo que se ha debido más que nada a que la comunidad de catalogación no ha querido cambiar y repensar su trabajo. Aun con todo esto los modelos conceptuales de los Requerimientos (RFRB) y el nuevo código de catalogación, Descripción y Acceso a los Recursos (RDA por sus siglas en inglés) están surgiendo como nuevos modelos y reglas dentro de un entorno en el cual el dato es almacenado y administrado por medio de una nueva tecnología más que va creciendo específicamente a través de los estándares de vinculación de datos, los cuales facilitan la interconexión entre los recursos de información. La web proporciona una plataforma que permite hacer tales enlaces entre los recursos y sus resultados.

Los metadatos bibliotecológicos deberán cambiarse hacia el uso de la web si realmente se quiere modificar el significado de la catalogación y también deberá considerarse que los límites creados en la elaboración del registro del catálogo no serán eternos; sin embargo habrá funciones que el usuario del catálogo podrá asumir cuando utilice los datos bibliográficos, lo cual ayudará a explicar las funciones bibliográficas. Pero todo depende del cambio o cambios que decida asumir la comunidad catalogadora.

Es evidente que la incorporación de la tecnología de la información está focalizando la resolución del atraso de la catalogación en asumir una postura distinta y adecuada para un mejor tratamiento de las entidades del universo bibliográfico. De ahí que el sentido que se le otorgue al uso de los datos dependerá de, según Coyle, ${ }^{29}$ cuatro pasos:

1. Diseñar el modelo básico de los datos. Éste deberá corresponder a los señalamientos que se hacen en los alcances de los Requerimientos (RFRB) y las tareas del usuario.

2. Definir de los elementos de los datos. Cada elemento de los datos deberá definirse de acuerdo con ciertos requerimientos que

29 Op cit., p.10 
permitan su descripción dentro de las ontologías y sintaxis de la web semántica.

3. Definir vocabularios. Deberán elaborarse listados simples de términos, pero su definición tendrá que estar lo más cercano al vocabulario determinado por el Identificador Uniforme de Recursos o Uniform Resource Identifier (URL por sus siglas en inglés)

4. Desarrollar reglas de aplicación. Lo que quiere decir que el empleo de reglas de aplicación general no aplica del todo para la web semántica, por lo cual es necesario especificar las restricciones del metadato, como por ejemplo, si el elemento involucrado es obligatorio, mandatario u opcional.

En suma si se está pensando en ingresar en un proceso de cambio en el uso de los datos bibliográficos en el ambiente de la web semántica, debe tomarse en cuenta que no es un gran descubrimiento el que se está haciendo, sino que lo que estamos viviendo es consecuencia de una serie de acontecimientos perfilados para que se camine de la mano de las nuevas expectativas delimitadas por los Requerimientos Funcionales y las nuevas normativas que hemos venido describiendo, y la web semántica. Todo este nuevo marco conceptual y modelado de datos está llegando junto con la tendencia hacia la creación de perfiles para interconectar los recursos de información.

Para finalizar, los datos bibliográficos están tomando una dimensión que indudablemente permite, en teoría, que un usuario, una librería o una biblioteca ocupen los mismos datos que son de interés para satisfacer su necesidades de información. Es por eso que en el mundo de la web semántica la definición de cada elemento del dato está creando una ontología, la cual se expresa en un vocabulario dentro de un dominio particular, situación que le da validez al modelo de los Requerimientos y su incorporación en el nuevo código de catalogación.

Se trata de entender que se han creado nuevas formas de comunicación de los datos bibliográficos, nuevos estilos de trabajo, nuevas maneras de acceder y producir los registros bibliográficos. De ahí que el nuevo código de catalogación establezca una línea 
divisoria entre el registro y la presentación del dato. Comprender lo anterior en toda su dimensión nos permitirá generar prácticas recomendables para el difícil proceso de catalogación actual.

\section{OBRas CONSUltadas}

Carlyle, Allyson (2006), "Understanding FRBR as a Conceptual Model: FRBR and the Bibliographic Universe”, en LRTS, 50, núm. 4.

Coyle, Karen (2007), "Cataloguing rules for the 20th century", en D-Lib. Magazine, vol. 13. núm. 2.

(2010), "RDA Vocabularies for a twenty-first-century data environment”, en Library Technology Reports, [en línea], http:// www.alatechsource.org Consulta: mayo de 2011.

Garrido Arilla, Ma. Rosa (1990), Teoría e historia de la catalogación de documentos, Madrid, Editorial Síntesis.

(2001), "Procedimientos automáticos de creación y transformación de los registros bibliográficos”, en Anales de documentación.

Gredley, E. y A. Hopkinson (1990), Exchanging and bibliographic data: MARC and other international formats, Chicago, American Library Association.

Hagler, Ronald (1997), The bibliographic record and information technology, $3^{\text {rd }}$ ed., Chicago, American Library Association.

Heaney, Michael (1995), "Object-Oriented Cataloging", en Information Technology and Libraries, núm. sept.

International Conference on the Principles and Future Development of AACR (1998), The principles and future of AACR. Proceedings of the International conference on the Principles and Future Development of AACR, Jean Weihs (ed.), Chicago, ALA.

Leazer, Gregory H., "An examination of data elements for bibliographic description: toward a conceptual schema for the US MARC formats”, en LRTS, 32, núm. 2, pp. 188-200.

Madison, Olivia M. A. (2006), "Utilizing the FrBR Framework in Designing User-Focused Digital Content and Access Systems", en LRTS, 50, núm. 1. 
oportunidades y retos en la formación, investigación y aplicación...

Martínez Arellano, Filiberto Felipe y Lina Escalona Ríos (2000) (ed.), Internet, metadatos y acceso a la información en bibliotecas y redes en la era electrónica, México, unAM, CuIB; Infoconsultores.

Minder, Thomas (1960), "The mathematical foundations of bibliographic organization", en American Documentation, vol. XL.

, "On the fundamental theories of bibliographic organization", en American Documentation.

Pisanski, Jan, Maja Žumer y Trond Aalberg (2009), "Frbrisation (frbrización): por un futuro prometedor de las bibliográficas nacionales", en World Library and Information Congress: 75th IFLA General Conference and Council [en línea], http://ifla.org/annual-conference/ifla75/index.htm Consulta: agosto 2009.

Riva, Pat (2007), "Introducing the Functional Requirements for Bibliographic Records and Related IFLA Development", en Bulletin of the American Society for Information Science, núm. Special Section.

Seminar on Bibliographic Records (1992), Proceeding on the Seminar beld in Stockholms, 15-16 august 1990, and sponsored by the IFLA UBCIM Progrmme an the IFLA Division of Bibliographic control, Edited by Ross Bourne, (München: K G Saur).

Svenonius, Elaine (2000), The intellectual foundation of information organization, Cambridge, Mass., The MIT Press.

(1989) (ed.), The conceptual foundations of descriptive cataloging, San Diego, Academic Press.

Taniguchi, Shoici (2003), "Conceptual modeling of component parts of bibliographic resources in cataloging", en Journal of Documentation, vol. 59, núm. 6.

Tillett, Barbara (1991), "A taxonomy of bibliographic relationships", en LRTS, vol. 32, núm. 2.

(2005), "FRBR and Cataloging for the Future", en Cataloging E Classification Quarterly, 39, núm. 3/4. 